\title{
SOCIAL CAPITAL: VECTORS OF DEVELOPMENT OF BEHAVIORAL ECONOMICS
}

Collective monograph

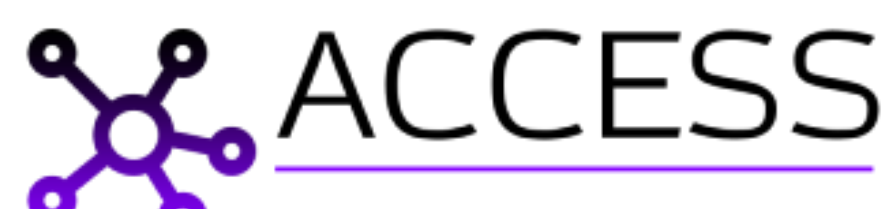

Veliko Tarnovo, 2021 


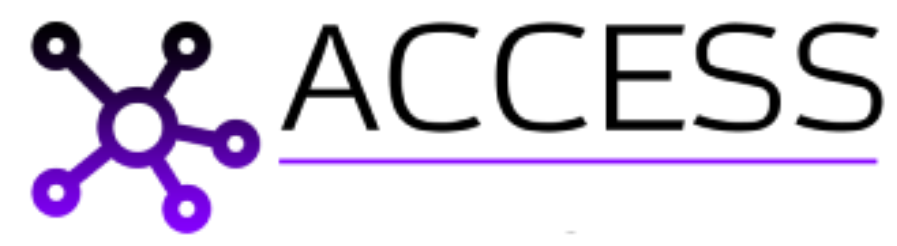

\section{SOCIAL CAPITAL: VECTORS OF DEVELOPMENT OF BEHAVIORAL ECONOMICS}

Collective monograph

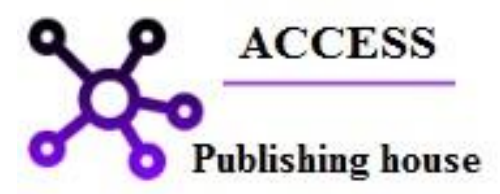




\section{EDITOR:}

Prof. Mariana PETROVA, DSc

St. Cyril and St. Methodius University of Veliko Tarnovo, Bulgaria

\section{SCIENTIFIC BOARD:}

Dzintra ILIŠKO - PhD in Pedagogy, Professor, Daugavpils University, Latvia, Institute of Humanities and Societal Sciences, Centre of Sustainable Education

Elmira Uteubayeva - PhD in Pedagogy, Professor, Academician Y.A. Buketov Karaganda State University, Karaganda, Kazakhstan.

Violeta Marinova - PhD in Pedagogy, Professor, St. Cyril and St. Methodius University of Veliko Tarnovo, Bulgaria.

Ryszard Pukala - PhD, Vice-Rector of Bronislaw Markiewicz State Higher School of Technology and Economics, Poland.

Jelena Badjanova - PhD in Pedagogy, Associate Professor, Department of Pedagogy and Psychology, Faculty of Education and Management, Daugavpils University, Latvia

Ludmila Stemplewska - PhD, Professor, Vistula Academy of Finance and Business in Warsaw, Poland.

Jelena Lukjanova - PhD, Associate Professor, ISMA University, Riga, Latvia.

\section{ISBN 978-619-91511-4-3}

Social capital: vectors of development of behavioral economics: collective monograph / Editor: Mariana Petrova. Veliko Tarnovo, Bulgaria: ACCESS Press Publishing house, 2021. 184 p.

\section{https://doi.org/10.46656/book.2021.social.capital}

(C) Editor: Mariana Petrova, 2021

(C) Collective authors, 2021

(C) Publisher: ACCESS Press Publishing house, 2021

Email: office@ access-bg.org

http://www.access-bg.org

Authors are responsible for the content and accuracy. The proceedings have not been amended or proofread.

Published under the terms of the Creative Commons CC BY- NC 4.0 License
(C) ACCESS Press Publishing house, 2021

(C) Authors, 2021 


\section{CONTENTS}

EImira UTEUBAYEVA, Tatyana KOKHANOVER

THE APPROACHES TO TEACHING ENGLISH TO PRESCHOOL CHILDREN AND THEIR EFFICIENCY

Larysa KAPINUS, Natalia SKRYHUN, Kateryna SEMENENKO, Svitlana 18 KOLODIUK

CONSEPTUALISATION OF CATEGORY «BEHAVIOR OF THE ENTERPRISE» IN ECONOMIC THEORY

Tetiana NEBOHA, Svetlana SUPRUNENKO

ECONOMIC RELATIONS DEVELOPMENT INFLUENCED BY MODERN INFOCOMMUNICATIONS IN TERMS OF ECONOMIC AND SOCIAL TRANSFORMATION

Oleksandra OVCHYNNYKOVA

SOCIAL CAPITAL SYSTEM AS A DEVELOPMENT FACTOR AND BEHAVIOURAL ECONOMY CONDITION

Oksana YASKAL, Ihor YASKAL, Kristina VOLOVIDNYK, Oksana

\section{LOZIAK}

ECONOMIC AND PSYCHOLOGICAL APPROACHES FOR CUSTOMER TYPOLOGY: CASE OF UKRAINIAN REGIONAL RETAIL MARKET

Lev VLASENKO

CULTURAL COMPLEMENTARITY INDEX AND ITS APPLICATION IN BILATERAL TRADE ANALYSIS, A CASE OF UKRAINE

Svitlana BEREZINA, Vladyslava KONOTOPETS

PERSPECTIVES ON THE IMPACT OF MIGRATION RISKS ON THE STATE ECONOMY

Olga OSTAPENKO

ESTIMATION OF TENDENCIES OF TRANSFORMING THE ENERGY SECTORS OF WORLD, EUROPEAN UNION AND UKRAINE IN THE PERSPECTIVE TO 2050 WITH USING THE RENEWABLE ENERGY SOURCES IN THE CONCEPT OF SUSTAINABLE DEVELOPMENT 
Oleksandra LAKTIONOVA, Iryna SEDIKOVA, Viktor KOVAL, Sergey RADUKANOV

CONCEPTUAL APPROACHES TO FINANCIAL RISK MANAGEMENT OF THE COMPANY BASED ON THE THEORY OF SUSTAINABILITY

Oksana KOSIUK

RELEVANT INTERRELATIONSHIPS BETWEEN SCIENCE AND MASS COMMUNICATION

Natalia GERASIMOVA, Inna GERASYMOVA, Svitlana DMYTRYUK

STUDENTS 'ADAPTATION TO LEARNING AS A PSYCHOLOGICAL PROBLEM

Maria KALENYCHENKO

THE STRUCTURAL AND SEMANTIC CHARACTERISTICS OF SINGLE-

SYLLABLE IMPERSONAL SENTENCES IN THE CZECH LANGUAGE 


\title{
THE APPROACHES TO TEACHING ENGLISH TO PRESCHOOL CHILDREN AND THEIR EFFICIENCY
}

\author{
Elmira Uteubayeva ${ }^{1}$, Tatyana Kokhanover ${ }^{2}$ \\ ${ }^{1,2}$ E.A.Buktov Karaganda University, Karaganda, Kazakhstan \\ ORCID ID : 0000-0002-1648-114X
}

\begin{abstract}
The article presents the theoretical substantiation and the results of experimental testing of the technology we have created for teaching preschoolers to speak foreign language and proves its effectiveness. The effectiveness of teaching preschoolers a foreign language, as noted by experts, is achieved with an optimal ratio of the following features - the personality of the child: whether he is slow or mobile, is he endowed with a sense of humor, what type of memorization he has, what is his age, range of interests, learns better in a team or individually, what are his achievements in his native language, what is his temperament, is he confident in his abilities, is inherent whether he is optimistic; personality of the teacher: good command of a foreign language, deep knowledge of the native language of students, acting skills, what types of activity he prefers; teaching methods: how do different types of educational speech activity correlate in the classroom, what are the types and composition of teaching aids, how much teaching material and in what ways and methods it is supposed to convey it to students, in what portions, at what pace, for how long, how the relationship will be built old and new material; support for learning the language by the family: do the parents know the target language, can they help the child in learning, are there books, films, recordings of songs in the target language at home, are they planning trips to the country of the target language. Based on the theoretical and psychological characteristics of teaching foreign languages to preschoolers, a technology for teaching preschoolers foreign language oral speech was developed, including methodological recommendations for organizing teaching English to preschoolers, a set of didactic materials.
\end{abstract}

\section{INTRODUCTION}

Among the recognized scientific and pedagogical community of Bulgaria, Poland, Latvia, Ukraine, Poland, Kazakhstan conceptual trends in preschool education have become the subject of numerous scientific and pedagogical studies [Diachok et al, 2020; Arsova, 2021A; Arsova, 2021B; Ivanchuk et al, 2020; Arsova, 2020; Petrova, Popova, Dejniak, 2020; Valdmane et al, 2020; Zhetpisbayeva \& Shelestova, 2016].

At the initial stage of the development of our proposed technology for teaching the elementary level of communicative competence, a survey (questionnaire) was conducted of teachers teaching English in preschool institutions and a control lesson diagnosing the formation of language communicative competence in students in accordance with the expected results presented in the State Curriculum.

Analysis of the survey data showed that the introduction of early preschool English language teaching is complicated by a number of circumstances, some of which are:

- an acute shortage of teaching staff able to work in the new conditions, namely the lack of teachers who know the methodology of early teaching of the English language;-

- lack of modern didactic materials (programs, teaching materials, dictionaries, guidelines, guidelines, etc.).-

These provisions determine the objective need for advanced training and the creation of an optimal model of professional retraining of foreign language teachers for work at an early stage of teaching English.

In accordance with the didactic conditions necessary for the successful implementation of the elementary level of communicative competence at the preschool stage and taking into account the 
requirements for the elementary level of communicative competence, methodological recommendations were developed for organizing the educational process in English in preschool institutions and a set of didactic materials.

An analysis was carried out, the existing visual material and technical teaching aids were systematized. As a result, the following were selected and developed:

- toy of the main character SMARTY;

- the necessary thematic cards for practicing lexico-grammatical material;

- posters for "talking walls";

- poems and songs were systematized, taking into account the principle of the sequence of the presentation of the material;

- materials were prepared to check the learning outcomes.

The final part was characterized by active attendance at classes in order to diagnose children at the level of formation of the elementary level of communicative competence.

103 people took part in the formative experiment on the basis of 3 institutions, a nurserygarden "Solnyshko", a nursery-garden "Akku".

\section{THEORETICAL AND METHODOLOGICAL BASIS OF THE PRESCHOOL TEACHING}

The experiment was carried out in a natural setting in English classes. The specificity of each separate period of preschool age involves the use of its own technology. Our technology was developed for children 5-6 years old. In the process of experimental learning, the age of most of the children reached 5-6 years. 50 children were also interviewed.

In the learning process, both subject visualization, the importance of which is emphasized by experts in preschool education, and meaningful generalization inherent in developmental education were widely used. The results of scientific research proving the effectiveness of teaching through the activation of all types of student activities were also taken into account by us when creating a technology aimed at teaching preschoolers foreign language speech skills.

At this stage, the classes were built according to the developed set of didactic materials and methodological recommendations for organizing the educational process in English in preschool institutions. The material is mainly game tasks that are used in the process of teaching a foreign language. In addition to educational purposes, exercises also have a cognitive, developmental and educational role. Below we present examples of exercises for the development of attention, which, according to experts, is very important in working with preschoolers.

\section{ATTENTION DEVELOPMENT EXERCISE}

On the wall there are colorful letters of the English alphabet or cards with pictures of the words being studied. Students look at their location on the wall. The teacher then removes one or more letters or cards and asks the students to say what was removed. You can play around with this situation depending on the vocabulary being studied. For example, when studying animals, the protagonist Smarty can invite someone to visit or another place and the children must guess who.

Along with games for attention, when teaching foreign language speech, we used guess games that contribute to the development of mental activity.

\section{EXERCISE FOR THE DEVELOPMENT OF THINKING ACTIVITIES}

On the talking wall is the figure of the protagonist Smarty and the children, using the garments and the season, must dress him. The game can use various cards for practicing both vocabulary and grammatical structures, "has / have got", "there is / there are", etc. 


\section{PHONETIC EXERCISES}

- To train short and long sounds [i], a list of things and products is compiled, in the name of which these sounds are present. Some students should choose products with a short sound in an imaginary store, others with a long sound.

- Uses the same idea, but offers vocabulary on different topics.

In accordance with the logic of the study, the period of the formative experiment ended with diagnostics. Systematizing the results of the trainees' activity, we used the method of statistics and mathematical data processing.

At the final stage of the study, based on the results of the experiment, methodological recommendations were developed for organizing the educational process in English in preschool institutions.

It should be emphasized that our technology was created to teach preschoolers such types of speech as speaking (oral form of external speech) and listening. We consider it necessary to turn to some theoretical provisions, which were the methodological basis of our research at the stage of the formative experiment.

In accordance with the generally accepted classification of speech, the oral form of speech is

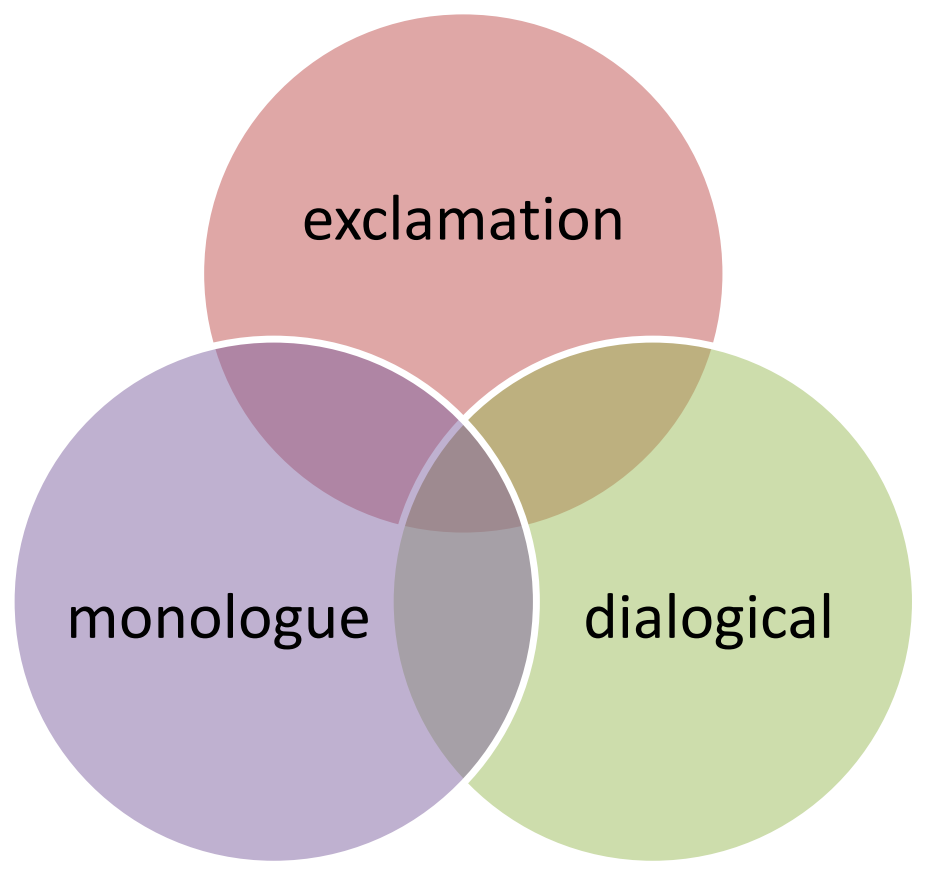

Considering the requirements for speech formation, we have identified the following tasks of our technology:

- studying vocabulary,

- formation of the grammatical aspect of speech,

- work on pronunciation, rhythm and intonation.

The result of performing these tasks should be expressed, in our opinion, in the communicative function of a foreign (English) language. acquisition:

In our research, we took into account the provisions of various theories of language Skinner)

- psychological theory of speech activity (A. A. Leontiev), behaviorist (D. Watson, B.

- biological (N. Chomsky, McNeil)

- learning theory. 
The most popular in the world are behavioral and biological theories. According to the supporters of the behaviorist theory, the child learns to speak, focusing on the examples of adults. Imitation and imitation are of the utmost importance.

The adherents of the biological theory prove the innate ability to master the language. Learning theorists argue that children involuntarily "extract" general rules from what they hear and then apply them to their own speech.

We, however, adhere to the point of view of the majority of domestic scientists who admit that the formation of oral speech is still an insufficiently disclosed process, complex in its mechanism and rather lengthy, and that in the process of mastering speech at once all the factors presented in the above theories are the social environment. , the child's own experience of life and biological inclinations - to a certain extent, affect the development of the child's speech. In the course of the development of speech, the child does a tremendous amount of work on orientation in the language, on the coordination of articulatory-pronouncing actions with the auditory images received from adults as samples.

The process of mastering a foreign language by children is greatly influenced by the level of development of their native speech. A number of scientists note both the necessity and the inevitability of reliance on the native language when teaching a foreign language. In addition, the main cognitive role belongs to the native language. Only the categories acquired during the primary language development pass into the second language.

Mastering native and foreign language is based on psychophysical processes. The interdependence of thinking, mental processes and speech activity is noted both in domestic and foreign studies. In our work, we took into account both the theory of J. Piaget, which considers language as a reflection of thinking, and the concept of L. S. Vygotsky (Vygotsky, 1997), in accordance with which thinking and speech are first formed as independent systems, and then they are combined, raising thinking to a higher level. development.

Given these ideas, we can conclude that speech is more developed with more developed mental abilities, on the one hand, and on the other hand, language has a developing effect on the mental abilities of the child.

The effectiveness of the child's mastery of foreign language speech depends on the mental abilities and personality type. Therefore, when forming groups for training, we took into account the data of research of personality types by N.A.Menchinskaya and V.A.Krutetsky.

As for the child's ability, the child's ability to memorize is of paramount importance in mastering a foreign language. We relied on the thesis that memorization efficiency is associated with:

- associativity,

- game,

- own activities.

In our research, we relied on the statements of domestic and foreign scientists about memory as a property of the nervous system, which works differently in different people. When teaching children, we used all types of memory (auditory, visual, motor), as well as its mixed types: visualmotor, visual-auditory, etc. At the same time, taking into account the statement of scientists that memorization can be improved with the help of exercises and education, we have developed a series of exercises for our sessions that serve this purpose. When developing the exercises, we used the following mnemonic techniques recommended by specialists in the field of teaching foreign languages:

1. imagination (coming up with stories with the inclusion of an element for memorization);

2. exaggeration (the size, shape, sound of all mental images is exaggerated);

3. humor (the funnier the images, the better they are remembered);

4. movement (makes it easier for the brain to remember.

The effectiveness of this technique is associated with the work of the left and right hemispheres of the brain. Of course, in addition to developing, our exercises have teaching and educational purposes. When developing the exercises, we took into account the principle of sensitivity or the leading type of activity. For preschoolers, play is the leading activity. Therefore, the exercises 
developed by us are of a play nature. L.A. Wenger and A.L. Wenger distinguish the following types of games:

- plot and role-playing (for the sake of the process, not the result),

- didactic (for the sake of the result),

- outdoor games.

L. A. Venger defines "didactic games and playing techniques in the formulation of educational tasks as play forms of teaching." Let us illustrate the application of didactic games in our technology with the following example. As a teaching material when performing some exercises, we used the board game "Lotto in four languages" by the author A. I. Kreshchanovskaya. The set of pictures offered in the game creates an excellent opportunity to use them in order to develop visual and visual-auditory memory. The possibility of active and regular use of the game for educational purposes is due to the variety of topics on which the visual material is organized.

While studying the topic "My Home", we chose a picture that shows a room with typical elements (window, door, etc.) and typical pieces of furniture. The picture itself is a large image of a room in the center of the picture, along the perimeter of which there are 8 small pictures depicting objects available in the large picture (ceiling, chair, door, table, wardrobe, bed, window, floor). Small pictures have duplicates, representing a card. Exercise-game based on one picture can be modified from one lesson to another.

Based on the principles of consistency, systematicity and strength of mastery of speech material, the teacher can perform the work either at his own discretion in relation to the existing conditions, or in the following order. The exercises are aimed at mastering the educational speech material on the topic "My home". The sequence of exercises is described below.

The teacher covers one of the small objects with the back side of the card with the image of the same object. Children should remember which object is closed and name it in English.

This type of work provides an excellent opportunity for an educational moment. The teacher may ask the children to raise their hand if they want to answer. Alternatively, the teacher may allow the children to shout out their answer once. The one whose answer was first and correct is the winner. However, in the second case, the teacher must precede his permission to shout out with the words: "You know that you cannot shout out answers in class, but now it will even have to be done." Experience shows that the permitted "no" loses its attractiveness, and the disciplinary-organizational atmosphere of the lesson is not disturbed in this case.

Gradually, the teacher closes all the small pictures. Job options:

a) the children take turns to guess what is hidden behind one of the cards, naming the subject in English. As a reward, children receive a card with an object, the name of which they have remembered and the location of which they guessed in the picture;

b) one child should try to remember as many words as possible, indicating the location of objects in closed small pictures to which these words refer.

At the end of the game, the number of guessed symbols is counted. The next child tries to complete the same task, etc. For each player, the number of guessed pictures is counted. The winner is the one who guessed as many pictures as possible.

On the same material, visual and auditory memory can be trained using the following exercise, presented in stages:

1. Choral repetition of the English names of the objects in the picture, using the speech pattern given by the teacher.

2. Two children are called. The teacher calls the word in English - children should repeat this word as soon as possible and show the desired object in

a) a small picture; b) a big picture.

The winner is the one who is more likely to show the named item. Similar exercises can be performed using other visual material.

Visual-auditory (long-term) memory develops during the next task. The teacher invites the children to look at two familiar pictures on the theme "Winter", according to which the children had 
previously composed and reproduced the story. "There are two pictures, but only one is needed," the teacher says and asks the children to choose the one to which the sentence fits (The teacher pronounces the sentence.). The survey can be frontal, or two people can be called to compete with each other.

The final part of the experiment was preceded by an experiment with preschool children in order to form their elementary level of communicative competence. During this time, material was collected on the basis of attendance at English classes in children's institutions where the experiment was taking place.

The ascertaining experiment was carried out in order to identify the initial level of proficiency in a foreign language speech activity and was a diagnosis of the speech skills of children in the English language. In view of the fact that the problem of teaching foreign language speech for preschool children is not sufficiently scientifically developed, we were faced with the task of developing criteria for assessing the level of development of speech skills in teaching preschool children. At the same time, the experience of diagnosing children used in examining the level of native speech was taken into account.

In addition to the processing of already existing tests, we have defined criteria for assessing the level of proficiency in a foreign language for children of 4-7 years of age, including the following speech skills:

- choral reproduction of speech samples;

- individual reproduction of speech samples;

- phonetic correctness of speech and correct articulation;

- correct performance of tasks with visual support;

- the ability to isolate words from the flow of speech;

- adequate use of lexical and grammatical material in a natural setting in everyday communication;

- manifestation of unprepared speech.

The criteria were determined on the basis of: observation of children in the older groups of preschool institutions; a survey on this issue of teachers of foreign languages.

In the process of the experimental examination, special attention was paid to the phonetic aspect in the speech of children. "The sensitivity of preschool age towards another (non-native) language is manifested primarily in articulation. Pronunciation at this age is learned flawlessly. Preschoolers have no prejudices regarding the second language - they are not afraid to make a mistake, they perceive communication with people different from themselves without prejudice, they are not disappointed in their capabilities, they do not realize all the potential problems of learning, "the teachers rightly note.

In our experiment, during the examination, children performed a task consisting in a simple repetition of individual words, as well as phrases, which for the most part were stanzas from rhymes and counting rhymes in English. Particular attention was paid to checking the phonetic correctness of pronunciation of specific English sounds (that, mother; three; long, morning; what, window). The result showed that all the specific sounds of the English language were replaced by all children with Russian sounds.

When examining choral skills, the following results were revealed: children could not start reproducing a poem without prompting from the teacher; in most of the surveyed groups, choral reproduction was carried out only with the speech accompaniment of the teacher.

The knowledge of the passed lexical units without visual support by means of translation from English into Russian was tested during the last examination in the ascertaining experiment, 26 children of 6 years old were subjected to. As a result, out of 15 suggested words on the topics "Toys" and "My family" (cat, dog, fox, bear, cock, cow, mother, father, sister, brother, family, boy, girl, children, hands) we were able to translate:

3 words - 4 people;

2 words - 7 people;

1 word - 12 people; 
2 people could not translate any of the suggested words.

The memory test was carried out both in the Russian version using the Wenger test, and in the English version, which tested the child's ability to memorize a poem during one lesson. The following rhyme was suggested for learning:

Good morning, good morning, good morning to you.

Good morning, good morning, I'm glad to see you.

On the one hand, different memorization abilities in Russian and English were revealed. With good Russian-language memory, many children were unable to reproduce the required number of repetitions in a quatrain. On the other hand, it has been found that most children cannot reproduce speech patterns phonetically correctly. Tasks to identify the level of memory allow us to draw the following conclusions: the older the preschooler, the better his memory. However, it should be remembered that the memory of preschoolers is not able to retain the material learned for a long time.

This is proved by the practice of diagnosing children 5-7 years old at the end of a three-month summer vacation. Not a single examined child could reproduce all the previously studied material on his own. $40 \%$ of children said that they were familiar with the material proposed for reproduction, but they themselves could not reproduce it. During the survey, it was found that of these $40 \%$, only a third of the children were fully familiar with last year's material. For the rest of the children, memorization was fragmentary. $60 \%$ of children said that they did not remember the material offered to them at all and could not recognize the vocabulary and quatrains offered to them.

The memory of preschoolers is also fragile in relation to the material studied in a short period of time. The test showed that, for example, poems studied specifically for a certain holiday for a short period of time are forgotten by children very quickly. So, already three weeks after the New Year holidays, 6 out of 20 children 5-6 years old said that they did not remember at all that they had ever learned the poems that the teacher was talking about. Another 7 people said that the verses were familiar to them, but they could not read them, because they did not remember the words. It was about two poems learned for the New Year during two weeks of daily classes. Before the New Year, all children could read these verses on their own or with a little hint from the teacher. We used the obtained conclusions when creating our technology.

The level of memory development is directly proportional to the level of skills and abilities of adequate translation. Therefore, preschoolers of different ages have different levels of skills and abilities. In children of 4 years old, the somatization of foreign words is very unstable - when translating words, words of the same semantic field can be named, but they are not a translation of the desired word. For example, when asked to show what is called a "nose" in English, a child may show an ear, eye, or mouth. If a 4-year-old child has to translate the word "winter", then often the answer can be "spring", "summer", "season".

We took these conclusions into account when developing diagnostic tests for preschool children of different age periods. What can be considered sufficient for children 4 years old, for children 6 years old may be an indicator of a low level.

Testing children for the ability to adequately translate words revealed a weak use of associative interlanguage connections by children. Thus, seven children out of 21 examined in the group made a mistake in the translation of the word "orange", which even in its sound resembles the Russian word "orange".

Testing the children's knowledge of the colors of the rainbow using a translation task revealed the following patterns. $60 \%$ of the surveyed children were able to name the colors of the rainbow consecutively in English and Russian. However, only 30\% of the children were able to give an adequate translation of the words denoting color, proposed at random. By offering children to translate words from Russian into English, and then the same words from English into Russian, we hypothesized that translation into their native Russian language would be easier for children. The test did not confirm our hypothesis. In both versions of the translation, approximately the same number of mistakes were made. Only in isolated cases was translation into Russian easier.

Objectives with visual support included the following types: 
a) name the actions performed by the six bears depicted in the book. Children confused verbs or could not remember a verb in English at all;

b) show in the picture with bears performing various actions, a bear, which includes the teacher's remarks like "I can walk (jump, sit)". Despite the fact that the children happily performed these movements under the command of the teacher and together with the teachers, there was not a single child who would point to all the corresponding pictures. For the most part, the children, pointing to the picture, looked inquiringly at the teacher, expecting his reaction.

c) the next task, connected with visual support, consisted of dubbing a familiar cartoon with the sound turned off. This task turned out to be impossible.

In the ascertaining experiment, the ability of children to isolate a word from a stream of speech was tested. The task of isolating a word from a stream of words leads, in our opinion, to the development of comprehension of the language. The cliche method widely used in teaching children, from our point of view, is more automatic than a meaningful way of memorizing. The ability to isolate a word is associated with the ability to divide sentences and phrases into separate words.

The check was carried out using the following techniques. For example, children are asked the question "How should polite people greet each other in the morning?" When the expected answer is "Good morning," the teacher shows a picture of morning and asks what time of day is shown. The children gave the correct answer in Russian "Morning", but in English some of the children answered "Good morning" instead of the correct answer "Morning", and most of the children could not give any answer at all.

This confirms the observations of the Methodists that for children a foreign language phrase is an inseparable linguistic unit, and supports their belief that it is necessary to take it for granted. However, we are convinced that knowledge of isolated words contributes to the comprehension of the material and accelerates the process of independent use of the language for communicative purposes.

The ascertaining stage of our experiment showed that the majority of children trained in other technologies did not have the necessary speech knowledge, skills and abilities that would indicate the successful mastery of foreign language speech activity by children. We see the reasons for this:

- the absence of sufficient generalized theoretical and practical experience in teaching preschool children foreign language speech;

- ignoring the psychological aspect of teaching children a foreign language; insufficient training of teachers;

- in the absence of developed programs with scientifically grounded recommendations on the content and use of educational material, on the form of conducting classes, on the preparation of an optimal schedule.

The technologies used in the groups studied by us had the following disadvantages:

- the phonetic aspect was neglected;

- a small number of hours were allocated for English classes;

- there was no system, sequence, algorithm in the presentation of material and in the organization of the educational process;

- child psychology was not always taken into account;

- there was no individual approach;

- the personality-activity approach was poorly used;

- there were no tasks aimed at enhancing and intensifying the activities of students;

- there was excessive language care, expressed in the constant pronunciation of the speech material by the teacher with the children;

- there was a lack of sufficient subject visualization (especially when teaching 6-7 years old in the first grades of school);

- the main focus was on rote memorization;

- there was a weak effect on all senses;

- the method of creating a problem situation was not used; 
- the combination of all types of activity (English combined with drawing, physical education, music) was not used enough.

The conclusions made on the basis of the ascertaining experiment were taken into account by us when creating the author's technology for teaching preschool children a foreign language speech activity. Starting to teach children in the control and experimental groups, where the initial level was taken by us as zero, we identified for ourselves the directions of training, which were justified by the need to form the skills and abilities we have defined in the trainees.

\section{PROFICIENCY OF FOREIGN LANGUAGE SPEECH ACTIVITY}

The observation made it possible to identify three levels of criteria for assessing the proficiency of a foreign language speech activity:

Level I, assuming mastery of foreign language speech activity in the form of choral reproduction of speech patterns and correct articulation;

Level II, determined by the ability to isolate words from the stream of foreign language speech, individual reproduction of samples of foreign language speech and the correct performance of the task with visual support;

Level III, including the skills and abilities of adequate two-way translation, unprepared speech activity in a new environment, adequate use of lexical and grammatical material in a natural setting. However, as shown by diagnostics, the skills and abilities of children within a particular type of foreign language speech activity also differed in their level. This led to the conclusion that it is necessary to develop a diagnostic apparatus for assessing skills and abilities within each type of foreign language speech activity.

The results obtained at the stage of the ascertaining experiment directly affected the formation of the goals of experimental learning, the choice of material and the organization of the educational process, prompted the candidate to make adjustments to the diagnostic procedure, which involves examining children in accordance with the criteria we have defined. The development of diagnostic tests was one of the priority problems solved at the stage of the formative experiment. The essence, content, forms and results of the formative experiment are presented in the next paragraph. 
Creating the experimental technology, we relied on the proposition that the technology of teaching speech activity is a procedural part of the pedagogical system for the formation of educational speech activity. Its implementation was carried out in the process of a formative experiment in the form of the following technological chain:

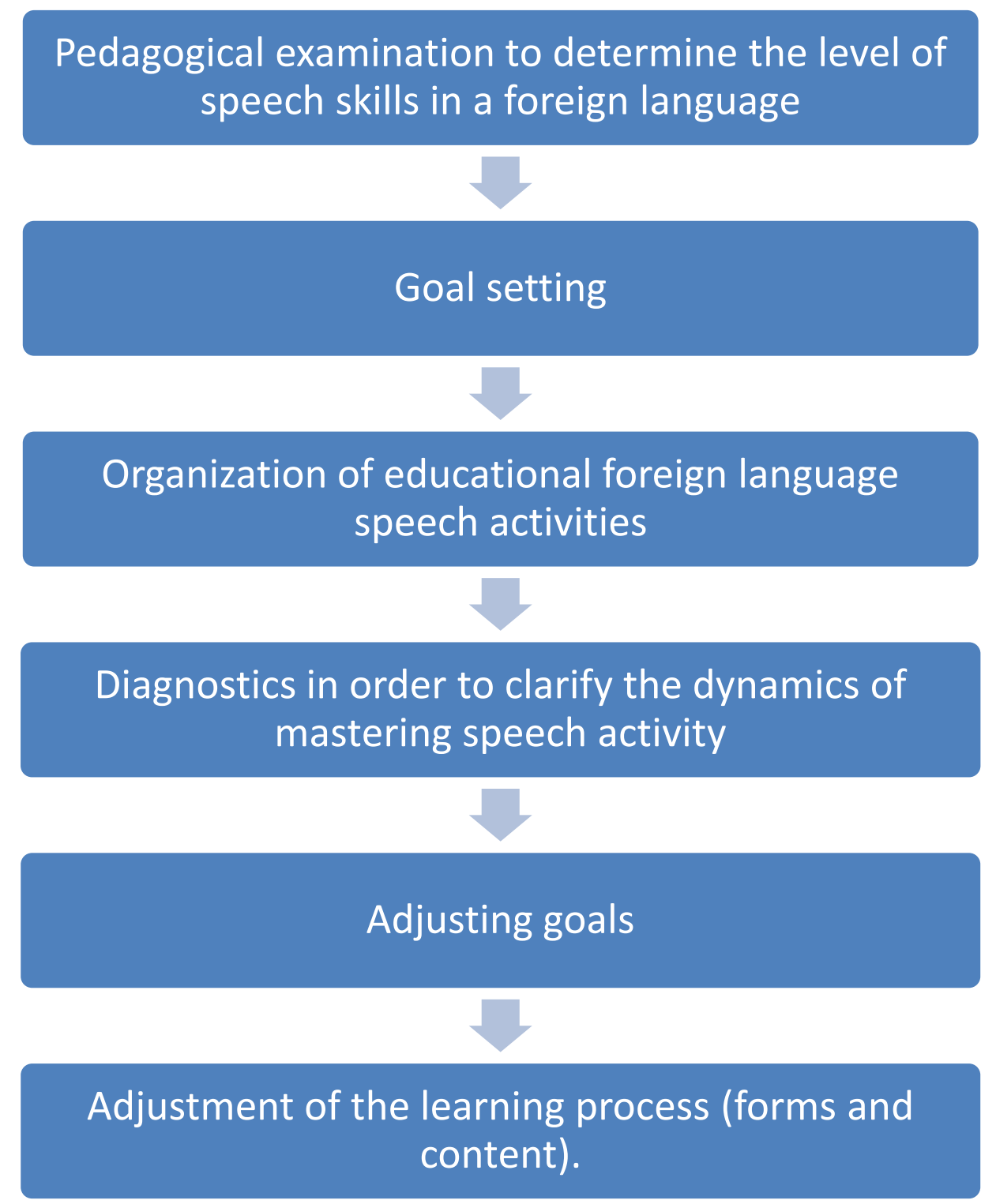

From our point of view, the procedural component is only a constituent element of the technology itself. While developing the technology of teaching foreign language speech activity of preschoolers, we considered it as an interconnected and interdependent complex of conceptual, content and procedural components, which is clearly shown in the diagram on the next page.

- The conceptual component was based on the theoretical foundations presented in the dissertation by the ideas of personality-oriented education, the theory of foreign language speech activity, and the teaching of designing teaching technologies.

- The content component of the proposed technology included the author's program, involving the study of the following topics:

- Acquaintance

- $\mathrm{ABC}$

- Country of the target language

- Toys 
-Pets

- Class

- Room

-I can

- Winter

- Animals

-A family

-Kindergarten

- Food

-Birthday

- Seasons

- Clothing

-Playground

\section{TECHNOLOGY OF TEACHING FOREIGN LANGUAGE SPEECH ACTIVITY FOR}

\section{PRESCHOOLERS}

Conceptual component

Theoretical foundations of technology Target setting speech development of preschoolers General pedagogical principles Particular methodological principles (communicative speech focus; taking into account the peculiarities of the native language; the dominant role of exercise; combining language training with

language practice; approximation of foreign language speech activity; learning based on a speech pattern; oral lead)

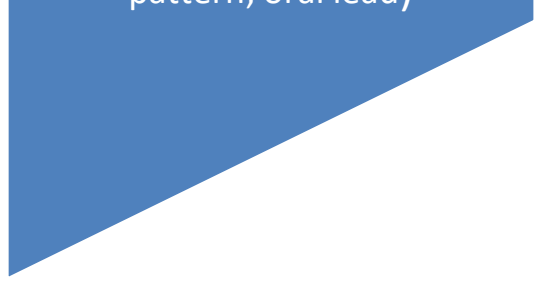

Pithy component Theoretical foundations of technology Target setting - speech development of preschoolers General pedagogical principles Particular methodological principles (communicative speech focus; taking into account the peculiarities of the native language; the dominant role of exercise; combining language training with language practice; approximation of foreign language speech activity; learning based on a speech pattern; verbal advance

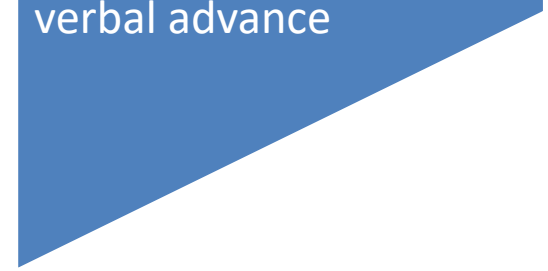

Procedural component an integrated lesson with elements of drawing, music, physical education; the game; dramatization; matinee; entertainment) Methods (speech exercises; educational dialogue, monologue; choral speech activity; work in pairs, groups) Visual and technical teaching aids (printed material, teaching aids, toys, audio and video cassettes) Development of criteria Diagnostics of the levels of foreign language speech activity of preschool children

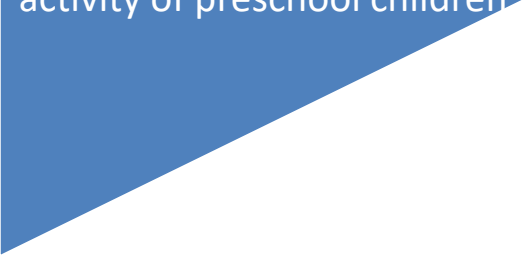

The purpose of the technology used was the development of reproductive speech skills and the transition to productive speech. In working with children, a moment is very important. relating to cognitive activity. A child who has no idea about a particular phenomenon or object is not able to 
perceive information about it in a foreign language. The technology we have applied is based on the activation of all types of activities in teaching children foreign language speech, on expanding the child's horizons, on enriching his personal experience, on his intellectual, emotional and creative development.

\section{CONCLUSIONS}

The proposed technology is based on the principles of consistency, consistency, strength, clarity, scientific nature, and the connection between theory and practice. The lesson-less algorithm in the process of experimental learning can be represented as follows:

1) creating motivation,

2) semantisation of words using traditional and non-traditional methods and techniques,

3) game for consolidation,

4) learning a poem or song on the topic under study with accompanying movements,

5) watching a video (listening to audio) containing lesson material,

6) dubbing the cartoon with the sound off,

7) dramatization of cartoon episodes or staging a fairy tale based on the studied material in the form of a puppet or drama performance.

The core point in our technology is variable multiple repetition of the material. So, in our work we used theatrical activity, during which the child takes on the role of a character. The dramatization game was carried out under the guidance of a teacher. Director-type games were organized by the children themselves. From the point of view of some teachers, it is unorganized, spontaneous play that has the right to be called a game.

We do not agree with this statement, but in every possible way we welcome children's initiative in organizing our own activities. In this situation, the physical accessibility of the play material should take place, which implies the organization of the play space at the level of children's growth and the constant availability of material in the group. We put this principle into practice. Children with pleasure became actors, changed roles, helped each other. In addition to the main task of developing speech foreign language activity, this type of lesson solved the problem of developing creative, organizational abilities, and also contributed to the development of interpersonal communication skills.

The implementation of the technology we propose requires a significant number of poems and songs on the topics studied, a sufficient volume of handouts, a variety of cartoons with different plots, but a similar lexical set, visual aids aimed at a solid assimilation of lexico-grammatical material.

\section{REFERENCE:}

Arsova, D. Developing of the elementary school students `skills in a digital world// Procedings XIII International scientific conference "Innovations in Technology and Education", Kuzbass State Technical University, 26 march 2020.: Belovo, Russia /- Vol. 4., p. 55-60. ISBN 978-5-00137-0659

Arsova, D. (2021A). The role of e-books in the digitalisation process in primary school. Procedings XIV International scientific conference "Innovations in Technology and Education", Kuzbass State Technical University, 26 march 2021.: Belovo, Russia /- Vol. 4

Arsova, D. (2021B). Skills and competencies of the new generation of students to work with digital devices. Procedings XIV International scientific conference "Innovations in Technology and Education", Kuzbass State Technical University, 26 march 2021.: Belovo, Russia.

Galskova N. D. \& Gez N.I. (2006). Teoriia obucheniia inostrannym iazykam. Lingvodidaktika i metodika [Theory of teaching foreign languages. Linguodidactics and methods]. M.: Izdatelskii tsentr «Akademiia».

Gomza S.H. (2011) Angliiskii dlya doshkolnikov. Minsk.

Diachok, N., Chernukha, N., Tokaruk, L., Udovenko, I., Petrova, M. 2020. Practical-oriented concept as a principle of professional education of the future professionals. International Journal of Higher Education, Vol. 9, No. 4, August 2020, pp.272-282, https://doi.org/10.5430/ijhe.v9n4p272 
Ivanchuk, S., Voznik, A., Dronova, O., Girenko, N., Arsova, D. (2020). Preparation of Future Preschool Education Specialists for the Use of Modern Educational Technologies. International Journal of Higher Education, Vol. 9, No. 5, August 2020, pp.28-35, https://doi.org/10.5430/ijhe.v9n5P28

Nakatani, Y. (2012). Exploring the Implementation of the CEFR in Asian Contexts: Focus on Communication Strategies. Procedia.

Olovnikova N.G. (2001) Inostranniy yazik v detskom sadu. Minsk.

Petrova, M.; Popova, L.; Dejniak, D. (2020). Children's University activities as implementation of the third mission of higher education institution. Strategies for Policy in Science and Education, Volume: 28, Issue: 2, Pages 161-171

Valdmane, L., Zariņa, S., Iliško, D., Badjanova, J., Petrova, M. (2020). Empowering of digital and media literacy of primary school teachers in Latvia. EDULEARN20, Proceedings of EDULEARN20 Conference 6th-7th July 2020, ISSN: 2340-1117, pp.4022-4029, Publisher: IATED. DOI:10.21125/edulearn.2020

Vygotsky L.S. (1997) Voprosy detskoy psykhologii. Moscow

Zhetpisbayeva B. A., Shelestova T. Yu. (2016). Empiricheskiye predposylki rannego obucheniya angliyskomu yazyku $\mathrm{v}$ shkolakh Kazakhstana $\mathrm{v}$ ramkakh sovremennoy praktiki trekh"yazychnogo obrazovaniya [Empirical preconditions for early teaching of English in schools of Kazakhstan in the framework of modern practice of trilingual education]. Aktual'nyye problemy filologii i metodiki prepodavaniya inostrannykh yazykov - Actual problems of philology and methods of teaching foreign languages. № 10, 153-162 [in Russian]. 


\title{
CONSEPTUALISATION OF CATEGORY «BEHAVIOR OF THE ENTERPRISE» IN ECONOMIC THEORY
}

\author{
Larysa Kapinus $^{1}$, Natalia Skryhun², Kateryna Semenenko ${ }^{3}$, Svitlana Kolodiuk ${ }^{4}$ \\ ${ }^{1}$ National University of Food Technologies, Kyiv, Ukraine \\ ${ }^{2}$ National University of Food Technologies, Kyiv, Ukraine \\ ${ }^{3}$ National University of Food Technologies, Kyiv, Ukraine \\ ${ }^{4}$ National University of Food Technologies, Kyiv, Ukraine \\ ORCID ID ${ }^{\mathbb{D}}: \underline{{ }^{1} 0000-0002-6135-7885}, \underline{20000-0003-1014-4393},{ }^{3} \underline{0000-0002-6773-9489}$
}

\begin{abstract}
It is known that forming of market economy depends on the behavioral actions of the enterprises, that work in the conditions of severe competition. Business processes and their consequences are based on the specific types of enterprises' behavior that can be envisaged with correction and forecasting. For this reason the question of studying the terms of enterprises' behavior forming as bases of decision of economic and organizational problems is important with the aim of choice and creation of effective model of enterprise's behavior taking into account the external and internal factors of influence. The results of the research show that this question was actively studied by scientists and caused varied discussions. The results of scientific searches of essence and typification of enterprises' behavior in modern terms are presented in the article. The necessity of application the different types of enterprise's behavior for achieving the enterprise's aims is established. The special attention must be tend to the consumer-oriented enterprise's behavior that has to take into account the wish of consumers of enterprise's products. The algorithm of the process of consumer-oriented enterprise's behavior forming is offered. It consists of two blocks: preparatorily analytical and correcting, sequence and logic actions implementation will allow to the enterprise to react on market changes in time and economic challenges for achieving certain progress trends. On the basis of the research behavioural principles of the development of enterprises the classification signs of enterprise's behavior are systematized and authorial criterion signs that extend this classification are offered, namely: level of consumers's informatization; environment of enterprise's activities; co-operating with end-user; type of consumers's generation; level of enterprise's digitalization.
\end{abstract}

\section{INTRODUCTION}

The development of enterprises in modern terms depends on the process of making decision by economic agents in the different spheres of economy. Rationality and strategic expediency of enterprise's behavioral strategies forming at the market depend on reasons, options, terms and expectations of economic agents. Scientists that develop the theoretical base of behavioural principles of enterprises' development conduct empiric researches within the framework of behavioural conception of enterprises' functioning, paying attention to the study of human's behavioural features in the process of economic relations within the framework of economic theory development.

Transformation of the economic systems, innovation in entrepreneurial activity, capacity of people for creative thinking, to the eccentric decisions and actions resulted in appearing relatively new direction of economic science development - behavioural economics. Scientists and experts try to learn influence of the psychological phenomena of a person, his/her emotions on the making of economic decisions. Behavioural approach is inherent to the activity of different subjects from an individual and enterprise to the market and regions. Zh. Koiev (2016) determines behavioural economics as «area of economic knowledge, that studies how social, cognitive and emotional factors influence on the making of economic decisions by people and organizations, and also as made decision influence on the market» (Pavlov et al., 2016). The Nobel laureate H. Simon (1955) is regarded as the founder of behavioural economic theory, whose scientific works had interdisciplinary character and united the information theory, psychology, mathematical and computer design of making decision (Thaler, 2017).

But we consider that selection of behavioural science in the separate area of knowledge would be impossible without other scientific works of scientists who under different visual angles investigated during many years the behavioural actions of people, consumers, financiers, competitors, 
partners, managers, firms owners, and also enterprises' behavior of different patterns of ownership on the market. Therefore, ponderable contribution to development of behavioural economy was done by many scientists the scientific achievements ofwhose gave an opportunity to distinguish basic directions of behavioural economy development: behavioural theory of personality; behavioural theory of consumption; behavior of consumer; behaviouraltheory of finance and theory of auctions; behavioural theory of enterprises of different patterns of ownership.

Enterprise's behavior can be examined as practical display of theoretical principles of history of economic studies. Therefore, we consider that it is necessary to distinguish the groups of theories, that explain the essence and describe the character of enterprises' activity in competition environment, determining the features of enterprises' behavior at the market in the conditions of dinamically-changeable environment and behavior of commodities customers and also to define the factors of influence on enterprise's behavior.

\section{METHODS}

The research is based on the use of general scientific methods, i.e. theoretical analysis is used to determine the impact of Consumer's behavior theory on the behavioural theory of the enterprise in different forms of property; factor analysis is used to determine the direction and strength of the impact of individual factors influencing the development of behavioural theory of the enterprise; analysis and synthesis is implemented to develop The algorithm of the process of forming consumeroriented behavior of the enterprise.

\section{Essence of category «behavior of the enterprise» with the consumer-oriented approach.} In economic theory the enterprise's conception is examined as a system of approaches that exposes the essence, behavior, evolution and other aspects of enterprises' functioning. In different times of scientific epochs the theory of enterprise was filled up by research and practice principles, various models of enterprise management, scientific approaches to understanding of behavioral consumers' actions and the process of making their decisions about purchases (Figure 1).

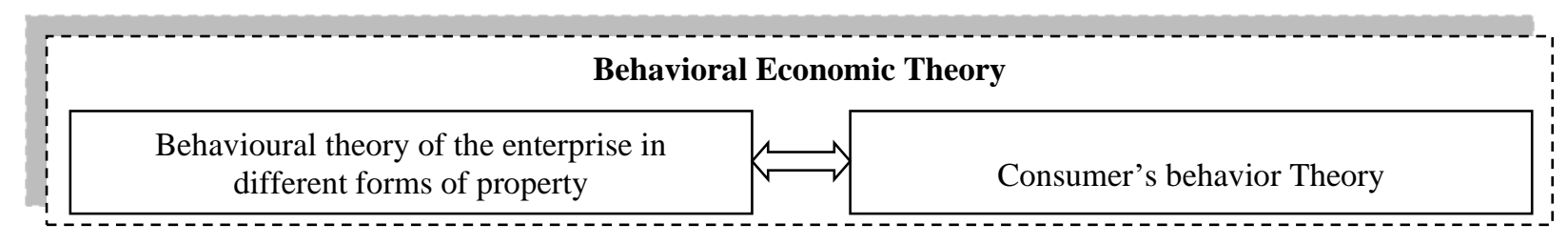

Fig. 1. Combination of behavioral economic theories

Source: prepared by the authors

Therefore, it is absolutely logically to study the evolution development of the enterprise, understanding the features of consumers' behavior, with that enterprises enter into the market relations, that will allow to support new progress of modern economic theory trends - to converge relatively separated directions of economic theory. Exposing the essence of economic behavior of the enterprise, H. Kaplenko (2005) takes a leading role to strategic activity and offers classification of different types of economic behavior on certain descriptions of its forming: morality, functions of economic culture, psychology, creative character, market orientation, rules of behavior, psychology of enterprise and its size, motivation of guidance and enterprise strategy, sociocultural and social psychological factors, types of enterprises by Nelson and Berson. V. Pastukhova (Pavlov et al., 2016) investigated the classification signs of types of enterprises' behavior by Nelson and Bernson, in detail describing passive expectation, busy wait, passing of changes, and stimulation of desirable changes.

N. Karachyna (2009) made a contribution to theoretical and methodological base of economic enterprises' behavior forming and added to the already well-known classification signs of types of enterprises' behavior (Karachyna, 2009) as the state and terms of development, distinguishing economic behavior of safety, economic behavior of survival, economic behavior of inert existence, economic behavior of increase. In addition, the conception of economic behavior model that is able 
to provide safety of the development of machine-building enterprise was offered by this author. Conception of economic behavior model that is able to provide the competitiveness of dairy milk processing enterprise at the market, is worked out by N. Hanzienko (Kaplenko, 2005).

A. Kudinova (2004) considered much attention to the theoretical comprehension of essence of the category by «enterprise's behavior» and to the research of components that contain its contents. Many researchers exposed and formed theoretical and methodological principles of enterprise mission in modern world. O. Malysh (2006) examines the problems of adequate market behavior forming in aggressive and changeable business-environment, taking into account strategic positions of the enterprise (Kapinus, 2021).

I. Ansoff (1979) pays attention to the organizational enterprise's behavior and grounds the types of organizational behavior (increasing and entrepreneurial). Studying management strategies, S. Solohub (2001) distinguishes the types of strategic enterprises' behavior depending on principles: principle of self-determination, principle of adaptation, principle of innovative perfection. Important researches of investment enterprises' behavior which were worked out by I. Skvortsova, O. Kryman, S. Dzheresad (Karachyna, 2009) and concentrated attention on the actions of investors that through the row of reasons made decision on planning and realization of strategic development of enterprises. Informative enterprises' behavior that envisages informatively-communication cooperation between the participants of market, envisages the following types: adaptive, structural, destructive, initiative and reactive (Kapinus, 2021).

With the aim of repetition avoidance and providing of successful enterprises functioning in market conditions, deem it advisable to pay more attention to marketing theory and add classification signs priority of enterprise's orientation on marketing aims, distinguishing the types of enterprises' behavior: productive-oriented, sale-oriented and consumer-oriented. The productive-oriented enterprise's behavior is directed in support of functioning and providing development of productive potential. The accent of entrepreneurial activity is put on the production of goods with orientation on the indexes of production efficiency. Enterprise's sale behavior is sent to the production of goods with preset parameter of quality and aggressive sale through the various channels of distribution. Much attention is payed to the target market and analysis of results that correct the enterprise's behaviour operating on the market. The consumer-oriented enterprise's behavior is sent to the increase of satisfaction the necessities and improvement of consumers relation to the products of thr enterprise. Research of consumers' behavior and potential possibilities of target market is important stage in forming of enterprise' behavior model. It is educed during the research, that the concept «enterprise's behavior» in the process of evolution was transformed and can be examined separately of every enterprise for explanation and prognostication of causal mechanism of the real events in economy. History of forming approaches, theories, conceptions of enterprise's behavior presents the evolution within the framework of the general economic theory formation. On the basis of established material above and on the basis of own researches the authorial approach to the interpretation of concept «enterprise's behavior» is offered. Enterprise's behavior is economic category that envisages totality of actions, methods and solutions of enterprise's reactions on influential factors from the side of internal and external environment, taking into account dominant variations of economic behavior (strategic, innovative, entrepreneurial, organizational, informative, competitive, market, social responsible) with the aim of achieving aims of the enterprise that has the consumer-oriented approach to the eventual administrative decisions acceptance.

The detailed typification of enterprises' behavior takes into account the market conditions, environment, enterprise, changes in economy that allow to form the enterprise's behaviour model with the aim of effective decisions acceptance and forming of algorithm of this model actions realization for achieving the certain progress of the enterprise trends is given (Figure 2). 


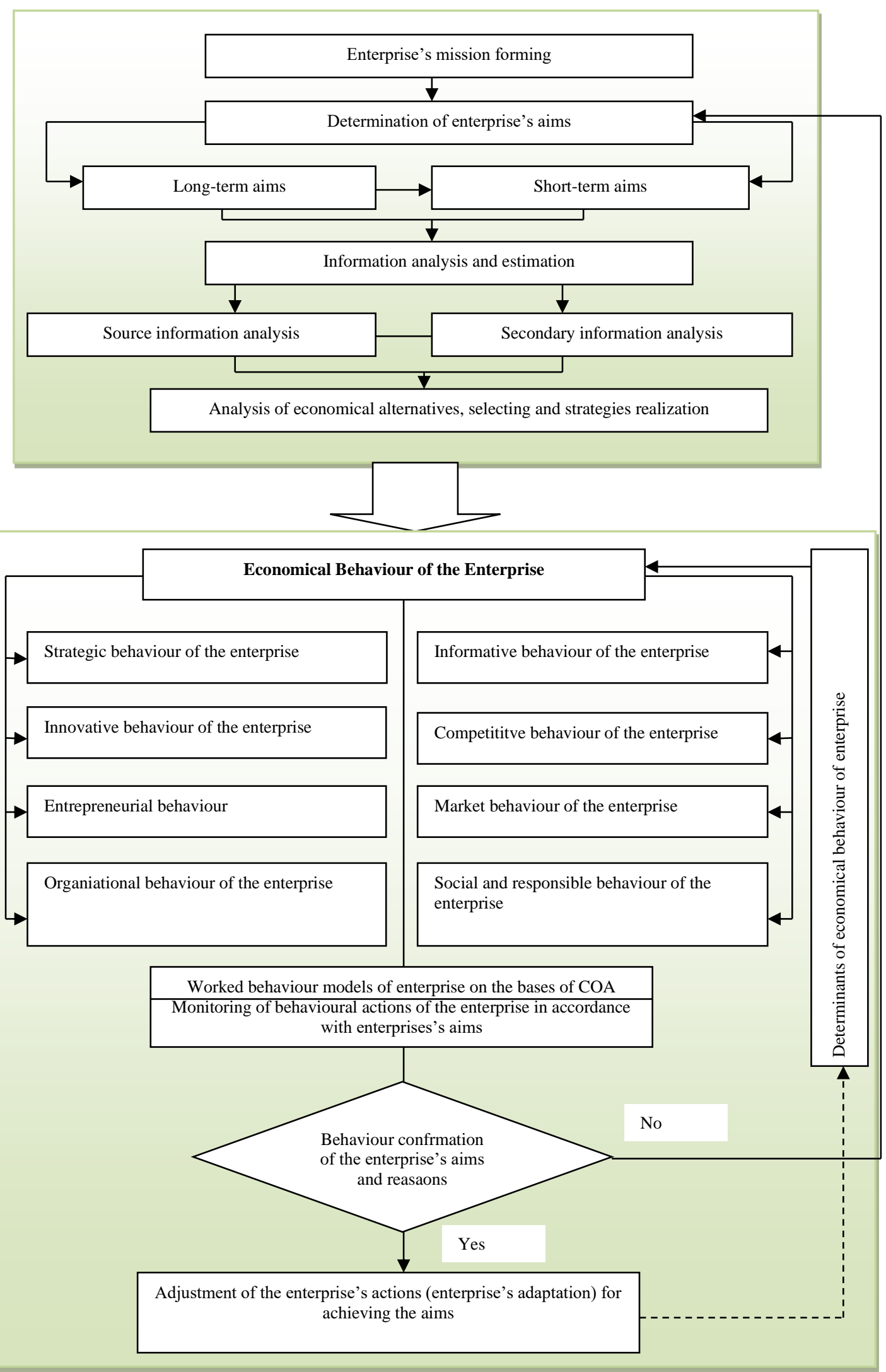

Fig. 2. The algorithm of the process of forming consumer-oriented behavior of the enterprise Source: prepared by the authors 
The algorithm of forming of economic enterprise's behavior process has cyclic character and consists of two blocks. The first block is «Preparatorily-analytical» includes determination of enterprise mission, establishment of enterprise aims, analysis and evaluation of information and analysis of economic alternatives, their choice and realization. Mission of the enterprise is set by top management and promulgated general strategic aim of the enterprise, contents of its existence from the point of view of public interests. It is original compromise between the consumers necessities and possibilities and enterprise desires. Some scientists, for example V. Barancheiev (2007), examine missions by separate constituents. Mission-setting is clear understanding of enterprise's origin of reason and maintenance of their existence. Mission-orientation determines the enterprise's guidance attitude toward the different interested groups of influence on the basis of unfolded idea about the system of values that the enterprise adheres to.

Between the aims must be clear hierarchy, where every structural subdivision set objectives consonant with the aims of other subdivisions, so that they were organically written into determination of primary objective of enterprise activity. Primary objective is achieved during the realization of aims of lower level (short-term aims). Difficult objectives of organizations structurises at the use of such instrument, as «tree of aims», where higher level is interpreted as primary objective of the enterprise functioning that is changed into hierarchical structure. The amount of levels depends on organisational structure of the enterprise, and aims complication. Basis of «tree of aims» where the types of work are set, facilities and terms of implementation are determined. Every event must answer the aims of higher level and be materially supported. For every event there must be certain charges and expected effect (Samuliak, 2008).

The next stage is analysis and evaluation of information, that are based on the data got from the primary and secondary sources of the enterprise. Primary information is the informative materials got in the result of specially undertaken sociological studies for the decision of certain problem. Their collection comes true by supervisions, questioning, experimental researches. For realization of primary marketing information collection, the enterprise must have corresponding resources, such as: specialists who own qualification in area of collection, processing and analysis of information; methodical providing of work with information, as the methods of collection and processing of information influence on its quality; necessary equipment that allows to register information during the research. Secondary information is information that gathers from different sources for other aims. Secondary data help the enterprise better acquainted with the situation in industry, with the tendencies of sales volumes change and profit, competitors activity, innovative technologies and developments in area of science. The accumulated information forms permanent infobase. Episodic information gathers irregularly, used in the special situations, when guidance is unable to define the enterprise's behavioural operating on the market.

On the basis of informative knowledge the enterprise carries out the analysis of economic alternatives, elects those directions of activity that answer potential of the enterprise. We consider that one of directions of economic feasibilities realization is forming of economic behavior of the enterprise at the market.

The second block, «Correcting» is devoted to economic enterprise's behavior that must take into account its aims and mission.

The selection types of economic enterprise's behavior gives an opportunity to concentrate effort of the enterprise on those directions of economic activity that represent character and essence of economic activity on the basis of interinfluence of corresponding determinants. We consider that any type of economic behavior that is represented in the algorithm, must be oriented on the consumer. Therefore, the development of enterprise's behavioral models must be based on the consumeroriented approach. With the aim of exposure of use the behavioural models efficiency it cis needed to conduct monitoring of enterprise's behavioural actions according to the enterprise's aims. If enterprise's behavior answers the aims and reasons of the enterprise (table 1), then it is needed to continue such behavior, if necessary correcting the enterprise actions for achieving the aims. Thus, it is necessary to take into account determinants of economic enterprise's behavior. 
Table 1. Reasons of the enterprise

\begin{tabular}{|ll|}
\hline Reasons of profitability & $\begin{array}{l}\text { Desire of the enterprise to get a profit in competitive activity, providing new } \\
\text { products producing with high added value. From one side, a profit comes } \\
\text { forward as financial source, and on the other hand, a profit is the aim of } \\
\text { investing. }\end{array}$ \\
\hline Reasons of stability & $\begin{array}{l}\text { Aspiration of the enterprise to stability of productive process, increase of } \\
\text { goods volumes production with high added value, maintenance and increase } \\
\text { of market share. }\end{array}$ \\
\hline Reasons of surviving & $\begin{array}{l}\text { Desire of the enterprise to provide the survival in the conditions of } \\
\text { eurointegration and transition of business on on-line-market. }\end{array}$ \\
\hline $\begin{array}{l}\text { Reasons of competitiveness } \\
\text { increase }\end{array}$ & $\begin{array}{l}\text { Desire to produce quality and competitive products, occupy the leading } \\
\text { position at the market. }\end{array}$ \\
\hline $\begin{array}{l}\text { Reasons of strengthening relations } \\
\text { with consumers }\end{array}$ & $\begin{array}{l}\text { Desire of the enterprise to increase the amount of consumers, promote their } \\
\text { loyalty, work on individualization of consumers' queries. }\end{array}$ \\
\hline
\end{tabular}

Source: (Korytko, 2018) with author's addition

If enterprise's behavior does not answer the aims and reasons of the enterprise, it is needed to revise behavioural models and enterprises' objectives, in fact often the enterprise reaction on external environment changes can change the enterprises' objectives.

Factors of influence on the consumer-oriented enterprises' behavior forming. In the conditions of permanent change of enterprise's environment it is important to find the ways of optimization market activity of the enterprises for achieving success. Certainly, to own deep knowledge about each factors that has the influence on the activity of certain enterprise, it is impossible, in fact generous amount from them cannot have tendencies to development and be unforeseeable. However, every enterprise must create the row of behavioural strategies, actions and adaptation of enterprises' behavior in accordance with the most real and critical factors of influence. Nowadays and until now the greater amount of enterprises doubtfully behaves to the crisis management and critical analytics of future periods that is why does not develop the similar plans of actions for business maintenance. Therefore, the selection of influence factors on enterprises' behavior and development of modern classification will allow to develop the theoretical base of behavioural principles of enterprises development in modern economy and to serve as the secondary information source for the operative decisions acceptance and opening additional possibilities with the aim of of negative consequences warning for business.

For today any enterprise is the system that constantly co-operates with the elements of environment. Exactly these elements-factors influence on their behavior and come forward as main circumstances for forming of development strategy. In the general understanding of environment of enterprise concept, it is taken from the sphere of management, where the external and internal factors of influence are distinguished in relation to certain subject of activity. However, in modern environment there is plenty of factors, that goes far beyond the frameworks of classic classification of XX century. Certainly, each of factors influences on common enterprise's behavior and partly line up its vector of aspiration, their degree of influence and source is differ. For this reason, there is a necessity for the unfolded classification of influence factors on enterprise's behavior in accordance with the modern market activity conditions of the subjects of management. Systematization of influence factors by basic classification signs is given in the Table 2 . 
Table 2. Classification of influence factors on enterprise's behavior

\begin{tabular}{|c|c|c|c|c|c|}
\hline Classification sign & \multicolumn{5}{|c|}{ Types of factors } \\
\hline 1 & \multicolumn{5}{|c|}{2} \\
\hline & \multicolumn{2}{|c|}{ Internal environment } & \multicolumn{2}{|c|}{ Microenvironment } & Macroenvironment \\
\hline Sphere of origin & \multicolumn{2}{|c|}{$\begin{array}{l}\text { - legal organisational form } \\
\text { - enterprise mission and } \\
\text { objectives } \\
\text { - qualification personnel level } \\
\text { - organisational culture } \\
\text { - product competitiveness }\end{array}$} & \multicolumn{2}{|c|}{$\begin{array}{l}\text { - raw material suppliers } \\
\text { - negotiants } \\
\text { - consumers } \\
\text { - competitors } \\
\text { - responsive group of } \\
\text { consumers }\end{array}$} & $\begin{array}{l}\text { - political climate } \\
\text { - economical state } \\
\text { - demographic factors } \\
\text { - sociaocultural factors } \\
\text { - level of scientific and } \\
\text { technical development } \\
\text { - ecological situation }\end{array}$ \\
\hline \multirow[b]{2}{*}{ Sphere of influence } & \multicolumn{2}{|c|}{ All-management } & \multicolumn{2}{|c|}{ Marketing } & Specific \\
\hline & \multicolumn{2}{|c|}{$\begin{array}{l}\text { - government control } \\
\text { - activity strategy } \\
\text { - product and price policy } \\
\text { - economical environment }\end{array}$} & \multicolumn{2}{|c|}{$\begin{array}{l}\text { - competitive environment } \\
\text { - тенденції маркетингу } \\
\text { - еволюція споживача } \\
\text { - advertising activity } \\
\text { - demand of products and } \\
\text { their positions }\end{array}$} & $\begin{array}{l}\text { - production technologies } \\
\text { - state of equipment } \\
\text { - raw materials } \\
\text { - innovations } \\
\text { - qualification of working } \\
\text { personnel }\end{array}$ \\
\hline \multirow[b]{2}{*}{$\begin{array}{l}\text { Level of influence } \\
\text { on the activity }\end{array}$} & \multicolumn{2}{|c|}{ Strong influence } & \multicolumn{2}{|c|}{ Middle influence } & Low influence \\
\hline & \multicolumn{2}{|c|}{$\begin{array}{l}\text { - economical state } \\
\text { - legal base } \\
\text { - military situation in the } \\
\text { country and the world } \\
\text { - level of industry control }\end{array}$} & \multicolumn{2}{|c|}{$\begin{array}{l}\text { - market capacity } \\
\text { - launching of ew product } \\
\text { - technological level of } \\
\text { industry } \\
\text { - level of competition }\end{array}$} & $\begin{array}{l}\text { - customer development } \\
\text { - market tems } \\
\text { - state of distribution outlets } \\
\text { - advertising and } \\
\text { communication activity }\end{array}$ \\
\hline \multirow[b]{2}{*}{ Infuence duration y } & \multicolumn{3}{|c|}{ Long-term actions } & \multicolumn{2}{|c|}{ Short-term actions } \\
\hline & \multicolumn{3}{|c|}{$\begin{array}{l}\text { - economic population stability } \\
\text { - ecological state in the region } \\
\text { - legislative and normative base functioning }\end{array}$} & \multicolumn{2}{|c|}{$\begin{array}{l}\text { - advertising activity } \\
\text { - modern tendencies in industry - new products } \\
\text { - scientific and technical progress }\end{array}$} \\
\hline \multirow[b]{2}{*}{ Type of production } & \multicolumn{3}{|c|}{ Product } & \multicolumn{2}{|r|}{ Service } \\
\hline & \multicolumn{3}{|c|}{$\begin{array}{l}\text { - raw materials } \\
\text { - distribution chain } \\
\text {-technical and technological } \\
\text { - competitiveness }\end{array}$} & \multicolumn{2}{|c|}{$\begin{array}{l}\text { - consumer geography } \\
\text { - consumer psychology } \\
\text { - social and cultural environment } \\
\text { - classification of working personnel }\end{array}$} \\
\hline \multirow[b]{2}{*}{$\begin{array}{c}\text { Sphere of } \\
\text { enterprise activity }\end{array}$} & \multicolumn{2}{|l|}{ B2B-market } & \multicolumn{2}{|c|}{ B2C-market } & B2G-market \\
\hline & \multicolumn{2}{|l|}{$\begin{array}{l}\text { - client geography } \\
\text { - production capacity } \\
\text { - natural and climatic } \\
\text { conditions }\end{array}$} & \multicolumn{2}{|c|}{$\begin{array}{l}\text { - distribution chains } \\
\text { - advertising } \\
\text { - evolutionary of consumer } \\
\text { - market capacity }\end{array}$} & $\begin{array}{l}\text { - big production capacity } \\
\text { - government control }\end{array}$ \\
\hline \multirow[b]{2}{*}{ Evolutionary } & \multicolumn{3}{|c|}{ Permanent } & \multicolumn{2}{|r|}{ Temporary } \\
\hline & \multicolumn{3}{|l|}{$\begin{array}{l}\text { - political climate } \\
\text { - ecological situation } \\
\text { - economical situation } \\
\text { - globalisation } \\
\end{array}$} & \multicolumn{2}{|c|}{$\begin{array}{l}\text { - scientific and technical progress - modern } \\
\text { tendencies } \\
\text { - digital trade transformation }\end{array}$} \\
\hline & Disrupters & & adopters & Majority & Conservatives \\
\hline Consumer types & $\begin{array}{l}\text { - modern tendencies } \\
\text { - innovations } \\
\text { - scientific and } \\
\text { technical progress }\end{array}$ & $\begin{array}{l}- \text { nov } \\
- \text { mar }\end{array}$ & ting efforts & $\begin{array}{l}\text { - personal income } \\
\text { - product } \\
\text { availability }\end{array}$ & $\begin{array}{l}\text { - demand on products } \\
\text { - social value of products } \\
\text { - product image }\end{array}$ \\
\hline & Obj & tive & & & Subjective \\
\hline Nature of factor & $\begin{array}{l}\text { - social } \\
\text { - political } \\
\text { - economical } \\
\text { - demographic }\end{array}$ & & & $\begin{array}{l}\text { - nature-climatic } \\
\text { - ecological } \\
\text { - mental }\end{array}$ & \\
\hline & Increasing & & & Maturity & Decline \\
\hline
\end{tabular}




\begin{tabular}{|c|c|c|c|c|c|}
\hline $\begin{array}{l}\text { Life cycle stage of } \\
\text { the enterprise }\end{array}$ & \multicolumn{2}{|c|}{$\begin{array}{l}\text { - barriers of market entrance } \\
\text { - product novelty } \\
\text { - supply and demand at the } \\
\text { market } \\
\text { - financial reserves } \\
\text { - tax policy }\end{array}$} & \multicolumn{2}{|c|}{$\begin{array}{l}\text { - legal stability } \\
\text { - business reputation } \\
\text { - management level } \\
\text { - personnel motivation }\end{array}$} & $\begin{array}{l}\text { - competition in industry } \\
\text { - marketing policy } \\
\text { - distribution chain } \\
\text { - production constituent } \\
\text { - leaving market barriers }\end{array}$ \\
\hline & \multicolumn{3}{|c|}{ Internal } & \multicolumn{2}{|r|}{ External } \\
\hline Force majeures & \multicolumn{3}{|c|}{$\begin{array}{l}\text { - production accident } \\
\text { - death or sickness of key persons } \\
\text { - resourceshortagesin industry }\end{array}$} & \multicolumn{2}{|c|}{$\begin{array}{l}\text { - epidemic } \\
\text { - cnatural hazards } \\
\text { - military actions } \\
\text { - ecological catastrophes } \\
\end{array}$} \\
\hline \multirow[b]{2}{*}{$\begin{array}{c}\text { Type of } \\
\text { competition }\end{array}$} & \multicolumn{2}{|c|}{ Monopolistic competition } & \multicolumn{2}{|r|}{ Monopoly } & Oligopoly \\
\hline & \multicolumn{2}{|c|}{$\begin{array}{l}\text { - level of competition } \\
\text { - advertising activity } \\
\text { - consumer opening } \\
\text { - barriers of entrance and leaving }\end{array}$} & \multicolumn{2}{|c|}{$\begin{array}{l}\text { - state regulation } \\
\text { - legal abuse } \\
\text { - consumer abundance } \\
\text { - resource availability }\end{array}$} & $\begin{array}{l}\text { - level of competition } \\
\text { - degree of innovations } \\
\text { - resource availability } \\
\text { - market capacity }\end{array}$ \\
\hline \multirow[b]{2}{*}{$\begin{array}{l}\text { Level of consumer } \\
\text { informatisation }\end{array}$} & \multicolumn{2}{|c|}{ Low } & \multicolumn{2}{|r|}{ Middle } & High \\
\hline & \multicolumn{2}{|c|}{$\begin{array}{l}\text { - printed periodical editions } \\
\text { - word-of-mouth } \\
\text { - reference group }\end{array}$} & \multicolumn{2}{|c|}{$\begin{array}{l}\text { - free access to the Internet } \\
\text { - external advertising } \\
\text { - inside leaders }\end{array}$} & $\begin{array}{l}\text { - mobile applications } \\
\text { - digital trade } \\
\text { - free service usage }\end{array}$ \\
\hline & \multicolumn{2}{|c|}{ Online environment } & \multicolumn{2}{|c|}{ Internet-environment } & Off-line environment \\
\hline $\begin{array}{c}\text { Environment of } \\
\text { enterprise activities }\end{array}$ & \multicolumn{2}{|c|}{$\begin{array}{l}\text { - social networks } \\
\text { - messengers } \\
\text { - mobile applications and games } \\
\text {-informational online-resources }\end{array}$} & \multicolumn{2}{|c|}{$\begin{array}{l}\text { - search systems } \\
\text { - mass media sites } \\
\text { - context and search } \\
\text { advertising } \\
\text { - Internet-portals }\end{array}$} & $\begin{array}{l}\text { - printed leaflets } \\
\text { - external advertising } \\
\text { - advertising in transport } \\
\text { - TV } \\
\text { - advertising in sales places }\end{array}$ \\
\hline \multirow[b]{2}{*}{$\begin{array}{l}\text { Compatibility with } \\
\text { end user }\end{array}$} & \multicolumn{3}{|c|}{ Online-consumers } & \multicolumn{2}{|c|}{ Off line-consumers } \\
\hline & \multicolumn{3}{|c|}{$\begin{array}{l}\text { - product-placement } \\
\text { - Internet } \\
\text { - online-advertisement } \\
\text { - influencer's comments } \\
\text { - virus content }\end{array}$} & \multicolumn{2}{|c|}{$\begin{array}{l}\text {-TV } \\
\text { - external advertising } \\
\text { - promoters } \\
\text { - personal contact with consumer } \\
\text { - word of mouth }\end{array}$} \\
\hline \multirow[b]{2}{*}{$\begin{array}{l}\text { Type of } \\
\text { consumers } \\
\text { generation }\end{array}$} & Generation X & \multicolumn{2}{|c|}{ Generation $\mathrm{Y}$} & Generation Z & Generation A \\
\hline & $\begin{array}{l}\text { - balance } \\
\text { - stability to } \\
\text { tendencies }\end{array}$ & \multicolumn{2}{|c|}{$\begin{array}{l}\text { - technologies } \\
\text { - health } \\
\text { - climate and ecology }\end{array}$} & $\begin{array}{l}\text { - self-realisation } \\
\text { - personal freedom } \\
\text { - activeness } 24 / 7 \\
\end{array}$ & $\begin{array}{l}\text { - nonseparable world } \\
\text {-moral standards } \\
\text { - personalization }\end{array}$ \\
\hline \multirow[b]{2}{*}{$\begin{array}{l}\text { The level of } \\
\text { enterprise's } \\
\text { digitalization }\end{array}$} & \multicolumn{2}{|c|}{ Low } & & Middle & High \\
\hline & \multicolumn{2}{|c|}{$\begin{array}{l}\text { - print digital transition } \\
\text { - resource saving }\end{array}$} & \multicolumn{2}{|c|}{$\begin{array}{l}\text { - computer application of } \\
\text { records } \\
\text { - new type intermediary }\end{array}$} & $\begin{array}{l}\text { - digital business transition - } \\
\text { flow of digital revenues } \\
\text { - image optimization }\end{array}$ \\
\hline
\end{tabular}

Source: prepared by the authors

In this classification the influence factors on enterprise's behavior are given 17 basic signs that influence on activity of any subject of management at the market. All these factors also can be divided into guided by the enterprise and those uncontrol factors on which the enterprise tries to influence. In accordance with the researches of influence factors, swinging majority of scientists and researchers specify on more substantial influence of those factors that are out of control. In different literary sources such classification signs of influence factors on enterprise's behavior are investigated: sphere of origin (internal environment of enterprise, macro- and microenvironment), sphere of influence (all-management, specific, to marketing), degree of influence on activity (strong, middle, low), duration of influence (short-term actions and long term actions), type produced products, sphere of activity, evolutional, type of special purpose consumer, nature of factor, stage of life cycle of the enterprise, force-majeures, type of competition.

We consider that in the modern world the enterprises' behavior forming influence on the level of consumers informatization, environment of enterprise activities, co-operating with end-user, type of consumers generation and level of enterprise's digitalization. 
The level of consumers informatization comes forward as an important classification sign of influence factors. Today consumers try to get not only the product for satisfaction their necessity, but something anymore - reliability and safety from a brand that can they trust. Thus, the degrees of informatization can be conditionally divided into three groups: low, middle and high. At the low level of informatization consumers search information in print periodic editions, collect reviews from the acquaintances about the commodity or producers and try to attribute himself / herself to the certain reviewer group. All these facilities testify about the low level of awareness in modern informative instruments that is characteristic forelder people and low economic providing. To the middle level of informatization it is possible to take the following factorsfactors: free access to the Internet, external advertisement and transport and certainly, reviews of inside leaders. This degree is characteristic for the generation of middle age, that have basic skills in using modern informative instruments. A high level is accompanied by the active use of mobile applications, by activity of population in digital trade (purchases over the Internet), representatives use online-services freely and searching systems. This degree of informatization is characteristic for young pople, that freely use the online-systems and give advantage to the economy of time, buying commodities on-line.

Environments of entrepreneurial activity are further qualifying sign, as the environment imposes the corresponding models of subjects' behavior. Here, it is possible to distinguish three groups of environments: on-line-environment, Internet-environment and off-lineen vironment. The factors of online-environment influence involve: social networks (with condition of doing business and trade changed radically) that became a great platform for digital trade, by basic environment for advertisement activity of brands and fascination of audience; messengers new high-perspective channel for advertisement and increase of information about the product (telegram, viber), where it is possible to start intereactive bot chats; mobile applicationsand games, in accordance with statistics everybody conducts about 2 th hours a day in mobile applications; informative online-resources are Internet-versions of rating editions, online-magazines and others like that (Statista.com, 2020).

To the internet-environment it is possible to take the searching systems (Google, Yahoo, Bing, Rambler, Forex, Baidu and others like that) where maybe on-request got any information, and thus to mark out the advertisement on interests and queries. The web-sites of Mass Media have the most visited Internet-users among informative resources in Internet, and their reviews influence on perception of information users.

Certainly, printed editions, external advertisement, advertisement in transport, cable television and word-of-mouth advertisement are the factors of the influence of enterprise's off-line environment. All these instruments belong to the sphere of classic marketing and lose their efficiency, but until now have large influence on the audience of conservatives and elder people (Moklaik et al., 2015). The sphere of co-operating with consumer for today becomes one of the basic groups of factors that influence on enterprise's behaviour also. There are two main types of consumers: online- and off-line consumers. To understand the difference between these two types of consumers, it is necessary to consider comparative description, as for representatives of each of these types the behavior extraordinarily differs. Description is given in the Table 3. For the economy of time important factors for online-consumers are products presentation by the enterprise on the platforms of product-placement, as it is important now for consumers to read about the product (other customers description and reviews) and compare them with the reliable analogues, tested salespeople (Rozetka, Prom.ua and others like that). In online-environment this process is fast and more comfortable, than off-line, as the process of market research and comparison of variants occupies minimum of time, in fact all necessary information is in one place. Carrying out the purchase is possible in any place and time. The amount of online-consumers grows for this reason, in fact the question of comfort and economy of resources becomes more actual, and the issue of safety is important for majority of producers, and they create the direct sales channels. 
Table 3. Comparative characteristicsof online- and off-line-consumer

\begin{tabular}{|c|c|c|}
\hline $\begin{array}{l}\text { Characteristic } \\
\text { feature }\end{array}$ & Online-consumer & Off-line consumer \\
\hline Needs & $\begin{array}{l}\text { To purchase a good commodity in } \\
\text { comfortable place for consumer and in the } \\
\text { most comfortable for consumption time. }\end{array}$ & $\begin{array}{l}\text { To purchase a quality and safe commodity, } \\
\text { personally making sure in its properties. }\end{array}$ \\
\hline Reasons & $\begin{array}{l}\text { Reason of online-consumers is economy. It is } \\
\text { led that online-shops sell off products cheaper } \\
\text { than ordinary, providing services of door } \\
\text { delivery in comfortable for a consumer time. } \\
\text { A consumer spends time only on registration } \\
\text { of consumer basket and payments. }\end{array}$ & $\begin{array}{l}\text { This type of consumers in majority is } \\
\text { conservatives, that does not trust } \\
\text { surrounding in many questions especially } \\
\text { financial. They are ready to spend much } \\
\text { money and spend to time on searching } \\
\text { information about thecommodity off-line, } \\
\text { try personally choose the product and make } \\
\text { sure that the commodity meets their } \\
\text { expectations. }\end{array}$ \\
\hline Values & $\begin{array}{l}\text { The main value of this type of consumer are } \\
\text { time and personal comfort. For on-line- } \\
\text { consumer it is the most important resources. } \\
\text { He/ she aims to spend a minimum of time on } \\
\text { searching and process of purchasing in a } \\
\text { comfortable place. }\end{array}$ & $\begin{array}{l}\text { The value for off-line consumer consists in } \\
\text { safety and quality of product. For } \\
\text { achieving these values this type of } \\
\text { consumer must check up everything } \\
\text { personally. He/she does not repent time } \\
\text { expended in the process of searching and } \\
\text { purchasing, as he/ she does not trust online- } \\
\text { trade. }\end{array}$ \\
\hline
\end{tabular}

Source: prepared by the authors

Almost all online-purchases are through the Internet, for this reason it is the fundamental factor for e- commerce-projects. On-line-advertisement for today is the most effective marketing instrument for the achievement of identification and increase of conversion. Reviews from influencers acquire importance for the target audience of brands, as they come forward as the expert estimation and can change positions of the enterprise both in the best and in worst side. The king of any advertisement is content, in 2021 it is important to create quality and trend content that has chances to become viral, in fact only such content sells itself and memorized by the audience - the prime example of Ukrainian creation of such content is Bart\&Fink. Off-line consumers in the majority are «late majority» and «conservatives» that is inclined to the considerable level of mistrust to modern technologies. Off-line environment of the enterprises contact with consumers through television (advertisement and sponsorship), carriers of external advertisement, work of promoters on streets and places of sale, personal contact with consumer and word-of-mounth advertising. From quality work each of these elements depends activity success of subject management and in environment on the whole.

The type of consumers' generation is not simply important factor of influence on enterprise's but one of basic fundamental ones. Each of these types provided with different necessities (except physiological base), reasons and values that form the type of consumer (his/ her necessities) and requirements to the producers of products. Description is given in the Table 4. The level of enterprises' digitalisation is the last from the given qualifying signs of influence factors on enterprises's behavior. This type is quite newand created evolutional by society, as the result of scientific and technical complex development. Digitalisation is called to optimize business processes, promoting the enterprise's productivity and to improve co-operating experience with consumers (Ustenko et al., 2019). It is possible to make three groups: influence factors of low, middle and high level of enterprise's digitalisation.

The low level of digital transformation of the enterprises is accompanied by translation of business information in digital form that not always passes successfully from the first time and influences on the further process of integration. 
Table 4. Description of types of consumers' generations

\begin{tabular}{|c|c|c|c|c|}
\hline Characteristic & Generation X & Generation $\mathbf{y}$ & GenerationZ & Generation A \\
\hline Needs & $\begin{array}{l}\text { Requirement in } \\
\text { comfort and feeling } \\
\text { of own unicity }\end{array}$ & $\begin{array}{l}\text { To achieve success } \\
\text { with the maximally } \\
\text { short period of time }\end{array}$ & $\begin{array}{l}\text { To expose the } \\
\text { potential and find } \\
\text { himself/ herself }\end{array}$ & $\begin{array}{l}\text { Want individualization } \\
\text { and personalisation of } \\
\text { everything. }\end{array}$ \\
\hline Reasons & 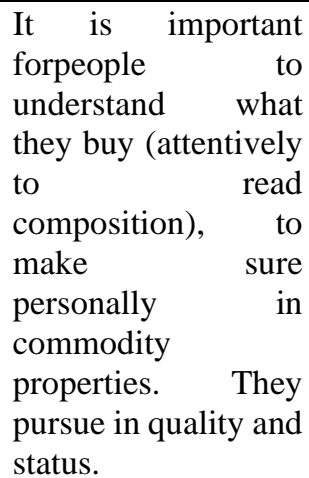 & $\begin{array}{l}\text { Each of } \\
\text { representatives of this } \\
\text { generation is } \\
\text { convinced, that he/ } \\
\text { she is special. } \\
\text { Extreme combination } \\
\text { of high self-appraisal } \\
\text { and unreal } \\
\text { expectations from } \\
\text { life, that do them } \\
\text { vulnerable. }\end{array}$ & $\begin{array}{l}\text { For "Z" generation it } \\
\text { is important to defend } \\
\text { possibility to be } \\
\text { different to the last. } \\
\text { The representatives } \\
\text { of this generation } \\
\text { suffer of self- } \\
\text { affirmation }\end{array}$ & $\begin{array}{l}\text { They are born in the } \\
\text { world, where all is tuned } \\
\text { under them. For this } \\
\text { reason they expect an } \\
\text { instantaneous } \\
\text { achievement desirable. It } \\
\text { is the most materially } \\
\text { provided generation. }\end{array}$ \\
\hline Values & $\begin{array}{l}\text { Family values, } \\
\text { freedom of choice, } \\
\text { safety and quality, } \\
\text { mprosperity and } \\
\text { health. }\end{array}$ & $\begin{array}{l}\text { Time, comfort, career } \\
\text { advancement, self- } \\
\text { realization, personal } \\
\text { freedom. }\end{array}$ & $\begin{array}{l}\text { Money, freedom of } \\
\text { actions and } \\
\text { communication, } \\
\text { technologies, } \\
\text { popularity, friends } \\
\text { and family, } \\
\text { ecofriendlyness. }\end{array}$ & $\begin{array}{l}\text { Personalisation, } \\
\text { individual approach, } \\
\text { innovations, family } \\
\text { relations, high moral } \\
\text { standards, empathy, } \\
\text { time. }\end{array}$ \\
\hline
\end{tabular}

Source: prepared by the authors

Accordingly on this stage the enterprises begin to save on certain resources that go out from turnover and invest savings in the processes of transformation.

The middle level is characterized by the factors of documentary work computerization and production that influences on time of working personnel adaptation and optimization of goods production. On this stage possibilities are opened for new type of mediation that influences on prestige of business reputation of the enterprise.

The high level of enterprise's digitalisation is testified to the complete transforming to digital business, mastering of trade digital platforms. At this level the enterprise gets considerable acuestss from digital sources (on-line-trade). Accordingly, the image of progressive enterprise is formed.

\section{CONCLUSIONS}

On the basis of the genesis of opening the theories of behaviour economy the progress of trends of enterprises's behavioral conception functioning is determined. Pre-conditions of behavioural theories origin are found out, accenting attention on the study of enterprises' behavior features and human behavior in the process of economic relations are established. It is proved that further development of enterprises' behavior theory in modern terms takes place within the framework of the development of behavioural process taking into account the determinants of enterprise's behavior, distinguishing behavioural consumers actions on the market as key referencepoints of enterprise activity.

Refering to the basic behaviour theory, it is determined that enterprise's behavior includes the different types of enterprise's behavior depending on setting goals. The necessity of application the different types of enterprise's behavior is reasonable for achieving the enterprise's aims. The special attention is devoted to the consumer-oriented enterprise's behavior that must take into account the consumers' wishes of products.

The algorithm of forming process of the consumer-oriented enterprise's behavior that consists of two blocks: preparatorily-analytical and correcting, sequence and logic of actions implementation that will allow to the enterprise to react in time on the market changes and economic challenges for achieving the certain progress trends is offered. 
The modern terms of market competition it is extraordinarily difficult «blindly» to conduct business-activity for the enterprises, and in this relation expediently monitoring and reacting on plenty of factors with the aim of forming enterprise's behavior at the market. We consider that it is expedient to use the consumer-oriented approach during the enterprise reacting on the challengers of external and internal environment.

With the aim of studying the determinants of enterprise's behavior the classification signs of factors that influence on economic enterprise's behavior are systematized, and authorial criterion signs that extend this classification is offered, namely: level of consumers informatization; environment of enterprise activities; co-operating with end-user; type of consumers generation; level of enterprise digitalisation. Taking into account the factors which were offered by the author will allow to the enterprise to direct their own behavioural potential at adaptation under new economic requirements with the aim of maintenance (achievement) market positions.

\section{REFERENCES}

Alalwan, A.A., Dwivedi, Y.K. \& Rana N.P. (2017). Factors influencing adoption of mobile banking by Jordanian bank customers: Extending UTAUT2 with trust. International Journal of Information Management, 37(3), 99-110. https://doi.org/10.1016/j.ijinfomgt.2017.01.002

Ansoff, H. Igor. (1979). Strategic Management. London, Palgrave Macmillan. https://doi.org/10.1007/978-1-349-02971-6.

Arnold, C., Kiel, D. and Voigt, K.-I. (2016). How the Industrial Internet of Things changes business models in different manufacturing industries. International Journal of Innovation Management, 20 (8), 1640015-1-1640015-25.

Drive business growth with a winning digital marketing strategy. https://bit.ly/2VZLo73

Golysheva, Ye., Kyrychenko, N., Kovalenko, Ya. (2014). Osoblyvosti vykorystannia instrumentiv internet-marketyngu na pidpryiemstvi [Features of using of internet-marketing instruments depending on the enterprise]. Molodyj vchenyj, 10 (13), 53-56.

Halley, A. and Guilhon, A. (1997). Logistics behaviour of small enterprises: performance, strategy and definition. International Journal of Physical Distribution \& Logistics Management, 27 (8), 475-495. https://doi.org/10.1108/09600039710182644

Herbert, A. Simon (1955). A Behavioral Model of Rational Choice. The Quarterly Journal of Economics, 69, (1), 99-118. https://doi.org/10.2307/1884852

Kahneman, D., Tversky, A. (1979). Prospect Theory: An Analysis of Decision under Risk. Econometrica, 47 (2), 263-291.

Kahneman, D., Tversky, A. (1974). Judgment under Uncertainty: Heuristics and Biases. Science, 185 (4157), 1124-1131.

Kapinus L., Rozumei S., Semenenko K. (2014). Osoblyvosti marketynhovoi zbutovoi polityky pidpryiemstva $\mathrm{v}$ merezhi Internet [Marketing sales policy of the enterprise on the Internet]. AIC Economics and Management, 2 (115), 68-72.

Kapinus, L.V., Skryhun, N.P. (2014). Development of electronic banking technologies in Ukraine. Economic Annals-XXI, 3-4 (1), 55-58.

Kapinus, L. (2021). Typizatsiia povedinky pidpryiemstv v suchasnykh umovakh. [Typization of behavior of enterprises in modern conditions]. https://cutt.ly/ansxYVl.

Kaplenko, H.V. (2005). Formuvannia ekonomichnoi povedinky pidpryiemstv [Formation of economic behavior of enterprises], Lviv, 20.

Karachyna, N.P. (2009). Udoskonalennia protsesu formuvannia ekonomichnoi povedinky pidpryiemstva [Improving the process of forming the economic behavior of the enterprise]. Bulletin of the National university «Lviv Polytechnic». Series: Problems of Economics and Management, 640, 285-290.

Katana, C. (1951). Psyhological Analysis of Economic Behavior. NY: McCrow-Hill.

Korytko, T.Iu (2018). Motives and methods of motivation of investment activity of the enterprise. Economic Herald of the Donbass, 2 (52), 201-205. 
Kubiniy, N., Marhitich, V., Kosovilka, T. (2020). Modern Content of Strategic Regional Development Potential. Economics and Business. Referential and Reviewed International ScientificAnalytical Journal, 1. https://cutt.ly/hjBG3Lm

Kudinova, A.V. (2004). Pidpryiemnytska povedinka: sutnist ta determinanty yii evoliutsii [Entrepreneurial behavior: the essence and determinants of its evolution]. Actual problems of economics, 4, 104-111.

Levin, J., Mildrom, P. (2010). Online Advertising: Heterogeneity and and Conflation in Market Design. American Economic Review Papers and Proceedings, 100, 603-607. DOI: 10.1257/aer.100.2.603.

Malysh, O.M. (2006). Managerial Economics of Market Behavior of an Enterprise (on the example of woolen industry enterprises in Ukraine), Ph.D. of Science (Economics) Thesis, Economics, Organization and Management of Enterprises, Vadim Hetman Kyiv National University of Economics, Kyiv.

Marinov, M., Todorova, L. (2020). Effects of the COVID - 19 Impact on the Tourism Sector in Bulgaria. Izvestia Journal of the Union of Scientists - Varna. Economic Sciences Series, 9(2), pp.6875. DOI: https://doi.org/10.36997/IJUSV-ESS/2020.9.2.68

Mokliak, M.V., Bondarenko, Yu.E., Fedorenko, O.V. (2015). Problemy vprovadzhennia ta upravlinnia marketynhovoiu diialnistiu na ukraïnskykh pidpryiemstvakh [Problems of implementation and management of marketing activities at Ukrainian enterprises]. Global and National Problems of Economy, 3, 366-369.

Orekhova, T., Dubel, M. (2018). The influence of digitalization process on the electronic commerce development in Ukraine. Economics and Organization of Management, 4 (32). DOI 10.31558/2307-2318.2018.4.2

Pavlov, O., Kulakivska, T., Samofatova, V. (2016). Sotsialna, povedinkova, adaptyvna ekonomika: teoriia ta praktyka [Social, behavioral, adaptive economics: theory and practice]: monograph. Odesa: Astroprynt. 172 p.

Rachinger, M., Rauter, R., Müller C., Vorraber, W. and Schirgi, E. (2019). Digitalization and its influence on business model innovation. Journal of Manufacturing Technology Management, 30 (8), 1143-1160. https://doi.org/10.1108/JMTM-01-2018-0020

Samuliak, V.Iu. (2008). Formation of the system of the purposes of development of the machine-building enterprise. http://vlp.com.ua/files/18_28.pdf

Schwarzl, S., Grabovska, M. (2015). Online marketing strategies: the future is here. Journal of International Studies, 2 (8), 187-196. DOI: 10.14254/2071-8330.2015/8-2/16.

Small, G., Vorgan, G. (2008). Meet your iBrain. Scientific American Mind. 19 (5), $42-49$.

Solohub, S.M. (2001) Theoretical bases for choosing a strategy for the development of enterprises in the post-privatization period. Current problems of the economy, 11-12, 58-61.

Thaler, Richard H. (2017). Behavioral Economics. Journal of Political Economy, 125 (6), 1799-1805. https://doi.org/10.1086/694640.

The three main types of Internet users. https://cutt.ly/9ju11Dz

Ustenko, M., Ruskykh, A. (2019). Digitalization: the basis of enterprise competitiveness in the realities of the digital economy. The Bulletin of transport and industry economics, 68, 181-192.

Wallace, L. (2004). How Software Project Risk Affects Project Performance: An Investigation of the Dimensions of Risk and an Exploratory Model. Decision Sciences, 35, 289-321.

Walters, Dave. (2015). Behavioral Marketing. JumboMouse Labs, LLC. DOI: 10.1002/9781119170440.

Watrobski, J., Jankowski J., \& Ziemba, P. (2016). Multistage performance modelling in digital marketing management. Economics and sociology, 9(2), 101-119. DOI: 10.14254/2071789X.2016/9/2/7. 


\title{
ECONOMIC RELATIONS DEVELOPMENT INFLUENCED BY MODERN INFOCOMMUNICATIONS IN TERMS OF ECONOMIC AND SOCIAL TRANSFORMATION
}

\author{
Tetiana Neboha $^{1}$, Svetlana Suprunenko ${ }^{2}$ \\ ${ }^{1}$ Institute of market problems and economic-ecological research of National Academy of Science, \\ 29, Frantsuzskiy Boulevard, 65000, Odessa, Ukraine \\ ${ }^{2}$ University of State Fiscal Service of Ukraine, 31, Universytetska str., 08201 Irpin, Kyiv region, Ukraine \\ ORCID ID (D): ${ }^{10000-0002-5025-7299,}, \underline{20000-0002-4585-3440}$
}

\begin{abstract}
The study analyzes the prerequisites of the information society formation, which focuses on the new knowledge and ideas production, based on the advanced technologies and infocommunications use. It is established that the information society formation involves ensuring a high level of information and communication technologies development and the telecommunications market in general, which serve as the material basis of the transformational socio-economic processes. The importance of a detailed target program implementation for information society formation to overcome the significant lag in the communications and telecommunications technologies development in Ukraine from world standards has been proved. Theoretical issues of a intellectual activity potential object transformation process into an object of intellectual property of modern enterprises are considered, and problems of intellectual property commercialization in Ukraine are identified, among which the most important are legal framework development, creation and approval of Intellectual Property Code and infrastructure of results of scientific and technical activities in production implementation.The issue of an innovative product commercialization as a functional component of the national economy innovation infrastructure is considered. The stages of the algorithm for determining the directions of public administration improvement in the innovation sphere are formed. It is determined that Ukraine's innovation policy should be based on such important components as the permanent process of the innovation management system improving, legislative consolidation of opportunities for national science and business integration, development of innovation culture based on European experience, and development of the social environment for the ecological innovations implementation.
\end{abstract}

\section{INTRODUCTION}

One of the strategic objectives of Ukraine's economic policy is to increase the economy competitiveness, the solution of which involves the introduction of an innovative model of development. The rapid development of the infocommunication sphere affects global changes in the organization forms of economic entities relations and radically changes traditional economic relations, leading to the formation of a new socio-economic environment. Industrial society is being replaced by post-industrial, or electronic-digital, development of which is based on the formation of a global information space. At the same time, the processes of informatization and digitalization permeate all spheres of national economies.

In the economy formation conditions of innovative type results of intellectual activity and the innovations based on them act as the basic source of well-being. The use and implementation of scientific and technical achievements are directly related to the formation and effective operation of innovation infrastructure, and the system of patenting, licensing, consulting on protection, defense, evaluation and intellectual property use and commercialization of scientific results is one of the important national innovation infrastructure components.

\section{METHODS}

The theoretical and methodological basis of the study were the works of theoretical scientists on the development of economic relations under the influence of modern infocommunications and various innovation aspects of the national economy. 
To solve the problems of scientific research, general scientific theoretical and special methods of scientific cognition are used: analysis and synthesis, grouping and generalization, comparativehistorical, as well as: formal-logical, comparative analysis, statistical.

\section{THE ROLE OF THE INFOCOMMUNICATION SPHERE IN THE PROCESS OF THE INFORMATION SOCIETY FORMATION.}

Modern development of civilization is characterized by transformational processes - the information society formation, in which the main resources and factors of development are knowledge and information. "Today, the role of knowledge in economic development is growing, outpacing the means of production and natural resources. Thus, according to the World Bank, physical capital in the modern economy forms $16 \%$ of the country's total wealth, natural - $20 \%$, and human - 64\%. In countries such as Japan and Germany, the share of human capital reaches $80 \% "$ (Fedulova, 2017).

The July G8 summit was adopted by the Okinawa Charter on the Global Information Society in 2020. This document defines the main directions, ways and priorities of information society development. According to the Charter, one of the most important factors influencing the formation of society in the 21 st century will be information and communication technologies. It is noted that the information society is a level in the development of modern civilization, characterized by increasing the role of information and knowledge in society, increasing the share of infocommunications, information products and services in gross domestic product (GDP), creating a global information space that provides effective information interaction people, their access to global information resources and meeting their social and personal needs for information products and services (Rada, 2020).

The competitiveness of countries in the world market, their position in the world economy is stronger, the more actively they use the decisive factor of economic development - information potential as a set of tools, methods and techniques of using information resources.

The primary feature of the information society is the availability of information for each individual at any time, as well as its production in sufficient quantities necessary for society. This function is performed by communication through the quantitative accumulation of traditional means that have developed in the early twentieth century. The formation of the information society is due to the rapid development of functional information networks, which "organically connect people, institutions and society", and "their development adds to social processes, and especially the economy, more balanced" (Galchinsky, (2007). One of the founders and the largest shareholder of Microsoft, Bill Gates, notes the importance of information in modern society, that the competitiveness of individual firms, and therefore states, directly depends on the speed and timeliness of its transmission: "I firmly believe in a simple thing: the most reliable way to distinguish your company from competitors, to break away from the crowd of persecutors - is to organize the work with information. It is how you gather, organize and use information that determines whether you win or lose. "The author notes that modern information flows, which allow you to properly organize business processes and develop the right strategies, are impossible without the "electronic nervous system". "Only those companies will win that will be able to implement a" high-grade electronic "system - one that ensures the smooth flow of information for the intensive continuous development of the company's intelligence." It is important to note that this "electronic nervous system" can be created only with a high level of development in the country of an important component of the country's infrastructure - the communications industry. It is the infrastructure, which is based on information flows, will become the "nail of the program" in the XXI century (Gates, 2001).

Properties, composition and characteristics of communication services, their role in building an information society are considered in V.M. Hranaturov's book "Management of connect services". We support the author's statement that "information and communication technologies are a modern lever that provides an opportunity to transform development strategies; a tool that can be used in almost all industries, as well as the latest and most powerful resource for economic growth ... " (Hranaturov, Lytovchenko, 2010). Some authors define the degree of construction of the information 
society in Ukraine as "the initial stage of formation of the information society" (Pryhoda, 2000), or argue that Ukraine "corresponds to the average, compared to other countries, the level of information society" (Mykhailovska, 2009).

The unresolved components of the problem can be assumed the consideration of transformational processes in the economy, the changing role of human in the social production process, which focuses mainly on generating new knowledge, as well as the new material basis formation of modern society.

Telecommunications and information technology occupy a key place in the structure of the world economy. "... Modern communication technologies (means of communication) not only serve production, but also directly integrate into it, because they are one of the single technological process links, a necessary element of productive forces" (Hranaturov, Lytovchenko, 2010). The main types of telecommunication services include telephone communication - local, long distance, international, telegraph, mobile, computer, satellite; conductive speech; transmission, receipt of television and radio programs; radio communication. In the flow of scientific and technological revolution of the late XX and early XXI centuries. the communications industry has undergone not only quantitative but also qualitative changes. Improving and increasing the actual means of transmission that can ensure the timely transmission of information of any complexity, has led to the replenishment of the field of communication information and communication technologies (ICT), designed to penetrate into all areas of production and qualitatively transform them. Under the influence of modern ICT there is a radical change in the role of human and his main - labor activity, because it comes from the direct process of production and becomes only the subject of its management. In this regard, the social function of the communications industry is qualitatively changing. Intensive development of communication at the end of the XIX century and especially in the XX century showed that this area of activity has become a "general condition of the social production process" at the global level, which covers all industries and all social structures.

Today, the theory of the issue affirms the position that modern communication, stimulating economic and social transformations, is not only a mean of transmitting information, but also the material basis for the formation and functioning of the information society as a holistic social entity. This point of view was first substantiated in the work of I.V. Pusenkova, who wrote: "In the second half of XX century in world production the connection is based on the general structure of the sectoral social division of labor and production. It ... begins to occupy a place in the structure of social production, which creates a priority provision as a material basis for interpersonal and industrial communication. ... It is communication that becomes the basis of all social structures management" (Pusenkova, 2001). This view is supported and developed by a number of other authors. So T.E. Tikhanova writes: "The material base of the information society in its mature state are communication systems and information technology, because they, as means of accumulation, processing, transmission and information exchange, provide services necessary for the basic human activities of society ..., and the fundamental function of the modern communication systems development and information technologies is to form the structural elements of the information society material base and the gradual replacement of the modern economy industrial base" (Tykhanova, 2008).

Fully sharing the position on the function of modern communication as a material basis for the formation and the information society development, we consider it possible to critically review a number of basic economic concepts and assess the state of Ukraine's economy on its path to transformation into the information society. Let's consider these questions in more detail.

Transformational changes in social relations and changes in the material basis of production are simultaneously accompanied by the activation of qualitatively new production factors and its resources. Machine production and cooperation of joint labor of hired workers, being the material base and the main factor in the development of spontaneous market relations of free competition, have resources in the form of land, labor and capital. Information and -based on it knowledge are the determining factors of development and basic resources of information economy (IE) as a top-level management system based on advanced information and communication technologies (ICT) and 
modern means of communication. The key carrier of IE resources is the creative activity of employees as "universally developed" individuals (Pusenkova, 2001). In this regard, there is a restructuring of the content of the basic concepts of social production. This is especially true of the workforce. The concept of labor as the ability to work, which is a set of physical and spiritual abilities possessed by the body and which are put into action by him every time he produces consumer values, is subject to modification.

In the information society, an important role is played by a creative person - the owner of knowledge, intelligence, experience, creativity, with his willingness to lifelong learning, because in the "knowledge society" a person who has this or that knowledge will need to update them every four-five years, otherwise they will become hopelessly obsolete" (Fedulova, 2017). P. Drucker introduced the terms "knowledge work" and "knowledge worker". In his work "Post-Capitalist Society" he set out his views on the transition to a knowledge society where "... the main economic resource" will no longer be capital, natural resources or labor. It is and will be knowledge, and the main role will be played by "the worker who creates knowledge" (Drucker, 1994). Since a creative person is a carrier of basic resources "information - intelligence - knowledge", the owner of knowledge, intelligence, experience, creativity is a great value in the information society. "Human becomes the main value and measure of all things and events" (Tykhanova, 2008)."Human as a person himself creates and builds his relationship of communication, he manages them. Communication creates the material conditions of this management, it is through communication that it can be carried out both in production and in all spheres of social activity" (Pusenkova, 2001).

Significant changes are taking place in the field of dissemination of information itself. Today we can observe how much information flows are increasing, as well as huge amounts of new knowledge appear in almost all spheres of human life, which is inevitably associated with the global information technology revolution that is taking place. In these conditions, the individual, in order to meet the new conditions of modern society, must constantly work on their education - to gain new knowledge and improve those that he already has. It is important to note that the information itself, without human knowledge about the method of its application, ie one that does not have the ability to its practical application, is not of economic value. In other words, not all information is knowledge that can act as a factor of production.

In transformational conditions, the understanding of such an economic category as a commodity also changes, because the results of creative, intellectual work do not take the form of value. Abstract labor, which is the only content, the substance of value, is different from labor, which creates knowledge. Creative work for the creation of new knowledge cannot be reduced to the socially necessary costs of abstract labor, which underlie value. These labor costs cannot be reduced to the average socially necessary labor costs. They have a different level of quality, include a global information component that cannot be accounted for energy costs and which are subjective, unique.

Thus, the product of the worker's labor who creates knowledge cannot have the property of value, which was the postulate of the classics. The result of creative work enters the market and is sold at a price that includes not the costs associated with the development of new knowledge, but at a price based on the estimated income from the use of this knowledge.

The socio-economic content of other categories of modern market relations is also changing. If we consider the level of development of modern communication in the form of information services in Ukraine, we should use a comparative analysis of market indicators in this area. Qualitative transformations of modern economic relations in Ukraine, as well as all over the world, are due to the growing role of the infocommunication sphere in all aspects of social activity. There is a direct connection between the economic development of the country and the development of information and telecommunication technologies.

Considering the market state of the Ukrainian communication services in the context of the Internet speed indicator which provides stability of work performance with use of a network, it is necessary to note its negative tendency in Ukraine. Thus, according to the results of the Cable survey on Internet speed in 207 countries in 2019, Ukraine ranked 81st, worsening this figure by 24 points 
compared to 2018. The leaders of the ranking are Taiwan, Singapore, the island nation of Jersey and Sweden (Konkurent. 2020).

However, research shows that in this area with the absolute growth of revenues from the provision of services there is a significant decrease in their growth rates. The negative trends in the development of the communications industry in Ukraine are also evidenced by the significant lag of the growth index of communications services revenues from the country's GDP growth index since 2006. From this period, there is a decrease in the share of the communications industry in GDP (see Table 1).

Data, given in Table 1, show that the decline in income growth of the infocommunication sector of Ukraine coincides with the decline in the GDP growth index and falls on 2009, from 2009 to 2011 there is an increase in both indicators, in 2012 the decline to 7.0 and 4.0, respectively.

Table 1. Data on the ratio of growth rates of communications revenues and nominal GDP of Ukraine for the period from 2008 to 2019

\begin{tabular}{|c|c|c|}
\hline Years & Growth rates of GDP, & $\begin{array}{c}\text { Growth rates of revenues from the provision } \\
\text { of infocommunication services, } \%\end{array}$ \\
\hline 1 & 2 & 3 \\
\hline 2008 & 31,5 & 15,6 \\
\hline 2009 & $-3,7$ & 0,4 \\
\hline 2010 & 18,5 & 2,5 \\
\hline 2011 & 21,6 & 6,0 \\
\hline 2012 & 7,0 & 4,0 \\
\hline 2013 & 3,3 & 0,4 \\
\hline 2014 & 7,7 & $-0,1$ \\
\hline 2015 & 26,3 & 6,6 \\
\hline 2016 & 20,4 & 10,8 \\
\hline 2017 & 25,2 & 6,7 \\
\hline 2018 & 19,3 & 9,9 \\
\hline 2019 & 11,7 & $-1,3$ \\
\hline
\end{tabular}

Source: prepared by the author according to (Ukrstat)

This situation corresponds to the global trend: the advanced development of the infocommunication sphere has a positive effect on the growth of the country's economy. In 2019, there is a decline in revenues from the provision of communications services compared to 2018 by 1.3 percent, while GDP grew by 11.7 percent.

The above-mentioned directions of changes brought about by the development of the infocommunication sphere in economic development concern the essence of production and social relations of the existing society. Since we are talking about qualitative changes in these relations, it is legitimate to interpret them as ways of transformational transition to a post-industrial, ie information society.

At the same time, despite the fact that Ukraine has declared the construction of an information society (Ukrstat, 2007), there are no positive trends in this direction in the country. Statistical observations of the information society formation in some countries are carried out by a number of international organizations through the use of various indices. The International Data Corporation (IDC), an information technology market research firm, has proposed the Information Society Index (ISI). As of 2020, the IDC website provides index values for 134 countries. Ukraine ranks 64th in this ranking. The top positions in this ranking are occupied by Sweden and Denmark, Singapore and the Netherlands are respectively 3rd and 5th place, Switzerland - 4th (NRI, 2020).

The deterioration of the ICT sector in Ukraine's economy is also confirmed by the ICT IDI index - a comprehensive indicator of the development of information and communication technologies, developed by the International Telecommunication Union (Table 2). 
Table 2. IDI index of information and communication technology development in some countries

\begin{tabular}{|c|c|c|c|c|}
\hline \multirow{2}{*}{ Country } & \multicolumn{2}{|c|}{2017} & \multicolumn{2}{|c|}{2012 (for comparison - change in 5 years) } \\
\hline & Rating & Index & Rating & Index \\
\hline Iceland & 1 & 8,80 & 3 & 8,36 \\
\hline Republic of Korea & 2 & 8,78 & 1 & 8,57 \\
\hline Switzerland & 3 & 8,68 & \multicolumn{2}{|c|}{ was not in the top 10} \\
\hline Denmark & 4 & 8,66 & 4 & 8,35 \\
\hline Great Britain & 5 & 8,53 & 8 & 7,98 \\
\hline Hong Kong, China & 6 & 8,61 & 10 & 7,92 \\
\hline Netherlands & 7 & 8,49 & 7 & 8,00 \\
\hline Norway & 8 & 8,47 & 6 & 8,13 \\
\hline Luxembourg & 9 & 8,47 & 9 & 7,93 \\
\hline Japan & 10 & 8,43 & \multicolumn{2}{|c|}{ was not in the top 10} \\
\hline$\ldots$ & $\ldots$ & $\ldots$ & $\ldots$ & $\ldots$ \\
\hline Ukraine & 79 & 5,62 & 68 & 4,64 \\
\hline
\end{tabular}

Source: prepared by the author on the basis of data (ITU, 2017)

The number of business entities in the field of infocommunications is constantly increasing and in 2018 is 174,622 units, which is 50\% more than in 2015 (Ukrstat, 2019). At the same time, the volume of sold products increased by $93.49 \%$, and the number of employees in the sector is 331.6 thousand people in 2018 (20.54\% more than in 2015) (Table 39).

Table 3. The main structural indicators of information and telecommunications

\begin{tabular}{|c|c|c|c|c|c|c|c|}
\hline \multirow[b]{2}{*}{ Indexes } & \multicolumn{4}{|c|}{ Years } & \multicolumn{3}{|c|}{ Growth rates, $\%$} \\
\hline & 2015 & 2016 & 2017 & 2018 & $\begin{array}{c}2016 / \\
2015\end{array}$ & $\begin{array}{c}2017 \\
/ 2016\end{array}$ & $\begin{array}{l}2018 \\
/ 2017\end{array}$ \\
\hline 1 & 2 & 3 & 4 & 5 & 6 & 7 & 8 \\
\hline $\begin{array}{l}\text { 1. GDP (in actual prices), } \\
\text { UAH million }\end{array}$ & 1988544 & 2385367 & 2983882 & 3558706 & 20,0 & 25,1 & 19,3 \\
\hline $\begin{array}{l}\text { 2. Sphere of information and } \\
\text { telecommunications, UAH } \\
\text { million }\end{array}$ & 72596 & 89268 & 110296 & 136960 & 23,0 & 23,6 & 24,2 \\
\hline $\begin{array}{l}\text { 3. The share of } \\
\text { communications and } \\
\text { informatization in GDP, } \%\end{array}$ & 3,65 & 3,74 & 3,70 & 3,85 & 0,09 & $-0,04$ & 0,15 \\
\hline $\begin{array}{l}\text { 4. Revenues from the } \\
\text { provision of services in the } \\
\text { field of telecommunications } \\
\text { and postal services, UAH } \\
\text { million }\end{array}$ & 55895,8 & 61911,2 & 66040,9 & 72564,7 & 10,8 & 6,7 & 9,9 \\
\hline $\begin{array}{l}\text { 5. Number of business entities, } \\
\text { units }\end{array}$ & 116136 & 129704 & 146909 & 174622 & 11,7 & 13,3 & 18,9 \\
\hline $\begin{array}{l}\text { 6. Volume of sold products, } \\
\text { UAH million }\end{array}$ & 141479,6 & 175050,9 & 216803,8 & 273742,2 & 23,7 & 23,9 & 26,3 \\
\hline $\begin{array}{l}\text { 7. Number of employees, } \\
\text { thousand people }\end{array}$ & 275,1 & 282,8 & 303,1 & 331,6 & 2,8 & 7,2 & 9,4 \\
\hline $\begin{array}{l}\text { 8. Personnel costs at } \\
\text { enterprises, UAH million }\end{array}$ & 15641,6 & 17093,8 & 22055,5 & 26531,8 & 9,3 & 29,0 & 20,3 \\
\hline $\begin{array}{l}\text { 9. Average monthly salary per } \\
\text { full-time employee, UAH }\end{array}$ & 7111,0 & 9530,0 & 12018,0 & 14276,0 & 34,0 & 26,1 & 18,8 \\
\hline
\end{tabular}

Source: prepared by the author according to (Ukrstat, 2019)

Revenues from the provision of services in the sector increase annually by about $9 \%$, while the share of the sector in GDP during the analyzed period increased by $0.2 \%$ and amounted to $3.85 \%$ in 2018. 
The Economist Intelligence Unit (EIU) together with the IBM Institute for Business Value developed an e-readiness rating. The rating of "e-readiness" reflects the state of the environment for e-business in the country, shows how effectively the Internet penetrates into the structure of society. This rating is determined on the basis of six criteria: access and infrastructure; the state of the ebusiness environment in the country; social, educational level; legal environment; public policy; readiness of consumers and businesses to use various Internet opportunities. This is an important criterion for the future competitiveness of the economy in the world economy and the possibility of creating a global information infrastructure as an organizational and technical basis of the information society. The ranking of 2019 includes 62 countries, and the criterion of electronic readiness (ereadiness) has received a new name - "digital competitiveness rating" ("digital competitiveness ranking"). The top positions in the 2019 rows ranking are occupied by the USA and Singapore. Ukraine in the ranking of "digital competitiveness rating" in 2019 is ranked 60th out of 62 countries (WDCR, 2020).

At the same time, it should be noted a positive trend regarding the process of digitalization in Ukraine. Thus, according to the United Nations study "E-Government Survey 2020", Ukraine ranks 69th among the countries of the world, improving this indicator by 13 points compared to 2018 (United Nations, 2020).

Modification of economic relations under the influence of the infocommunication sphere creates conditions for the formation of new forms of social and economic relations. We are talking about the sharing economy. Such an economy is a complex system of social and economic relations concerning the use of temporarily free or surplus resources through sale, lease or exchange for material gain.

In 2010, Time magazine named the participatory economy one of 10 ideas that will change the world. And Pricewaterhouse Coopers analysts, who prepared a report for the European Commission in 2013, defined the participatory economy as an environment that brings together "companies that use business models based on providing access to something in peer-to-peer markets. The peer-to-peer model ( $\mathrm{P} 2 \mathrm{P})$ provides consumer participants in market conditions with the right to temporarily use (access) a resource that belongs to other participants (their analysts also refer to consumers), the company itself acts as an intermediary, which brings these entities together (Government, 2020).

Joint economics allows you to resolve the contradictions between limited resources (assets) on the one hand, and the availability of modern technological innovations that are actively generated and implemented in the market - on the other. That is, the "peer-to-peer" model, which underlies the functioning of the participatory economy, can be implemented only through the use of information and communication technologies. Examples of such business models are Kickstarter (crowdfunding platform - a collective investment fund), Uber Technologies Inc. (online taxi search service), BlaBlaCar (the largest online passenger search service), eBay Inc. (a company that provides online auction and online store services), Rekruitloop (a recruiting service that unites employers), and other companies that cover various areas, but their activities are based on the use of online platforms and mobile applications (Neboha, 2018).

According to Rachel Botsman, author of The Advent of the Age of Shared Consumption, the emergence and development of a participatory economy were driven by the following four factors:

- the presence of peer-to-peer (based on equality of participants) social networks and technologies that change the behavior of the population;

- the global economic crisis of 2008 (it was after 2008 that most of the well-known companies of the joint venture economy were established);

- environmental problems;

- revival of trust between people and efforts to help others (Botsman\&Rogers, 2010).

However, the idea of providing temporarily free resources or assets is not new. In the era of the emergence of market relations, this form of economic relations existed in the form of rent, lease or hired labor. Although the economy is called the economy of joint participation, the characteristics 
of capitalist relations remain - it is private property and wage labor. That is, despite the fact that the resources can be used by any member of society, these resources are not a collective form of ownership. Such provision of resources takes place on a temporary basis, while preserving the rights of private property and market conditions of exchange. The only difference is that the exchange of goods (services) takes the form of providing access to resources and is carried out indirectly through the use of Internet platforms or applications on smartphones.

The analysis of the development of economic relations in the conditions of economic and social transformations under the influence of modern infocommunications allowed to draw the following conclusions:

1. Information society is a society focused on the production of new knowledge, ideas, in which high-tech competitive products are made on the basis of the use of advanced technologies and infocommunications. In such a society, the main value is a creative person who has creative abilities, experience and who is the bearer of modern basic resources "information - intelligence - knowledge".

2. The formation of the information society involves ensuring a high level of development of information and communication technologies and the telecommunications market in general, which perform the function of the material basis of transformational socio-economic processes.

3 . The analysis showed that currently the market of communication services in Ukraine is in crisis, and the level of development of information and telecommunications technologies is significantly lower than foreign countries.

4. Overcoming the significant lag in the development of communications and telecommunications technologies of Ukraine from the world indicators of these processes is possible only on the basis of the implementation of a detailed target program for building the information society of our country.

5. The strategy for building the information society, defined in the Law of Ukraine "On the Basic Principles of Information Society Development in Ukraine for 2007-2015", is declarative in nature. The country lacks a targeted program, statistical observations and monitoring of the process of formation of the information society.

6. Since the construction of the information society cannot take place without the highly developed sphere of telecommunications and information technologies, as well as the corresponding growth of market demand for them, it is too early to talk about the process of formation of this society in Ukraine. Only the preconditions of this process are created.

7. The solution of these problems is on the way to the development of system management in the field of telecommunications, stimulating the process of introducing innovative technologies in all areas of production and circulation. The unresolved issue of this problem, which requires further research, is the development of a targeted state program for the development of ICT in Ukraine and overcoming its inequality with the developed countries of the modern world.

8. The economy of joint participation allows society to obtain significant benefits, among which the main - the efficient use of resources and assets; creation of a flexible employment system, including remote; providing new types of services and intensifying the expansion of supply. Such an economy brings to society a significant positive external effect in the form of increasing globalization, the spread of the Internet, which is manifested in the development of exchange of resources and assets, based on their joint consumption. In addition, positive trends will be further manifested through a set of measures aimed at protecting the environment and efficient use of natural resources.

\section{THEORETICAL ISSUES OF THE PROCESS OF TRANSFORMATION OF A POTENTIAL OBJECT OF INTELLECTUAL ACTIVITY INTO AN OBJECT OF INTELLECTUAL PROPERTY OF MODERN ENTERPRISES}

The most important feature of the development of the modern world economy is its entry into the era of an innovative economy, where not only natural resources, but also the results of intellectual activity and innovations based on them become the leading source of prosperity. There is a tendency to shift the main attention in the organization and management of enterprises from the sphere of production to the sphere of innovations, where intellectual property (IP), being the most important 
factor ensuring the strength of the market positions of its owners, is considered as the main competitive advantage that allows business entities to increase the efficiency of their activities.

As a result, there have been changes in the conditions and principles of behavior of enterprises in the market in the world. The results of the economic activity of modern enterprises are increasingly dependent on the funds allocated by them for R\&D and the protection of the intellectual property created in this case. Fumio Kodama, comparing industrial and modern enterprise management systems, notes that earlier the production formula could be defined as "capital + labor", now - as "capital + R\&D" (Zavlin, 2001).

A significant contribution to the theoretical development of property relations, the problem of socialization and democratization of property relations, was made by research in the works of A. Alchyan (Alchian, 1965), G. Becker (Becker, 1968). J. Hodgson (Hodgson, 2001), Stigler G.J. (Stigler, 1961), Kapelyushnikova R.I. (Kapelyushnikov, 1990), Inozemtseva V.L. (Inozemcev, 2000), and many others.

In the scientific literature, intellectual property is usually viewed from the point of view of law. There are practically no works devoted to the systematic study of the economic content of intellectual property and the process of transformation of a potential object of intellectual activity into an object of intellectual property. However, any legal constructions in relation to economic forms must be built on a solid foundation of the economic justification of their essence.

Thus, the existing theoretical and methodological foundations of intellectual property and its commercialization require further development and generalization.

At the end of the twentieth century, changes in the social life of mankind began to appear quite clearly, and today we observe how creative activity and innovation are turning into the main factor of progress. The processes of socialization of labor and the growth of its productivity, described in classical Marxist works, led to the emergence of a new quality of social activity. In practice, the terms of this new quality are confirmed. The content of labor is changing: the industrial reproductive labor of a person, as an appendage of a machine, is supplanted by his creative activity. Today, in industrially developed countries, creative work is becoming potentially massive and represents the main wealth and driving force of social progress. Among the properties that fundamentally distinguish creative labor from reproductive labor, the most important is the transformation of the self-development of the individual (the subject of creative activity) and the creation of cultural values into the main internal (not alienated from man) stimulus for the activity of a creative person. This situation is qualitatively different from reproductive labor, the purpose and most important stimulus of which is an external (in relation to the employee) material product (goods, money). As such, creative labor is, in principle, not alienated from its subject.

Today we can observe trends in the nature of the means of production, the subject and the result of labor. And the first, and the second, and the third are information, cultural and natural values. The most significant for progressive development are qualitatively new resources, the peculiarity of which is that, unlike the previous ones, reproducible and limited, they, while being unique at the same time, have a universal character - these are new ideas, know-how, etc.

Changes in the content of labor and production naturally lead to the fact that the structure of social production changes. It is not the ownership of the means of production that comes to the fore, but human capital, one of the important elements of which is intellectual property.

In addition to the fact that the structure of social production is changing, today we can observe the destruction of the foundations of private property, which is based on the formation of ownership of information and knowledge. As Western scholars note, "... the movement of information challenges the boundaries of exclusive and individual property" (Hodgson, 2001).

First, this is due to the fact that knowledge and information are inseparably linked with those who produce them: the separation of capital from labor becomes impossible. Second, even if it is sold, knowledge remains with its producer, and therefore knowledge is a "collective good". As a result, in an economy with significant information flows, it is not always possible to establish clear ownership boundaries. 
This radically changes property relations, leads to the fact that "in developed countries there are societies in which a person does not depend, to the extent that it took place in an industrial civilization, on the ownership of the means of production by the representatives of the ruling class, since the main knowledge that is inseparable from a person becomes them, and the conditions for their development and application are becoming more and more accessible" (Inozemcev, 2000).

As you know, in Latin the word "intellect" means the mind, reason, reason, or in general "the thinking abilities of a person." The term "property" means "production relations, expressing a certain form of appropriation." Property relations as volitional relations are relations of ownership, disposal, use. These are legal forms (frameworks) within which or through which economic relations are manifested (Pusenkova,1997).

Thus, intellectual property, as an economic category, expresses the economic relations between people regarding the nature and form of appropriation, possession, disposal, use of the results of intellectual activity.

In the light of the legal system, the intellectual power has been declared not so long ago. 23 birch 1883 p. Bula signed by Parizka convention for the protection of industrial power, at 1891 p. Made out to please madrid about the international restoration of signs. The crumbs earlier were laid by the Bernsk Convention for the protection of literary and artistic creations. In 1967, the Convention on Falling asleep of the All-Holy Organization of Intellectual Power was introduced in Stockholm by the concept of intellectual power. Bachennya of All-social organization of intellectual power of the field in the fact that intellectual power is an important tool of economic, social and cultural development of all countries (WIPO, 2019).

Intellectual power vvazhayutsya rights to the results of the rosy activity of the people, which is about the civil law in the part of the right of the skin volity, to corystuvatis and to be ordered by the results of one's own intellectual, creative. In the current legislation, it is necessary to share copyright and intellectual rights, industrial power and non-traditional intellectual power.

Intellectual power, as an economic category, depends on the economy among people due to the nature of the strong practice and the size of the vitrate, tobto varity. Formuvannya institutu intelektualnoï vlasnosti pov'yazane of low ekonomichnih chinnikiv to yakih slid vidnesti - podil pratsi, vihid Lyudin of bezposerednogo Process virobnitstva, vidokremlennya intelektualnoï pratsi Especially in view diyalnosti, peretvorennya produktiv intelektualnoï pratsi in goods zaluchennya produktiv intelektualnoï pratsi in rinkovy tovaroobig. Being the day of this product, the economy is intertwined with the legal form of the law, volodinnya, ordering, correcting by the results of intellectual efficiency.

In the minds of prompting the informational support, in which the largest resources are available information and knowledge, the intellectual power is converted into one of the most common products. The commercialization of intellectual power is more practical. In this day, the commercialization of intellectual power has become the basis of the current strategy for the development of enterprises in all developed countries (Shmygol et al., 2020; Koval et al., 2020).

It should be stated that historically the main factors that influenced the formation of the institution of intellectual property were:

- division of labor;

- a person's exit from the direct production process;

- isolation of intellectual labor into a special type of activity;

- transformation of products of intellectual labor into goods;

- involvement of products of intellectual labor in the market turnover.

The results of human intellectual activity, representing new knowledge or information, have always been one of the factors for the acquisition and augmentation of capital. This made them the subject of special interest in society. However, the legal relationship regarding new knowledge has essential features. The owner of new knowledge or information has significant advantages for himself as long as this information does not become the property of others.

As soon as new information becomes publicly available, the advantages of its original owner over others disappear. Owning knowledge or information alone is often difficult due to their 
intangible nature. It is almost impossible to protect them from someone else's encroachment with ordinary material means. The difficulties of the monopoly of knowledge or information are also associated with the fact that the appearance of a new product on the market accelerates the process of obtaining a similar result by other people independently, as a result of their own creative, intellectual activity. When a competitor appears on the market, the advantages of the first-owner also sharply decrease. Thus, it is not so easy for the original owner to realize his benefits from the acquisition of new knowledge or information.

In the conditions of the modern post-industrial economy, intellectual property is the key to economic freedom. The owner of knowledge, intelligence, experience, creativity, being a great value for the company, has his own economic interest in the results of their use.

In this regard, it is of particular importance to study foreign experience in the field of legal and economic regulation in the field of intellectual property, which is actually the genetic basis of modern high-tech business.

It is characteristic that in the last decade, in most developed countries of the world, there has been a tendency to consolidate intellectual property rights, even with funding of research at the expense of the state, directly to universities and other non-profit scientific organizations.

The most striking example is the United States. Until the beginning of the 80s. of the last century, patents for the results of university research, funded by the state, were assigned to the government, which did not have a special mechanism for their commercialization. It is no coincidence that by 1978 the federal government was able to license only $4 \%$ of the 28,000 patents it owned. The well-known Bay-Dole Law, adopted in the United States in 1980, dramatically changed this situation in the American high-tech industry, as it forced universities to patent the results of their research, as well as to commercialize them. Since the adoption of this law, there has been a sharp surge in innovation in the United States. Stagnation 1960-1970s was replaced by a rapid growth in the number of patents granted annually: in 20 years, their number has more than doubled. The Bay-Dole Act not only allowed federal-funded intellectual property to be transferred to universities, but also allowed the exclusive licensing of inventions, which is a key condition for their commercialization. Such an integrated approach gave positive economic results (Huriev, 2006).

Currently, the commercialization of IPOs has become the basis of the modern strategy for the development of enterprises in all developed countries. The process of transferring intellectual property rights is at the heart of any innovation process and is a very important and complex issue. However, in Ukraine, the issues of transfer of rights to use intellectual property are not legally prescribed. Unfortunately, the laws currently in force in Ukraine "On the Protection of Rights to Inventions and Utility Models" and "On the Protection of Rights to Industrial Designs" do not provide for adequate protection of the authors of inventions. For example, they indicate that the IP belongs not to the author, but to the Ministry of Education and Science of Ukraine.

Foreign experience can be useful for Ukraine to develop a common approach to the problem of securing rights to objects of intellectual property (OIP), and above all in terms of issues related to its commercialization.

The commercialization of IPOs is their practical use for the purpose of making a profit, for which it is necessary to timely transform the results of intellectual activity into commercial products and services that are in demand on the market. In the commercialization of IPO, the result of intellectual activity is transformed into a product that is attractive to a potential consumer. This process is especially difficult and time consuming for the results of fundamental and exploratory research, which are not directly aimed at solving specific practical problems. In this regard, this new knowledge needs to be transformed in such a way that it becomes visible and attractive to those who are interested in it.

The commercialization of the results of intellectual activity can be represented as a sequence of stages during which a potential object of intellectual activity is transformed into an object of intellectual property, which can later be used in commercial activities.

1 st stage. Creation of an idea based on existing information. 
On its basis, which the developer has (accumulated knowledge, some practical need, or ideas for the development of a fundamentally new product based on an operating model), a certain idea, hypothesis, concept basis is formed.

2nd stage. Formation of an object of intellectual activity based on research and development.

As part of the transition to the second stage, an object of intellectual activity is formed, that is, the information available at the initial stage is embodied in a particular result. Fundamental, exploratory, applied research and development work is carried out, as a result of which a discovery prototype, utility model or industrial design appears.

3rd stage. Formation of an object of intellectual property. The object of intellectual activity can be protected either within the framework of copyright, or within the framework of patent law, or as an object of trade secret. It should be noted that in Ukraine the term for the examination of applications for solid inventions and the issuance of subsequent patents is a long period (up to 4-5 years), which cannot but have a negative effect on the process of commercialization of the results of intellectual activity. In addition, the country lacks state-level training for patent specialists.

4th stage. Inclusion in the structure of the property of the enterprise. After registration of intellectual property rights, the intellectual property object is assessed and placed on the balance sheet for subsequent accounting. It should be borne in mind that the specificity of the IPO is that it is not the products of intellectual activity that enter the market, but the rights to them. Accordingly, the cost of these products acts as the cost of rights, and the objects of purchase and sale are documents of title confirming the right to use the property.

The valuation of intangible assets, which include the IPO, must be approached differently than the valuation of tangible assets. Their true value lies in the income they can generate. The value of intellectual property is considered to lie in its use, but not in the costs associated with its development. The introduction of intangible assets into economic circulation and their effective management allows not only protecting the business, but also increasing the value of the enterprise by increasing the size of assets, as well as providing it with additional sources of cash receipts through the sale of licenses. For an investor who has invested his money in stocks, the most important source of value is the company's ability to generate cash flows through the use of intangible assets.

5th stage. Using intellectual capital. At this stage, the IPO is directly commercialized.

Intellectual capital can generate income for its owner in three main ways.

First, the owner can use all intellectual property rights himself, using the intellectual capital as an intangible asset of the enterprise. The owner of the IP independently ensures the release of competitive and high-tech products; accordingly, all income from the potential market will belong to him.

Secondly, the owner can transfer the rights to the IPO to another person. In this case, the IPO will be a commodity, and the owner will lose the opportunity to receive full-scale potential income from the IPO.

Thirdly, the owner can use one of the most important properties of the IPO: the rights to use the IPO are able to participate in the exchange any number of times, each time bringing a high income to the owner of the IPO, remaining even in the conditions of exchange in the partial ownership of the owner. Thus, the copyright holder receives income both from the sale of the IPO and from its use.

It is clear that the most profitable, but also the most risky way of IPO commercialization is independent use, when the patent holder himself carries out the process of IPO commercialization on the market. As a rule, in this case there is a vertical transfer of technology, that is, the sale of goods created on the basis of IPO to a direct buyer. But independent commercialization is also characterized by large financial investments and increased risks.

Important elements contributing to the successful commercialization of IPOs include:

-information support of all stages of the innovation cycle;

- taking into account the economic and social factors in the use of IPOs, as well as modern trends in business and economics;

-the effectiveness of marketing research;

- close interaction of science, industry and the market. 
The process of transferring the rights of intellectual power to an important warehouse innovation process is even more important and not easy to eat. In Ukraine, however, the transfer of rights to intellectual power in Ukraine is not spelled out in the legislation. It is a pity that the laws "On the protection of rights to wine and brown models", "On the protection of rights to promises" in Ukraine do not transfer the authors' worthy authors to winners. For example, it is stated in them that the intellectual power is not due to the author, but to the Ministry of Education and Science of Ukraine. Unimportant for those who are interested in Ukraine in a high level of development of science and in bagatokh galuzy the knowledge of the new priority of Ukrainian science schools, the part of the Ukrainian intellectual power to gain power. The very commercialization of intellectual power is a new phenomenon for Ukraine. The country has a lot of infrastructure for marketing campaigns, the production of food-propositions based on technology, which is not very well-suited to the mechanism of assessment and to the source of intellectual power.

Low level of commercialization of intellectual power in Ukraine of the increase in advancing factors:

- the quickest part of innovative products in the general association of industrial products of Ukraine and the reduction of innovative activity of enterprises;

- a low drink on all kinds of scientific and technical outlets on the side of the state and the private sector;

- the nutritional assessment of intellectual power and information in the accounting area has not been regulated;

- the organization of the vital business for the development and commercialization of earth technologies;

- weak interaction between science and business;

- the visibility of a single core organ for nutrition of the OIV commercialization;

- trivial terms in the examination of applications for patents and wine passages: triviality in the examination of applications for wine passages is $1.5-3$ rock, and an application for signs for goods and services is considered $1.5-3.5$ rock;

- the number of qualified frames at the galuze of the commercialization of the OIV;

- incompleteness of the legislative base in the sphere of protection of the rights of intellectual power.

The assigned factor can be combined in two groups. The first is absolutely tied to the development of innovative processes and unrepentant innovations, and another - to the vads of the country's legislation on the basis of the establishment of legal norms, which regulates the future.

An analysis of the problems of commercialization of intellectual power in Ukraine is given to provide a direct understanding of the policy in the whole sphere. Find the middle ones:

- development of the legal framework, establishment and consolidation of the Code on Intellectual Power;

- stvorennya spetsialnih structures to funktsiy yakih bi included: conducting ekspertnoï otsinki komertsiynogo potentsialu, nadannya innovatsiynim rozrobkam finansovoï pidtrimki, prosuvannya ob'€ktiv intelektualnoï vlasnosti on vitchiznyani that inozemni Rink, zapobigannya nepravomirnogo vikoristannya that rozpovsyudzhennya ob'€ktiv intelektualnoï vlasnosti;

- the establishment of infrastructure in the implementation of the results of scientific and technical performance in the field of production;

- the establishment of the national training system and the promotion of the qualifications of the faculty of intellectual power.

Intellectual power is the most important factor that will preserve the market position of the masters, to be seen as the main competitor, as well as allowing the state-sponsored subjectivity of efficiency. As a result of the revision of the problems of commercialization of intellectual power, the root of the key subsystem of the national innovation system of the country - the innovative infrastructure of the country - should be left behind. 
The analysis of economic forms of relations in the field of intellectual activity and the mechanism of commercialization of the results of this activity made it possible to draw the following conclusions:

1. Intellectual property is at the heart of modern market relations. Intellectual property rights are reflected in the company's balance sheet as intangible assets, the value of which often exceeds the value of all tangible assets. The company's ability to protect its rights helps to reduce the risk of competitors copying the company's products and services, which means avoiding losses.

2. The introduction of intangible assets into economic circulation and their effective management makes it possible to more reliably protect the business, increase the value of the enterprise by increasing the size of assets, and also secure additional sources of cash receipts by selling licenses. Capitalization of intellectual potential creates the possibility of obtaining superprofits and accelerating innovation processes.

3. However, the commercial use of the results of intellectual activity, their effective implementation in a market economy is possible only when intellectual products have an objective market assessment, property rights are clearly specified and protected, when the infrastructure of innovation is developed.

4. Commercialization of the results of intellectual activity is a complex process consisting of a number of stages, during which a potential object of intellectual activity is transformed into an object of intellectual property.

5. World experience testifies to the significant role of the state in the process of commercialization of the results of intellectual activity, since only it can ensure that the interests of all subjects of intellectual property are taken into account.

6. The adopted legislation of Ukraine, regulating intellectual property relations, overlooked the fundamental issue of securing rights to $R \& D$ results financed from the state budget.

7. To speed up the processes of involving IP in the economic turnover, the legislation of Ukraine should contain provisions on securing the rights to the results of scientific and technical activities financed from the state budget for the performers of work (universities, state scientific laboratories, private firms). The next important step is the expansion of public-private partnerships at the pre-competitive stage. These partnerships use IP rights as a mechanism to encourage firms to collaborate with government research institutions.

8. In order to stimulate the interests of the private sector in the process of commercializing the results of intellectual activity, it is necessary to legislate the property rights to these objects created at the expense of public funds. It is also necessary to transfer the rights to dispose of IP objects from the state to the local (institutional) level of management.

9. It is advisable to use certain elements of foreign experience in organizing the research process - in particular, testing the practice of agreements on joint research between government organizations and industrial firms or small businesses. At the same time, the condition of transferring rights to the created IP objects to development organizations, industrial firms and small business organizations must be met.

\section{COMMERCIALIZATION OF AN INNOVATIVE PRODUCT AS A FUNCTIONAL COMPONENT OF THE INNOVATION INFRASTRUCTURE OF THE NATIONAL ECONOMY}

Innovation is the main priority of modern socio-economic policy of leading countries and all countries seeking to increase the competitiveness of their production, and the competitive advantages of modern companies are formed by a number of factors, the main of which is their ability to increase their technological and innovative potential and foreign innovation markets (Shmygol et al., 2020). Entering the market with innovation, the company turns it into an innovation through the process of its commercialization. Commercialization is an important functional component of a complex system of education - the innovation infrastructure of the national economy.

In foreign economics, many works are devoted to various aspects of innovation, among which the most interesting are the studies of Schumpeter J. (Schumpeter, 1982), Mensha G. (Mensh,1979), 
Drucker P. (Drucker, 2007), Fatkhutdinov R. (Fatkhutdinov, 2007), Geets V. (Geets, 1998), and others. Theoretical principles of formation and functioning of innovation infrastructure are reflected in the scientific works of foreign and domestic scientists, namely: Butenko O.I. Butenko, 2008), Tikhanova T.E. (Tikhanova, 2009), Shotik T.M. (Shotik, 2008), and others. Research of the organization of commercialization of an innovative product and the decision of problems of increase of efficiency of innovative activity of market subjects is devoted to research of Lyashenko O.M. ( Lyashenko, 2007), Naumova O.F., Zakharova A.A. (Naumov\&Zakharova. 2013), and others. . The works of these scientists explore the organization of the process of commercialization and transfer of innovations, the postulates of managing this process, the problems of efficiency of innovation activities of economic entities. At the same time, in our opinion, it is necessary to consider the process of commercialization in connection with the functioning of a complex system formation - the innovative infrastructure of the national economy.

The innovation infrastructure in its formed form proves its functionality through the indicator of the level of commercialization of the innovative product. The level of implementation of innovative products by the national economy is assessed through the indicator "The Global Innovation Index" (The Global Innovation Index), which most meaningfully reflects the overall level of innovative development of the economy.

According to the Global Innovation Index 2018 (GII) (Table 4), which determines the ranking of countries for innovation development, the leaders are highly developed countries.

Table 4.Top 10 Leading Countries of the Global Innovation Index 2019

\begin{tabular}{|c|c|c|c|}
\hline $\begin{array}{c}\text { Place in } \\
\text { GII- 2019 }\end{array}$ & Country & $\begin{array}{c}\text { Place in GII- } \\
2018\end{array}$ & $\begin{array}{c}\text { Place in } \\
\text { GII- 2017 }\end{array}$ \\
\hline 1 & Switzerland & 1 & 1 \\
\hline 2 & Sweden & 3 & 2 \\
\hline 3 & United States & 6 & 4 \\
\hline 4 & Netherlands & 2 & 3 \\
\hline 5 & United Kingdom & 4 & 5 \\
\hline 6 & Finland & 7 & 8 \\
\hline 7 & Denmark & 5 & 6 \\
\hline 8 & Singapore & 9 & 9 \\
\hline 9 & Germany & 11 & 17 \\
\hline 10 & Israel & \\
\hline \multicolumn{2}{|c|}{ Source: prepared by the author according to (WIPO, 2019) } \\
\hline
\end{tabular}

As the data show, with a slightly changed ratio during 2018-2019, the list of leaders in the field of innovation in the dynamics of global development remains unchanged. This is because effective innovation creates a kind of innovation multiplier, as growing investment in innovation generates new investment, researchers share their experience and creates a new constellation of highly qualified personnel, and development, innovation and innovation generate new innovation.

In GII-2019, Ukraine took 47th place among 126 countries in the world, entering the ranking by 4 points per year, and bypassing countries such as Chile, Turkey, Georgia, Romania and Moldova. Effective innovation in the country significantly depends on the level of national income, as shown in Table 5.

Table 5. Rating of innovative development of countries in "GII - 2019" by groups selected according to the level of income

\begin{tabular}{|c|c|c|c|c|c|c|}
\hline $\begin{array}{c}\text { Place } \\
\text { in the } \\
\text { group }\end{array}$ & $\begin{array}{c}\text { High-income } \\
\text { countries }\end{array}$ & $\begin{array}{c}\text { Place in } \\
\text { GII }\end{array}$ & $\begin{array}{c}\text { Countries with } \\
\text { above-average } \\
\text { incomes }\end{array}$ & $\begin{array}{c}\text { Place in } \\
\text { GII }\end{array}$ & $\begin{array}{c}\text { Countries with } \\
\text { below average } \\
\text { incomes }\end{array}$ & $\begin{array}{c}\text { Place } \\
\text { in GII }\end{array}$ \\
\hline 1 & Switzerland & 1 & China & 14 & Vietnam & 42 \\
\hline 2 & Sweden & 2 & Malaysia & 35 & Ukraine & 47 \\
\hline 3 & United States & 3 & Bulgaria & 40 & Georgia & 8 \\
\hline
\end{tabular}

Source: prepared by the author according to (WIPO, 2019) 
In the GII-2019 ranking, Ukraine is classified as a group of countries with below-average incomes. The same group included Vietnam (42nd place) and Georgia (48th place).

In GII-2019 there is a positive trend ahead of the indicators of innovative development of 18 countries with economies that are formed relative to other countries with similar income levels. These are countries that show an increased level of innovation compared to their partners, and they include: Moldova, China, India, Uganda, Armenia, Vietnam, Malaysia, Jordan, Mongolia, Mali, Kenya, Senegal, Hungary, Georgia , Montenegro, Costa Rica, Tajikistan and Latvia (the list is given according to the pace of progress) (WIPO, 2019).

Such indicators of innovative development of countries are directly related to an important functional component of the innovation infrastructure of the national economy - the commercialization of innovative products. Under the commercialization of an innovative product means the process of implementation, or bringing to market innovations of various forms and types, generated by a company for profit, or other commercial benefits.

The newly created product takes the form of an innovative product through the process of commercialization and goes through the following stages:

- generating an idea and determining the direction of research;

- conducting research and development work (R\&D);

- creation of an industrial design;

- market research to identify the segment of potential buyers;

- making changes to the innovative product in accordance with the requirements of a certain segment of consumers;

- diffusion of a newly created product - innovations and further implementation of an innovative product.

These stages are not permanent and unchanging, and do not create a closed system, ending with the implementation of an innovative product. The process of bringing to market a newly created product - innovation, ie its commercialization, is associated with high risks, as well as innovation in general. Thus, in the process of conducting R \& D may change the direction of the study, identified in the first stage. The process of diffusion of an innovative product can show the imperfection of the innovation, or - ineffective marketing of the product. And the implementation of an innovative product may be followed by the generation of a new idea and the creation of another, more perfect product. In this case, each stage serves the ultimate goal: at the macro level - to make a profit; at the macro level - to promote the efficiency of the innovation infrastructure of the national economy. Ultimately, the economic effect permeates all levels of the economy, directing its development in the direction of innovation.

The issue of commercializing an innovative product is related to the problem of determining market value. Innovative products are characterized by their uniqueness, which means the impossibility of reducing individual labor costs to public, which are the essence of the "value" of the product. Thus, innovative products do not have "value" as an economic form, however, they are sold in the market, where their price is formed on the basis of a number of marketing factors. This confirms the importance of the marketing component in the process of commercialization of innovative products. The main forms of commercialization are:

- implementation through the involvement of intermediaries - innovation brokers, whose competencies should be legal knowledge on the registration of intellectual property rights, creating a business plan for marketing support, and in general assessment of the commercial potential of the innovative product;

- sale of ownership or use rights through such market forms of cooperation as franchising, franchising, leasing, etc .;

- use of an innovative product by the enterprise-innovator to include the product in the statutory fund.

- sharing an innovative product through the creation of venture capital or business cooperation (as an example - technology alliances). 
The choice of the form of commercialization of an innovative product is determined by the expected commercial benefits from its creation. At the same time, business innovators must have a set of tools to manage the transfer of technology or other innovative products, as technology transfer is the main mechanism for the commercialization of innovation. According to the Law of Ukraine "On State Regulation of Technology Transfer", technology transfer is the transfer of technology, which is formalized by concluding a bilateral or multilateral agreement between individuals or legal entities, which establishes, changes or terminates property rights and obligations regarding technology and its components (Rada. 2006). However, this law is not effective, because it lacks such components of the implementation of its important rules as targeted subsidies for technology transfer and tax benefits for technology transfer.

Modern socio-economic development of national economies is marked by scientific, technical and innovative orientation. At the same time, the role of state regulation of the innovation sphere is growing, and many countries are forming national concepts of sustainable development with the inclusion of innovation goals.

According to the results of academic research on empirical data of the innovation process (KNEU, 2020), there is no functional relationship between investment in research and innovation that appears on the market (Koval, Slobodianiuk, Yankovyi, 2018; Yankovyi et al., 2020; Tsimoshynska et al., 2021). To a greater extent, the innovation is the result of the integration activities of a number of companies and research institutions. Hence the urgent need to develop such levers of public administration that would provide opportunities to unite the efforts of innovation actors - the creation of innovation and technology clusters and links with research institutions, the diffusion of knowledge. This creates the institutional conditions for the formation of the country's basic structural elements of innovation infrastructure of the national economy: technology parks, research centers, business incubators, which together provide effective commercialization of innovations (Arsawan et al., 2020; Arsawan et al., 2021).

The first business incubators were established in the 1960s in countries such as the United States, France and the United Kingdom. Today, such an element of the innovation infrastructure of the national economy is developing in almost all developed countries, along with science and technology parks, creating a favorable innovation environment for business. There are more than 900 business incubators in Europe alone, creating new companies. Developed countries are promoting a strategy of cluster initiatives that combine mechanisms of cooperation and competition. The countries of the European Union (EU), as well as many other countries, have created regional networks of national information points in various areas of technology sectors in order to create conditions for business participation in research. The current trend is the focus of innovation on the creation of environmental innovations, which is generated by the need to preserve the environment, and is determined by the goals of sustainable development of the world's leading countries (Mikhno et al., 2021). Such management decisions contribute to the activation of innovative economic activity of market participants and the effective functioning of the innovation infrastructure of the national economy.

At the same time, there is no comprehensive institutional support for the development of the innovation environment in Ukraine. Elements of innovation infrastructure are not formed, and national business does not receive the necessary support (in the form of financing, consulting, etc.) in the direction of innovation, creation of competitive products and innovation.

The experience of EU countries in the formation of state programs to support innovation is positive. Such government programs are comprehensive and rational; are a kind of open or semi-open platforms for engaging stakeholders in research, business or management; the implementation of programs is carried out on the basis of a predetermined budget, in conditions of time constraints and a clearly defined deadline.

Based on the above analysis, we believe that Ukraine's innovation policy should be based on such important components as - a permanent process of improving the management system of innovation; legislative consolidation of opportunities for integration of national science and business; 
popularization among young people and schoolchildren of the scientific approach to the learning process; development of innovation culture based on the experience of European countries; development of the social environment for the introduction of ecological innovations.

In our opinion, the algorithm for determining the areas of improvement of public administration in the innovation sphere should consist of the following stages:

1. Identification of existing problems of innovation management.

2. Gathering information and processing decisions.

3. Defining mechanisms and tools for implementing management decisions.

4. The process of implementing the chosen strategy.

5. Monitoring and feedback.

6. Based on monitoring and analysis of feedback information, making adjustments and making new management decisions.

Achieving these components by improving the state regulation of innovation in Ukraine will eventually lead to the effective formation and development of innovation infrastructure of the national economy, the ultimate goal of which is the commercialization of innovations.

As foreign experience shows, increasing the level of commercialization of innovative products leads to increased efficiency of the innovation infrastructure of the national economy, as it becomes possible to complete the life cycle of innovation, which in a simplified form consists of logical stages "idea generation-scientific development-industrial design-marketing" . It is at the stage of launching a meaningful transformation of innovation into innovation, as the latter is a commercialized innovation.

In this case, solving the problems of commercialization of innovative products in Ukraine, in our opinion, is to implement the following measures:

- determination of the state priority of creation of conditions for implementation of necessary $\mathrm{R} \& \mathrm{D}$, with active participation of the state in such developments by financial and controlling components;

- improving the structure of public administration in the field of scientific, technical and innovative activities in order to introduce a system of responsibility of public administration;

- development of a state program for the development of national innovation infrastructure with a clear definition of state support instruments aimed at implementing the program;

- improvement of the mechanism of patenting and protection of intellectual property rights;

- development of measures aimed at creating conditions for the organization of production in Ukraine of innovative products 5 - 6 ways (nanotechnology, biotechnology, information and telecommunications technologies);

- creation of a single information base to support innovation - the state system of scientific and technical information, which will contain technical information in all areas of science and technology, patent and license information, data on completed R \& D;

- bringing the system of state statistical monitoring in the field of commercialization of innovative products in line with world standards;

- Improving the education system and conducting basic and applied research by higher education institutions, creating a single mechanism for training highly qualified personnel in the implementation of innovative activities - management, marketing, finance, and commercialization.

Solving these problems, provided they are understood at all levels of government, will ensure high efficiency of commercialization of innovative products as a functional component of construction and development of innovation infrastructure, able to create optimal conditions for the formation of an innovative model of economic growth in Ukraine.

\section{CONCLUSIONS}

The formation of the information society is accompanied by a shift in the priority of economic growth factors from traditional tangible assets - labor, land, capital; to intangible - information, knowledge, creativity, ingenuity. Information and communication technologies are the newest and most powerful tool that facilitates the transition to the post-industrial type of economic development. 
A large mass of assets of companies in the field of infocommunications are intangible assets, the main object of which is intellectual property.

Revolutionary changes in the field of infocommunications create conditions for economic growth and social development of the world economy, as they form a wide range of applied technologies that ensure the functioning of e-commerce, financial markets, global information networks and databases, monitoring various programs and areas, telemedicine, distance learning etc. (Koval, Kremenetskaya, Markov, 2019; Kremenetskaya, Makarenko, Markov, Koval, 2019). Information and communication technologies are becoming a vital stimulus to the development of the world economy, and enable all individuals, firms and business communities to solve economic and social problems more effectively and creatively.

The Okinawa Charter of the Global Information Society identifies information and communication technologies as one of the most important factors influencing the formation of society in the twenty-first century. At the same time, the development and use of ICT in Ukraine is at a level that cannot ensure overcoming information inequality with developed countries and successful integration into the world economic community.

\section{REFERENCES}

Alchian, Armen A. (1965). Some Economics of Property Rights, Il Politico, (30). 816-829

Arsawan, I. W. E., Koval, V., Duginets, G., Kalinin, O., \& Korostova, I. (2021). The impact of green innovation on environmental performance of SMEs in an emerging economy. In E3S Web of Conferences, 255, 01012.

Arsawan, I.W.E., Koval, V., Rajiani, I., Rustiarini, N.W., Supartha, W.G. and Suryantini, N.P.S. (2020). Leveraging knowledge sharing and innovation culture into SMEs sustainable competitive advantage. International Journal of Productivity and Performance Management, Vol. ahead-of-print No. ahead-of-print. https://doi.org/10.1108/IJPPM-04-2020-0192

Basic principles of information society development in Ukraine for 2007-2015 : Law of Ukraine of 09.01.2007 № 537-V. http://www.ukrstat.gov.ua/ [in Ukrainian].

Becker, G.S. (1968). Irrational Behavior and Economic Theory. Journal of Political Economy. 70

Bublyk, M., Koval, V., \& Redkva, O. (2017). Analysis impact of the structural competition preconditions for ensuring economic security of the machine building complex. Marketing and Management of Innovations, (4), 229-240. doi:10.21272/mmi.2017.4-20

Butenko, O.I. \& Lazarov, O. (2008). Infrastructural components of the innovation economy. Economy and forecasting. (4). 69-81 [in Ukrainian].

Drucker, P. F. (1994). Post-capitalist society. New York: Harper Business

Drucker, P.F. (2007). Business and innovation. M .: Williams. 432. [in Russian].

E-Government Survey 2020. https://publicadministration.un.org

Fatkhutdinov, R.A. (2007). Innovative management: textbook for universities. 5 th ed. SPb. : Peter. 488 [in Russian].

Fedulova, L.I. (2017). The knowledge economy in the context of Peter Drucker's views. History of economic thought. (3), 86-99 [in Ukrainian].

Galchinsky, A.S. (2007). Transmarket transformations. Economic theory. (1), 3-12.

Gates, B. (2001). Business with the speed of thought. Moscow: Exmo-Press [in Russian].

Geets, V. More about the warehouses of economic management in Ukraine. Economy of Ukraine. 1998. (11). 17-29 [in Ukrainian].

Global Innovation Index 2019. https://www.wipo.int/edocs/pubdocs/en/wipo_pub_gii_2019.pdf

Hodgson, J. (2001). Socio-economic implications of advances in knowledge and increasing complexity. Economic issues. (8). 32-45 [in Russian].

Hranaturov, V.M. \& Lytovchenko, I.V. (2010). Management of connection services. Kyiv: Education of Ukraine [in Ukrainian]. 
Huriev, S. (2006). Economy myths: Misconceptions and stereotypes propagated by the media and politicians. M., "Alpina Business Books". 260 [in Russian].

IDI 2017 Rank The official site of International Telecommunication Union. ICT Development Index. http://www.itu.int/net4/ITU-D/idi/2017/index.html

IMD World Digital Competitiveness Ranking 2019. https://www.imd.org

Innovation policy: European experience and recommendations for Ukraine. https://kneu.edu.ua/userfiles/our_partners/gudrun/3_UA.pdf [in Ukrainian].

Inozemcev, V. L. (2000). The class of intellectuals in a post-industrial society. Sociological research. (6). 67-77 [in Russian].

Kapelyushnikov, R.I. (1990). The economic theory of property rights: methodology, basic concepts, range of problems. M : IE Academy of Sciences of the USSR. 90 [in Russian].

Koval, V., Kremenetskaya Y., Markov S. (2019). Promising Green Telecommunications Based on Hybrid Network Architecture. 2019 International Conference on Information and Telecommunication Technologies and Radio Electronics (UkrMiCo), Odessa, Ukraine, 2019, pp. 14. https://doi.org//10.1109/UkrMiCo47782.2019.9165525.

Koval, V., Mikhno, I., Trokhymets, O., Kustrich, L., Vdovenko, N. (2020). Modeling the interaction between environment and the economy considering the impact on ecosystem. E3S Web Conferences, 166, 13002. https://doi.org/10.1051/e3sconf/202016613002

Koval, V., Slobodianiuk, O., \& Yankovyi, V. (2018). Production forecasting and evaluation of investments using Allen two-factor production function. Baltic Journal of Economic Studies, 4(1), 219-226. doi:10.30525/2256-0742/2018-4-1-219-226

Kremenetskaya Y., Makarenko A., Markov S., Koval, V. (2019). Limitations of Efficiency of Wireless Systems of Telecommunications 5G and Methods of Their Compensation. 2019 IEEE International Scientific-Practical Conference Problems of Infocommunications. Science and Technology (PIC S\&T). (October 8-11, $2019 \quad$ Kyiv, Ukraine). 493-496. https://doi.org//10.1109/PICST47496.2019.9061493.

Lyashenko, O.M. (2007). Models of commercialization and technology transfer in the global environment. Ternopil National Economic University. Ternopil.

Masp. 279

Mensh, G. (1979). Stalemate Technology: Innovation Overcome the Depression. Cambridge,

Mikhno, I., Koval, V., Korenyuk, P., Smutchak, Z., \& Bozhanova, V. (2021). Modeling corporate games to increase the ecological value of entrepreneurship and innovative business. E3S Web of Conferences, 255, 01027.

Mikhno, I., Koval, V., Shvets, G., Garmatiuk, O., \& Tamošiūnienė, R. (2021). Green Economy in Sustainable Development and Improvement of Resource Efficiency. Central European Business Review, 10(1), 99-113. https://doi.org/10.18267/j.cebr.252

Mykhailovska, O. V. (2009). Ukraine's place in the world process of information society development. Current economic problems. (12(102)). 36-44 [in Ukrainian].

Naumov, A.F. \& Zakharova A.A. (2013). Commercialization of scientific results as a stage of the innovation process. Innovative activity. (2(25)). 46-51 [in Russian].

Nazarova, K., Hordopolov, V., Kopotiienko, T., Miniailo, V., Koval, V., \& Diachenko, Y. (2019). Audit in the state economic security system. Management Theory and Studies for Rural Business and Infrastructure Development, 41(3), 419-430.

Neboha, T.V. (2018). The economy of joint participation as a form of resource sharing. Proceedings of the I International Scientific and Practical Conference "Innovation and modern business technologies in economics and management (union of science and practice)". Sumy State Pedagogical University named after AS Makarenko. (47-50) [in Ukrainian].

NRI 2020 Countries. https://networkreadinessindex.org/nri-2020-countries/

Okynavskaia Khartyia hlobalnoho ynformatsyonnoho obshchestva. Mizhnarodnyi document. https://zakon.rada.gov.ua/laws/show/998_163\#Text [in Ukrainian].

On state regulation of activities in technology transfer: Law of Ukraine of 14.09.2006 №143$\mathrm{V}$ as amended. https://zakon.rada.gov.ua/laws/show/143-16/ed20110301 [in Ukrainian]. 
Pryhoda, V. M. (2000). Development of perspective telecommunication technologies and services in Ukraine in the conditions of globalization. Communication. (3). 2-5 [in Ukrainian].

Pusenkova, I. V. (1997). Study guide "Microeconomics". UNAT, 88 [in Russian].

Pusenkova, Y. V. (2001). Methodology of analysis of the development of relations from economics to intelligence. Odessa: Astroprint [in Russian].

Rachel Botsman \& Roo Rogers. (2010). What's Mine Is Yours: Rise Of Collaborative Consumption. Harper Collins

Schumpeter, J. (1982). Theory of economic development [study of entrepreneurial profits, capital, loans, interest and business cycles]. M.: Progress. 453 [in Russian].

Shmygol N., Galtsova O., Solovyov O., Koval V., Arsawan I. (2020). Analysis of country's competitiveness factors based on inter-state rating comparisons. E3S Web Conferences, 153, 03001. https://doi.org//10.1051/e3sconf/202015303001

Shmygol, N., Schiavone, F., Trokhymets, O., Pawliszczy, D., Koval, V., Zavgorodniy, R., Vorfolomeiev A. (2020). Model for assessing and implementing resource-efficient strategy of industry. CEUR Workshop Proceedings, 2713, 277-294.

Shotik, T.M. (2008). The role of organizations in the development of the national economy. The type of Lviv polytechnics. http://vlp.com.ua [in Ukrainian].

State Statistics Service of Ukraine. www.ukrstat.gov.ua [in Ukrainian].

15

Stigler, G.J. (1961). The Economics of Information. Journal of Political Economy. (69). 213-

The Sharing Economy: Accessibility Based Business Models for Peer-to-Peer Markets. European Commission, "Business Innovation Observatory". https://ec.europa.eu/commission/index_en

Tikhanova, T.E. \& Klescheva, N.G. (2009). An innovative model of economic growth and the ways of its formation in Ukraine. Economics: problems of the theory of practice: Collection of scientific works. (9). 463 - 480 [in Russian].

Tsimoshynska, O., Koval, M., Kryshtal, H., Filipishyna, L., Arsawan, W. E., \& Koval, V. (2021). Investing in road construction infrastructure projects under public-private partnership in the form of concession. Naukovyi Visnyk Natsionalnoho Hirnychoho Universytetu, 2, 184-192. https://doi.org/10.33271/nvngu/2021-2/184

Tykhanova, T. E. (2008). Functions of modern communication in the process of formation of the information society. Scientific works of ONAZ named after O.S. Popova. (1). 97-109.

Where in the world is the fastest internet. https://konkurent.ua/publication/42951/de-u-svitinayshvidshiy-internet/ [in Ukrainian].

World Intellectual Property Organization. http://www.wipo.int/about-ip/

Yankovyi O., Koval V., Trokhymets O., Karpenko M., Matskevich Y. (2020). Economic assessment of investment on the basis of production functions. Turismo: Estudos \&Práticas, 2.

Zavlin, P. N. (2001). How much to spend on science? Innovation. (3). 50-51 [in Russian]. 


\title{
SOCIAL CAPITAL SYSTEM AS A DEVELOPMENT FACTOR AND BEHAVIOURAL ECONOMY CONDITION
}

\author{
Oleksandra Ovchynnykova
}

\author{
${ }^{1}$ Petro Mohyla Black Sea National University, Mykolajiv, Ukraine \\ ORCID ID : 0000-0002-1648-114X
}

\begin{abstract}
Behavioural economics is a symbiosis of psychology, sociology, and economics. It is a branch of science that deeply explores the mechanism of individual choice. Since society is the sum total of individuals who, regardless of their will, cooperate with each other, social capital (as the sum of individuals representing social capital in practice) becomes the fundamental unit of decision-making. Thus, social capital, namely its quality, is a condition for the direction in which the behavioural economy is taking. The paper proposes an approach to the understanding of social capital as a system of interrelated elements that form the concept of social capital. The research also lists the factors influencing social capital and conjectures how the quality of social capital influences the choice of the individual as a representative of social capital.
\end{abstract}

\section{INTRODUCTION}

Behavioural economics is a science at the intersection of psychology, sociology, and principles of housekeeping, multiplied by the historical experience of generations. To explain the behaviour of an object of research, it is important to understand and learn what it is that guides its choices. It does not matter at what level of social relations the individual exercises the right of choice. People are always guided by the principle of minimizing efforts to maximize benefits. Individuals are always selfish. The motives that drive an individual in the decision-making process can make egoism more or less hard. That is why the criterion of rationality and irrationality emerges.

If a person is selfish, so does social capital, as does the totality of individuals who choose to satisfy their own needs. Communication within society cannot be separated from the pursuit of personal goals. It should not be argued that social capital is presented solely as a set of rules and regulations within a social organization. It was erroneous to assume that social capital existed only in the process of public administration and could exist only within the framework of jurisprudence.

Social capital shows all the signs of a system. It behaves like a living organism, creating a symbiotic relationship between the elements of a system. Social capital becomes the basis for the development of a society that demonstrates the quality of social capital. This means that by managing a society, it is possible to control social capital, to shape it, to improve it or to turn it, to make it malleable and unprepared.

The paradox of social capital is that the individual, as part of a system, makes an instant semirational choice (semi-rationality - conditional rationality of choice with no clear signs of rationality or irrationality) at a certain point in time, bringing about changes in society that will manifest themselves in the following genera. Managing social capital is a long-term, strategic project, but management tools must be tactical because the choices made by the individual are always lightning, instantaneous. Despite long-term management, social capital is ductile. In order to find the best tools to influence this category, it is important to analyse the elements of the social capital as a subsystem. 


\section{SOCIAL CAPITAL AS A MULTI-LEVEL SYSTEM}

In considering social capital as an element of a behavioural economy, it is important to answer a number of questions: what is social capital, what generates social capital, what factors potentially affect social capital (quality of social capital), and how this category fits into a behavioural economy, namely how social capital influences the process of choice.

The founder of the concept of «social capital» Pierre Bourdieu (1986) characterized it as social ties, which are a resource for personal gain. Grishnova (2014) proposes to consider social capital as a special form of capital that manifests itself in society and social organizations, in the form of social ties, certain norms and rules, which form the terms of mutual communication of individuals within conditional organizations. It is a quality of mentality that can be studied (evaluated, analysed) at both the micro and macro levels, both for the individual and for society as a whole. Polishchuk (2010) insists that special attention should be paid to social capital, which is inextricably linked by public administration, social sectors, law and public order.

Most of the concepts explain social capital as a homogeneous phenomenon. Why not consider this category, which is studied by sociology, psychology, economics as a kind of basis on which to base relations in society, in the state, in enterprises, in the collective, in the household? Why not to treat social capital as a complex heterogeneous system, which is formed by a number of elements responsible for the quality of social capital? After all, the factors that influence choice, decisionmaking, behaviour are all derived from the activities of the social capital system.

Moreover, it is important to treat social capital and its relationship to behavioural economics as permaculture with which Ethan Roland compares the entire financial system. The idea is based on the principle of an ecological system in which all the components are closely interlinked and where the exclusion of at least one element from the system leads to imbalance and crisis. Just imagine what would happen to society if you excluded, in a time continuum, one generation. It means that the next generation will not be able to learn from their ancestors. It is like a primogeniture.

If the previous generation does not betray the norms of social behaviour, the established rules, the principles of building a society, where will that lead? A new society would naturally emerge, but it would not have the experience of the mistakes of past generations. Such a society is bound to make mistakes that can be avoided. Such generation would have no buffer to smooth the generational conflict. The older ones will certainly criticize the younger generation, and the younger ones will not be able to accept the older position. Each next generation ensures a smooth transformation of society, becoming a buffer between the previous generation and the next. It is the order of generations that are the stepping stones for the development of society - social capital.

So social capital is not enough to be taken as the sum total of human qualities and skills. It is important to understand social capital as a breeding ground on which human capital develops. This category is reflected in knowledge, skills, experience and qualifications. It is the individual is a bearer of human capital. The ability of a person (bearer of social capital) to use his own knowledge and skills is a unique opportunity to apply these skills. From an economic point of view, it is intellectual capital that can create value added through the use of tangible assets and intangible property (patents, licences, brands, trademarks, technologies, etc.).

Social capital directly affects the quality of intangible assets, which are formed by intangible property, human capital, intellectual capital (Fig. 1). It is social capital that creates the potential of a successful, efficient society. In turn, social capital is formed by spiritual, cultural and basic capital. (Fig. 2).

Spiritual capital shows the moral norms and qualities of the individual, which have been instilled in the human being since birth, by generations, by society.

It is a measure of the state of society, it is a peculiarity of culture, it is a mentality, it is an imprint of an era, and it is an indicator of public sentiment. It is what makes an individual understand the forbidden and permitted, the good and the bad, the permitted and the unauthorized. At last, it is a manifestation of human morality. 


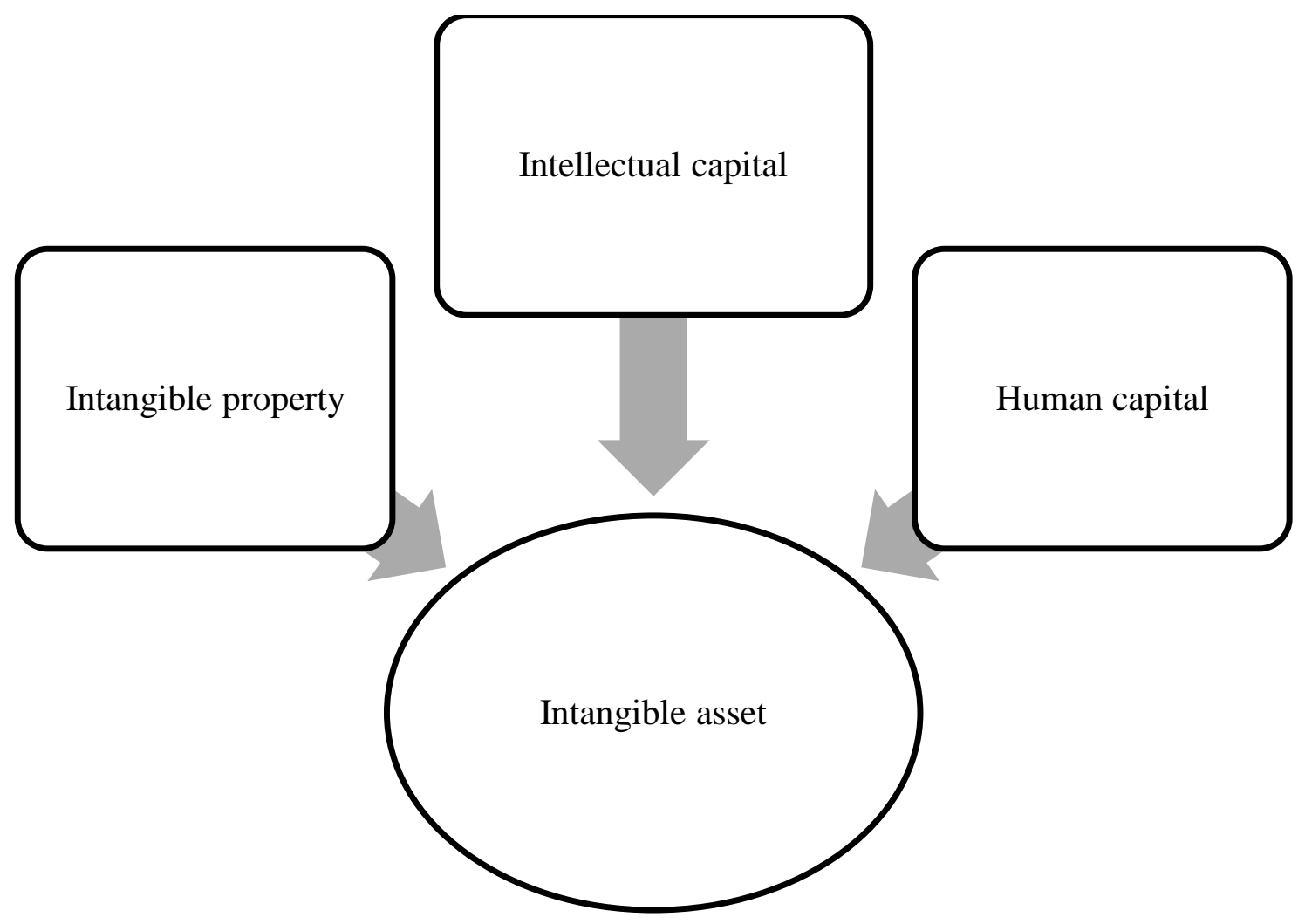

Fig 1. The intangible assets system

Spiritual capital is what teaches us to value preferred alternatives among the available at the level of the subconscious. It forms the principle of choice - rationality or irrationality, conservatism or aggression, making well-considered and considered decisions, or making hyper-risky and lightning decisions.

Cultural capital is supplemented by spiritual capital, manifested in people's ability to organize themselves, to qualitatively do their work whatever it is. Whether it is a mental task or a heavy job, whether it is a service job or a job that the individual has invented for himself. What matters is a man's attitude to what he does. Quality cultural capital is responsible for the ability to work without fear of punishment, without requiring strict control. It is not the case that there are controls that can detect poor quality. It is not a question of punishment as of deprivation. It is a negative assessment of performance, a weighted criticism. The existence of a cultural basis is reflected in the individual's ability to perform his or her functions without external control and supervision, without coercion, and of his or her own free will. It is a manifestation of human integrity in any undertaking. Criticism must be timely and appropriate. An outsider's assessment should not convey the controlling's personal relationship to the controlled. Criticism of quality must be impartial, balanced and adequate. 


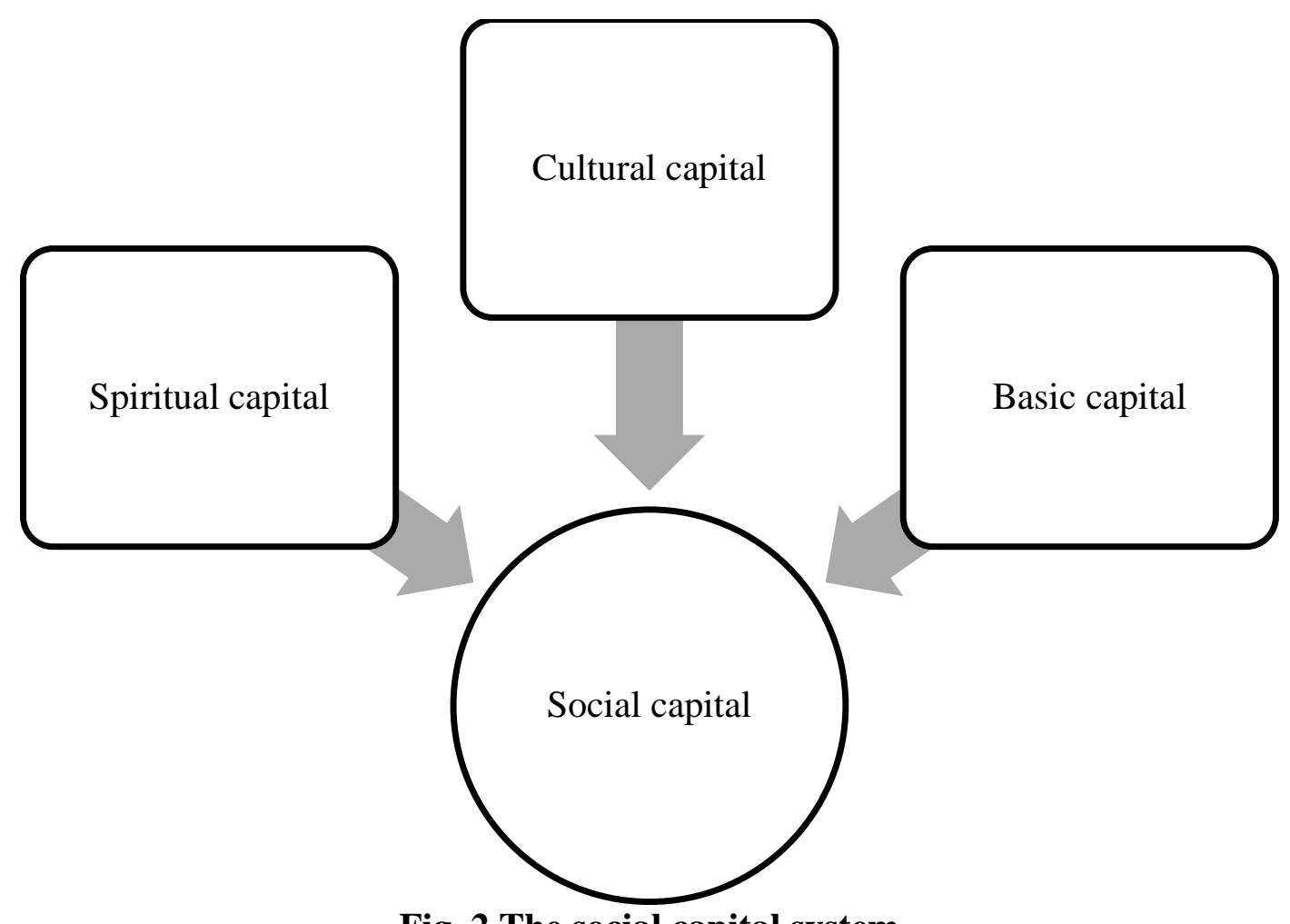

Fig. 2 The social capital system

It is important to note that once a person has reached the highest point of self-organization, sooner or later they will stop seeking to improve themselves for lack of motivation and stimuli. So if social capital is to continue to grow, there must always be motivation. Given the selfish beginnings of each individual, the motivator must be another individual, able to find the weak points of a man who has conditionally reached the top of self-improvement.

At the same time, developed cultural capital minimizes losses. The system does not incur the costs of correcting, finishing, redoing poor-quality work, unreliable products. This is done on condition that the individual values his reputation. Again, a person always chooses to make work easier and to gain the most.

Individuals tend to analyze others' successes, and especially failures, while missing themselves as objects of observation and control. According to Douglas McGregor's motivational theory, purely monetary rewards stop the development of an individual's personality and inhibit potential efforts to improve performance. A combination of tangible and intangible incentives allows maximum self-organization. Behavioral economics affects the choice of individuals as members of society, as employees of enterprises, as citizens of the state.

At the micro level, the presence of highly developed cultural capital in the enterprise leads to the recognition of the company's product. Buyers are beginning to absolutely trust the brand, the trademark. This increases the value of intangible property. This leads to additional profits, new incentives for carriers of human capital (employees who have achieved market recognition of products and thus recognition as highly skilled professionals) in the form of monetary rewards, praise, gratitude and pride for the result of your work.

At the moment when an individual receives a decent material reward for his work (assuming that an employee has chosen a position of high-level self-organization and self-discipline), he is again faced with the choice of how to dispose of his own money. Funds can be spent in material or spiritual values. This is another moment of choice that the individual faces. It turns out that each person is involved in evaluating the alternative on two levels. The first level is mental, the second is material.

Powerful cultural capital shapes the behaviour of economic agents. Choosing between homogeneous goods, the buyer intuitively strives to choose quality and reliability - the Alley paradox (Halasiuk, 2019). This applies not only to purchases, but also to the choice between non-material 
alternatives. In his study, Alley analyzed the trade-off between reliability and the risk posed by the individual. A person who is able to assess risks, seeks stability and reliability, at the level of the subconscious, does not seek radical change. Accordingly, the choice of such a person always seeks security and stability. This position of an agent of behavioural economics can be called conditional rationality. At the same time the choice can be social and market (Ariely, 2020). These two types of behaviour of an economic agent cannot necessarily exist simultaneously. Social and market choices, according to Arieli, can be likened to individual choices at the mental and material levels.

Basic capital is a guarantee that the individual will be able to realize his or her potential as a carrier of human capital. Basic capital is the sum total of all basic human needs, according to Masslow's theory (Tezkan, 2017). In the hierarchical system of motivational theory, physiological needs are at the top, behind them the need to be safe, then the opportunity to occupy a niche in society, to gain self-esteem and self-fulfillment. Providing needs at a basic level is not just about satisfying your «I». It is an opportunity to raise and provide for, raise and culturally enrich their children (descendants, next generation). It is the guarantee of the quality of cultural capital.

In this way, basic capital allows the formation of spiritual capital on the basis of which cultural capital is developed. In close and indivisible interrelationship, basic, spiritual, and cultural capital forms social capital, which in turn is responsible for the quality of human capital, which can combine intellectual capital with intangible property. As a result, intangible assets become a concept that accumulates human capital alongside intellectual capital and intangible property. As a result, a category of intangible assets is created that combines social capital and intangible assets (fig. 3).

Social capital (as part of a system of intangible values) must be seen as a multi-level structure, a dissipative system. In this case, the main criterion for observation, study, and analysis is human capital, which best demonstrates the specificity of the system, accumulating the consequences of changes in the other subsystems. It is a kind of social capital indicator. It is important to note that perceived changes in the quality of human capital are the consequences of long-term changes in elements of the social capital system.

The natural question is how to manage social capital. If social capital directly generates human capital, then social capital is a projection of human capital. In order to assess the quality of social capital, it is important to study and analyze human capital. At the same time, in order to change human capital, adjustments must be made to the formation of social capital subsystems - basic, spiritual, and cultural capital.

The instrument for influencing the basic capital is clearly the satisfaction of the individual's needs. It is important to bear in mind that the only way to realize oneself is in an area of interest. Not one that is considered fashionable or prestigious, monetary or promising. Areas of activity should be characterized by activity rather than status. Only then will the individual choose his or her preferences and be able to perform the task in a high-quality and high-quality manner. Only by eliminating unfair competition in employment will the individual's choice become rational.

Having made rational choice (rational choice according to the individual is quasi-rational), he will get unconditional pleasure from the work performed. This means that they will be able to secure decent housing and food, to feel secure and protected, to have a decent place in society, to be free from self-flagellation and to experience a sense of self-fulfilment. Such an individual would be a rational economic agent (buyer, producer, investor). His choice will be thoughtful and measured, and it will certainly be good. 


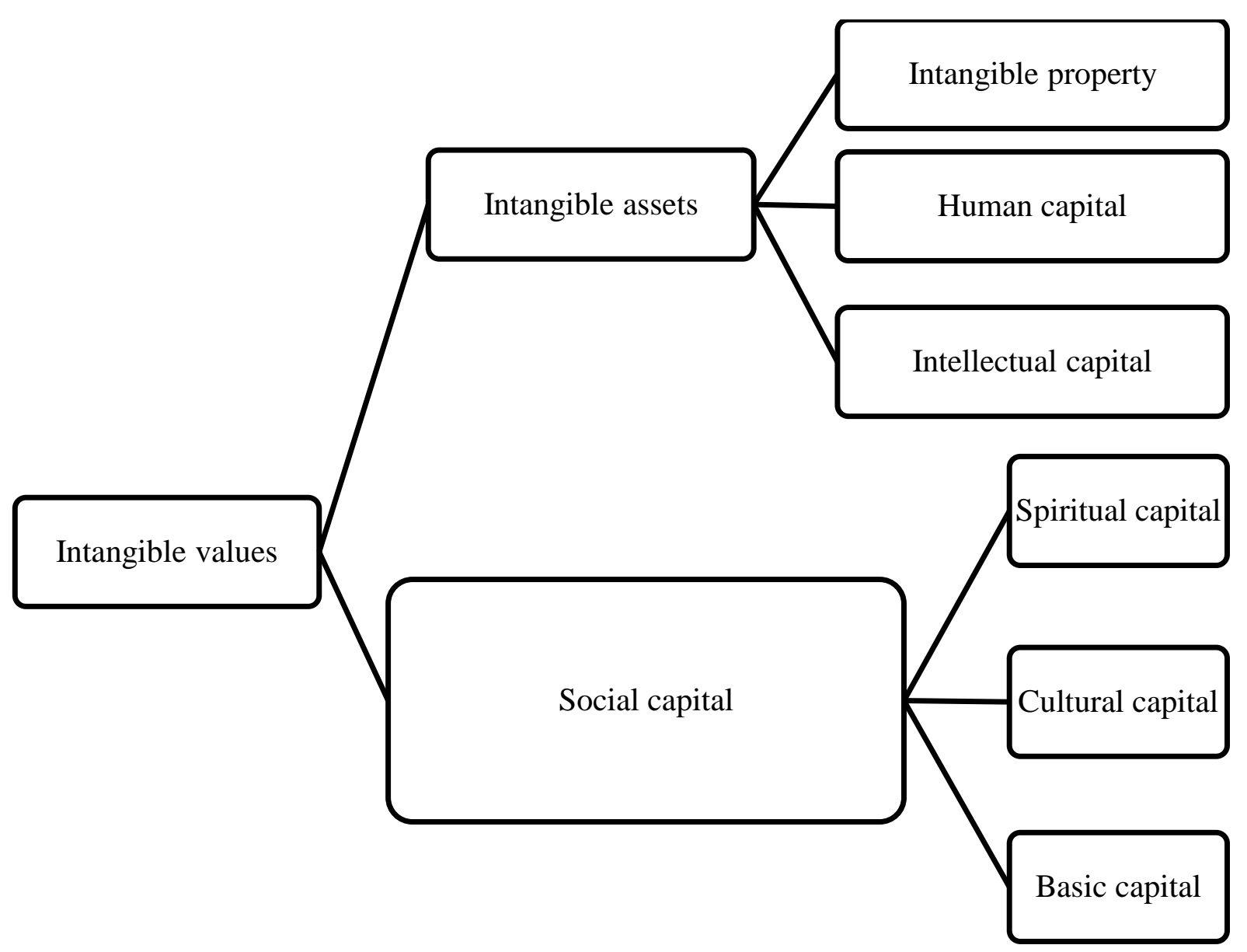

Fig. 3 Material assets category system

With a strong base capital, a rational person will appreciate his position in society, in the community, in the family, will take care of his reputation, he will strive for self-improvement. Of course, the substitution effect will take effect sooner or later (Economics), but it will not affect the quality of the functions performed by the individual. An incentive (instrument) to maximize the quality of cultural capital may be a deliberate criticism, competition between individuals, or a combination of these factors.

Spiritual capital is a chronotop formed by the symbiosis of the basic and cultural capital in the space-time interval. There are no direct positive influences on spiritual capital that make it better and better. At the same time, there are levers that can devalue spiritual capital instantaneously, regardless of the quality of the underlying and cultural capital. There are war, epidemic, catastrophe, individual tragedy, negative force-majeure of different genesis.

Accordingly, the instruments for influencing social capital and human capital as a subsystem of intangible values are:

- level of development and independence of the education system;

- healthy competition and rational criticism;

- force-majeure.

In the short term, it is not possible to change the approach to understanding the education system. An attempt to transform the process of choosing a profession, the process of choosing a job that would give pleasure in a single generation (one generation) is a utopia. Grishnova proposes a tactical approach to this issue. If education is expensive and valuable, it will not be chosen by status, but by vocation. The author of this concept believes that the state should be the primary instrument for the regulation of people's attitudes to the choice of profession and to education. If students receive 
education loans that can be returned as qualified professionals, they will value the knowledge they have acquired. If willing professionals are allowed not to repay the loan but to earn it, people will appreciate their own labour. These are the most intangible instruments for generating the quality of social capital. It would appear that the instrument is directly related to material benefits, but it is the level of self-realization within the basic capital as a subsystem of social capital that is affected.

The use of these influences will affect the quality of social capital in the long run, not to mention force majeure, which destroys all theories and concepts of choice. It is impossible to argue that force majeure forces economic agents to make irrational choices. From the point of view of instantaneous satisfaction of priority needs, the choice is absolutely justified. The alternative created by force majeure most often entails the need to meet basic needs in meeting physiological needs, to create temporary conditions that give the individual a sense of security. In a situation of force majeure, the time allotted for evaluating an alternative is most often aimed at lightning, transforming into intuitive decision-making. But when you compare lightning choice to irrationality, the choice to survive in a moment of time is no longer irrational, it is absolutely rational. Cultygin (2004) argues that in an emergency, trying to gather information to determine the best alternative is nothing but absolute irrationality.

It is rare that a person sees better conditions, is ready to climb the hierarchical ladder of needs and transfers himself from the category of social capital of poor quality to the category of high-quality social capital (hereinafter SC+). In this case, only self-interest becomes the driving force. It is worth noting that $\mathrm{SC}+$ carriers are sometimes limited in their capabilities. Their choice is constrained by budgetary constraints and the choice is therefore relatively rational. For example, there are two SC+ representatives with exactly the same level of social development, but with vastly different financial capabilities. A person with a limited budget will first ensure his or her basic needs. He can not afford more. A person with financial freedom will provide for his or her basic needs and will be able to continue to develop himself or herself as a bearer of cultural capital without hindrance. It is impossible to argue that the behaviour of one individual is rational and that of another is irrational. Their behaviour is completely rational, for their individual circumstances. So, irrationality in this context should be taken as relative or conditional rationality.

The choice depends directly on the society in which the individual lives and develops. The economic and social component of society directly influences the formation of the principles of individual behaviour.

\section{SOCIAL CAPITAL IN A BEHAVIOURAL ECONOMY: WHO MAKES A CHOICE}

If one looks at the system according to Bertalanffy (1969) as a set of interrelated elements that constitute a whole entity and exhibit integrity properties, one can safely argue that social capital influences choices at all levels of the economic system. The previous chapter considered how the individual (household) makes his or her choice and on what his or her choice depends. Now it is necessary to deal with the peculiarities of choice on micro (firm, collective, public organization, etc.) and on macro level (society as such, choice at state level).

At the firm level, the choice must be oriented for the good of the company. Given that the main purpose of a firm's activity is profit, the choice must be directed towards profit. It can be a choice of business policy, choice of investors, choice of personnel. It is any choice at the level of the firm's units.

If the choice belongs to one person (manager, head of department) his choice can be personal. However impartial a specialist may be, he will always (even at the level of the subconscious) be guided by personal interests and sympathies. The situation is similar at the macro level. To overcome the problem of selfishness in choice, it is important to use the voting system. Moreover, voting should be closed, as in the election of heads of state. Open voting forces an individual to look up to others, to try to please, sometimes to do a favour. This peculiarity is particularly evident in the process of selecting the team leader in the enterprise. At the macro level, voting has traditionally been hidden, whereas at the micro level, the most common method is open voting. Again, in open voting, the collective shows signs of collective action (Sysoliatina, 2014). During open choice in the conditions 
of the collective (representatives of society) the choice turns into «weakness of desire». A man knowingly chooses what hurts him, seeing others gain dubious pleasure from such behaviour. According to Elster's concept (1990), collective choice is absolutely entertaining. To overcome the paradox of collective danger, it is important to decentralize choices. This means that if the choice of one relative question is made by a group of individuals, the choice of each individual should not depend on the choice of the other, should not influence the choice of another person and should not have individual consequences for each voter at the personal level (informal).

Open collective choice can become dangerous for society at the level of society if it leads to supposed cooperation or provokes the destruction of relationships within the collective. Alleged cooperation can be understood as corruption. In some cases, cooperation may be of the nature of individual dominance. In such a situation, the team breaks up without benefiting from teamwork. Elster illustrates this paradigm with the example of public transport. In order to avoid congestion in public transport, a person is transferred to a private car. At this point, traffic congestion occurs. Individual dominance leads to the disintegration of the collective, but does not lead to an improvement in the quality of work of both the collective and the individual, and therefore of microlevel organization and society at the macro level.

Besides, it is important to stop paying attention to the word «traditionally». What is traditionally accepted by European countries is categorically unacceptable to countries with different cultural backgrounds. The countries of the East follow traditions and honour the experience of older generations. Such a society is highly disciplined. There is no room for collective choice in such a hierarchical organization. There is only collective obedience. Speaking of the traditional approach, it is again important to divide society into highly developed social capital and traditional society in the classical sense (for example, underdeveloped Third World countries). It can be safely said that the dilemma of choice is based on the personal motives and beliefs of the individual, whatever society the individual is in. What matters is the motives and beliefs of the individual.

This means that choice is always selfish, but the quality and characteristics of social capital determine which forms selfishness takes. Finally, back to what we call rational, which is irrational. In order to assess an individual's behaviour from the standpoint of rationality, it is necessary to examine the basis on which his opinion is based. It is necessary to understand how it perceives the situation, what alternatives it sees and how it evaluates them. It is important to understand that it is not acceptable for an individual to accept what is risky and what is valuable. This proves that the choice is always relative.

What is rational from the point of view of one individual is totally irrational from the point of view of another individual. The relativity test comes into effect. This means that the choice of each is selfish, the choice of each is rational for the subject of choice. In order to balance conflict of interest, it was important to adopt the term conditional rationality.

In parallel with the strategic choice, during the collective choice comes a parametric choice, which obliges the individual to accept the position of each member of the collective and already on the basis of a multitude of opinions, to form his own point of view (his own choice). At this point, the concepts of sub-optimal and counter-weighted are in play. The place where parametric choice prevails is the exchange.

If a situation through an instrument of force compels individuals to come together to make a collective choice, it is important to bear in mind that in one group individuals with different motives cooperate. It has already been mentioned that every human being is absolutely rational relative to his or her own internal world outlook. So, according to Elster, the motives for a man's decision may be as follows:

- Absolute selfishness and rationality to achieve the goal. Such individuals are incapable of cooperation. They tend to dominate.

- An absolute desire for cooperation at all costs. This motif is a derivation of Kant's categorical imperative that individuals come together in a collective where they maximize performance to achieve the best result. This motive changes individual egoism to collective egoism. 
- Utilitarianism in which individuals are willing to cooperate if the level of cooperation is not at extremal points (not at maximum or minimum at the same time).

- Enjoying participation, teamwork and teamwork.

- A conditional obligation to become a participant in the process and a member of the team in order to achieve a goal.

Taking into account such a variety of motives, which are conditionally rational in making a choice for each individual participant, it is important to consciously approach the choice of the leader, the dominant member of the cooperation. Again, it is important to assess the potential outcome of human interaction with different motivations. In this case, it is necessary to predetermine what the real motives of each individual's participation in the cooperation are.

It turns out that it is impossible to achieve mutual understanding and informed consensus through a coercive instrument. Voluntary cooperation, supported by rational consensus, is the key to successful interaction among individuals. So, the personal choice of the individual, the choice of the collective, the choice of the organization and the state, is nothing less than the balance between supply and demand. The equilibrium becomes the point of intersection between benefit (demand) and risk (supply). The point of intersection forms the field of rationality (FR). Everything beyond the field of rationality becomes irrational, forming the field of irrationality (FI) (Fig. 4).

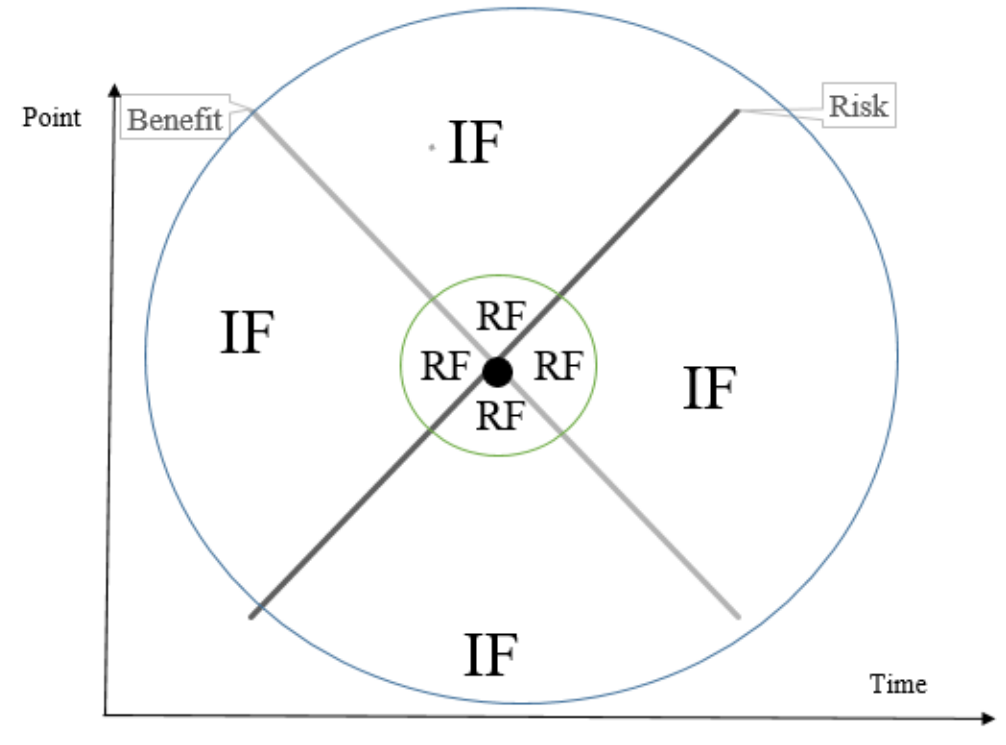

Fig. 4 Benefit and Risk equilibrium

The choice and the risk are evaluated in nominal units and may change over time. The moment, in time, when an individual makes a decision, agreeing to obtain or lose a certain number of units, is the point of decision.

Turning to social capital, its instruments and elements of social capital, one can conclude that the more developed and quality social capital is, the wider the field of rationality becomes.

This means that economic agents are motivated by personal motives, making their own choices, regardless of whose interests they represent or whose public interests they represent. This means that the choice is always selfish, taking into account the personal motives of the individual. That the quality of choice, the impact of choice on society, depends on the quality of the social capital that forms the bearers of human capital.

\section{CONCLUSIONS}

So, social capital is a heterogeneous system formed by a set of elements responsible for the quality of social capital. It is he (social capital, represented by an individual) who makes choices at all levels of the economic system. 
Social capital demonstrates how advanced society is. It is reflected in the carriers of human capital as a projection. Through the prism of social capital it is possible to assess the cultural development of a society, the spiritual component of an individual or a group of people, whether the needs of economic agents are met. The quality of social capital becomes the main parameter of choice that an individual makes as an egoist at the individual, micro and macro levels. It is a measure of the quality of mentality that explains how a person perceives and values an alternative.

The fact of making a choice is described as a balance between a certain number of conditional units of benefit and risk. The point of choice is in the field of rationality. The diameter of the field of rationality depends on how advanced social capital is. The higher the indicator of the quality of the development of this category, the more choices and more alternatives the individual has. Everything we find outside the field of rationality becomes irrational.

As a vector of behavioural economics, social capital remains flexibility. It depends entirely on the cultural, spiritual and basic foundation of the development of society. This affects the behaviour of economic agents, both at the time of individual and collective choice. It is these aspects of social capital formation that need to be taken into account in the attempt to manage behavioural economies by encouraging them to make rational choices.

\section{REFERENCE} Publisher

Ariely, D. (2020). Predictable irrationality, The Social standard prices (p. 86). Moskow: Alpina

Bertalanffy, L. (1969). General System Theory. NY: George Braziller.

Bourdieu, P. (1982). Les rites d'institution." Actes de la recherche en sciences sociales (pp. 58-63).

Cultygin, V. (2004). Rational choice theory - appearance and current state. https://core.ac.uk/reader/229858860

Douglas McGregor, D. (2000). Revisited: managing the human side of the enterprise. Gary Heil, Warren Bennis, and Deborah C Stephens. New York: John Wiley

Elster, J. (1990). The cement of society: a study of social order. Cambridge University Press.

Grishnova, O. (2014). Human, intellectual, and social capital of Ukraine: essence, linkages, evaluation, performance measurement. Retrieved from: https://core.ac.uk/reader/32608909

Halasiuk, V. (2019). Decision-making under the conditions of risk: paradigm shift exclusion paradox Alley. Retrieved from: http://ir.duan.edu.ua/bitstream/123456789/1999/1/5.pdf

McConnel, C. \& Brue, S. (2003). Dictionary of Definitions and Terms. Economics. Principles, problems, and policies $\left(4^{\text {th }}\right.$ Ed.) Moscow: Infra M.

Polishchuk, L. (2010). Civil society economics. Retrieved from: https://www.hse.ru/news/recent/15705861.html

Roland, E. \& Landau, G., (2013). Regenerative enterprise. Retrieved from: http://www.regenterprise.com/regenerative-enterprise/

Sysoliatina, A. (2014). The concept of collective action in the concept of rational Elster's choice. Retrieved from: https://core.ac.uk/reader/229858860

Tezkan, U. (2017). Maslow's hierarchy of needs in $21^{\text {st }}$ century: the examination of vocational differences. Researches on Science and Art in $21^{\text {st }}$ Century Turkey (Ed.): Volume 1, Ch. 23 (pp. 211 227). Gece Kitaplığ1. 


\title{
ECONOMIC AND PSYCHOLOGICAL APPROACHES FOR CUSTOMER TYPOLOGY: CASE OF UKRAINIAN REGIONAL RETAIL MARKET
}

\author{
Oksana Yaskal ${ }^{1}$, Ihor Yaskal $^{2}$, Kristina Volovidnyk ${ }^{3}$, Oksana Loziak ${ }^{4}$ \\ ${ }^{1}$ PhD, Associate Professor, Yuriy Fedkovych Chernivtsi National University, Chernivtsi, Ukraine \\ ${ }^{2}$ PhD, Associate Professor, Yuriy Fedkovych Chernivtsi National University, Chernivtsi, Ukraine \\ ${ }^{3}$ Master Student, National University of Food Technologies, Kyiv, Ukraine \\ ${ }^{4}$ Former Master Student, Yuriy Fedkovych Chernivtsi National University, Chernivtsi, Ukraine
}

ORCID ID (D): "10000-0001-7945-0300, ORCID ID (D): 20000-0002-0339-7168

\begin{abstract}
Background: The research has proved that in the conditions of solving the problems of development in the post-communist countries the problem of finding new approaches to defining the concept and features of consumer behaviour in the changeable environment. Objectives: A significant revision of previously applied approaches to typification of the new types of consumers who have emerged in the new conditions of development of economies and tools to influence their behaviour will be the aim of this paper. Methods/Approach: Methods of analysis and synthesis as well systematization and synthesis of data have been used in the article to improve the typology of consumers while defining modern methods of their influence. The sociological method (in particular, an own interview) has been selected for the rating of consumer choice. Results: It has been proposed a new consumer typology that combines economic and psychographic approaches. The combination of the main neuromarketing tools with the proposed types of customers has been made. Conclusions: The proposed approach will allow evaluating the purchaser at the same time from an economic and psychological point of view to simplify the process of "recognition" of the consumer in order to use appropriate tools to influence his choice and behaviour.
\end{abstract}

\section{INTRODUCTION}

Post-communist past of some countries significantly affects the consumer and his buying motives. In particular, post-communist consumer less psychologically ready for direct contact with the seller and trusts the seller less than consumer from capitalist countries. Therefore, the problem of loss of consumer loyalty in post-communist countries is more acute and needs to be examined for the intrinsic, hidden motives behind consumer purchasing. Also, the rapid development of market relations in Ukraine has led to serious changes in both enterprise management and consumer sentiment analysis. In particular, changing has appeared in the types of customers and the variety of purchasing behaviour by quantitative parameters that force business to deal with the formation of market demand in retail and effective management of customer behaviour. There is an increasing threat of substitutes, limited retail spaces to display a wide array of product assortment in retailers (Deng et al. 2016). Thus, understanding and anticipating changes in customer behaviour takes a forefront (McNeill et al. 2015).

Nowadays, one of the most important components of any economic system is the concept of "economic behaviour", which is defined as the purposeful activity of individuals to satisfy public needs. In modern market conditions for the Ukrainian consumer is presented with a huge number of goods with different properties and the presence of many full substitutes, which make the customer more capricious and demanding. Firms have still explored guided ways to achieve both customer satisfaction and profitability (Keiningham et al. 2014). Businesses should not always expect customers to behave rationally (Elmaghraby et al. 2008) and product and behaviour of consumers are both interesting and advantageous to understand various perceptions due to its inherit nature (Woodward 2009; Reddy-Best et al. 2015).

The company will be able to completely to satisfy their needs, to renew connection and more closely contact with them, to find permanent clients loyal to company`s products by studying the motives and desires of customers. In addition, knowing the factors that influence consumer behaviour in the target market it much easier to improve your position in competition with other enterprises. 
However, such information is rarely available for retail stores. Instead, the retailer needs to categorize customers based on certain characteristics and serve them accordingly (Dodd et al.1998). Customer segmentation has researched customer categorization has a long history going back around 60 years (Van Vliet 2014). While many retailers value this knowledge highly, customer categorization is often based on anecdotal management observations or economic and demographic indicators, rather than real-life retail settings (Reynolds et al. 1999).

According to $\mathrm{Z}$. Bauman, now the main leitmotif of relationships between individuals is not competitive selection, but personalization for all, when for each consumption is a means of selfrealization, the ideal of freedom to choose (Bauman 1998). A satisfied customer influences the enterprise not only through the purchase of goods, but also by forming and disseminating a positive evaluation of enterprise and it's goods. Enterprises that have information regarding of the types of customers, consumer buying behaviour, who knows about the content and nature of the impact of the instruments at this behaviour achieve significant competitive advantages and achieve high results of their activities.

Thus, in postmodern conditions, new patterns of consumer behaviour are emerging that are multidimensional and much more complex. As the consumption process itself becomes more social, the consumer behaviour system is largely determined by the new socio-cultural and institutional environment of consumption. We have had a shortage of empirical research on consumer behaviour in post-communist countries. We have proposed a new approach to consumer typing that combines economic and psychographic approaches based on own empirical research in this article. The working hypothesis has been that the new types of consumers have emerged in the new conditions of development of post-communist economies, which requires a significant revision of previously applied approaches to their typification.

\section{LITERATURE REVIEW}

Scientists are giving lot of attention in economics for studying of customer behavior in a market, process of making decision about purchases and influencing factors.

Philip Kotler and Pfoertsch Waldermar (Kotler et al. 2016), Jean-Jacques Lambin (Lambin 2014), Jack Trout (Trout 2008) and others have identified the factors that influence of consumer behavior, stages of making decision process of purchase the product and levels of consumer behavioral response at the manufacturer`s products marketing actions, identified foundations of the theory features of consumer behavior in retail sales. The above scientists have convinced that three groups of factors are influenced on the customer behavior. The first group is the factors of external influence which ones we can to divide: the motivational by which help the enterprise tries to influence to the process of making decision by purchaser and the unmanaged socio-cultural influence`s factors. The second group of factors is called situational factors, which largely depend on the consumer, his problems, lifestyle, but are not deep psychological or physiological factors. The third group of factors it is the factors of internal influence consist of the psychological and personal characteristics of the consumer. They are the most unexpected factors involved in the purchase decision.

The first taxonomy of consumers by Stone has distinguished between four shopper types based on their orientation toward the shopping activity: the economic consumer, the personalizing consumer, the ethical consumer, and the apathetic consumer (Stone 1954).

More recent typologies have included motivation factors in segmenting customers. Thus, Geuens M., Vantomme D. and Brengman M. have been revealed three airport shopper types: "mood shoppers", "shopping-lovers" and "apathetic shoppers". This type of shopper is indifferent to shopping no matter the context. "Mood shoppers" and "shopping-lovers" are both motivated to purchase due to features of the product. While the mood shopper is mostly triggered by atmospheric and mood elements typical, shopping lovers like shopping in all its aspects, although the infrastructure appears to be an extra stimulation for purchase (Geuens et al. 2004). Williams R., Painter J. and Nicholas H. have determined four consumer types vary on a continuum with regards to their involvement with the level of price or customer service (or both) offered by grocery stores. Interestingly, the study identified a segment of "apathetic' grocery consumers" (Williams et al. 1978). 
As retail store formats have diversified, Ganesh J., Reynolds K.E., and Luckett M. have examined the continued applicability of general shopper typologies and found that different retail formats are patronized by mostly common shopper types (Ganesh et al. 2007).

Recently, researchers have switched focus to develop typologies of multichannel shopping behavior. Konuş U., Verhoef P.C. and Neslin S.A. have identified three multichannel shopper types: "multichannel enthusiasts", "store-focused shoppers" and "uninvolved shoppers" (Konuş et al. 2008). Nilsson E., Gärling T., Marell A. and Nordvall A-C. also have researched the use of Swedish grocery shoppers` for major and top-up shopping trips. They have found heterogeneity of in-format shopping behavior with convenience stores being used by some shopper types for the main shop and supermarkets being used by other shopper types for top-up shopping trips (Nilsson et al. 2015).

Modern theory and Ukrainian practice have many features that can be used to consider different types of consumer behavior. The main of them are presented in the Table 1.

Table 1. Types of consumer behavior with a various characteristic

\begin{tabular}{|c|c|c|}
\hline $\begin{array}{c}\text { Speedy reaction on a } \\
\text { novelty-goods }\end{array}$ & $\begin{array}{l}\text { Roles which performed by the } \\
\text { purchaser }\end{array}$ & Type of consumer \\
\hline $\begin{array}{l}\text { "Adventurer" - the first one } \\
\text { who is trying a novelty, } \\
\text { even with the risk to life, } \\
\text { reputation ( } 2-5 \% \\
\text { consumers). }\end{array}$ & $\begin{array}{l}\text { "Initiator" - interested in the good, } \\
\text { collects attributes of a potential } \\
\text { purchase. Initiates a discussion of a } \\
\text { possible purchase with others. }\end{array}$ & $\begin{array}{l}\text { "Apathetic" - does not give } \\
\text { special preference to goods, } \\
\text { ready to pay competitive } \\
\text { prices, visits stores with a wide } \\
\text { range. }\end{array}$ \\
\hline $\begin{array}{l}\text { "Activist" }- \text { an earlier } \\
\text { follower, leader of thoughts, } \\
\text { makes the good famous and } \\
\text { fashionable } \quad(15-25 \% \\
\text { consumers). }\end{array}$ & $\begin{array}{l}\text { "Influencer" - an individual who } \\
\text { influences the criteria that are taken } \\
\text { into and the range of evaluating } \\
\text { alternatives of goods or brands. }\end{array}$ & $\begin{array}{l}\text { "Rationalist" - demanding } \\
\text { purchaser, wants to see the } \\
\text { highest quality in everything, } \\
\text { prefers convenient location of } \\
\text { outlets, expects to see a wide } \\
\text { range. }\end{array}$ \\
\hline $\begin{array}{l}\text { "Materialist" } \quad-\text { provides } \\
\text { sales at the saturation stage, } \\
\text { late the majority ( } 35-45 \% \\
\text { consumers). }\end{array}$ & $\begin{array}{l}\text { "Solver" - it is the person who makes } \\
\text { the final decision. He has the } \\
\text { financial authority of choice, decides } \\
\text { how the money will be spent and for } \\
\text { what. }\end{array}$ & $\begin{array}{l}\text { "Demonstrator" - purchaser of } \\
\text { high quality goods, requires } \\
\text { fresh and high quality goods, } \\
\text { enjoys the purchase process. }\end{array}$ \\
\hline $\begin{array}{l}\text { "Conservative" - consume } \\
\text { the "novelty" then, when it } \\
\text { becomes "traditional" (12- } \\
18 \% \text { consumers). }\end{array}$ & $\begin{array}{l}\text { "Buyer" - the person who really buys } \\
\text { the good. Acting as a purchasing } \\
\text { agent, purchaser is visiting the store } \\
\text { and checking for the purchase. }\end{array}$ & $\begin{array}{lr}\text { "Meticulous } & \text { purchaser } \\
\text { (aggressor)" } \quad- & \text { giving } \\
\text { preference to } & \text { clean } \\
\text { supermarkets, expects to see a } \\
\text { wide range of goods from } \\
\text { different businesses. }\end{array}$ \\
\hline $\begin{array}{l}\text { "The rigorist" }- \text { do not } \\
\text { accept new goods }(12-18 \% \\
\text { consumers). }\end{array}$ & "User & $\begin{array}{l}\text { "Indifferencer" }- \text { purchaser } \\
\text { who does not care what the } \\
\text { assortment of goods, prefer } \\
\text { convenient location of outlets. }\end{array}$ \\
\hline
\end{tabular}

Source: generalized by authors (Koval et al. 2010; Hasymova 2016; Pysarevskyi et al. 2016).

So, the typification and distribution of customers in the retail market is a different. The above typifications are needed to help sellers more fully have to understand the consumer making decision process for purchasing certain goods, however, in the practice of businesses are researched, analyzed and used extremely limited.

Research about consumer choice for buying things has been done using a lot of Internetresearch and analytical materials. The information has been collected by using search methods and systematized according to the needs of our research.

The conceptual model using the idea of loyalty and value-based models have been proposed by Chatterjee (Chatterjee 2013). Ramanathan U., Subramanian N. and Parrot G. have collected retail 
customers`views in the South East region of the UK on weekly grocery shopping experiences with respect to various features such as loyalty schemes, convenience and price. The results of the analysis clearly specify the moderating role of different promotions in the relationship between service operations and customer satisfaction (Ramanathan et al. 2017). Ramanathan U., Subramanian N., Yu W. and Vijaygopal R. have used survey data from prominent U.K. retail store customers and shown that both loyalty and service operation attributes have positive significant impact on customer behavior, while the service operation mediates the relationship between loyalty and customer behavior. This result has given a new outlook to build managerial capability based on customer loyalty and service operations (Ramanathan et al. 2017).

While the results of the research Harris P.W., Riley F.D., Riley D., and Hand C. have provided profiling grocery shoppers on the basis of their concomitant perceptions of shopping online and in store. Authors have suggested that the choice of whether to shop online or in store may be driven not by the perceived advantages of one channel versus the other, but by the desire to avoid the greater disadvantages of the alternative. These perceptions differ somewhat between different consumer groups (Harris et al. 2017).

Different customer behavior that has previously not been known by the retailer Andreas L. and Børge S. have studied. They have demonstrated the viability of using RFID to categorize customers into a number of behavioral traits in the fitting room. RFID data is used to elicit a few broad types of customer behavior. The typology is based upon fitting room episodes with multiple products, where POS data comparison is used to validate the outcome of each episode; i.e., what the customer ends up buying (Andreas et al. 2017). On the other hand, the study of Paulssen M., Brunneder J. and Sommerfeld A. have tested the differential impact of the two main customer relationship predictor paths - identity-based and satisfaction-based paths - on customer in-role and extra-role behaviors. The identity-based path impacts purchase behavior only when symbolic purchase motivation is high. Overall satisfaction has no impact on purchase behavior (Paulssen et al. 2019).

Poll, which was carried out by Shopper Trends in 2015 among the economically active residents of Ukraine have shown that despite often shopping (43\% of Ukrainians do shopping more than 5 times in a week) in general they keep saving: $30 \%$ have started even more savings on food; $85 \%$ make up a shopping plan; $70 \%$ told they clearly follow to this plan. Young people (18-24 years old) and retirees (55-64 years old) spend the least. In most times, the families make a decision about purchases together, according to $52.6 \%$ of those respondents, according to Business.ua. The practice has shown that the decisions that are most likely to be dominated by a man include the purchase of sophisticated technical instruments, tools to support technical systems. Decisions about buying food, household items, furniture, and children's clothing are most likely dominated by women. To the common decision often include leisure, vacation, buying a fridge and a TV. To the own decisions include the purchase of jewelry, books and newspapers of individual interest (Nahorskyi 2017).

In the conclusion, modern science and practice that is learning consumer behavior got far enough but still, it cannot give us the final answers that will be able to explain us all possible options of consumer behavior. We have a lot of different research but not enough about consumer motivation and learning about consumer type in Ukraine. After all, in order for a customer to buy a particular good again, it is necessary to react in time to their behavioral reaction. That is why, at the present stage of development of the Ukrainian economy the theoretical and applied study of consumer behavior is important, in order to provide effective means of regulating consumer behavior in the retail market. There are numerous challenges associated with consumer typologies in retailing. For instance, large diversity across factors, static segments and different approaches. The problem is that identified typologies do not remain unchanged over time in terms of size and profile. We have suggested that typologies have to adapt to the situation, which puts less reliance on traditional methods. 


\section{METHODS}

The information base of the research has been legislative and regulatory documents, scientific works, materials of periodicals, and also questionnaire`s information (the method of a questionnaire conducted among consumers was used to collect the necessary information), which was personally elaborated by the authors.

The methodological basis of the study of consumer behaviour in this article has been systematic and complex approaches in determining the economic content of the concept of "consumer behaviour", its structure and factors of influence, consumer typology, features of modelling consumer behaviour; methods of analysis and synthesis; systematization and synthesis of data to improve the typology of consumers while defining modern methods of influence on the consumer. During research with a goal to the rating of consumer choice have selected method of collecting information which has high accuracy and practical significance in the studying consumer behaviour specifically a sociological method (in particular, an interview).

An empirical study has been conducted by the authors of the article. Our own sociological research has conducted on the basis of questionnaires at the outlets of one of the largest retail market networks of Ukraine: Auchan Ukraine, Epicenter, METRO Cash \& Carry Ukraine in Chernivtsi region (Ukraine). These outlets have been selected because of their popularity. Simple random of sampling has used to identify the study objects. Participants in this research were individuals aged 25 to 65 (457 people), most of them women, mostly middle-income. The detailed sample structure has presented in Appendix 2. The study was conducted during February-April 2019. The sampling error has $1.2 \%$. Factual names of the participants are not mentioned in any section of this study.

There has been used in-depth and structured interviews for data collection since it is the most appropriate method considering the goal of the study. In accordance with E. Golubkov`s research quantitative methods were used, a tool for gathering primary information was structured for consumers and observation (System analysis, n.d.). Also, the choice of interview questions has influenced by a number of previous researches instruments in developing the interview questions to ensure validity (Saunders 2011; Leung 2015). The exact wording of the questions has been presented in Appendix 1. The questionnaire has been divided into two blocks and designed to determine what factors influence a consumer to choose, purchasing a good and what type of consumer it is. Respondents could choose a maximum of two answers. The analysis of each questionnaire has done individually and, based on the answers, a conclusion has made.

\section{CONDUCTING RESEARCH AND RESULTS}

Evaluation of consumer choice depending on its type

Research of consumers, their consumer behavior is a difficult process that involves evaluating the goods and services they receive, their actions and intentions related to choosing the most attractive goods or services, and making consumer-purchasing decisions. But we pay attention to the consumer`s assessment of the types and factors that influence the choice of purchase (Appendix 1). The results of the questionnaire have conducted by the authors in the Chernivtsi region (Ukraine) covered 457 people. Sample structure: males: 178 persons, females: 279 persons; by age: $18-25$ years - 73 people, 26-34 years - 105 people, $35-45$ years - 100 people, $46-55$ years -92 people, older 56 years - 87 people; by income level: with average income - 321 people, high-income - 54 people, low-income -82 people (Appendix 2). The results of the first block of questionnaires are presented in the Table 2. 
Table 2. The most influential factors for the consumer`s choice of Chernivtsi region (Ukraine)

\begin{tabular}{|c|c|c|c|c|c|c|c|}
\hline Indicators & Quality & Price & Brand & Service & $\begin{array}{l}\text { Appe- } \\
\text { arance }\end{array}$ & $\begin{array}{c}\text { Adver- } \\
\text { tising }\end{array}$ & $\begin{array}{l}\text { Other } \\
\text { factors }\end{array}$ \\
\hline Semi-finished goods & 385 & 395 & 20 & & 15 & 11 & 16 \\
\hline Sweets & 391 & 361 & 14 & 19 & 29 & & \\
\hline $\begin{array}{l}\text { Alcoholic beverages and } \\
\text { tobacco }\end{array}$ & 173 & 184 & 287 & & & 37 & \\
\hline Fruits, vegetables & 154 & 243 & & & 348 & & \\
\hline Meat goods & 411 & 388 & & & 18 & 21 & \\
\hline Dairy goods & 387 & 379 & 48 & & & 18 & 10 \\
\hline Bread & 365 & 408 & 26 & & 21 & & \\
\hline Household goods & 256 & 301 & 31 & 38 & 42 & 14 & 35 \\
\hline Clothes and shoes & 143 & 167 & 301 & & & 329 & \\
\hline Household appliances & 372 & 142 & & 322 & & & \\
\hline Hygiene goods & 172 & 212 & & & & & 252 \\
\hline Medical goods & 178 & 201 & & & & & 231 \\
\hline Furniture & 232 & 55 & 149 & 362 & 210 & & \\
\hline
\end{tabular}

Source: generalized by authors based on own questionnaire.

According to the results of our research main role in choosing a purchase play two factors: price and quality. Therefore, there are consider their interdependence and the level of influence graphically (Fig. 1).

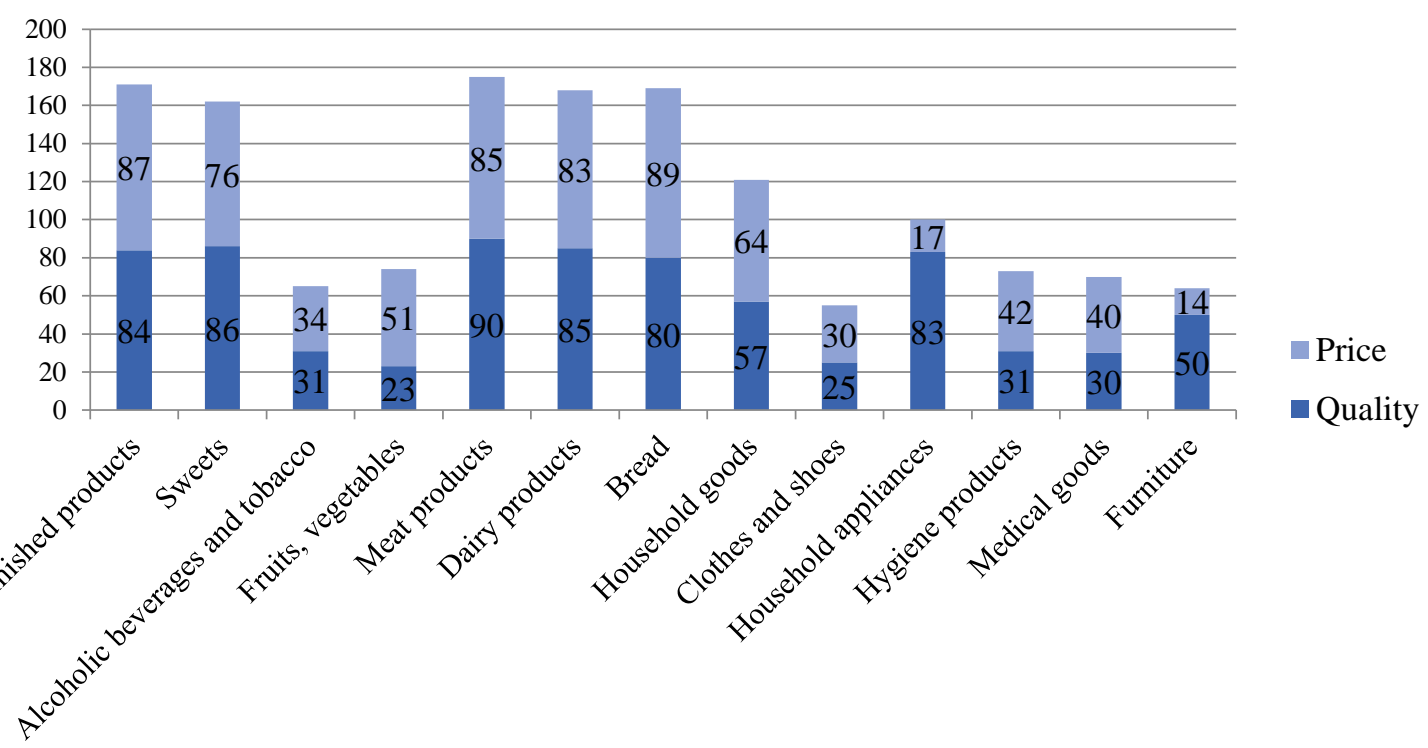

\section{Figure 1. The level of influence of price and quality on the choice of consumer's purchase in Chernivtsi region (Ukraine) \\ Source: own calculated.}

The results of the questionnaire, conducted by authors of Chernivtsi region (Ukraine), have pointed out that the price is not a key factor in the case of purchasing more expensive goods of durable using. In addition, quality, warranty period ( $72-83 \%$ of respondents) is a significant factor in the case of buying furniture, cars, appliances; safety and reliability (56\% of respondents) - in purchasing medical goods, hygiene goods and cosmetics. The purchaser is influenced by brand and advertising (70-75\% of respondents) in choosing clothes and shoes. The consumer prefers quality goods and pays attention to the price (84-90\% of respondents) in buying provision. In most cases, the choice is influenced by the brand and again the price (60\% of respondents) in buying alcohol and tobacco. Vegetables and fruits are bought based on appearance (77\% of respondents). There has been an attempt to segment the consumer market Chernivtsi region (Ukraine) on a psychographic basis based on the answers of the second block of survey questions (Table 3). 
Table 3. Characteristics that describe the behavior in the store (in the mall, in the market) of consumers of Chernivtsi region (Ukraine)

\begin{tabular}{|l|c|}
\hline \multicolumn{1}{|c|}{ Content of statement } & $\begin{array}{c}\text { Number of } \\
\text { respondents, } \\
\text { persons }\end{array}$ \\
\hline $\begin{array}{l}\text { If I see that everyone is buying this good, then I also will not refuse such a } \\
\text { purchase }\end{array}$ & 14 \\
\hline I quickly choose the required good & 96 \\
\hline I always weigh all the pros and cons before purchasing a good & 160 \\
\hline I look through the whole range of good group and then choose & 123 \\
\hline Before making a purchase, I make a list and follow it clearly & 174 \\
\hline $\begin{array}{l}\text { Often use the seller`s recommendations and consultant services and we } \\
\text { choose together the good }\end{array}$ & 55 \\
\hline Without all the good information, I don`t buy the good & 73 \\
\hline $\begin{array}{l}\text { I use all the discounts all the time also take part in promotions and sales and } \\
\text { buy such a good even if I do not need it at all }\end{array}$ & 50 \\
\hline $\begin{array}{l}\text { I often change locations because it is difficult for me to choose a really high- } \\
\text { quality good }\end{array}$ & 48 \\
\hline I go shopping often, but I usually buy almost nothing & 82 \\
\hline I like to always try something new, I am not afraid of change. & 64 \\
\hline
\end{tabular}

Source: based on own questionnaire.

A typology of consumers has been developed based on the second block of questions of the questionnaire which it has possible to distinguished the following types:

1. Innovators. Consumers prefer the new good. Such consumers are looking for the required thing for a long time. They use the good for a short time and consider it and themselves fashionable, modern. Survey result: $14 \%$.

2. Rationalists. Persons make the right choice by not with help advertise. They always know what they want and choose the good for a long time. Survey result: $38 \%$.

3. Individualists. They need to know all the information about the good. It is difficult for them to choose a good. Therefore, they often use the services of consultants. Survey result: $16 \%$.

4. Apathetics. Consumers quickly select the good. They are not long delayed at the store. Mainly, these persons are of low income. Survey result: $21 \%$.

5. Activists. People make impulse purchases. They like stock and sales and visit a large number of commercial establishments. Survey result: $11 \%$ (Fig. 2).

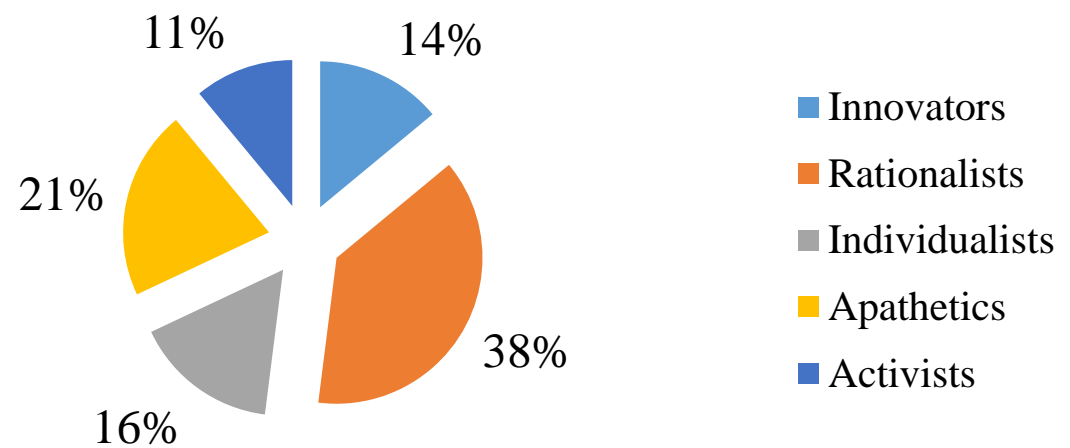

Figure 2. Structures of consumer`s behavior of Chernivtsi region (Ukraine) based on their psychographic type

Source: based on own questionnaire. 
As the results of our study testify, the rationalists dominate in the retail market of Chernivtsi region (Ukraine). However, the difference between all structural units of psychographic type is not significant. It can be concluded that there is a certain balance between all types of consumers. Enterprises can evaluate and form consumer opinions, depending on what purchaser rely on evaluating a good. In general, we can conclude on increasing in the segment of consumers who choose a brand new form for the retail market - supermarkets after a thorough analysis of consumer motivation to make purchases in retail chains.

Improving the typology of customers based on economic and psychographic approaches

Having information about the customer's behavior and the stages in which they decide to buy the good does not fully solve the issue of effective sales management. For this purpose, various tools of influence on the purchasing power should be applied. They are a set of levers with which to guide customers towards the exercise of the purchase of goods.

The seller should be able to find an individual approach to any type of customer in order for the purchase decision to be successful. Therefore, salespeople need to determine what kind of person the customer is and then address to him in his "own language".

We have attempted to combine and compare the classic typology of consumers which is described in the literature review with their non-traditional types. This attempt has evaluated the customers from the economic and psychological point of view, which will simplify the "recognition" of the purchaser and use the necessary tools to influence him.

Tools impact the consumer should be used depending on its type:

1. For the innovator-boaster. The most effective tool to influence the behavior of such consumers is using advertising. It is a way of commercial promoting a positive image of the business. The most powerful of these is viral advertising among the various types of advertising in influencing customer behavior. Viral advertising is information about goods, businesses, their staff received from colleagues or friends. No other advertisement can compete with viral advertising in its importance, influence. It will be good to use a trademark as a tool. Trademark helps to improve marketing activities, increases the value of goods in the eyes of consumers, activates their buying behavior. The presence of branded goods helps purchasers to make consumer choices.

2. For rationalist-expert. The best practice will be to apply the optimum pricing policy and offer only quality goods for this type of consumer. The consumer should be aware of the reasonableness of the cost of each penny. If the seller does not explain the origin of the increased price of one of his brands, in particular, does not associate the increased price with the higher quality, then the good will lose some of its purchasers. Ensuring the adequacy of price and quality allows keeping a record of the graduation of goods and services by quality (varieties, brands, classes, etc.) (Fig. 3). 


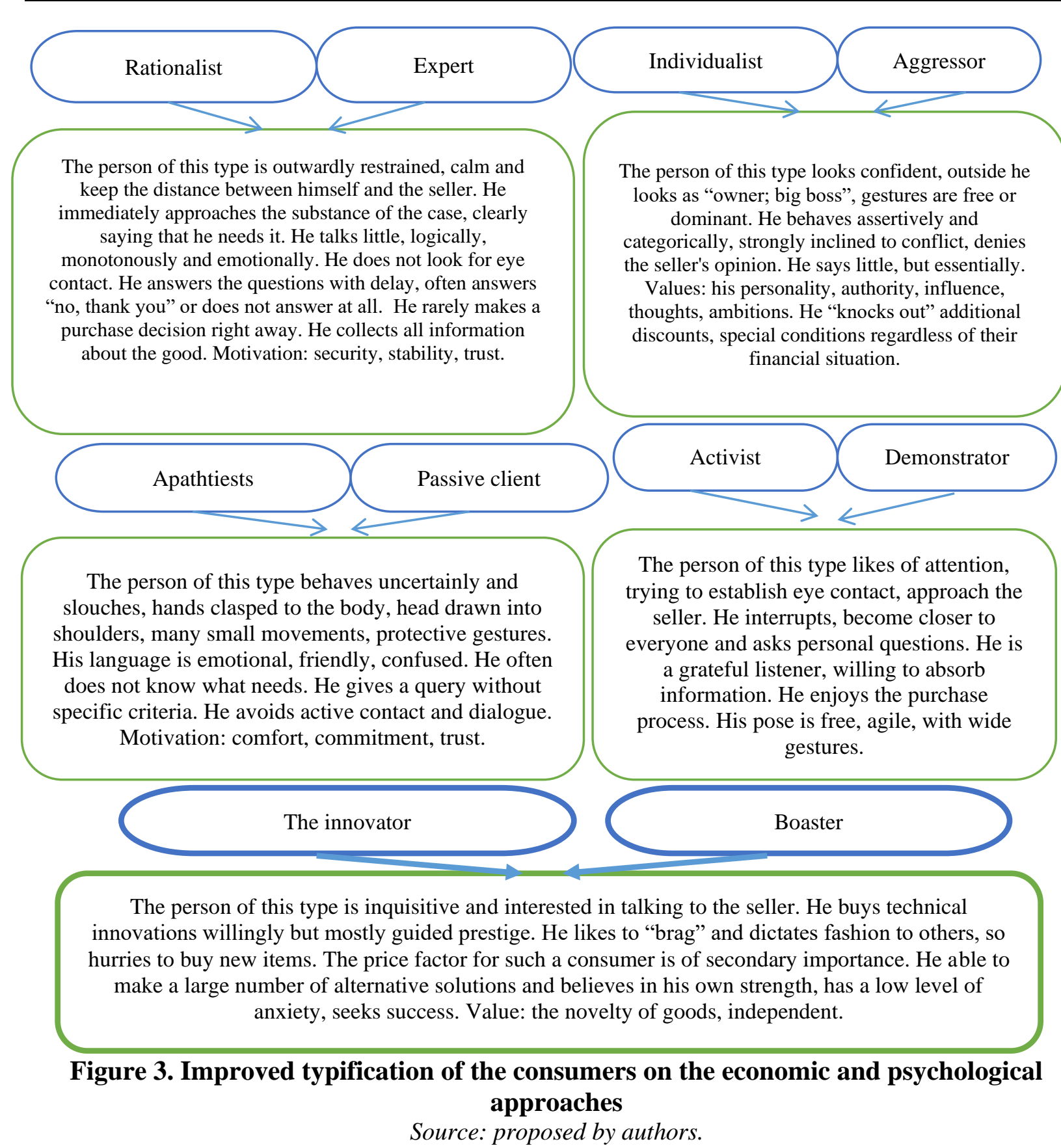

3. For individualist-aggressor. Individuals strive to choose the required good for them, therefore, they need proper service. Experience has shown that a salesperson offers customer service achieves significantly better sales. The volume and quality of service should be quite noticeable for the consumer. Luxury, expensive goods require more service, and it should be convenient and fast.

4. For apathetics-passive clients. The use of direct marketing, including direct mail, telemarketing, outbound retail, computerized retail, other types (fillers, inserts, flyer layout, sales through the seller) is most appropriate for this type. It is also advisable to stimulate sales at places of commerce - posters, wobbler, signboards and etc.

5. For activist-demonstrator. These consumers should be maintained using a regular system of discounts and promotions, free samples of goods, coupons-certificates, prizes (contests, lotteries, games), cash or other types of remuneration. Merchandising also has a great role as a tool to influence the behavior of customers` activists (flyers, posters, show card, indicator board, punnet for upselling, relief figures, hologram displays, items on display, positioning of a store shelf, field and storefront testing etc.) 
Retail business can achieve success only with professional sellers who can quickly determine the type of consumer and respond to their reaction in time, use appropriate tools of influence.

Therefore, retail business needs to use a wide range of tools, namely those that are easily customizable and adaptable to any consumer environment and aimed at ensuring strong customerbusiness relationships in order to increase sales. The proposed consumer typification will help identify them and quickly change the instruments of influence in order to focus on the highest priority for this type of purchaser.

\section{Innovative techniques for influencing consumer choice}

There are also non-traditional methods using innovative technologies along with traditional methods of influencing the ultimate customer today. These methods are designed to better meet the needs of consumers, taking into account their preferences, requirements and reactions.

One of the new areas of study of consumer behavior at the psychological and economic level is neuromarketing. According to research "neuromarketing" loosely refers to the measurement of physiological and neural signals to gain insight into customers' motivations, preferences, and decisions, which can help inform creative advertising, product development, pricing, and other marketing areas. Brain scanning, which measures neural activity, and physiological tracking, which measures eye movement and other proxies for that activity, are the most common methods of measurement (Harrell 2019).

Neuromarketing should be seen as a process of exploring consumer behavior (emotions, thinking, cognition). Psycho-emotional methods of influencing consumers include sound, visual, taste, tactile and aromatic. An attempt was made to combine neuromarketing tools depending on the type of customer by the authors.

In our opinion, the most common methods for the individualist-aggressor are visual. Light effects highlight the good and attract attention to it, helping the consumer navigate the hall. Lighting, as well as color, provides visual and aesthetic comfort for the purchaser. Sound subconsciously influences on making a decision and human behavior. It is the most suitable for a demonstratoractivist, for creating a comfortable atmosphere. Aromarketing can have the greatest impact on the apathetics-passive clients and is based on the using of a variety of odors and aromas to stimulate sales, promote goods on the market and have a positive impact on the consumer.

We consider promotions and tastings to be one of the most effective ways of promoting goods for the innovator-boaster. There is also the concept of sampling - the essence of which is to distribute goods to consumers by free. To make contact with a potential consumer closer and more spectacular, you can use interactive equipment (projection (virtual) and video showcases, virtual counters, virtual show-rooms, QR codes etc.). In addition, POS materials are used to help the consumer navigate directly to the point of sale in a timely manner and therefore increase the likelihood of purchases (Table 4).

Summing up, it is appropriate to emphasize that retail business should use new ideas and technologies into goods, services and processes in the conditions global market and maintenance positions. 
Table 4. Application of neuromarketing methods depending on the type of customer

\begin{tabular}{|c|c|c|c|}
\hline Method & Instruments & Characteristics & $\begin{array}{l}\text { Type of the } \\
\text { consumer* }\end{array}$ \\
\hline \multirow{4}{*}{ Sound } & $\begin{array}{l}\text { The structure of the } \\
\text { message }\end{array}$ & $\begin{array}{l}\text { "what", "when" and "how" as necessary } \\
\text { elements of the message which make it more } \\
\text { acceptable }\end{array}$ & \multirow{4}{*}{$\begin{array}{l}\text { Activist- } \\
\text { demonstrator }\end{array}$} \\
\hline & $\begin{array}{c}\text { Musical } \\
\text { accompaniment }\end{array}$ & $\begin{array}{l}\text { the tempo of the music depending on the } \\
\text { situation and point of sale }\end{array}$ & \\
\hline & $\begin{array}{l}\text { Sound design or } \\
\text { audio marketing }\end{array}$ & forming sound and modifying its categories & \\
\hline & Audio message & $\begin{array}{l}\text { duration of sound and repetition, time of day } \\
\text { for sound }\end{array}$ & \\
\hline \multirow[b]{2}{*}{ Tactile } & Good material & the material of the good and packaging & \multirow{2}{*}{$\begin{array}{l}\text { Rationalist- } \\
\text { expert }\end{array}$} \\
\hline & $\begin{array}{c}\text { Material of } \\
\text { additional items }\end{array}$ & $\begin{array}{l}\text { material of additional objects (furniture, } \\
\text { tableware, etc.) }\end{array}$ & \\
\hline \multirow{2}{*}{ Taste } & Taste additives & $\begin{array}{l}\text { food additives (cause "attachment" to taste and } \\
\text { good) }\end{array}$ & \multirow{2}{*}{$\begin{array}{c}\text { The } \\
\text { innovator- } \\
\text { boaster }\end{array}$} \\
\hline & Taste test & $\begin{array}{l}\text { sample of goods to potential consumers to get } \\
\text { acquainted with their taste properties }\end{array}$ & \\
\hline \multirow{3}{*}{ Aromatic } & \multirow{3}{*}{ Aromarketing } & aromatization of buildings of points of sale & \multirow{3}{*}{$\begin{array}{l}\text { Apathtiests- } \\
\text { passive } \\
\text { clients }\end{array}$} \\
\hline & & aromatization of goods & \\
\hline & & $\begin{array}{l}\begin{array}{l}\text { aromatization of catalogues, trial goods, } \\
\text { souvenirs }\end{array} \\
\end{array}$ & \\
\hline \multirow{4}{*}{ Visual } & Point of sale & merchandising, design of points of sale & \multirow{4}{*}{$\begin{array}{l}\text { Individualist- } \\
\text { aggressor }\end{array}$} \\
\hline & Color scheme & color selection depending on symbolism & \\
\hline & $\begin{array}{l}\text { Good form and } \\
\text { packaging }\end{array}$ & $\begin{array}{l}\text { form of goods and their packaging (oval, } \\
\text { square, non-standard figure, etc.) }\end{array}$ & \\
\hline & Video ads & $\begin{array}{l}\text { duration and repetition, use of video } \\
\text { advertising tools (joke, character creation, } \\
\text { atmosphere, etc.) }\end{array}$ & \\
\hline
\end{tabular}

Source: based on (Solomon, 2018).

As a result, each customer gets the required goods, becomes more satisfied, the society solves current problems at the expense of a community of satisfied consumers, and the retail business increases sales, profits and long-term prospects in the retail market.

\section{CONCLUSIONS}

This research has aimed to examine consumer buying behavior in the retail sector, develop consumer choice analysis, and evaluate purchaser impact tools. The analysis of the scientific literature has demonstrated that understanding and managing the consumer`s needs and the processes of their decision to buy the goods are the keys to the success of the business activity of enterprises. The most important groups of factors influencing the purchasing behavior of the consumer were identified such as psychological, personal, economic. The essence of consumer choice can be understood through three basic patterns of consumer behaviour: traditional, economic and behavioural, modern. Also, the basic applied research has been examined that has been used to conduct customer segmentation on the retail market.

A sociological survey has done in the outlets of Chernivtsi region (Ukraine): Auchan Ukraine, Epicenter, METRO Cash \& Carry Ukraine, which demonstrated that $38 \%$ of respondents are rationalists, $21 \%$ - apathtiests, $16 \%$ - individualists, $14 \%$-innovators, $11 \%$ - activists. Respondents have indicated that the main criteria for choosing a particular good were price, quality, brand and advertising, service and appearance of the item.

Our customer typology is based on a combination of economic and psychological approaches, which is the scientific novelty of the work. This makes retail businesses to adapt quickly to consumer demands, identify the psychological type of consumer (through verbal and non-verbal 
communication), which will allow to react the consumer's response and use appropriate tools of influence in time. Also, the main neuromarketing tools have combined with the types of consumers and showed that it makes sense the feasibility of using them.

The main points that retail businesses should focus their attention on are: targeting consumers, developing an optimal pricing policy, providing only high-quality goods, distributing appropriate advertising tools and branding, providing professional service, using effective merchandising and the latest technologies.

\section{REFERENCES}

Andreas, L. D., \& Børge, S. (2017) Tracking customer behaviour in fashion retail using RFID. International Journal of Retail \& Distribution Management, 45 (7/8), pp. 844-858, DOI: https://doi.org/10.1108/IJRDM-10-2016-0174.

Bauman, Z. (1998). Globalization: The Human Consequences. Columbia University Press.

Chatterjee, S. (2013). Simple rules for designing business models. California Management Review, 55 (2), pp. 97-124. DOI: https://doi.org/10.1525/cmr.2013.55.2.97.

Deng, X., Kahn, B.E., Unnava, H.R., \& Lee, H. (2016). A “wide" variety: Effects of horizontal versus vertical display on assortment processing, perceived variety, and choice. Journal of Marketing Research, 53(5), pp. 682-698. DOI: https://doi.org/10.1509/jmr.13.0151.

Dodd, C. A., Clarke, I. \& Kirkup, M. H. (1998). Camera observations of customer behaviour in fashion retailing: methodological propositions. International Journal of Retail \& Distribution Management, 26, 311-317.

Elmaghraby, W., Gülcü, A., \& Keskinocak, P. (2008). Designing optimal preannounced markdowns in the presence of rational customers with multiunit demands. Manufacturing \& Service Operations Management, 10(1), pp. 126-148. DOI: https: //doi.org/10.1287/msom.1070.0157.

Ganesh, J., Reynolds, K.E., \& Luckett, M. (2007). Retail patronage behaviour and shopper typologies: a replication with extension using multi-format, multi-method approach. Journal of the Academy of Marketing Science, Vol 35, pp. 369-381. DOI: https: doi: 10.1007/s11747-007-0038-0.

Geuens, M., Vantomme, D., \& Brengman, M. (2004). Developing a typology of airport shoppers. Tourism Management, 25(5), pp. 615-622. DOI: https: doi:10.1016/j.tourman.2003.07.003.

Harrell, E. (2019, January 23). Neuromarketing: What You Need to Know. Harvard Business Review. https://hbr.org/2019/01/neuromarketing-what-you-need-to-know.

Harris, P.W., Riley, F.D., Riley, D., \& Hand, C. (2017). Online and store patronage: a typology of grocery shoppers. International Journal of Retail \& Distribution Management, 45(4), pp. 419-445. DOI: http://dx.doi.org/10.1108/IJRDM-06-2016-0103.

Hasymova, M. Е. (2016). Дослідження факторів, що впливають на споживчий вибір [Research on factors affecting consumer choice]. The trajectory of science, 12, pp. 39-41[in Ukrainian]. DOI: http://dx.doi.org/10.22178/pos.17-20.

Keiningham, T., Gupta, S. Aksoy, L., \& Buoye, A. (March 18, 2014). The high price of customer satisfaction. MIT Sloan Management Review, Vol. 55, No. 3, pp. 36-46.

Konuş, U., Verhoef, P.C. \& Neslin, S.A. (2008). Multichannel shopper segments and their covariants. Journal of Retailing, 84, 398-413. https://doi.org/(...)j. jretai.2008.09.002.

Kotler, P., \& Pfoertsch, W. (2016). Transformational Sales. Springer.

Koval, L.A. \& Romanchuk, S.A. (2010). Основні аспекти поведінки споживачів і чинників, що зумовлюють вибір певного типу споживацької поведінки [The main aspects of consumer behaviour and factors that determine the choice of a particular type of consumer behaviour]. Scientific papers of Kirovograd National Technical University: Economic sciences, 18, pp. 117-122 [in Ukrainian].

Lambin, J. (2014). Rethinking the Market Economy: New Challenges, New Ideas, New Opportunities. Palgrave Macmillan.

Leung, L. (2015). Validity, reliability, and generalizability in qualitative research. Journal of family medicine and primary care, 4(3), pp. 324-327. 
McNeill, L., \& Moore, R. (2015). Sustainable fashion consumption and the fast fashion conundrum: fashionable consumers and attitudes to sustainability in clothing choice. International Journal of Consumer Studies, 39(3), pp. 212-222. DOI: https://doi.org/10.1111/ijcs.12169.

Nahorskyi, V. (2017, November 13). Аналітика Nielsen: які товари украӥнці купують онлайн [Nielsen Analytics: what goods do Ukrainians buy online]. The Retail Association of Ukraine. https://rau.ua/novyni/nielsen-tovary-pokupayut-onlajn/.

Nilsson, E., Gärling, T., Marell, A. \& Nordvall, A-C. (2015). Who shops groceries where and how? - the relationship between choice of store format and type of grocery shopping. The International Review of Retail, Distribution and Consumer Research, Vol 25, No1, pp. 1-19. DOI: https://doi.org/10.1080/09593969.2014.940996.

Paulssen, M., Brunneder, J., \& Sommerfeld, A. (2019). Customer in-role and extra-role behaviours in a retail setting: The differential roles of customer-company identification and overall satisfaction. European Journal of Marketing, Vol. 53 No. 12, pp. 2501-2529. DOI: https://doi.org/10.1108/EJM-06-2017-0417.

Pysarevskyi, I. M., Nokhrina, L. A., \& Krasnokutska, Yu. V. (2016). Дослідження поведінки споживачів в умовах кризи [Research of consumer behaviour in crisis]. Problems and prospects of entrepreneurship development, 2(2), pp. 23-33 [in Ukrainian].

Ramanathan, U., Subramanian, N. Yu. W., \& Vijaygopal, R. (2017). Impact of customer loyalty and service operations on customer behaviour and firm performance: empirical evidence from UK retail sector. Production Planning \& Control, 28:6-8, pp. 478-488. DOI: https://doi.org/10.1080/09537287.2017.1309707.

Ramanathan, U., Subramanian, N. Yu.W. \& Parrot, G. (2017). Role of social media in retail network operations and marketing to enhance customer satisfaction. International Journal of Operations and Production Management, 37 (1), pp. 105-123. DOI: https://doi.org/10.1108/IJOPM03-2015-0153.

Reddy-Best, K.L., \& Pedersen, E.L. (2015). Queer women`s experiences purchasing clothing and looking for clothing styles. Clothing and Textiles Research Journal, 33(4), pp. 265-279. https://doi.org/10.1177/0887302X15585165.

Reynolds, K. E., \& Beatty, S. E. (1999). A relationship customer typology. Journal of retailing, 75, 509-523. DOI: https://doi.org/10.1016/S0022-4359(99)00016-0.

Saunders, M. N.K. (2011). Research Methods For Business Students, 5/e. Pearson.

Solomon, P. R. (2018). Neuromarketing: Applications, Challenges and Promises. Biomed Journal of Scientific \& Technical Research, 12 (2), pp. 1-11. DOI: https: http://dx.doi.org/10.26717/BJSTR.2018.12.002230.

Stone, G. P. (1954). City shoppers and urban identification: observations on the social psychology of city life. American Journal of Sociology, 60, pp. 36-45. DOI: https://doi.org/10.1086/221483.

System analysis. (n.d.). Golubkov's technique. http://systemsanalysis.ru/golubkov_method.html. Last access: 12.04.2020.

Trout, J. (2008). Differentiate or Die: Survival in Our Era of Killer Competition. Wiley.

Van Vliet, H. (2014). The Fashion Retail scape. CREATE-IT Applied Research, Research Group Crossmedia, Hogeschool van Amsterdam.

Williams, R.H., Painter, J.J., \& Nicholas, H.R. (1978). Policy-oriented typology of grocery shoppers. Journal of Retailing, 54(1), 27-42.

Woodward, S. (2009). The myth of street style. Fashion theory, 13(1), pp. 83-101. DOI: https://doi.org/10.2752/175174109X381355. 


\section{QUESTIONNAIRE}

APPENDIX 1

1. What mostly affects your choice when making purchasing these types of goods?

\begin{tabular}{|l|l|l|l|l|l|l|l|}
\hline \multicolumn{1}{|c|}{ Indicators } & Quality & Price & Brand & Service & $\begin{array}{c}\text { Appea- } \\
\text { rance }\end{array}$ & $\begin{array}{c}\text { Adver- } \\
\text { tising }\end{array}$ & $\begin{array}{c}\text { Other } \\
\text { factors }\end{array}$ \\
\hline Semi-finished goods & & & & & & & \\
\hline Sweets & & & & & & & \\
\hline Alcoholic beverages and tobacco & & & & & & & \\
\hline Mruits, vegetables & & & & & & & \\
\hline Dairy goods & & & & & & & \\
\hline Bread & & & & & & & \\
\hline Household goods & & & & & & & \\
\hline Clothes and shoes & & & & & & & \\
\hline Household appliances & & & & & & & \\
\hline Hygiene goods & & & & & & & \\
\hline Medical goods & & & & & & & \\
\hline Furniture & & & & & & \\
\hline
\end{tabular}

2. Select the characteristics that most accurately describe your behaviour in the store (in a shopping center in the market).

$\square$ If I have saw that everyone are buying this goods, so I am also will buy it.

I quickly choosing the required good.

Always weigh all the "pros" and "cons" before purchasing a good.

Before choose, watching through the whole range of good group.

Before making a purchase, I make a list and follow it clearly.

Often use the seller`s recommendations and consultant services and choose together the good.

Without all the good information, I don`t buy the good.

I use all the discounts all the time also take part in promotions and sales and buy such a good even if I do not need it at all.

$\square$ I often change locations because it is difficult for me to choose a really high-quality good.

$\square$ I go shopping often, but I usually buy almost nothing.

$\square$ I like to always try something new, I am not afraid of change.

Sex: $\quad$ male $\square \quad$ female

Age:

$18-25$ years

26-34 years

$35-45$ years

46-55 years

older 56 years

Which financial class do you refer to?

with a high level of income

with low income

with average income

Source: composed by authors based on Golubkov's technique, M. Saunders and L. Leung researches (System analysis, n.d.; Saunders, 2011; Leung, 2015). 
APPENDIX 2

Survey results (457 persons):

Sample structure:

By gender:

men: 178 persons

women: 279 persons
By age:

18-25 years

26-34 years

$35-45$ years

46-55 years

older 56 years 87
By income level:

73 with average income: 321 persons

105 with a high level of income: 54 persons

100 with low income: 82 persons

\section{Results:}

1. What mostly affects your choice when making purchasing these types of goods?

\begin{tabular}{|l|c|c|c|c|c|c|c|}
\hline \multicolumn{1}{|c|}{ Indicators } & Quality & Price & Brand & Service & $\begin{array}{c}\text { Appea- } \\
\text { rance }\end{array}$ & $\begin{array}{c}\text { Adver- } \\
\text { tising } \\
\text { Other } \\
\text { factors }\end{array}$ \\
\hline Semi-finished goods & 385 & 395 & 20 & & 15 & 11 & 16 \\
\hline Sweets and & 391 & 361 & 14 & 19 & 29 & & \\
\hline $\begin{array}{l}\text { Alcoholic beverages } \\
\text { tobacco }\end{array}$ & 173 & 184 & 287 & & & 37 & \\
\hline Fruits, vegetables & 154 & 243 & & & 348 & & \\
\hline Meat goods & 311 & 388 & & & 18 & 21 & \\
\hline Dairy goods & 365 & 479 & 48 & & & 18 & 10 \\
\hline Bread & 256 & 301 & 31 & 38 & 42 & 14 & 35 \\
\hline Household goods & 143 & 167 & 301 & & & 329 & \\
\hline Clothes and shoes & 372 & 142 & & 322 & & & \\
\hline Household appliances & 172 & 212 & & & & & 252 \\
\hline Hygiene goods & 178 & 201 & & & & & \\
\hline Medical goods & 232 & 55 & 149 & 362 & 210 & & 231 \\
\hline Furniture & & & & & & \\
\hline
\end{tabular}

2. Select the characteristics that most accurately describe your behavior in the store (in a shopping center in the market).

$\square$ (14 persons) If I have saw that everyone is buying this good, so I am also will buy it.

(96 persons) I quickly choose the required good.

(160 persons) Always weigh all the "pros" and "cons" before purchasing a good.

(123 persons) Before choose, watching through the whole range of good group.

(174 persons) Before making a purchase, I make a list and follow it clearly.

(55 persons) Often use the seller`s recommendations and consultant services and choose together the good.

(73 persons) Without all the product information, I don`t buy the good.

(50 persons) I use all the discounts all the time also take part in promotions and sales and buy such a good even if I do not need it at all.

$\square$ (48 persons) I often change locations because it is difficult for me to choose a really high-quality good.

(82 persons) I go shopping often, but I usually buy almost nothing.

(64 persons) I like to always try something new, I am not afraid of change.

Conclusion: Consumer market structure in Chernivtsi region is divers and consists of the following types of consumers:

\begin{tabular}{ccccc}
\hline Innovators & Rationalists & Individualists & Apathetics & Activists \\
\hline $14 \%$ & $38 \%$ & $16 \%$ & $21 \%$ & $11 \%$ \\
\hline
\end{tabular}

Source: composed by authors. 


\title{
CULTURAL COMPLEMENTARITY INDEX AND ITS APPLICATION IN BILATERAL TRADE ANALYSIS, A CASE OF UKRAINE
}

\author{
Lev Vlasenko ${ }^{1}$ \\ ${ }^{1}$ Ph.D (Economics), Assistant Professor of International Economic Relations and Marketing \\ Department, Zaporizhzhya Institute of Economics and Information Technologies (ZIEIT), \\ Zaporizhzhya, Ukraine
}

ORCID ID (D): 0000-0002-7723-1734

\begin{abstract}
The purpose of this study is to estimate the influence of cultural proximity or remoteness of two partner countries on their bilateral trade. To achieve this Cultural complementarity index based on Hofstede's cultural dimensions model is proposed. This index allows fast and reliable ranking of countries according to the overall similarity of their cultural dimensions. To prove the correctness of this proposed index Ukraine's cultural dimensions are compared with 92 countries. Research shows the cultural proximity between Ukraine and Belarus, Russia, Moldova, and other post-Soviet states. By utilizing the panel data of Ukraine's external trade, the proposed index is applied as a variable in the gravity model to test its statistical significance. A strong positive influence of cultural similarity on total bilateral trade is observed, proving the proposed hypothesis.
\end{abstract}

\section{INTRODUCTION}

Cultural economics is one of the fast-growing fields of behavioral economics; it is a branch of economic studies dedicated to the impact of culture on the economic outcomes in production, trade, management, marketing. Among the applications of the study of cultural economics are ideology, religion, social norms, social identity, and social capital.

The role of the cultural factor is particularly and undeniably important in international trade and commerce. The set of commodities consumed in a particular society is shaped by religious taboos, national cuisine, fashion, education, and other factors that are considered cultural by modern socioeconomists (Kalhor et al., 2014). Since the ancient times to conduct their transactions merchants traveled thousands of miles and interacted with various nations speaking numerous languages and practicing different religions. In economic science, culture has been considered a "silent language" of international commerce since 1959 (Hall). Rapid globalization after the end of the Second World War enhanced the role of culture in international economics. The rise of Japan and "Tiger" nations of South-Eastern Asia, modernization of China, and the collapse of the Soviet Union have created a new economic and geopolitical reality where the culture and mentality of Western Europe and its American successor states can no longer be considered synonymous to the capitalism.

In this new reality, behavioral theory in economics is becoming increasingly popular. With the rise of the internet and the standardization of business language as simple English, it is expected that even remote nations will become more engaged in international trade and cooperation (Harms \& Shuvalova, 2019). But no matter what language may be used in a traditional negotiation or via the online conference - it will not nullify the cultural differences in two negotiating parties, their perceptions of profit, beneficial agreement, and fairness that can be entirely different in different cultures.

The goal of this paper is to establish the extent of the influence of the business culture on international trade by introducing the simple Cultural complementarity indexed suitable to analyze bilateral trade on the example of Ukraine.

\section{THEORETICAL FRAMEWORK}

The cultural component of behavioral economics is particularly hard to research because the whole concept of culture is vague and has evolved significantly over time. Culture has been defined in hundreds of ways depending on the nature and goals of the study, selected methods, and theoretical perspectives, including economical ones. To Adam Smith culture was a set of rules of behavior, the 
means by which solidarity between individuals is formed, enabling economic activity (Karimzadi, 2019). According to Geert Hofstede culture is "...the collective programming of the mind which distinguishes the members of one group or category of people from another" (Hofstede, 1991). Modern behavioral economists consider culture as a combination of knowledge, belief, art, ethics, law, tradition, and skills, and other habits which are acquired by people as society members (Kalhor et al., 2014).

But no matter the definition, it is undeniable that cultural differences affect international cooperation and trade, increasing or decreasing transaction costs, making negotiations easier or more difficult, and rendering certain commodities unsellable or demanded depending on the culture of the consumer and supplier (Söderström, 2008).

The role of culture in international trade was researched by many scholars worldwide, for decades, cross-cultural researchers have tried to uncover and explain national cultural differences by applying different methods and approaches. One of the constants in all these various studies is the name of Dutch social psychologist Geert Hofstede, who was the first scholar to conduct empirical cross-country research with measurable cultural values (Sent \& Kroese, 2020).

By analyzing different approaches to business in subsidiaries of a transnational company (IBM in his first research) Geert Hofstede introduced cultural dimensions - certain aspects of culture that can be measured and compared on the national level. When first published in 1980, Hofstede's model of national culture included four dimensions (Hofstede, 1980):

1. Individualism / Collectivism: the extent to which a society emphasizes either the role of the individual or team and group efforts. Individualist societies are more centered on family, while collectivist nations tend to care more about wider "groups" or government. Most individualistic counties in the world are the USA (91), Australia (90), United Kingdom (89); the most collectivistic nations are Bolivia (10), Ecuador (8), Guatemala (6).

2. Power Distance (PDI): the extent to which the less powerful members of a society accept that power is distributed unequally. The acceptance of such inequality means that members of the society desire a hierarchical order in which everybody has a place and which needs no further justification. The countries with the highest Power Distance are Malaysia (100), Slovakia (100), Belarus (95); with the lowest: Denmark (18), Israel (13), Austria (11).

3. Masculinity / Femininity: the preponderance of "masculine" (competitiveness, assertiveness, accomplishments, ambition) or "feminine" (nurturing, sharing, relationships) values in a certain society or a balance between them. Most masculine countries are Slovakia (100), Japan (95), Hungary (88); feminine: Latvia (9), Norway (8), Sweden (5).

4. Uncertainty Avoidance: the degree of tolerance towards uncertainty, the extent to which society prefers structured over unstructured situations. The nations with high uncertainty avoidance levels tend to avoid changes and demonstrate intolerance toward unorthodox behavior or believes. The highest uncertainty avoidance is observed in Greece (100), Portugal (99), Guatemala (98); lowest in Denmark (23), Jamaica (13), Singapore (8).

This four dimension model was later enhanced by studying non-Western countries and companies, particularly so-called "Asian Tigers" (Singapore, Taiwan, South Korea, Hong Kong) and post-socialistic Eastern Europe (Sent \& Kroese, 2020). As a result, two more dimensions were added (Hofstede \& Minkov, 2010):

5. Long-Term Orientation: the extent to which society manages to maintain links with its past and respect for tradition. The difference in term of orientation is a difference between pragmatic (high long-term orientation score) and normative (low score) cultures. The pragmatic cultures believe that truth can change depending on situation and context, while normative society believes in absolute, unchangeable truth. The most pragmatic cultures are South Korea (100), Taiwan (93), Japan (88); normative: Mozambique (11), Egypt (7), Ghana (4).

6. Indulgence / Restrained: the extent to which people control their desires, based on the way they were raised and educated. Indulgent societies express more willingness to have fun and tend to be more optimistic. Restrained nations are generally more pessimistic and focused on controlling their 
desires. Most indulgent societies are Venezuela (100), Mexico (97), Puerto Rico (90); restrained: Ukraine (14), Latvia (13), Egypt (4).

By comparing different countries in these six national culture dimensions, it is possible to determine how close or remote their business environments are. Provided examples demonstrate that there is no evident clear correlation between cultural dimensions, economic, and political systems. One nation may be democratic, feminine, and restrained at the same time, like Latvia, or pragmatic and authoritarian but without the internal need to be structured, like Singapore.

This cultural diversity makes it extremely difficult to compare two countries by using the 6D model. The general view of cultural distance is that as it increases, the costs associated with international trade increase as well (Hofstede, 2001). Meaning that if people of two countries have a substantially different set of values regarding obedience to government, the role of an individual, willingness to cooperate, long-term planning, risk management, and the definition of profit, it is unlikely that they will conduct productive trade transactions because the negotiations process will be complicated and the price of localization for commodities will be unreasonably high.

However, it is also true that even significant cultural differences cannot stop bilateral trade entirely because some types of commodities like raw materials or fuel are universally accepted by any culture and do not have a humane component. This is clearly illustrated by a hermit state of the People's Democratic Republic of Korea that, despite its unique political system, ideology, and culture, is still engaged in trade with more than 100 partners, including a minuscule trade turnover with the USA (International Trade Center, 2021).

Hofstede's research was further enhanced and modified by various scholars across the world, exploring different applications of cultural dimensions, including their impact on international trade.

Jannice Söderström utilized Pythagorean Theorem by using the scores of Hofstede's four culture dimensions to measure the cultural distance between countries and tested the results in the gravity model along with the other institutional factors, including the political stability, effectiveness of government, corruption, and others (Söderström, 2008).

By using Hofstede's dimensions and the index developed by Kogut and Singh (1988) to measure a culture distance and by including the result in the gravity model, Lankhuizen \& de Groot (2014) established that trade and cultural distance have a non-linear relationship, meaning that the international trade decreases with cultural distance once cultural differences between two countries surpass a certain threshold.

Ahmed Driouchi used Hofstede dimensions to analyze flaws in the knowledge economy of Arab countries. In his studies, he examines the state of human capital in the Middle East and by using regression analysis compares it to the Eastern European countries. His research indicates that Eastern European countries create more opportunities for the younger generation and new business startups, while Arab countries suffer from several setbacks that can be explained by power distance, inequality, the excessive role of tradition, and trade barriers (Driouchi, 2015).

A unique method of measuring cultural and institutional distance based on the same Kogut and Singh (1988) index was proposed by James Aylward (2016) to study the role of cultural and institutional differences across European countries in explaining patterns of bilateral trade within Europe. This topic was further explored by Harms \& Shuvalova (2016) by applying the parameters of cultural distance and the remoteness in the regression equations to determine the importance of the cultural factor in trade in services.

A group of scientists from the University of Iceland proposed to use the combined value of five cultural dimensions as a Hofstede cultural index and estimated the effects of each separate dimension on international trade by applying the gravity model. According to the results, only the masculinity dimension significantly affected international trade, however, only 21 countries were included in the model (Kristjánsdóttir et al., 2017).

Cultural impact on trade is a particularly important topic for contemporary Ukraine. In 2014 Ukraine signed an Association Agreement with European Union, hoping it will boost Ukraine-EU bilateral trade turnover and will be highly profitable for Ukrainian exporters. The success or failure 
of the reforms that are currently undergoing in Ukraine is highly dependent on the complementarity of its trade portfolio with the EU and the ability to negotiate better deals with European partners. On the other hand, EU authorities are reluctant to expand cooperation with Ukraine until the business environment in this country meets European standards (European Commission, 2021).

Cultural dimensions and business culture were researched by Ukrainian scholars mostly to compare the business environment of Ukraine with other countries. Ukrainian and Polish business cultures were compared by using Hofstede's classification, outlining similarities and differences between two countries in a study conducted by Wackowski \& Blyznyuk (2017). Cross-cultural communications in the business of Ukrainian and Romanian companies was a topic of research by Lifintsev \& State (2019). In that study, bilateral trade in commodities of two countries was mentioned, and a comparison of six cultural dimensions was conducted, but the connection between trade and culture was not discussed beyond the statement that it is affected by the socialist past of both nations.

However, a detailed analysis of the complementarity of Ukrainian business culture with the European Union and its influence on bilateral trade was yet to be conducted by any Ukrainian or foreign scholar. To fill this gap, this study will closely examine the similarity of cultural dimensions of Ukraine and its partners both inside and outside the European Union and the connection between cultural similarity and values of total trade.

\section{METHODS}

This study proposes a new way for calculating the composite index based on Hofstede's theory. The idea behind this method is to use one aggregated indicator based on six cultural dimensions to quickly determine the position of a certain country in the wide general dataset or to use it in an econometric model as a single variable. formula:

The introduced Cultural complementarity index (CCI) index is calculated by the following

$$
\mathrm{CCI}_{\mathrm{ij}}=100-\left[\frac{1}{6} \sum_{u=1,2 \ldots 6}^{6}\left|\mathrm{I}_{\mathrm{ui}}-\mathrm{I}_{\mathrm{uj}}\right|\right],
$$

where, $i$ and $j$ are the countries of interest; $I$ is the value of one of the 6 Hofstede's cultural dimensions, namely: $\mathrm{u} 1$ - power distance (PDI); $\mathrm{u} 2$ - individualism (IDV); u3 - masculinity (MAS); $\mathrm{u} 4$ - uncertainty avoidance (UAI); u5 - long-term orientation (LTO); u6 - indulgence (IND).

The proposed index may take a value between 1 (maximum cultural distance) and 100 (maximum similarity of business cultures). However, values lower than 40 are highly unlikely because low scores of all six cultural dimensions simultaneously are not observed in any country researched by Hofstede Insight organization.

The proposed index has several limitations: to simplify the calculation and usage of the index it is assumed that all cultural dimensions have similar weight and thus equally affect economic cooperation. Because of this, it is recommended to use the index only for general ranking before examining each particular pair of partner countries in greater detail. 


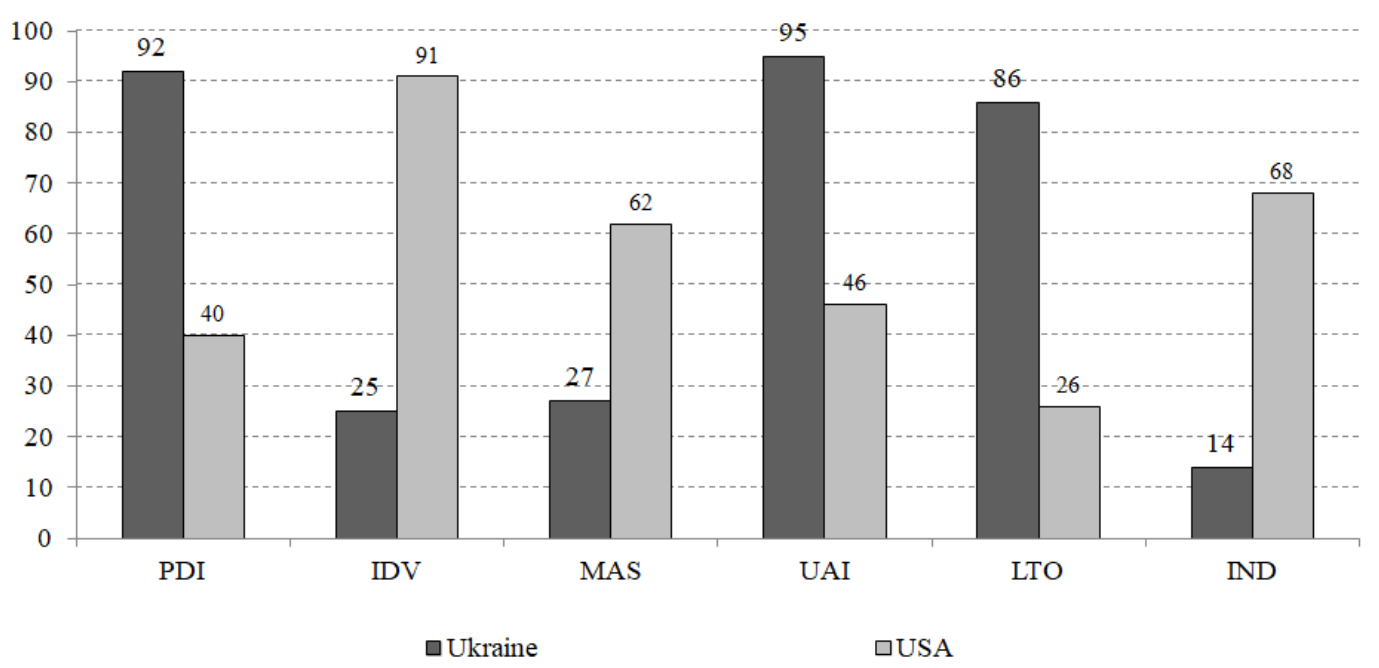

Fig. 1. Hofstede's cultural dimensions of Ukraine and the USA

Source: Hofstede Insights, 2021

For example, if we compare Ukraine to the United States (see cultural dimensions of both countries in fig. 1), the calculation of their cultural complementarity will take the following form:

$$
\begin{gathered}
\mathrm{CCI}_{\mathrm{ij}}=100-\left[\frac{|92-40|+|25-91|+|27-62|+|95-46|+|86-26|+|14-68|}{6}\right]= \\
=100-\left[\frac{316}{6}\right]=47.333 \ldots
\end{gathered}
$$

To test the significance and usefulness of the proposed Index the results of the calculations were included in the simple gravity model equation.

The gravity model of trade was introduced in 1954 by Walter Isard and further modified by Dutch economist Jan Tinbergen (1962). The idea of the model is the prediction of trade depending on the size of economies of two partner countries (usually measured as their Nominal GDP) and the geographical distance between them (usually measured as the distance between two capitals). Originally the gravity equation of international trade was introduced by Isard (1954) in the following formula:

$$
T_{i j}=G \times \frac{Y_{i} \times Y_{j}}{D_{i j}} \varepsilon_{i j}
$$

where $T_{i j}$ stands for the total trade between countries $i$ and $j ; Y_{i}, Y_{j}$ stands for the GDP of the respected countries; $D_{i j}$ for the distance between them in kilometers; $G$ for the gravity constant (the theorized influence of the gravity force similar to the Newtonian gravity); $\varepsilon_{i j}$ for an error term with expectation equal to 1 . The general theory behind the model is that size matters in international trade, and the larger economies are, the more probability that they will be engaged in bilateral trade (Söderström, 2008). However, there is also a somewhat contradictory statement that a small economy cannot provide for all its needs and is more dependent on foreign trade than a larger economy that theoretically can be self-sufficient by using its vast resources (Krugman 1991).

In further research, the Tinbergen model was repeatedly expanded by various scholars by adding new indicators and dummy variables such as population, language distance, institutional factors, etc. Including new components in the gravity model is a common way to test whether or not this certain variable affects bilateral trade. According to the United Nation's Economic and Social Commission for Asia and the Pacific (ESCAP) user guide, the gravity model of trade provides a 
"convenient testing bed" to assess the trade impacts of different variables (Shepherd, Doytchinova, et al., 2019).

In this study, the total trade of Ukraine with a certain trade partner is selected as the dependent variable. Total trade (or trade turnover) is calculated as the sum of country exports and imports. The basic gravity model used to test the significance of the proposed Cultural complementarity index on the example of Ukraine will take the following form:

$$
L n T_{i j}=\alpha_{0}+\alpha_{1} \ln \left(Y_{i t}\right)+\alpha_{2} \ln \left(Y_{j t}\right)+\alpha_{3} \ln \left(D_{i j}\right)+\alpha_{4} \ln \left(C I I_{i j}\right)+\varepsilon
$$

where $T_{i j}$ - is the total of trade (sum of export and import) between country $i$ and $j$ (in this article $i$ stands for Ukraine); $t$ - is a year of data in each example (from 2010 to 2020); $Y_{i}, Y_{j}$ - is the Nominal Gross Domestic Product; $D_{i j}$ - is the distance (in kilometers) between Ukraine and the specific trade partner; $C I I_{i j}$ - is the Cultural complementarity index; $\varepsilon$ - is an error term.

The analysis covers a period of 2010-2020. The distance between countries is calculated as a distance between their capitals. There is an assumption that the cultural dimensions of all analyzed countries remained unchanged for a decade. It is reasonable to assume that raw materials will be less affected by cultural differences between countries while consumers, high-tech, cultural goods, and services will be the most affected. In this study, there is an assumption that all cultural dimensions have a similar influence on all types of commodities no matter their stage of processing and nature.

Considering the limitations and economical orientation of Hofstede's theory, it needs to be noted that the proposed index takes into account only the business organizational culture and cannot be considered as a general indicator of cultural similarity of different nations. The index does not replace by any means such well-established variables of the gravity model of trade as language, religion, diaspora, colonial past, etc.

\section{ANALYSIS OF RESULTS}

Within the framework of this research, the Cultural complementarity index (CCI) was calculated for Ukraine and 92 partner countries by using the values of cultural dimensions available on the Hofstede Insight official website. Only those countries where data on all six cultural dimensions were available were included in the calculation. The results of the calculation of the proposed Index are shown in table 1 and illustrated in Fig. 2.

The results of the analysis show that the cultures of Belarus (97.33), the Russian Federation (94.17), and Moldova (94) are the most similar to Ukraine. This is expected due to the common economic and historical past of the post-Soviet countries and similar market transformations taking place in the business environment of all post-socialistic countries. The least complementary to Ukraine is the business cultures of the USA (47.33), Australia (46.83), and Ireland (46.17). The lack of cultural complementarity with the USA, certain countries of Western Europe, and the British Commonwealth is explained by the relatively low values of individualism (IDV) and high power distance (PDI) in Ukraine.

The CCI score with 25 nations of the European Union besides Ireland (Hofstede's dimensions on Cyprus is not available) are following: Austria (56.17), Belgium (74.67), Bulgaria (88.5), Croatia (83), Czech Republic (75), Denmark (47.83), Estonia (78.17), France (74.67), Finland (62.5), Germany (67.17), Greece (74.33), Hungary (63.33), Italy (67.17), Latvia (73.17), Lithuania (78.5), Luxemburg (66.83), Malta (69.66), Netherlands (60.5), Poland (73.17), Portugal (80.67), Romania (88.83), Slovakia (70.83), Slovenia (81.83), Spain (74.5), Sweden (51.33).

The average value for Ukraine-EU CCI is 70.32. This is slightly lower than the world average CCI indicator for Ukraine (71.35). This may pose a problem for Ukraine because this country is currently positioning itself as a part of the European cultural platform and is aimed to enter European Union as soon as possible. 
Table 1. Cultural complementarity index of Ukraine and selected partners

\begin{tabular}{|c|c|c|c|c|c|c|c|c|}
\hline \multirow{2}{*}{ № } & \multirow{2}{*}{ Country } & \multicolumn{6}{|c|}{ Hofstede's model cultural dimensions } & \multirow{2}{*}{$\mathrm{CCI}_{\mathrm{ij}}$} \\
\hline & & PDI & IDV & MAS & UAI & LTO & IND & \\
\hline- & Ukraine & 92 & 25 & 27 & 95 & 86 & 14 & 100 \\
\hline 1 & Belarus & 95 & 25 & 20 & 95 & 81 & 15 & 97.33 \\
\hline 2 & Russia & 93 & 39 & 36 & 95 & 81 & 20 & 94.17 \\
\hline 3 & Moldova & 90 & 27 & 39 & 95 & 71 & 19 & 94 \\
\hline 4 & Kazakhstan & 88 & 20 & 50 & 88 & 85 & 22 & 92 \\
\hline 5 & Montenegro & 88 & 24 & 48 & 90 & 75 & 20 & 92 \\
\hline 6 & Romania & 90 & 30 & 42 & 90 & 52 & 20 & 88.83 \\
\hline 7 & Bulgaria & 70 & 30 & 40 & 85 & 69 & 16 & 88.5 \\
\hline 8 & Azerbaijan & 85 & 22 & 50 & 88 & 61 & 22 & 87.83 \\
\hline 9 & Serbia & 86 & 25 & 43 & 92 & 52 & 28 & 87.83 \\
\hline 10 & Armenia & 85 & 22 & 50 & 88 & 61 & 25 & 87.33 \\
\hline \multicolumn{9}{|c|}{ [11-82] } \\
\hline 83 & South Africa & 49 & 65 & 63 & 49 & 34 & 63 & 55.67 \\
\hline 84 & Iceland & 30 & 60 & 10 & 50 & 28 & 67 & 55 \\
\hline 85 & Canada & 39 & 80 & 52 & 48 & 36 & 68 & 52.66 \\
\hline 86 & Sweden & 31 & 71 & 5 & 29 & 53 & 78 & 51.33 \\
\hline 87 & UK & 35 & 89 & 66 & 35 & 51 & 69 & 48.33 \\
\hline 88 & Denmark & 18 & 74 & 16 & 23 & 35 & 70 & 47.83 \\
\hline 89 & New Zealand & 22 & 79 & 58 & 49 & 33 & 75 & 47.5 \\
\hline 90 & USA & 40 & 91 & 62 & 46 & 26 & 68 & 47.33 \\
\hline 91 & Australia & 38 & 90 & 61 & 51 & 21 & 71 & 46.83 \\
\hline 92 & Ireland & 28 & 70 & 68 & 35 & 24 & 65 & 46.17 \\
\hline
\end{tabular}

Source: Hofstede Insights, 2021; Author's calculations.

A low level of cultural complementarity may explain the failure of the market reforms in Ukraine and the reluctance of a certain part of its population to accept the proposed course on European integration. The expected and true-to-life result of the index is not a coincidence in the case of Ukraine. If applied to the People's Republic of China the proposed Index will show that culturally closest to China are Hong Kong (90), Vietnam (87.16), and Singapore (86.16).

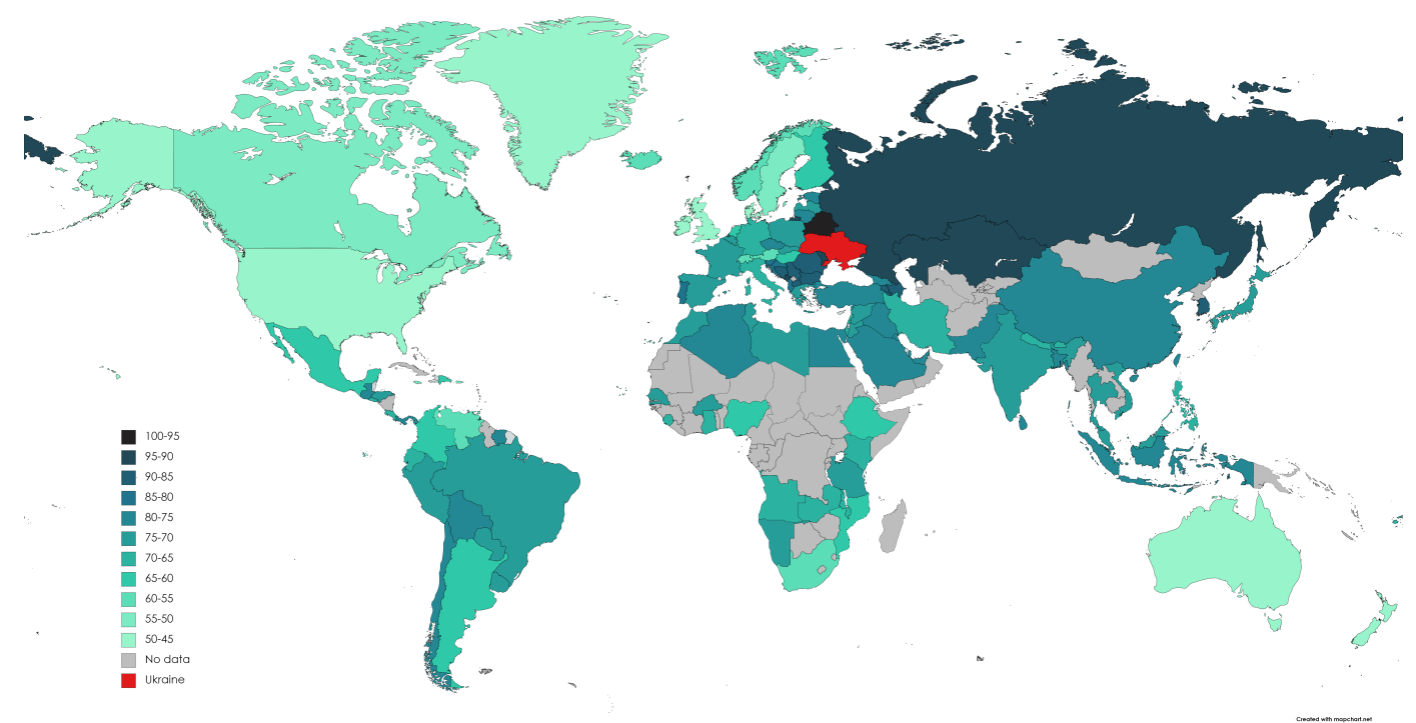

Fig. 2. Map of cultural complementarity of Ukraine Source: Hofstede Insights, 2021; MapCharts; Author's calculations 
If applied to Germany: Switzerland (92), Luxemburg (88.6), and Italy (88.33). In all examples, the tested country demonstrated high cultural complementarity to partners with the same type of economic order or populated by the same or related ethnic group while the least complementarity was observed when pairing a country with a partner from another political-economical system populated by different people speaking a vastly different language, as in the case of Iraq and Sweden (47.5). This proves that the Cultural complementarity index can be a simple and reliable method of comparing and ranking countries in terms of their business culture proximity or remoteness.

To test whether and to what extent the proposed index explains bilateral trade, it was included in the log-log equation according to the abovementioned method. Data for GDP was obtained from International Monetary Fund's website. Google Map services were used to measure the geographical distance. Export and import values were retrieved from the International Trade Center. The regression results are presented in Table 2.

Table 2. Result of the estimation of the proposed gravity model

\begin{tabular}{|c|c|c|c|c|c|}
\hline Variable & Description & Coefficient & Std. Error & $\mathrm{t}$ & $\mathrm{P}$ \\
\hline $\operatorname{Ln}\left(Y_{i t}\right)$ & GDP of Ukraine & 0.7771504 & 0.1560085 & 4.98 & 0.000 \\
\hline $\operatorname{Ln}\left(Y_{j t}\right)$ & $\begin{array}{c}\text { GDP of } j \text {-partner in bilateral } \\
\text { trade }\end{array}$ & 1.016892 & 0.0196834 & 51.66 & 0.000 \\
\hline $\operatorname{Ln}\left(D_{i j}\right)$ & Geographical distance & -1.434865 & 0.0381844 & -37.58 & 0.000 \\
\hline $\operatorname{Ln}\left(C C I_{i j}\right)$ & Cultural complementarity index & 2.343274 & 0.2238663 & 10.47 & 0.000 \\
\hline- & Constant & -25.44761 & 4.167484 & -6.08 & 0.000 \\
\hline- & Number of observations & 996 & - & - & - \\
\hline- & R-squared & 0.8005 & - & - & - \\
\hline
\end{tabular}

Source: Author's calculations.

$\mathrm{R}$-squared is equal to 0.8005 , which indicates that this regression explains 80 percent of the variations in the dependent variable (total trade), meaning that the result of this regression can be considered statistically reliable. According to the result of the regression, all selected independent variables proved to be significant. Holding all other variables constant, a $1 \%$ growth in GDP of Ukraine will result in a $0.777 \%$ change in total trade with the respected partner country, and $1 \%$ growth in GDP of a partner country will result in a $1.016 \%$ change in total trade making the economy size of a partner country more significant. The proposed Cultural complementarity index has a strong positive impact on bilateral total trade with a coefficient of 2.343274 , meaning that a $1 \%$ increase in CCI may cause up to a $2.34 \%$ increase in total trade with the respective partner. All variables show a positive effect on total trade except for distance which, as expected, has a negative effect on the amount of trade. A $1 \%$ positive change in geographical distance will result in a loss of $1.4 \%$ of total trade with the respected partner.

Thus, other things being equal, it is evident that the volume of trade between the two countries is higher if they have a similar business environment measured by Hofstede's six cultural dimensions. The proposed Cultural complementarity index yields a positive impact on bilateral total trade and proves to be highly significant.

\section{CONCLUSION}

In this study, a new method of measuring cultural distance based on Hofstede's cultural dimensions model was proposed. The method is based on a calculation of a simple aggregate index designed to display six cultural dimensions as one variable. To test the proposed index it was calculated for Ukraine and its 92 partner countries in bilateral trade providing true-to-life reliable results.

According to the obtained values of the index, the countries closest to Ukraine in terms of the cultural environment of business are Belarus, Russia, Moldova, and other post-Soviet republics. This can be explained by the close historical ties, the ethnic composition of the population, and similar processes ongoing in the transitional economies of all post-socialistic nations. The most culturally 
distant from Ukraine are the countries of Western Europe and the United States. The reason for this is mainly the low level of individualism and high power distance in modern Ukrainian business culture. To promote European integration and liberalization of the Ukrainian economy these issues must be addressed and resolved.

By utilizing the panel data of Ukraine's external trade the proposed index is applied as a variable in the gravity model of trade to test its statistical significance. A strong positive influence of cultural similarity on total bilateral trade is observed proving the proposed hypothesis.

The results of the conducted research indicate that the proposed Cultural complementarity index adequately indicates the similarity of organizational business culture in two partner countries. The main advantage of the proposed method is simplicity and accuracy. It requires only six cultural dimensions and simple math to establish the proximity and remoteness of two countries and is reliable enough to be included in gravity equations and other methods of econometric modeling.

\section{REFERENCES}

Aylward, J. (2016). The Impact of Culture, Institutions, and the Euro on Trade Flows in Europe. Undergraduate. Economic Review: Vol. 13: Iss. 1, Article 6. Available at: http://digitalcommons.iwu.edu/uer/vol13/iss1/6

Driouchi, A. (2015). Hofstede Index and Knowledge Economy Imperfections in Arab Countries. MPRA Paper 67365, University Library of Munich, Germany.

European Commission. Ukraine: EU report notes continued implementation of the reform agenda though challenges remain. Official web-site. Retrieved May, 2021, from https://ec.europa.eu/commission/presscorner/detail/en/ip_20_2259

Hall, E. T. (1959). The silent language. Garden City, N.Y: Doubleday.

Harms., P \& Shuvalova, D. (2016). Cultural Distance and International Trade in Services: A Disaggregate View. Working Papers 1606, Gutenberg School of Management and Economics, Johannes Gutenberg-Universität Mainz.

Helga Kristjánsdóttir, Pórhallur Örn Guðlaugsson, Svala Guðmundsdóttir \& Gylfi Dalmann Aðalsteinsson (2017). Hofstede national culture and international trade, Applied Economics. doi: 10.1080/00036846.2017.1343446

Hofstede Insights. Official web-site. Retrieved May, 2021, from https://www.hofstedeinsights.com/

Hofstede, G. (1980). Culture's Consequences: International Differences in Work-Related Values, 1st ed., Beverly Hills, CA: Sage.

Hofstede, G. (1991). Cultures and organizations: Software of the mind. London: McGraw-Hill.

Hofstede, G. (2001). Culture's Consequences - Comparing Values, Behaviours, Institutions, and Organizations Across Nations. London: Sage Publications Ltd.

Hofstede, G., Hofstede G. J. \& Minkov M. (2010). Cultures and Organizations, Software of the Mind: Intercultural Cooperation and its Importance for Survival (3rd edn), New York: McGraw-Hill.

International Monetary Fund. Official web-site. Retrieved March, 2020, from https://www.imf.org

International Trade Center. Official web-site. Retrieved May, 2021, from http://www.trademap.org

Isard, W. (1954). Location Theory and Trade Theory: Short-Run Analysis. Quarterly Journal of Economics. 68 (2), 305-320. doi: 10.2307/1884452

Kalhor, A., Shahi, H., \& Horri, M. S. (2014). Effect of culture on international trade: case study of saffron export. Indian J. Sci. Res, 4(6), 381-388.

Karimzadi, S. (2019). Culture in Economics. Advances in economics and business, 7, 8-14.

Kogut, B. \& Singh, H. (1988). The effect of national culture on the choice of entry mode. J. Int. Bus. Stud. 19, 411-432. 
Krugman, P. (1991). Increasing Returns and Economic Geography. The Journal of Political Economy 99 (3): 483-499.

Lankhuizen, M.B.M., de Groot, H.L.F. (2016). Cultural distance and international trade: a nonlinear relationship. Lett Spat Resour Sci 9, 19-25. doi: 10.1007/s12076-014-0129-8

Lifintsev, D. \& State M. (2019). Cross-cultural communication in business: recommendations for Ukrainian companies trading with partners from Romania. International Scientific and Practical Internet Conference "Business strategy: futurological challenges". Kyiv, Ukraine.

Sent, E., \& Kroese, A. (2020). Commemorating Geert Hofstede, a pioneer in the study of culture and institutions. Journal of Institutional Economics, 1-13. doi: 10.1017/S174413742000051X

Shepherd, B., Doytchinova, H. S. \& Kravchenko, A. (2019). The gravity model of international trade: a user guide [R version]. Bangkok: United Nations ESCAP. Available at: https://www.unescap.org/resources/gravity-model-international-trade-user-guide-r-version

Soderstrom, J. (2008). Cultural Distance: An Assetment of Cultural Effect of Trade Flows. Jonkomping International Business School, Jonkomping University.

Tinbergen, J. (1962). Shaping the World Economy: An Analysis of World Trade Flows. New York Twentieth Century Fund, Vol. 5, No. 1. - pp. 27-30.

Wackowski, K., Blyznyuk, T. (2017). Modern Ukrainian and Polish business cultures: G. Hofstede's classification. Ekonomichny chasopys-XXI 165 (5-6): 71-74. 


\title{
PERSPECTIVES ON THE IMPACT OF MIGRATION RISKS ON THE STATE ECONOMY
}

\author{
Svitlana Berezina ${ }^{1}$, Vladyslava Konotopets ${ }^{2}$ \\ ${ }^{1}$ D. Sc. (economics), assoc. prof., prof., the Insurance, Banking and Risk Management Department, \\ Taras Shevchenko National University of Kyiv, Director of The Center for Innovative Development, \\ Taras Shevchenko National University of Kyiv, Kyiv, Ukraine \\ ${ }^{2}$ M. (philology), Taras Shevchenko National University of Kyiv, leading specialist, The Center for Innovative \\ Development, Taras Shevchenko National University of Kyiv, Kyiv, Ukraine \\ ORCID ID : :0000-0002-9737-0651; 0000-0002-5947-9891
}

\begin{abstract}
The article is devoted to the study of the dynamics and structure of external labor migration from Ukraine, the major causes and consequences of migration flows, the identification of risks of a skilled labor drain for the socio-economic development of Ukraine. The study found that Ukraine is characterized by increasing scale of external labor migration, primarily of young people and skilled workers, which affects both the economically active population in general and the number of scientific personnel, which until recently constituted a significant scientific and technological personnel potential of the country. Have been highlighted driving, political, social, environmental and globalization factors of increased external labour migration. Considering the identified negative trends affecting the domestic labour market and economic growth, it is concluded that state migration policy should be revised to prevent circular labour migration from turning into emigration, which leads to irreversible loss of population.
\end{abstract}

\section{INTRODUCTION}

Globalisation is constantly transforming the international labour market and international labour migration is a major factor in its development. World leaders, applying a selective approach and clearly defining priorities, tend to use international migration as an important factor in the development of the economy, national human capital and the entire social sphere. A bright example is the USA, where highly skilled immigrants promote the development of science, high technology, medicine, etc., while low-skilled workers from other countries provide cheap labor for small and medium-sized businesses. Countries such as Canada, Australia, New Zealand, Israel, England and Germany are not left out.

However, the intensification of migration processes has ambiguous consequences for donor countries. It poses serious strategic risks to the development of national economies. In the process of external migration an unequal exchange of human resources takes place. Thus, the outflow of migrants from Ukraine is represented mainly by skilled workers and specialists, most of whom are employed in European Union countries, increases imbalances between supply and demand on the domestic labour market with consequent wage increases and local shortages of skilled workers, holding back economic growth. Ukrainian young people are actively involved in global migration processes and actively travel abroad for study and work purposes.

Global experience shows the cumulative nature of the risk of excessive migration processes, to which migration starts significantly limiting economic development after 5-7 years. Ukraine is already approaching a critical loss of labour capital. In this regard, becomes more relevant the problem of improving the system of regulation of international labour migration, based on: continuous monitoring of the dynamics and structure of migration processes, identification of significant factors contributing to labour outflow from the country, assessment of the degree of negative consequences for the economy, demography and social sphere, as well as development of state policy measures for the regulation of migration flows aimed at neutralizing the risks caused by these processes. 
The object of the paper is to investigate the migration situation in Ukraine and to identify its trends and prospects of its impact on the state economy.

The purpose of the paper is to research the dynamics and structure of external labor migration from Ukraine, to reveal the main causes and consequences of migration flows and to identify the risks of the outflow of skilled workers for the socio-economic development of the country.

\section{LITERATURE ANALYSIS}

External migration problems and their impact on the labour market are now the focus of consideration of a significant number of domestic and foreign researchers, including: Haidutskyi (2018), Kvasha (2018), Kolot (2018), Libanova (2018), Lisogor, Tsymbal, Yarosh (2016), Malynovska (2018), Poznyak (2016), Romanyuk (2018), Sadova (2018), Smaliychuk (2017), Athukorala (2006), Belanger, Ueno, Hong, Ochiai (2011), Midori (2018), Fee, Rahman (2006), Komine (2018), Yasushi (2012), Hosogaya (2020), Oishi (2012), Deborah (2020), Ruhs (2013), Ford, Kawashima (2012) among others. However, a number of issues related to the assessment of risks of skilled migration from Ukraine, which is complicated by the reflection of real external migration flows on the basis of domestic statistics, remain understudied what is indicated by the lack of constructive state policy approaches to the regulation of external labour migration processes.

\section{METHODS}

In order to achieve the purpose of the research and implement the set goals, theoretical research methods were used. Namely they are: theoretical generalisation, structurisation, systematic and statistical analysis, comparison, analogy, classification and others.

\section{RESULTS \\ 1. THE DYNAMICS OF MIGRATION PROCESSES IN UKRAINE}

In Ukraine labour migration abroad is the most significant flow of migrants. Due to the freedom of movement obtained during the period of independence under difficult economic circumstances and low wages, work abroad has become for many Ukrainians a strategy for survival and improvement of the well-being of their families (Malynovska, 2018). It is a powerful social shock absorber, a factor in reducing poverty and tensions in the labour market, a source of significant foreign exchange earnings, but at the same time it entails the risk of losing part of the labour and intellectual potential necessary for the development of the country. The share of Ukraine's economically active population is decreasing every year. According to data from the State Statistical Service, in 2018, almost 28\% (11,7 million) of the 42 million population were pensioners, another $26 \%$ (11 million) were economically inactive (according to the ILO classification, this is the population aged 15-70 who do not belong in the "employed" or "unemployed" categories), and about 7-10\% (3-5 million) work abroad. This leaves only about 15 million (36\%) economically active people. This is three times less than in Germany (about 45 million) (Haidutskyi, 2018), although the Ukrainian population is officially only half as large. However, many experts believe that the real population is smaller than the statistics show.

But according to the official data of the State Statistical Service (Table 1), a positive migration balance is stable in Ukraine, as the number of arrivals to Ukraine prevails over the number of departures (according to this data for the last 12 years 230000 more people arrived in the country than left).

At the same time, according to UN data (United Nations, Department of Economic and Social Affairs, Population Division, 2017), Ukraine belongs to the top ten countries with the largest number of emigrants, and this number has increased in recent years. The State Statistics Service estimates the number of labour migrants at 1,3 million, while experts cite estimates of 2 to 4 million people. 
Table 1. Ukraine's demographic indicators

\begin{tabular}{|l|c|c|c|c|c|c|c|c|c|}
\hline Indicators & 2010 & 2011 & 2012 & 2013 & 2014 & $2015^{*}$ & $2016^{*}$ & 2017 & 2018 \\
\hline $\begin{array}{l}\text { Number of } \\
\text { permanent } \\
\text { population (end } \\
\text { of year), } \\
\text { thousand } \\
\text { people }\end{array}$ & $\begin{array}{c}45598, \\
2\end{array}$ & $\begin{array}{c}45453, \\
3\end{array}$ & $\begin{array}{c}45372, \\
7\end{array}$ & $\begin{array}{c}45245, \\
9\end{array}$ & $\begin{array}{c}42759, \\
7\end{array}$ & $\begin{array}{c}42590, \\
9\end{array}$ & $\begin{array}{c}42414, \\
9\end{array}$ & $\begin{array}{c}42216, \\
8\end{array}$ & $\begin{array}{c}41983, \\
6\end{array}$ \\
\hline $\begin{array}{l}\text { Number of } \\
\text { arrived, } \\
\text { thousand people }\end{array}$ & 683,4 & 669,4 & 726,3 & 675,9 & 542,5 & 533,3 & 256,8 & 442,3 & 629,3 \\
\hline $\begin{array}{l}\text { Number of } \\
\text { departured, } \\
\text { thousand people }\end{array}$ & 667,3 & 652,3 & 664,4 & 644,0 & 519,9 & 519,1 & 246,2 & 430,3 & 610,7 \\
\hline $\begin{array}{l}\text { Migration } \\
\text { growth, } \\
\text { decrease (-), } \\
\text { thousand people }\end{array}$ & 16,1 & 17,1 & 61,8 & 31,9 & 22,6 & 14,2 & 10,6 & 12,0 & 18,6 \\
\hline
\end{tabular}

* - excluding the temporarily occupied territory of the Autonomous Republic of Crimea, the city of Sevastopol and part of the area of the United Forces operation.

Source: Constructed by the authors based on (The State Statistics Service of Ukraine, 2010-2018)

According to the Ministry of Social Policy of Ukraine, an average of 7 to 9 million people per year are involved in the migration process, with only 3,2 million labour migrants from Ukraine staying abroad permanently, daily during the year (Ministry of Social Policy named the exact number of Ukrainian labor migrants, 2018). According to the State Border Guard Service, between 2008 and 2017, 3,7 million citizens left Ukraine and did not return (Financial Stability Report, 2018). The Ministry of Foreign Affairs also notes that Ukraine is losing population at a rapid pace; every year more than one million Ukrainian citizens leave the country and go to neighbouring countries, noting that this situation will continue in the near future. Thus, according to the minister, according to the latest data, in Poland alone about 1,4 million Ukrainians are living. Most Ukrainians go abroad to work and settle in the near abroad, but many go even further to Europe and America in search of a better life (Catastrophic situation: a million citizens leave Ukraine every year, 2018). These discrepancies in migration estimates may be caused by different definitions of "migrant" as well as by different methods of data collection. That is, different data sources indicate opposite trends in migration from Ukraine. UN data based on immigration estimates show that the number of Ukrainians abroad is constantly increasing, while the number of foreigners remaining in Ukraine decreased in the first 15 years of independence and then remained almost at the same level (Figure 1).

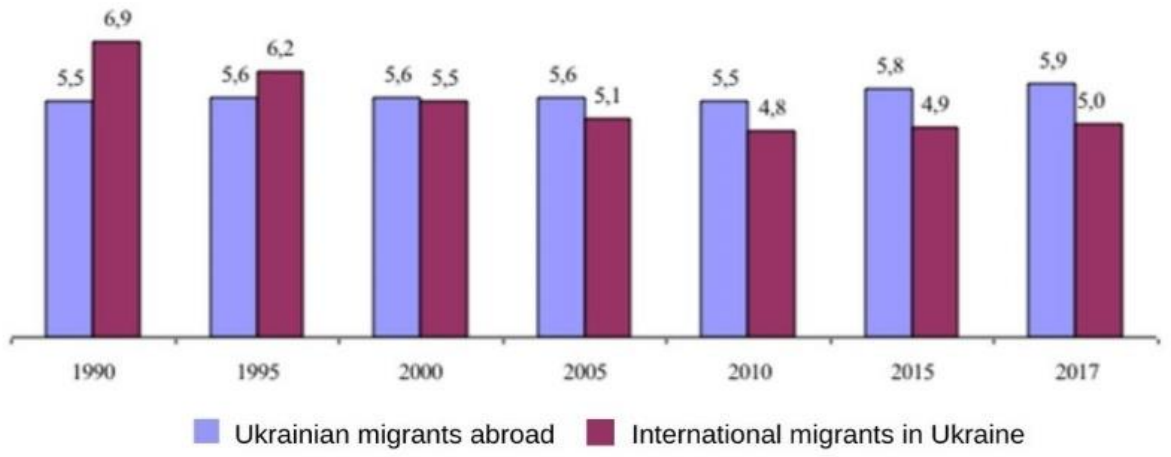

Fig. 1. Number of migrants according to UN estimates, million people

Source: (United Nations, Department of Economic and Social Affairs, Population Division, 2017) 
At the time of independence, as the UN data shows, migration directions of Ukrainians have changed significantly. In the first years of independence, almost $85 \%$ of Ukrainian emigrants lived in countries of the former Soviet Union (mostly people who were born in the USSR and at some time moved to live in another republic of the Union). In 27 years the number of Ukrainians in these countries has decreased from 4,6 to $4,1 \mathrm{mln}$ and their share in the total number of migrants - to $70 \%$. The number of Ukrainian emigrants in the USA, Canada, Western and Central Europe and Australia has increased from 0,7 to 1,6 million and their share in the total number of Ukrainians who went to live abroad has risen from $13 \%$ to $27 \%$.

More than half of Ukrainian migrants - over 3 million - live in Russia. During the first decade of independence their number was growing (Figure 2). Then the Russian Federation became less attractive for Ukrainians - their number decreased by almost $15 \%$. Russian military aggression against Ukraine triggered a new wave of emigration - the number of Ukrainians living in Russia increased from 3 to 3,3 million people.

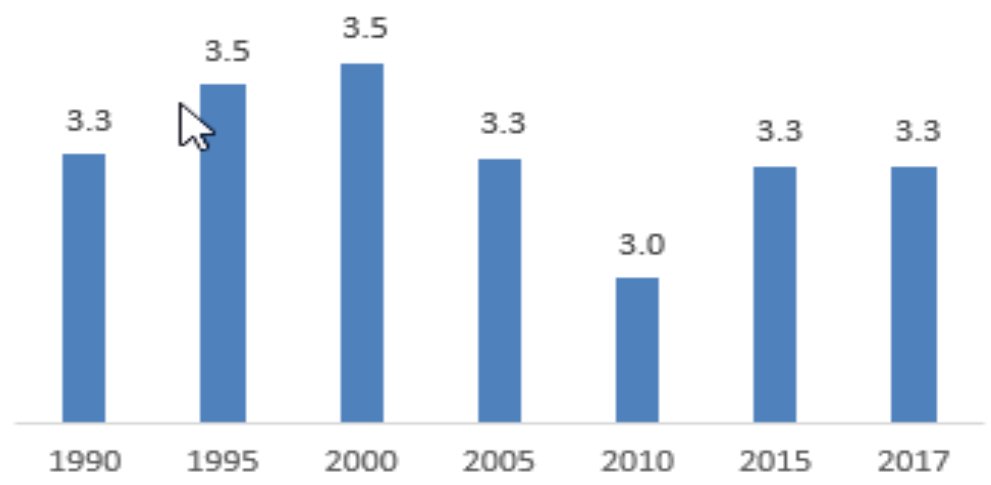

Fig. 2. Number of Ukrainian migrants in the Russian Federation, million people

Source: (United Nations, Department of Economic and Social Affairs, Population Division, 2017)

Estimates of the number of labour migrants in Ukraine also vary. For example, the International Organisation for Migration (IOM) estimates their number at 688,000 people (Migration in Ukraine: facts and figures, 2016).

The State Statistics Service periodically conducts a survey to determine the number of labour migrants according to ILO methodology. According to the results of the last survey, which concerned 2015-2017, SES estimates the number of labour migrants at 1,3 million people (about $8 \%$ of the employed population). These figures are also doubted by experts (How many Ukrainians went abroad and what the state should do about it, 2018). In particular, according to the estimates of O. Poznyak, Head of the Migration Research Department of the Institute of Demography of the National Academy of Sciences of Ukraine, the number of Ukrainian labour migrants reaches 2,3 million people (Poznyak, 2016), Professor of the Kyiv School of Economics H. Vakhitova - 2,5 million (Vakhitova, 2018), the Economic Strategy Centre - 2,6 million people (How many Ukrainians went abroad and what the state should do about it, 2018).

\section{CENSUS OF POPULATION}

Therefore, in our opinion, there is a need for a census to improve the quality of migration data. The last census was conducted in 2001, and every year its data becomes increasingly outdated. Since last population census, the State Statistics Service reports only estimated population figures calculated on the basis of fertility, mortality and (official) migration growth. This affects not only the quality of demographic data, but also indicators such as GDP per capita, for example.

It is also worth considering the use of mirror statistics, in particular registers of countries where most Ukrainians go. The current methodology can be revised to take into account the possibilities that the newly created demographic register and registers of territorial communities can provide. The existing Fiscal Service Registers can provide additional estimates. Also, best practices in the use of 
big data (mobile operators, social networks, etc.) for estimating cross-border movements are already worth adopting (Tishchuk, 2018).

For example, an analysis of Estonian media with reference to data from the country's Ministry of the Internal Affairs revealed that Ukrainians are in the lead among migrants. Among citizens who received short-term work permits for up to 12 months, the share of Ukrainians is $80 \%$. Ukrainians also lead in terms of residence permits obtained in Estonia. However, Estonia is far from being the first country where Ukrainian citizens go to work and live. According to the State Border Guard Service, the most popular country for work and life of Ukrainians is Poland. The most active departure process has been observed in the last three years (Figure 3).

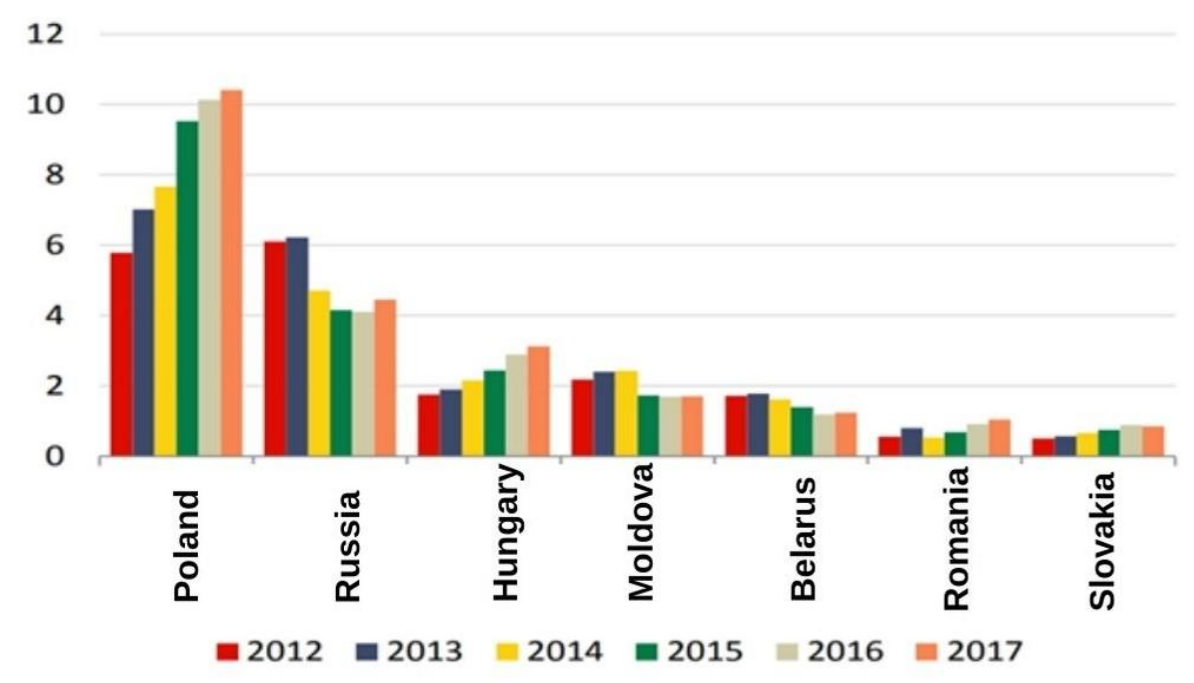

Fig. 3. Departure of Ukrainian citizens to neighboring countries Source: (The State Border Service, 2012-2017)

Poland`s economy continues to grow and wages are 4-6 times higher than in Ukraine, according to the National Bank of Ukraine. Most of all - in agriculture and construction. Moreover, the country is close by and Ukrainians find it easy to adapt there through the close cultural background.

In second place remains Russia, although Ukrainians visit this country less often. Third place went to Hungary.

Orientation to the model of economy with cheap labor force, interpretation of low wages as the main competitive advantage of Ukraine remains for a very long period, and the influence of low wages on motivation of labor migration is constant. But the demand for Ukrainian labor has changed, the conditions of employment abroad have changed (Libanova, 2018).

The demand for Ukrainian migrants is a motivational policy of many developed countries, which is designed specifically to attract additional labor. For example, according to the Polish employment agency Work Service, in 2018 almost 50\% of all companies had problems finding employees, although in 2016 only 35\% stated this. In Germany, the situation is similar. In September 2018, Chancellor A. Merkel said that staff shortages were the "biggest" challenge for the German economy. At the end of 2018, she announced legislative innovations that will continue to ease immigration to meet labor demand, which cannot be done at the expense of the native population (Monitoring the migration situation and developments in migration and border management, 2018).

The growth in demand for labor is due not only to an aging population, but also to growing emigration, which even developed countries suffer from. If in 20052.5 million people emigrated from EC-28 and North America (including within these regions), in 2016 - about 3.5 million. However, if earlier emigration was caused mainly by push factors, in the XXI century factors attracting prevail (Haidutskyi, 2018). Many countries create a large number of motivational programs to annually attract millions of migrants. 
To this we can also add the acquisition of visa-free status, which means, first of all, the possibility to stay in European countries quite legally for three months in a row, looking for an acceptable job. In combination with radical simplification by Poland of the procedure of obtaining so-called work visa for Ukrainians and absence of language barrier (at least in oral communication) this naturally led to the growth of flow of labor migrants from Ukraine to Poland. One should add here a very active encouragement of educational migration of Ukrainian youth by professional educational institutions of most Eastern European (and not only) countries - special programs are opened, grants and scholarships are provided, special preparatory language courses work (Libanova, 2018).

As a result of active labor migration, Ukraine is already experiencing a shortage of labor, especially skilled labor, which hampers the increase in production at many enterprises. The rate of migration from Ukraine is clearly demonstrated by the rapid growth of remittances from individuals to Ukraine in 2015-2018 (Fig. 4).

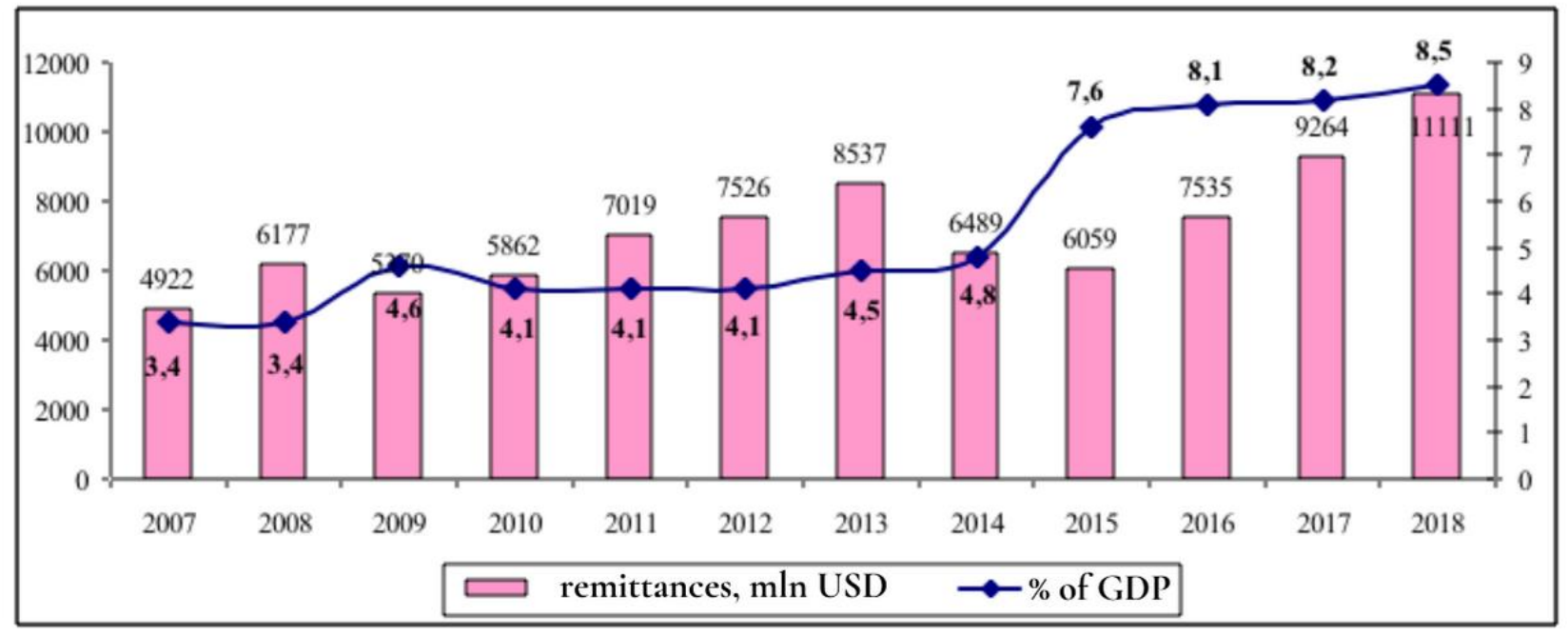

Fig. 4. Private currency remittances to Ukraine in 2007-2018

Source: (Financial Stability Report, 2018)

Migrants` earnings play an important role in improving the well-being of their households and preventing poverty. They are also of significant economic importance, providing an inflow of foreign currency, ensuring the stability of the domestic foreign exchange market, supporting consumption and savings. According to the National Bank of Ukraine (estimated based on data from the State Statistics Committee of Ukraine, the National Bank of Poland, and the Central Bank of Russia), the amount of private money transfers to the country has been steadily increasing (especially since 2015) and in 2018 it has already reached $8.5 \%$ of the country's GDP.

The change in the structure of private remittances may also indicate a change in the geographical structure of Ukrainian migrants. In 2015-2017 alone, remittances from Poland increased by $138.5 \%$, from other EU countries by $23.8 \%$, from the USA and Canada by $33.3 \%$, while, on the contrary, from Russia decreased by $27.8 \%$ (Financial Stability Report, 2018).

However, as stated in the NBU report, in the long run mass labor migration creates high risks. It leads to a decrease in potential GDP and excessive pressure on public finances, because migrant workers avoid paying taxes and social contributions.

Overall, the analysis summarizes the main serious challenges posed by migration processes for Ukraine:

1) increase in the scale of migration abroad, primarily labor migration;

2) increased participation of young people, specialists in labor migration;

3) increased number of migrants working abroad without proper permits and in an unsettled legal situation;

4) transformation of part of temporary labor migration to permanent migration. 
This situation threatens to have negative demographic as well as economic consequences. An eventual shortage of workers may become a brake on the development of the economy, and the outflow of the most active, young and educated individuals may become a brake on the democratic transformations in Ukraine. However, on the other hand, direct acquaintance of the population with the European way of life and values will help accelerate the modernization of the country. The outflow of workers abroad, in addition to creating a human resource shortage, may force businesses to value Ukrainian labor higher and compete for workers by creating more attractive and better-paid jobs.

The International Organization for Migration notes that Ukrainians constitute the largest share of labor migrants with higher education among the countries of Southeast Europe it studied (Migration in Ukraine: facts and figures, 2016). And this is what it sees as the main threat to Ukraine, which is rapidly losing educated and experienced professionals (engineers, doctors, IT specialists, agronomists, and teachers). At the same time, this is also detrimental for the people themselves, because qualified migrant workers subsequently lose their skills because they often engage in "unrelated" activities - one out of three Ukrainian migrants with higher education performs work that does not require such high qualifications (Mostova, 2018).

The Ukrainian labor market is negatively affected by the long-term labor migration of fairly skilled workers, primarily gas and electric welders, medics, construction workers, truck drivers and seamstresses. It is very difficult to find replacements for them, so enterprises are already suffering from a shortage of specialists in their relevant professions.

And the so-called "brain drain", i. e. the outflow of highly qualified scientists, teachers, doctors, actors, etc., is often transformed into emigration and, contributing to the rise of global development, causes obvious irreversible losses to the Ukrainian economy (science, education, medicine, industry, etc.).

\section{FACTORS OF MIGRATION INTENSIFICATION}

The migration process as a whole is defined by causes, conditions and factors. As the analysis has shown, there is no unambiguous definition and distinction of these concepts and approaches in the scientific literature.

L. Rybakovskyi defines the migration factor as a set of conditions and circumstances which, through a special combination and interaction, influence the territorial mobility of the population (Rybakovskyi, 2011).

Many researchers equate causes and factors. Thus, V. Perevedentsev notes in many of his works: in order to find out the factors of migration, one should establish the reasons that force people to move. In another work he explains that the causes of migration phenomena, which, on the one hand, are quite general and profound, and on the other - specific to the migration of the population, can be called factors (Perevedentsev, 2005).

According to $\mathrm{O}$. Khomra, migration is caused by certain reasons; and most relocations (migrations) are mainly related to factors of an economic nature. He further states that the reasons are the migrant's attitude to the conditions (Khomra, 1998). V. Kostakov calls the reasons of migration the availability of jobs, and the factors - a higher standard of living, better natural and climatic conditions, etc (Kostakov, 1995).

The most complete picture of the totality of migration factors is given in the works of $\mathrm{V}$. Perevedentsev. He distinguishes, for example, economic, ethnic, demographic, natural (naturalgeographical), moral, sociological, cultural, social-psychological factors, as well as subjective and objective factors of migration. The objective ones are understood as territorial differences in significant living conditions, the subjective ones are defined as peculiarities of human structure (needs, interests, aspirations, value orientations), which determine differentiation of decisions made in the same conditions by different individuals or groups (Perevedentsev, 2005).

According to Becker's theory of individual choice (Becker, 2003), labour migration results from a number of objective factors, such as: differences in population size and living standards in 
developed countries compared to third countries; reduced administrative and other barriers to migrants due to globalisation processes; the need to cover deficits caused by low birth rates in the labour market of developed countries at the expense of young people from abroad. A significant factor contributing to the outflow of workers from Ukraine and their movement abroad is economic. The desire for adequate wages, good working conditions and a high standard of living and material wellbeing encourages workers to seek higher-paid employment abroad. Skilled workers seek decent rewards for the money and time spent on their education. In addition, academic staff are often forced to change locations because of the need to raise the financial resources to carry out research, or they may be forced to give up academic employment in favour of manufacturing or service activities because of the higher salaries.

Consequently, the main employment sectors for Ukrainian labour migrants are construction (29\%), industrial production (14\%), hospitality industry (11\%), domestic help (10\%) and agriculture $(8 \%)$. The latter three sectors are the most popular in EU countries, while trade and transport are considered the most popular labour activities in CIS countries. At the same time, construction and industrial production are also equally important sectors in both regions (Migration in Ukraine: facts and figures, 2016).

The economic problems of recent years, falling incomes and the security situation have increased "brain drain" from Ukraine. The steady decrease in funding for science - in 2017 it was only $0.45 \%$ of GDP (in 2010 it was $0.75 \%$ of GDP) - has increasingly motivated Ukrainian scientists to leave. According to the State Statistics Service, in 2014 alone, 42 candidates and seven doctors of science moved to other countries. But this figure does not reflect the real state of affairs, as it is difficult to determine the number of scientists who have stopped working in science and emigrated.

Since 2015, no records of emigrant scientists have been kept by the State Statistics Service. Their decline is demonstrated by the rapid rate of reduction of qualified workers in the field of science and technology - since 2010, the number of workers involved in research and development has halved, taking into account candidates and doctors of science (fig. 5).

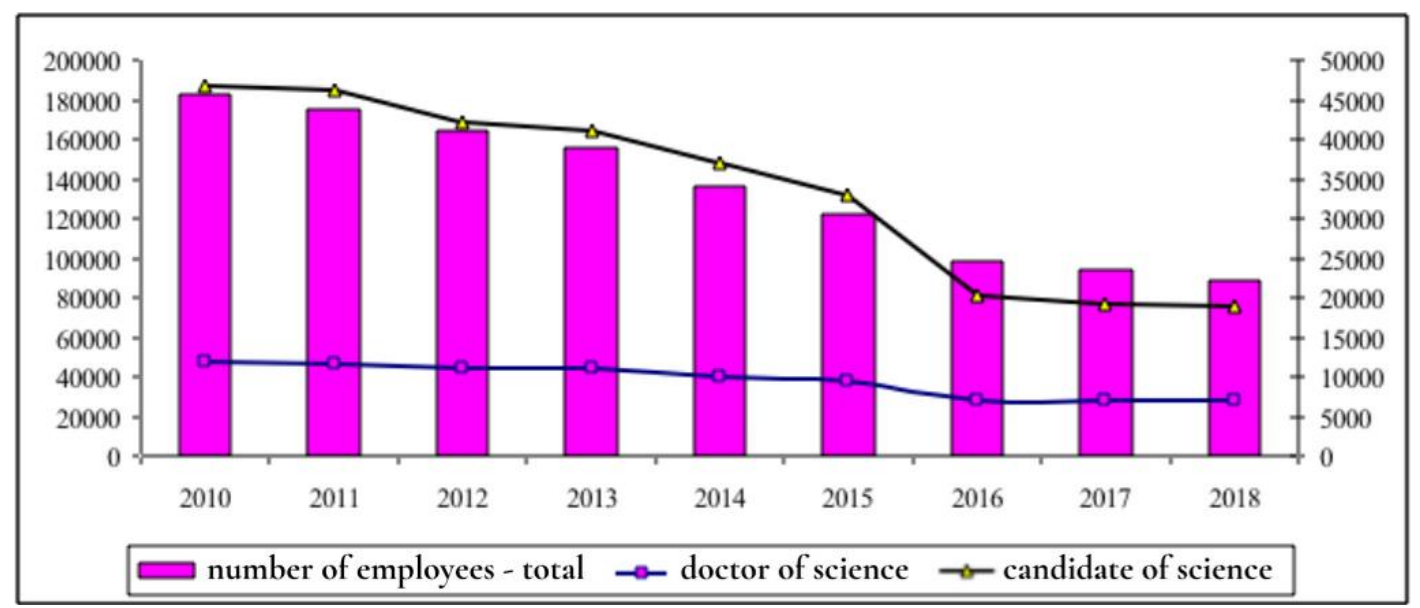

Fig. 5. Dynamics of the number of employees involved in research and development $\mathbf{1 , 2 , 3}$

Notes: ${ }^{1 .}$ - Data for 2010-2015 include permanent and temporary employees (part-time and contractual employees, including academic staff); ${ }^{2}$ - As of 2016, the figures do not include academic staff who have not carried out research and development activities. ${ }^{3}$ - Since 2014, data excludes the temporarily occupied territory of the Autonomous Republic of Crimea, the city of Sevastopol and part of the temporarily occupied territories of Donetsk and Luhansk regions.

Source: (Economic statistics. Science, technologies and innovations, 2017)

Let us elaborate on the main reason Ukrainians migrate. According to surveys by the Kyiv International Institute of Sociology (KIIS), 45\% of respondents are willing to go abroad to earn more money, which is quite predictable. Since the start of the crisis, Ukraine's "absolute poverty rate" has risen rapidly, from 3.3\% in 2014 to 5.8\% in 2015 (The World Bank, 2005-2017). The minimum wage increase, which was a necessity, could not compensate for the depth of the fall. The average wage in Ukraine as of November 2017 was 7,479 UAH, or $€ 213$ at the current exchange rate. A truck or bus 
driver in Poland earns between 2,800 and 4,000 zlotys, or €700-900 per month, and the employer is willing not only to provide him with food and lodging, but also to bear the costs of paperwork.

If we compare the dynamics of GDP per capita and the number of migrants (fig. 6), we can see the obvious consequences of the deteriorating macroeconomic situation in the country, leading to increased migration.

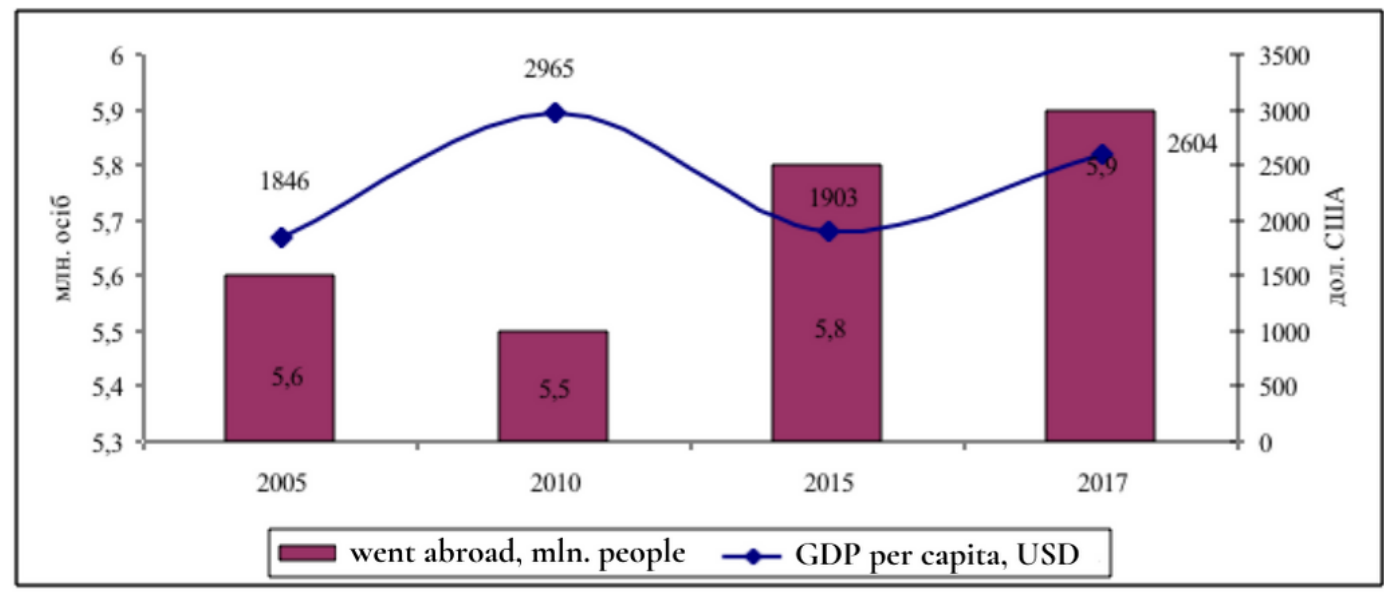

Figure 6. Number of Ukrainian migrants and GDP per capita in Ukraine

Source: (Constructed on the basis of data from the UN, World Bank, 2005-2017).

In addition, the trend of average wages in US dollars fully mirrors the dynamics of GDP per capita, so its low level also forces citizens to go abroad to earn money. The data from KMIS surveys confirms this thesis. The main reasons for possible emigration in December 2016 Ukrainians named the offer of lucrative jobs (28\%) and the armed conflict in the east of the country, which certainly influenced the growth of migration and further influenced people's perceptions (27\%). Next come economic problems in the country (19\%) and family circumstances (18\%). At the bottom of the list of reasons for possible emigration are lack of conditions for self-realization (9\%) and political instability (7\%). One third of Ukrainians (29\%) stated that no circumstances would make them leave the country for good (Promising Ukrainians are increasingly going abroad: statistics, 2017). Thus, the main reason is the difference in wages. For example, an electrical engineer in Ukraine earns between 6,000 and 12,000 UAH while in Germany they earn 60,000-90,000 UAH (The State Statistics Service of Ukraine, 2017). In addition, there is an imbalance between supply and demand on the Ukrainian labour market (Gots, 2017).

Accordingly, the analysis of the current state of external migration processes in Ukraine allows us to summarize the factors (table 2) that cause and hinder migration growth.

Table 2. Factors influencing migration processes in Ukraine

\begin{tabular}{|c|c|}
\hline Emigration-stimulating factors & Immigration-stimulating factors \\
\hline \multicolumn{2}{|l|}{ Political } \\
\hline Lack of effective state migration policy instruments in the state & Clear ( lenient ) migration policy \\
\hline Low level of democracy & Advanced democracy \\
\hline Political instability & Stability of the political system \\
\hline High levels of corruption & Absence of corruption \\
\hline Threats to national security (military conflicts) & Peace and security \\
\hline \multicolumn{2}{|l|}{ Economical } \\
\hline Low wages & High wages \\
\hline Low standard of living & A high standard of living \\
\hline
\end{tabular}




\begin{tabular}{|c|c|}
\hline $\begin{array}{l}\text { Disproportions in regional economic development, economic } \\
\text { instability }\end{array}$ & Sustainable economic development \\
\hline $\begin{array}{l}\text { High levels of unemployment, an imbalance between supply } \\
\text { and demand in the labour market }\end{array}$ & High employment rates \\
\hline \multicolumn{2}{|l|}{ Social } \\
\hline An outdated education system & High quality of education \\
\hline An imperfect health care system & A high-quality health care system \\
\hline Lack of opportunities for professional development & Opportunities for professional self-fulfilment \\
\hline \multicolumn{2}{|l|}{ Ecological } \\
\hline $\begin{array}{l}\text { Threatening environmental situation (environmental } \\
\text { pollution) }\end{array}$ & Safe ecology \\
\hline Poor quality of drinking water and food & $\begin{array}{l}\text { High-quality drinking water and environmentally } \\
\text { friendly food }\end{array}$ \\
\hline \multicolumn{2}{|l|}{ Globalising } \\
\hline \multicolumn{2}{|l|}{ Increased relocation opportunities (visa facilitation) } \\
\hline \multicolumn{2}{|l|}{ High level of development of communication and informatisation } \\
\hline Presence of a national cell (diaspora) in the host countries & \\
\hline
\end{tabular}

Considering the significant deterioration of employment opportunities and incomes in Ukraine, the intensity of external labour migration can hardly be expected to decrease in the near future. Under these conditions the Ukrainian state needs to endeavour to maximise the use of labour migration for the development of society and to minimise its possible negative consequences. In the coming years the main objective of the state is to provide support for labour migrants' ties with Ukraine and to encourage remittances. Policies towards new labour migrants (who started travelling abroad after the 2014-2015 crisis) must be aimed at preventing circular labour migration from turning into emigration, which leads to irretrievable loss of population. In this context, an important activity is the elaboration of a policy document that would contain a list of measures for the Ukrainian state to deal with each category of labour migrants from Ukraine, depending on their specificities.

\section{CONCLUSIONS}

1. The determining factors influencing the external migration of Ukrainian citizens are economic: low wages, low standard of living, imbalance of regional economic development, economic instability, high unemployment, imbalance between supply and demand on the labour market.

2. At present it is extremely difficult to estimate the scale of external migration of Ukrainians; official statistics do not accurately reflect the number of external migrants, which shows a positive migration balance, in contrast to data from other sources. Such discrepancies in migration estimates are conditioned both by different definitions of "migrant" and by different methods of data collection.

3. The main challenges conditioned by migration processes for Ukraine are, firstly, the increase in migration abroad, primarily labour migration; secondly, intensified participation of young people, specialists in labour migration; and thirdly, the transformation of some temporary labour migration into permanent migration. A particularly painful problem for Ukraine is the emigration of skilled workers.

4. In addition, it has been established that, in addition to social factors, the driving factors for emigration of the Ukrainian population are:

- political factors (lack of effective state instruments of migration policy in the state, low level of democracy, political instability, high level of corruption, military conflicts); 
- social factors (outdated education system, imperfect healthcare system, lack of opportunities for professional development); food);

- environmental factors (threatening environmental situation, low quality of drinking water and

- globalisation factors (increased opportunities for movement, high level of communication and informatisation, presence of a national cell (diaspora) in the host countries).

Under the conditions of deteriorating employment opportunities and incomes in Ukraine, external labour migration is likely to increase further. Therefore, state policy towards new labour migrants must be aimed at preventing circular labour migration from turning into emigration, which leads to irretrievable loss of population.

\section{REFERENCES}

Migration in Ukraine: facts and figures. IOM Mission in Ukraine. https://www.iom.org.ua/sites/default/files/ff_eng_10_10_press.pdf

United Nations, Department of Economic and Social Affairs, Population Division (2017). Trends in International Migrant Stock: The 2017 Revision. (United Nations database, POP/DB/MIG/Stock/Rev.2017)

Becker, G.S. (2003). Human Behaviour: An Economic Approach. Selected works on economic theory: translated from English. Ed. by R.I. Kapeliushnikov. MOSCOW: GU HIGHER SCHOOL OF ECONOMICS. 672 p.

Vakhitova, G. (2018). "Every tenth adult Ukrainian works abroad. This is a large figure, but not catastrophic".

LB.ua. https://ukr.lb.ua/economics/2018/04/26/396321_ganna_vahitova_kozhen_desyatiy.html

Haidutskyi, A. (2018). What should Ukraine do in the era of high demand for Ukrainians. Dzerkalo tyzhnia. № 1211. https://dt.ua/internal/borotba-za-migrantiv-ukrayini-prigotuvatisya289703_.html

Gots, A. (2017). Market of educational services: problems of functioning in Ukraine. Economy and education: modern tendencies. Opole. P. 128-133

Economic statistics. Science, technologies and innovations. The State Statistics Service of Ukraine. http://www.ukrstat.gov.ua/operativ/operativ2017/ni/kpno_kp/kpno_kp_u.html

Financial Stability Report. (2018). National Bank of Ukraine. https://bank.gov.ua/doccatalog/document?id=71475860

Catastrophic situation: a million citizens leave Ukraine every year. (2018). Ukrainian news. https://ukranews.com/ua/news/581748-katastrofichna-sytuaciya-shhoroku-ukrainu-pokydayemilyon-gromadyan

Kvasha, O. S. (2018). Labour market in Ukraine: analysis of the current state and prospects for development. Global and national problems of the economy. Edit. 22. http://globalnational.in.ua/issue-22-2018/30-vipusk-22-kviten-2018-r/4051-kvasha-o-s-rinok-pratsi-v-ukrajinianaliz-suchasnogo-stanu-ta-perspektivi-rozvitku

Kolot, A. M., Gerasymenko, O. O (2017). Global social inequality of income: nature, trends, consequences. Social and labour relations: theory and practice: col. of pap. Min. of Education and Science of Ukraine; Vadym Hetman National Economic University of Kyiv; Institute of Social and Labour Relations - Kyiv: KNEU. No2. P. 8-47

Kostakov, V. (1995). Problems of labor market formation. Economics and Mathematical Methods. № 5. P. 39.

Libanova, E. M. (2018). External labor migrations of Ukrainians: scale, causes, consequences. Demography and social economy. № 2 (33). P. 10-26. https://dse.org.ua/arhcive/33/1.pdf

Malynovska, O. A. (2018). Labour migration of Ukrainian citizens abroad: challenges and ways of response. National Institute for Strategic Studies. http://old2.niss.gov.ua/content/articles/files/Malynovska-d28e1.pdf 
Migration in Ukraine: facts and figures. (2016). International organization for migration. The Un Migration Agency. https://www.iom.org.ua.

Ministry of Social Policy named the exact number of Ukrainian labor migrants. (2018). Interfax-Ukraine. Information agency. https://ua.interfax.com.ua/news/economic/556270.html

Monitoring the migration situation and developments in migration and border management. (2018). Support for migration and asylum management in Ukraine. https://dmsu.gov.ua/assets/files/migprocess/zvit_vypusk_28.pdf

Mostova, Yu. (2018). Why Ukrainians leave their country. Dzerkalo tyzhnya. https://dt.ua/internal/krovotecha-chomu-ukrayinci-pokidayut-svoyu-krayinu-267394_.html

The State Statistics Service of Ukraine. Official website. http://www.ukrstat.org.ua

Perevedentsev, V. I. (2005). Population Migration in the CIS Experience of Forecasting. Polis. $167 \mathrm{p}$.

Libanova, E., Tsymbal, O., Yarosh, O. \& Lisogor, L. (2016). Ukraine's Youth Labour Market Transition: Results of the International "School-to-work Transition Surveys" in Ukraine in 2013 and 2015. International Labour Office-Geneva, $\quad$ ILO. $\quad 123 \quad$ p. http://www.idss.org.ua/monografii/2016_Zvit_rynok_pratsi.pd

Promising Ukrainians are increasingly going abroad: statistics. SvitUa. http://svitua.com.ua/news/201701/2236-perspektyvni-ukrayinci-dedali-chastishe-vyyizhdzhayut

Poznyak, O. V. (2016). Assessment of the consequences of external labour migration in Ukraine. Demography and social economy. № $2 . \quad$ P. 169-182. http://nbuv.gov.ua/UJRN/dse_2016_2_15.

Romanyuk, M. D. (2016). Foreign labour migration and re-emigration in the context of national security of Ukraine. Regional economy. № 4. P. 22-30. http://nbuv.gov.ua/UJRN/regek_2016_4_5

Rybakovskyi, L. L. (2011). Stages of the migration process. The Min. of Federation, Nationalities and Migration Policy. Federation. 160 p.

How many Ukrainians went abroad and what the state should do about it. Analytical note. Economic Strategy Center. https://ces.org.ua/wp-content/uploads/2018/04/Migration-note.pdf

Smaliychuk, G. V. (2017). Migration installations of modern youth in the labor market of Ukraine. Social and labor relations: theory and practice: Ed. Science Ave. Social and Labor Sphere: Current State, Problems and Strategic Directions of Development: Theses of the participants of the International Scientific and Practical Conference. Internet-conference, 14-16. Ministry of Education and Science of Ukraine, Vadym Hetman National Economic University of Kyiv. KNEU. P. 179-181. http://ir.kneu.edu.ua/bitstream/2010/23003/1/179-181.pdf

Sadova, U. (2018). Structural shifts in Ukraine's GDP under conditions of growing labor migration: national and regional aspects. National Academy of Sciences of Ukraine, M. I. Dolishnyi State Inst. of Regional Researchers. - Lviv: M. I. Dolishnyi State Inst. of Regional Researchers, NAS of Ukraine. $54 \mathrm{p}$.

Tishchuk, T. (2018). Big migration: why no one in Ukraine knows how many of our citizens have gone abroad. Vox Ukraine. https://voxukraine.org/uk/velika-migratsiya-chomu-nihto-vukrayini-ne-znaye-skilki-nashih-gromadyan-viyihalo-za-kordon/

Khomra, O. (1998). Structure and directions of migration flows of the population of Ukraine (final scientific report on the project). Kyiv.

Athukorala, P.-C. (2006). International labour migration in East Asia: Trends, patterns and policy issues. Asian-Pacific Economic Literature. Scopus. https://www.scopus.com/record/display.uri?eid=2-s2.0-33645465609\&origin=resultslist\&sort=plff\&cite=2-s2.00036619056\&src=s\&imp=t\&sid=25d527df2f88d661e587e9e82f84acdb\&sot=cite\&sdt=a\&sl=0\&rel pos $=6 \&$ citeCnt $=28 \&$ searchTerm $=$

Belanger, D., Ueno K., Hong, K.T. \& Ochiai, E. (2011). From foreign trainees to unauthorized workers: Vietnamese migrant workers in Japan. Asian and Pacific Migration Journal. Scopus. https://www.scopus.com/record/display.uri?eid=2-s2.0-79957527978\&origin=resultslist\&sort=plff\&cite=2-s2.0- 
0036619056\&src=s\&imp=t\&sid=25d527df2f88d661e587e9e82f84acdb\&sot=cite \&sdt=a\&sl=0\&rel pos $=3 \&$ citeCnt $=9 \&$ searchTerm $=$

Midori, O. (2018). Updating the Immigration Debate. Nippon.com - Your Doorway to Japan. Updating the Immigration Debate | Nippon.com

Fee L.K., Rahman, M.M. (2006). International labour recruitment: Channelling bangladeshi labour to east and South-East Asia. Asia-Pacific Population Journal. Scopus. https://www.scopus.com/record/display.uri?eid=2-s2.0-41349123421\&origin=resultslist\&sort=plff\&cite $=2-\mathrm{s} 2.0$

0036619056\&src=s\&imp=t\&sid=25d527df2f88d661e587e9e82f84acdb\&sot=cite \&sdt=a\&sl=0\&rel pos $=7 \&$ citeCnt $=12 \&$ search Term $=$

Komine, A. (2018). A Closed Immigration Country: Revisiting Japan as a Negative Case. International Migration. Scopus. https://www.scopus.com/record/display.uri?eid=2-s2.0$85043479563 \&$ origin=resultslist \&sort=plf-f\&cite=2-s2.0-

$0036619056 \& \mathrm{src}=\mathrm{s} \& \mathrm{imp}=\mathrm{t} \& \mathrm{sid}=25 \mathrm{~d} 527 \mathrm{df} 2 \mathrm{f} 88 \mathrm{~d} 661 \mathrm{e} 587 \mathrm{e} 9 \mathrm{e} 82 \mathrm{f} 84 \mathrm{acdb} \& \mathrm{sot}=\mathrm{cite} \& \mathrm{sdt}=\mathrm{a} \& \mathrm{sl}=0 \& \mathrm{rel}$ pos $=0 \&$ citeCnt $=6 \&$ searchTerm $=$

Yasushi, I. (2012). What Role Do Low-Skilled Migrants Play in the Japanese Labor Markets. Kwansei gakuin university, School of economics. https://www.researchgate.net/profile/YasushiIguchi

Hosogaya, N. (2020). Migrant workers in Japan: socio-economic conditions and policy. Emerald insight - Discover Journals, Books \& Case Studies. https://www.emerald.com/insight/content/doi/10.1108/AEDS-02-2019-

0032/full/html?skipTracking=true

Oishi, N. (2012). The Limits of Immigration Policies: The Challenges of Highly Skilled Migration in Japan. American Behavioral Scientist.

Deborah, J.M. (2020). Japan's Labor Migration Reforms: Breaking with the Past. Migration policy institute.

Ruhs, M. (2013) The price of rights: Regulating international labor migration. Princeton University Press.

Ford, M., Kawashima, K. (2013). Temporary Labour Migration and Care Work: The Japanese Experience. Journal of Industrial Relations. https://core.ac.uk/download/pdf/212688226.pdf

Migrants and GDP per capita. The world Bank. (2005-2017). https://www.worldbank.org/en/home 


\title{
ESTIMATION OF TENDENCIES OF TRANSFORMING THE ENERGY SECTORS OF WORLD, EUROPEAN UNION AND UKRAINE IN THE PERSPECTIVE TO 2050 WITH USING THE RENEWABLE ENERGY SOURCES IN THE CONCEPT OF SUSTAINABLE DEVELOPMENT
}

\author{
Olga Ostapenko ${ }^{1}$ \\ ${ }^{1}$ Candidate of Engineering Sciences, Ph.D, Associate Professor, Associate Professor of the Department of Heat Power \\ Engineering, Vinnytsia National Technical University \\ Vinnytsia, Ukraine \\ ORCID ID : 0000-0001-9682-9419
}

\begin{abstract}
The study presents an approach aimed at assessing trends in the reform of the energy sector of the world, the European Union and Ukraine in the future until 2050, using renewable energy sources in the concept of Sustainable Development. Our research is aimed at: analysing the energy sector of the world, the European Union and Ukraine and identifying the benefits of using renewable energy sources in the concept of Sustainable Development, assessment of prospects for the application of innovative technologies based on renewable energy sources in the concept of Sustainable Development. A number of criteria for energy, economic and environmental efficiency of innovative technologies for the use of renewable energy sources are analysed in order to conduct a comprehensive assessment of the effectiveness of energy and resource-saving, environmentally friendly and cost-effective innovative technologies in the concept of Sustainable Development. This approach allows providing a reasonable definition of prospects for the use of energy and resource-saving, environmentally friendly and cost-effective innovative technologies for the use of renewable energy sources in the concept of sustainable development to increase energy, economic efficiency and environmental security of Ukraine's energy sector.
\end{abstract}

\section{INTRODUCTION}

The processes of globalization of world economic relations are characterized by positive effects, as well as significant risks due to the emergence of various conflicts in various spheres of human activity: economic, political, financial and social. Contradictions and conflicts that arise between states and economic actors increase the vulnerability of their security systems, reduce competitiveness and affect the level of economic prosperity. The role of the fuel and energy complex in ensuring the economic security of the country is determined by the priority of this industry in the economic system.

Energy security plays a key role in the state's national security system. Natural resource factors (mainly the availability and efficiency of energy resources) play a key role in the formation of a comprehensive security system for industrial and post-industrial economies. This problem is also relevant for the Ukrainian economy, which remains one of the most energy-intensive. Issues of national security have become particularly acute in recent years, when Ukraine has faced serious geopolitical challenges and serious socio-economic shocks.

The degree of stability of the energy complex is characterized by the term "energy security", which defines the state of protection of the interests of economic entities associated with ensuring the required level of consumption of various types of energy. Energy plays an important role in the economic and social stability of the country, significantly affects living standards and economic security. Therefore, the stability of the country's economic system in many cases is determined by the level of stability of energy companies.

Integration of the United Energy System (UES) of Ukraine into the European Network of Transmission System Operators for Electricity (ENTSO-E) is one of the strategic goals of national energy company «Ukrenergo», as it will increase the reliability of the energy systems, ensure efficient use of energy resources and increase exchange capacity. This is an important component of Ukraine's energy security. After all, the synchronous operation of Ukraine's energy system with the ENTSO-E 
energy association will increase the reliability and sustainability of Ukraine's UES, expand electricity exchange opportunities between neighboring countries, increase competition in the domestic market and create opportunities for the European energy market. The integration of the United Energy System of Ukraine into the pan-European energy system ENTSO-E is provided for in the Association Agreement between Ukraine and the European Union (EU).

The concept of Sustainable Development involves a combination of economic, social and environmental trends in the modern world. The concept of Sustainable Development provides for the reduction of consumption of scarce natural non-renewable resources while increasing the use of nontraditional renewable energy resources through the widespread use of environmentally friendly energy- and resource-saving production technologies at all stages of the life cycle.

The concept of sustainable development, according to (Arkhypova, et al, 2021; Brych and Fedirko, 2018; Emas, 2015; Koval, et al, 2019; Mandryk, et al, 2017; Ostapenko, 2020), aims to maintain economic advancement and progress while protecting the long-term value of the environment. The concept of sustainable development implies the optimal use of limited resources and the use of environmentally friendly nature-, energy- and material-saving technologies at all stages of the life cycle with the production of environmentally acceptable products (Koval, et al, 2017, 2018, 2019).

As it is noted in (Ostapenko, Savina, et al, 2020), the concept of Sustainable Development is determinates the 17 Sustainable Development Goals (SDGs), that defined the tendencies of development of sustainable energy and fuel and energy complex of Ukraine in the direction of European integration, ensuring reduction of greenhouse gas emissions and increasing the use of nontraditional and renewable energy sources with the application of energy- and resource-saving, environmentally safe and cost-effective innovative technologies.

\section{ANALYSIS OF ENERGY SECTORS OF WORLD AND EUROPEAN UNION AND DETERMINATION OF ADVANTAGES OF APPLICATION OF RENEWABLE ENERGY SOURCES FOR UKRAINE IN THE CONCEPT OF SUSTAINABLE DEVELOPMENT}

The International Energy Agency (IEA) has prepared an analytical work "For ecast of world energy development for the period up to 2035", which states that in the period $2010-2035$ there will be an increase in world energy consumption by 35\%: the smallest increase in consumption will be use of coal (13\%), the largest - for the use of renewable energy sources (RES) (87\%). It is noted that fossil energy resources will play a key role in the further development of world energy, however, their share in primary energy consumption in 2035 will be reduced to $75 \%$ (today - 81\%) ("Foreign experience in improving energy efficiency and introducing new technologies for electricity generation", 2021). It should be noted that the long-term forecast of the IEA and other international organizations provides for an annual reduction in energy intensity of gross domestic product (GDP), which is planned to increase energy efficiency in all sectors of the economy, especially the most energy-intensive - industry and energy.

At the same time, in Ukraine the level of fuel and energy expenditures on GDP production, especially in industry and energy, is declining at a relatively slow pace and as of the end of 2020 significantly exceeded the average level both in the EU and in the world as a whole. This indicates a relatively low level of implementation of energy efficient technologies in the sectors of economy and energy in Ukraine. Electricity is the fastest growing sector of energy consumption (56\% growth by 2035). In developed countries, almost all the increase is due to the generation and consumption of electricity and heat. In developing countries, the main increase in demand - in electricity and industry. In the transport sector, in addition to oil, the use of other fuels is increasing, but their share will not exceed $12,5 \%$ by the end of the forecast period.

According to the IEA, world consumption of renewable energy sources (RES) by 2040 will reach almost 3 billion tons of oil equivalent, of which 2,7 billion tons of oil equivalent, including 0,5 billion tons, can be directed to electricity and heat production oil equivalent of hydropower. 
Based on the publication ("Main indicators of the fuel and energy complex of Ukraine for 2020", 2021), the structure of electricity generation in the United Energy System of Ukraine in 2020 from power plants of different sources of energy is determined; the results are shown in Tables $1-3$.

Table 1. Structure of electricity production in the United Energy System of Ukraine in 2020 from power plants of different sources of energy

\begin{tabular}{|l|c|}
\hline \multicolumn{1}{|c|}{$\begin{array}{c}\text { Source of primary energy for electricity } \\
\text { production in the United Energy System of } \\
\text { Ukraine }\end{array}$} & $\begin{array}{c}\text { Share of electricity production in the } \\
\text { United Energy System of Ukraine, \% }\end{array}$ \\
\hline Nuclear fuel & 29,31 \\
\hline Coal & 19,27 \\
\hline Natural gas & 15,04 \\
\hline Energy of waves and tides & 9,52 \\
\hline Sale of balances & 7,40 \\
\hline Solar energy & 6,64 \\
\hline Wind energy & 4,51 \\
\hline Sales on the market "day ahead" / intraday market & 3,13 \\
\hline Imports & 2,71 \\
\hline Other fuels / energy & 1,08 \\
\hline Biogas & 0,54 \\
\hline Biomass & 0,39 \\
\hline Information not provided by participants & 0,35 \\
\hline Oil fuel & 0,06 \\
\hline Industrial gas & 0,05 \\
\hline Geothermal energy & 0,00 \\
\hline
\end{tabular}

Source: "Main indicators of the fuel and energy complex of Ukraine for 2020", 2021).

In Table 3 are indicated: HPP - hydro power plants, small HPP - small hydro power plants, mini HPP - mini hydro power plants, micro HPP - micro hydro power plants.

Table 2. Structure of electricity generation in the United Energy System of Ukraine in 2020 from different sources of energy

\begin{tabular}{|l|c|}
\hline \multicolumn{1}{|c|}{$\begin{array}{c}\text { Source of primary energy for electricity } \\
\text { production in the United Energy System of } \\
\text { Ukraine }\end{array}$} & Share of costs per 1 kWh, \% \\
\hline Coal & 19,27 \\
\hline Natural gas & 15,04 \\
\hline Nuclear fuel & 29,31 \\
\hline Natural gas & 15,04 \\
\hline Hydropower (large energy facilities) & 9,52 \\
\hline Renewable energy sources & 13,62 \\
\hline Other sources of energy & 13,24 \\
\hline
\end{tabular}

Source: "Main indicators of the fuel and energy complex of Ukraine for 2020", 2021).

Table 3. Structure of electricity generation in the United Energy System of Ukraine in 2020 from HPP with using hydroenergy, tnergy of waves and tides

\begin{tabular}{|l|c|}
\hline $\begin{array}{c}\text { Type of power plant for electricity production in } \\
\text { the United Energy System of Ukraine }\end{array}$ & $\begin{array}{c}\text { Share of electricity production in the } \\
\text { United Energy System of Ukraine, \% }\end{array}$ \\
\hline $\begin{array}{l}\text { HPP with a capacity of more than } \\
10 \mathrm{MW}\end{array}$ & 9,25 \\
\hline Small HPP & 0,11 \\
\hline Mini HPP & 0,14 \\
\hline Micro HPP & 0,02 \\
\hline
\end{tabular}

Source: "Main indicators of the fuel and energy complex of Ukraine for 2020", 2021). 
It should be noted, that the long-term forecast of the IEA and other international organizations takes into account the annual decline in energy intensity of gross domestic product by increasing energy efficiency in all sectors of the economy, especially more energy-intensive - in industry and energetics ("Foreign experience in improving energy efficiency and introducing new technologies for electricity generation", 2021).

In Fig. 1 (from the investigation (Ostapenko, Savina, et al, 2020)) shows a comparison of gross inland energy consumption by fuel (in\%) for $28 \mathrm{EU}$ countries and Ukraine.

\section{Gross inland energy consumption by fuel, $2017(\%)$}

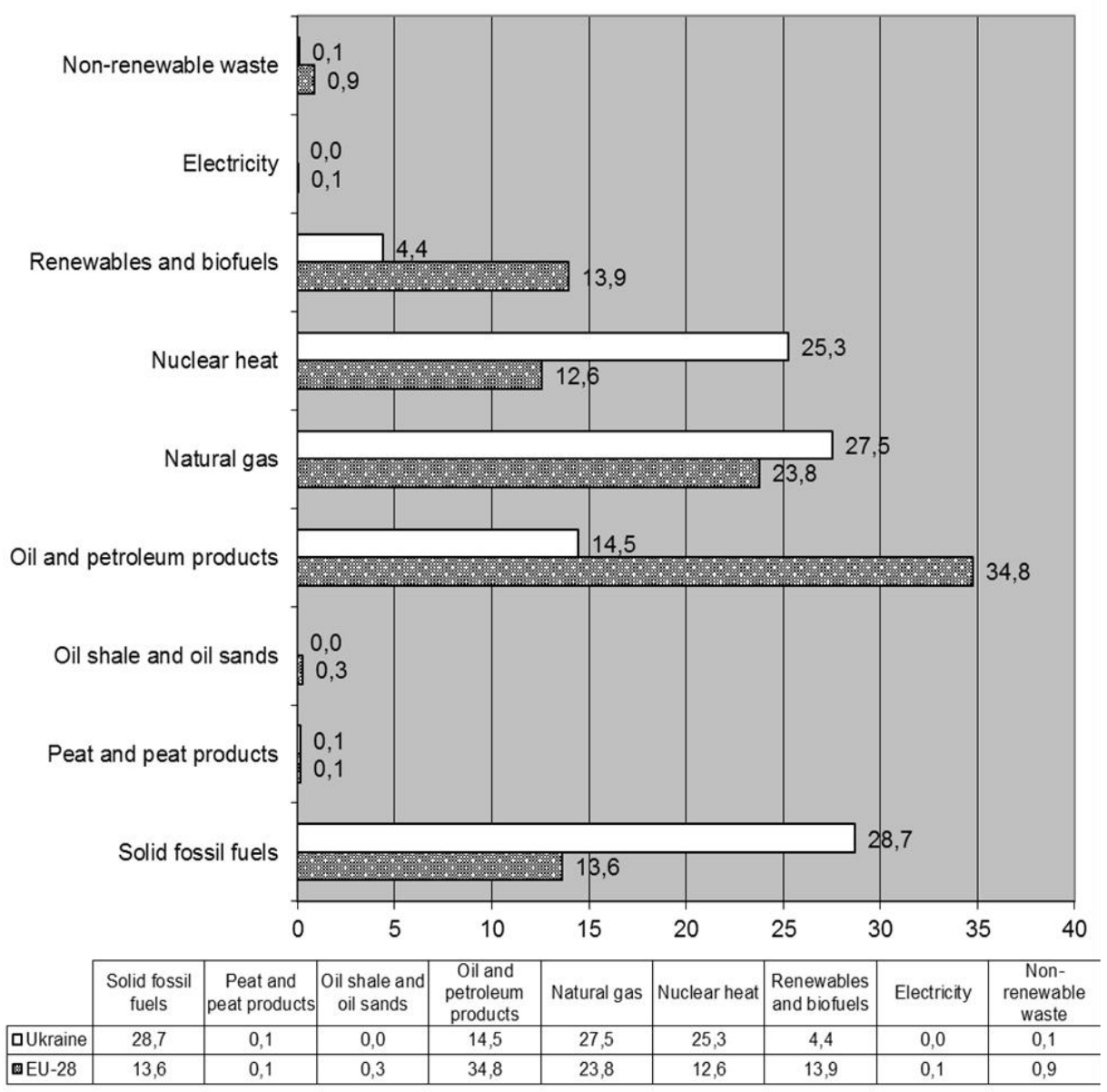

口Ukraine $\bullet \mathrm{EU}-28$

Fig. 1. Comparison of gross inland energy consumption by fuel (in \%) for $28 \mathrm{EU}$ countries (EU-28) and Ukraine

Source: author's research results from (Ostapenko, Savina, et al, 2020)

From fig. 1 (Ostapenko, Savina, et al, 2020) shows that in Ukraine, the percentage of usage of renewable energy and biofuels is $3 . .4$ times lower than in the EU. This indicates the need to increase the share of non-traditional and renewable energy sources in the fuel and energy sector and in the energy sector of Ukraine.

As it is noted in (Ostapenko, 2020) sustainable development of society is possible only in the conditions of energy saving, that is, the development of systems that use energy more efficiently, provide the same or even higher level of transport services, lighting, heating, etc. with less energy consumption. The use of fossil fuels and nuclear energy is contrary to the principle of sustainable 
development, since these resources are non-renewable, and their use pollutes the environment. Moving towards a sustainable society requires a slow elimination of dependence on fossil fuels. Therefore, the way to overcome the current energy crisis is to switch to the use of alternative (nontraditional) energy sources, in particular, the introduction of heat pump installations. Advantages of application of heat pump installations for the conditions of Ukraine are determined and substantiated on the basis of the results of research, published in a number of national and foreign publications (Ostapenko, 2015, 2016, 2017, 2018, 2019, 2020; Ostapenko, Savina, et al, 2020; Ostapenko, Bakum and Yuschishina, 2013; Ostapenko, Leshchenko and Tikhonenko, 2015; Ostapenko and Portnov, 2018; Ostapenko and Shevchenko, 2011; Ostapenko, Valigura and Kovalenko, 2013), as it is noted in (Ostapenko, 2020).

A number of investigations in recent years were devoted to the studying of efficiency of application of innovative resource-saving technologies in the world and Ukraine (Arkhypova, et al, 2021; Koval, et al, 2019; Ostapenko, 2019, 2020; Ostapenko, Savina, et al, 2020).

Our research (Ostapenko, Savina, et al, 2020) is based on the "Tracking SDG7" - resource, which uses the databases of the International Renewable Energy Agency (IRENA), the International Energy Agency (IEA), the World Bank, the United Nations Statistics Division (UNSD) and others ("Tracking SDG7", "Rise", "Esmap"). We also used statistics from Eurostat and World Bank resources ("Eurostat", "DataBank. WorldBank").

The paper (Ostapenko, Savina, et al, 2020) considers the prospects for the application of innovative resource-saving technologies in the concepts of green logistics and sustainable development. Assessment of the perspectives of application of innovative resource-saving technologies in Ukraine was carried out with taking into consideration the main goals of sustainable development, tendencies of development of sustainable energy and fuel and energy complex of Ukraine in the direction of European integration, ensuring reduction of greenhouse gas emissions and increasing the use of non-traditional and renewable energy sources. The study illustrates the application of principles and objectives of the concept of green logistics in order to increase the level of energy-economic efficiency of the energy sector of Ukraine with the application of energy- and resource-saving, environmentally safe and cost-effective innovative technologies.

Presented research is also based on the "Tracking SDG7" - resource, which uses the databases of the International Renewable Energy Agency (IRENA), the International Energy Agency (IEA), the World Bank, the United Nations Statistics Division (UNSD) and others ("Tracking SDG7", "Rise", "Esmap"). We also used statistics from Eurostat and World Bank resources ("Eurostat", "DataBank. WorldBank").

The scientific results, presented in our study, are based on data from the International Renewable Energy Agency (IRENA) database ("IRENA", 2021).

The International Renewable Energy Agency (IRENA) is an intergovernmental organization that supports countries in their transition to a sustainable energy future, and serves as the principal platform for international cooperation, a center of excellence, and a repository of policy, technology, resource and financial knowledge on renewable energy. IRENA promotes the widespread adoption and sustainable use of all forms of renewable energy, including bioenergy, geothermal, hydropower, ocean, solar and wind energy in the pursuit of sustainable development, energy access, energy security and low-carbon economic growth and prosperity. The «REmap 2030», developed by IRENA, is a roadmap to double renewable energy use worldwide by 2030 ("IRENA", 2021).

In Fig. 2 shows a structure of supply of electricity in European Union (EU), January 2019 to January 2020 (in GWh). 


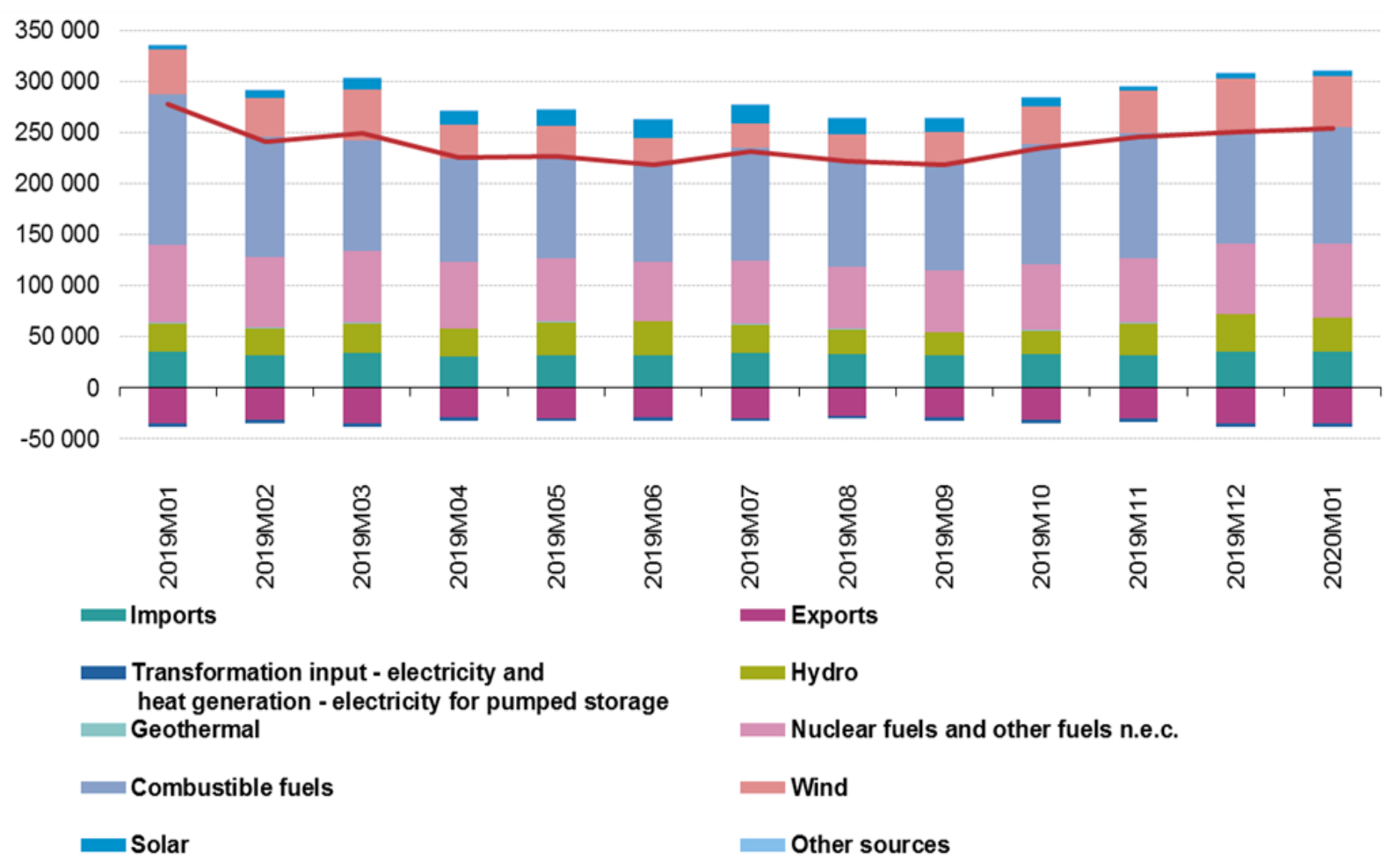

Fig. 2. Structure of supply of electricity in European Union (EU), January 2019 to January 2020 (in GWh)

(Source: Eurostat)

The «Global Renewable Energy Outlook: Transforming Energy by 2050 (April 2020)», developed by the International Renewable Energy Agency (IRENA), shows the path to create a sustainable future energy system. This flagship report highlights climate-safe investment options until 2050, the policy framework needed for the transition and the challenges faced by different regions.

The «Global Renewable Energy Outlook: Transforming Energy by 2050 (April 2020)», shows the outlines the investments and technologies needed to decarbonize the energy system under the Paris Agreement. It is also exploring deeper decarburization options for the heaviest sectors, with the aim of eventually reducing carbon dioxide $\left(\mathrm{CO}_{2}\right)$ emissions to zero ("IRENA", 2021).

In Fig. 3 shows a structute of generation (net) of electricity by type of fuel in EU, January 2019 to January 2020 (in \% based on GWh). 


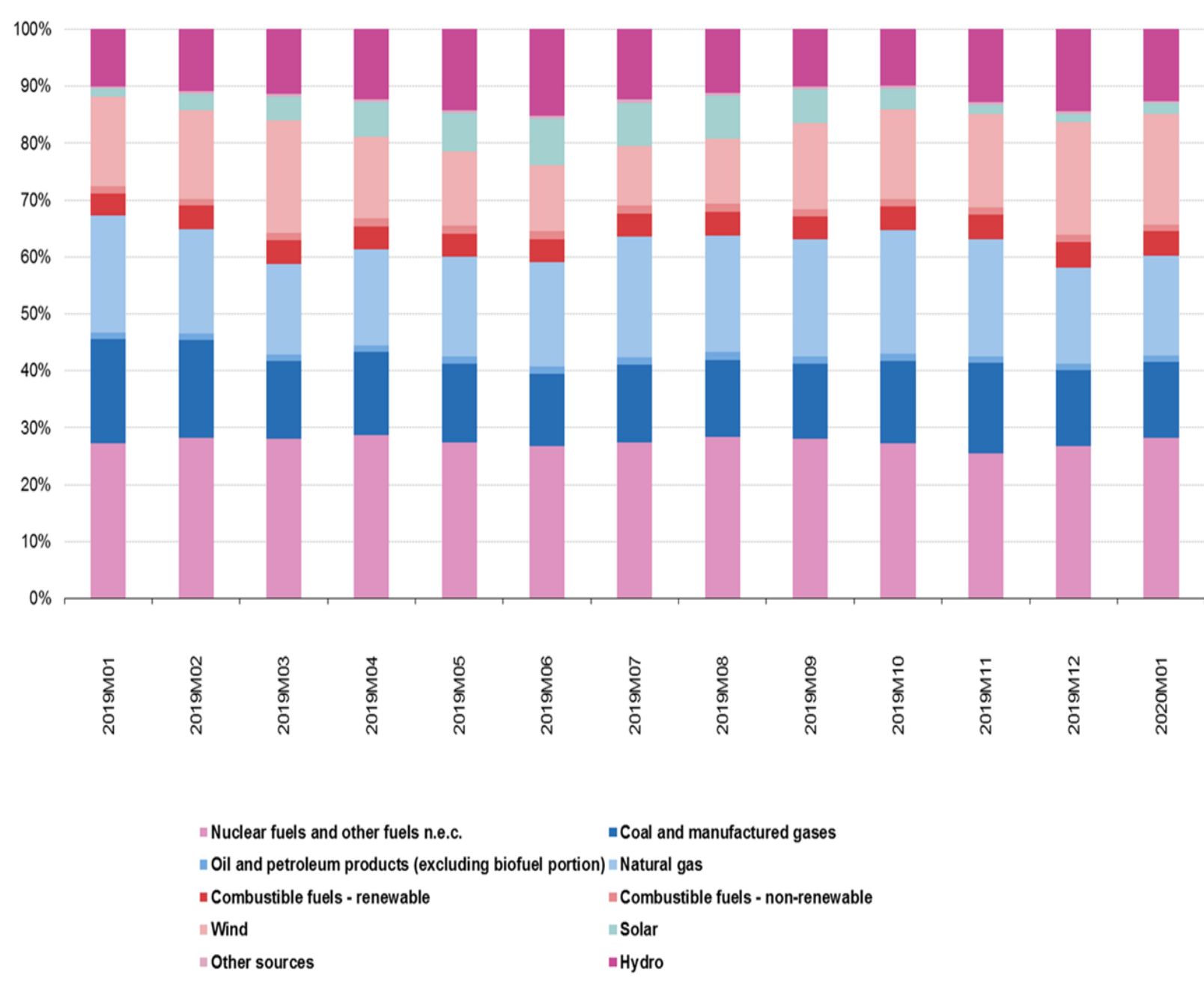

Fig. 3. Structure of generation (net) of electricity by type of fuel in EU, January 2019 to January 2020 (in \% based on GWh)

(Source: Eurostat)

With a mandate from countries around the world, IRENA encourages governments to adopt enabling policies for renewable energy investments, provides practical tools and policy advice to accelerate renewable energy deployment, and facilitates knowledge sharing and technology transfer to provide clean, sustainable energy for the world's growing population ("IRENA", 2021).

In Figs. 4-23 shows the criteria for energy, economic and environmental efficiency of innovative technologies for the use of renewable energy sources, which analysed in order to conduct a comprehensive assessment of the effectiveness of energy and resource-saving, environmentally friendly and cost-effective innovative technologies in the concept of Sustainable Development. The results of research, shown in Figs. 4 - 23, were obtained by the author with using a database IRENA.

Fig. 4 displays the cumulative renewable energy investment needs in the world from 2016 to 2050 that will result from the full deployment of REmap options by region and category. 


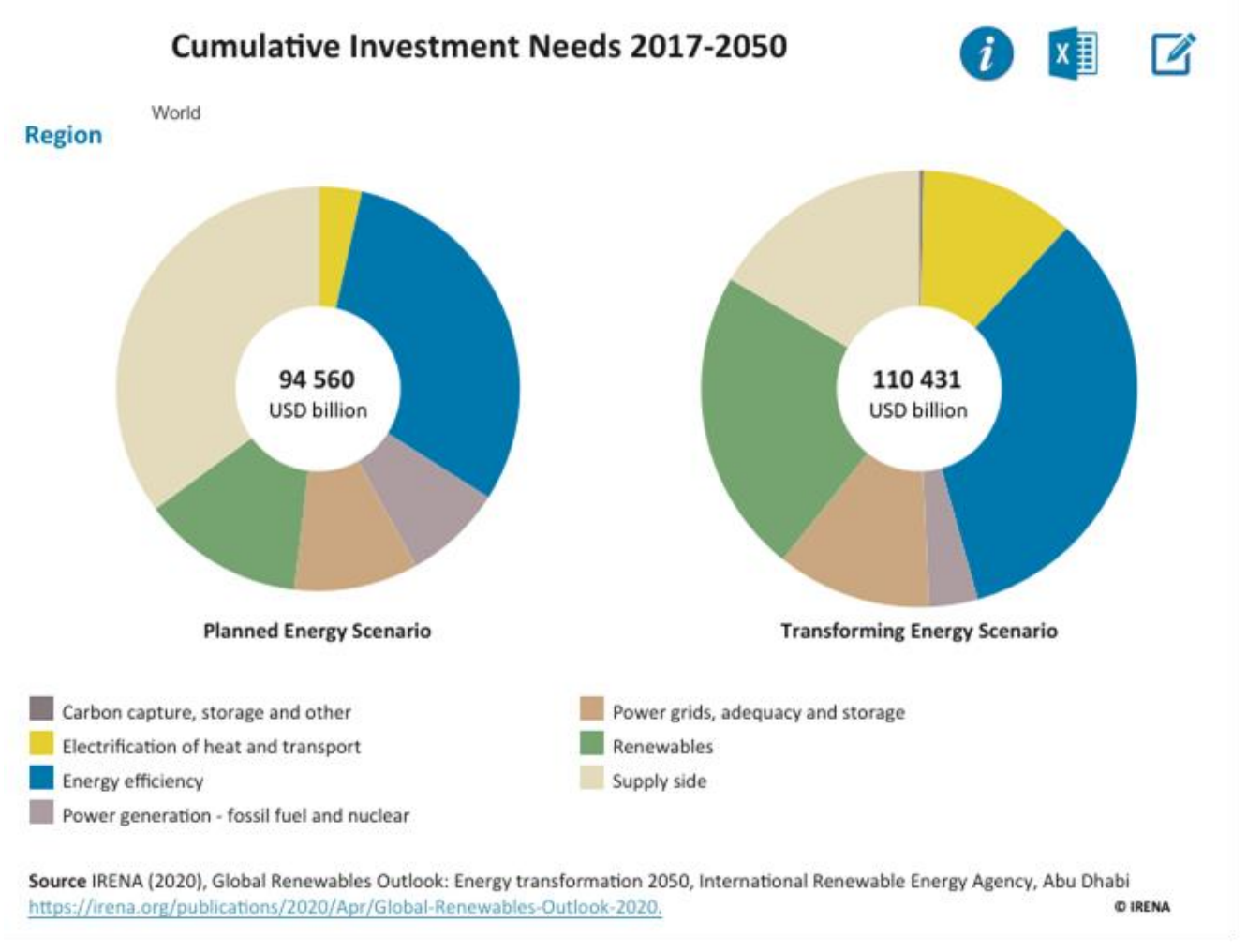

Fig. 4. Cumulative renewable energy investment needs from 2016 to 2050

(Source: author's research results with using database IRENA)

Fig. 5 displays the cumulative renewable energy investment needs in EU-28 from 2016 to 2050 that will result from the full deployment of REmap options by region and category.

\section{Cumulative Investment Needs 2017-2050 i $\times$ 氞 $\square$}

Region EU-28

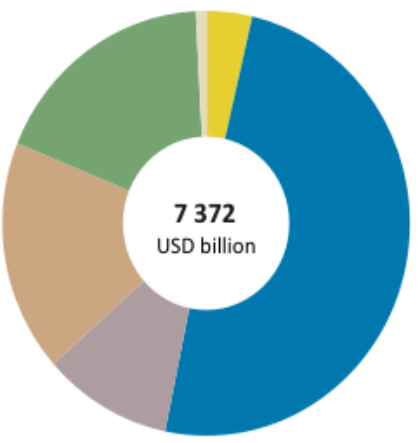

Planned Energy Scenario

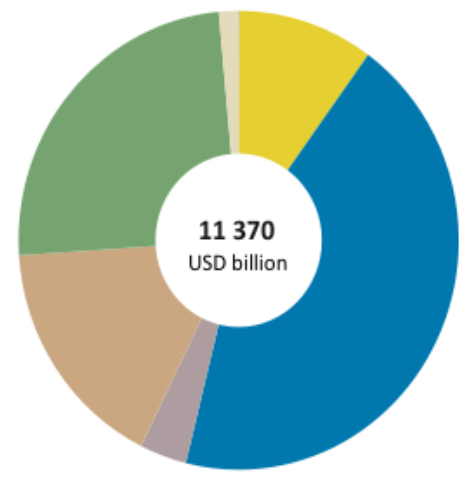

Transforming Energy Scenario
Carbon capture, storage and other

Electrification of heat and transport

Energy efficiency

Power generation - fossil fuel and nuclear

Source IRENA (2020), Global Renewables Outlook: Energy transformation 2050, International Renewable Energy Agency, Abu Dhabi https://irena.org/publications/2020/Apr/Global-Renewables-Outlook-2020.

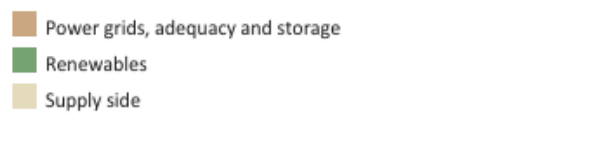

Fig. 5. Cumulative renewable energy investment needs in EU-28 from 2016 to 2050

(Source: author's research results with using database IRENA) 
Fig. 6 provides data by electrical capacity for planned and transforming energy scenario to 2050 for different renewable sources of energy in the world.

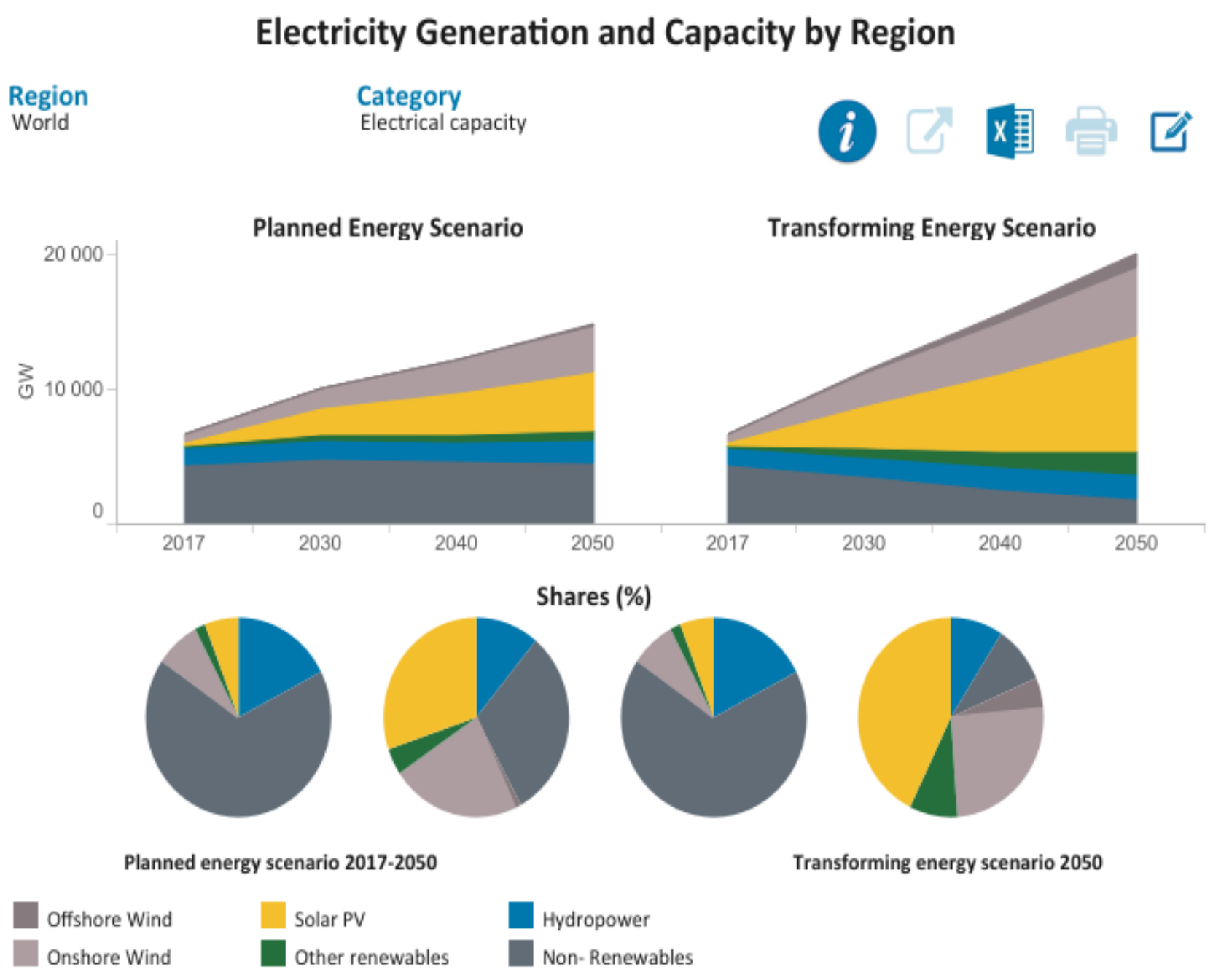

Source IRENA (2020), Global Renewables Outlook: Energy transformation 2050, International Renewable Energy Agency, Abu Dhabi https://irena.org/publications/2020/Apr/Global-Renewables-Outlook-2020.

DIRENA

Fig. 6. Data by electricity generation and power capacity for planned and transforming energy scenario to $\mathbf{2 0 5 0}$ for different renewable sources of energy in the world.

(Source: author's research results with using database IRENA)

Fig. 7 provides data by electricity generation for planned and transforming energy scenario to 2050 for different renewable sources of energy in the world. 


\section{Electricity Generation and Capacity by Region}

$\begin{array}{ll}\text { Region } & \text { Category } \\ \text { World } & \text { Electricity generation }\end{array}$

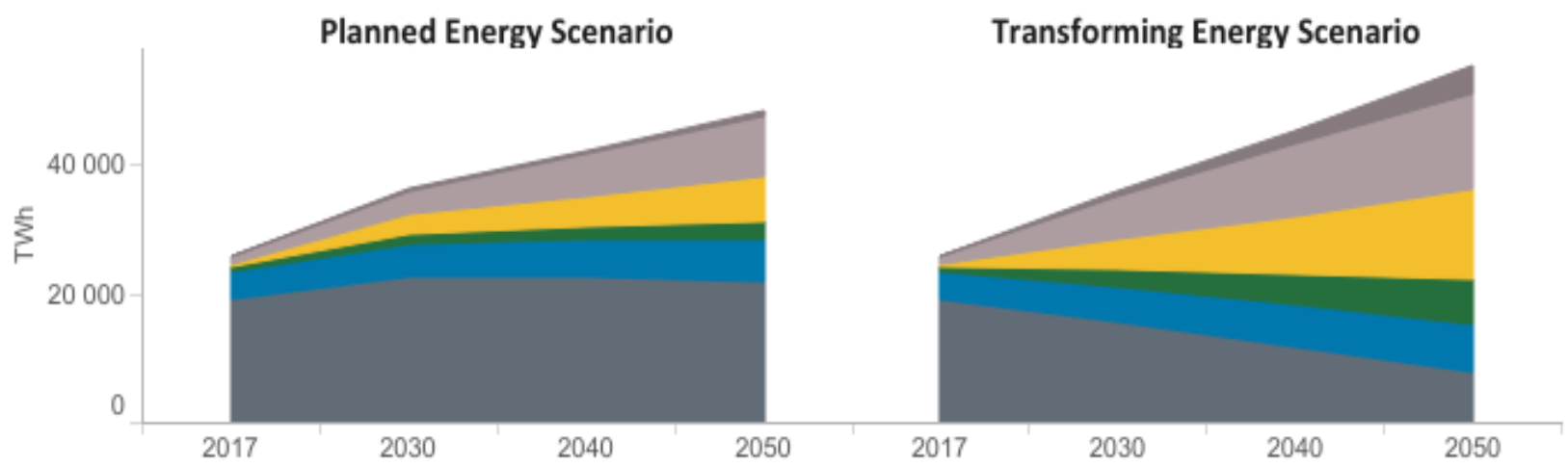

Shares (\%)

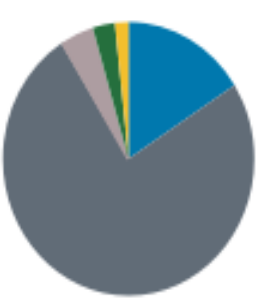

Planned energy scenario 2017-2050

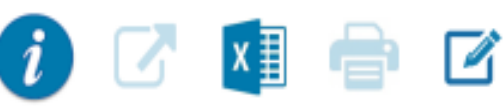

2030

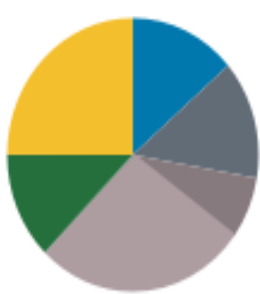

Transforming energy scenario $\mathbf{2 0 5 0}$

Fig. 7. Data by electricity generation for planned and transforming energy scenario to 2050 for different renewable sources of energy in the world

Source: author's research results with using database IRENA

Fig. 8 provides data by electrical capacity for planned and transforming energy scenario to 2050 for different renewable sources of energy in EU-28. 


\section{Electricity Generation and Capacity by Region}
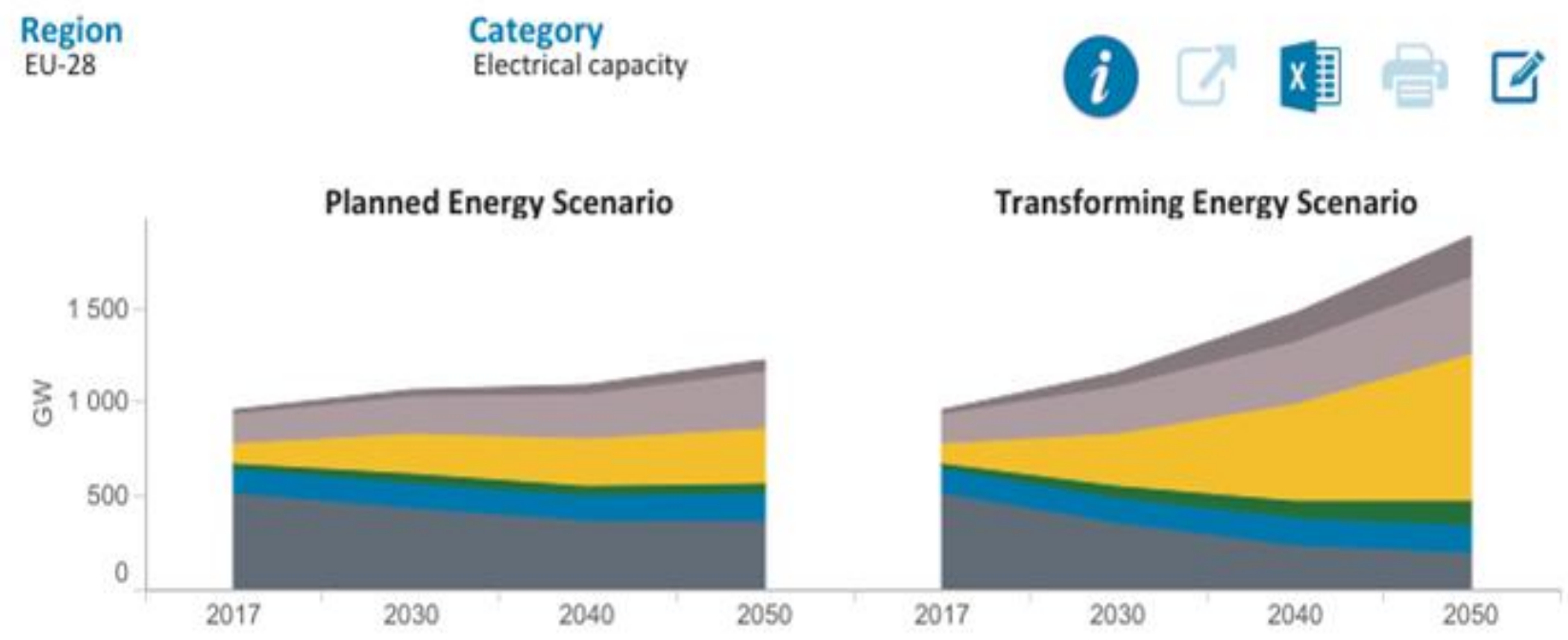

Shares (\%)
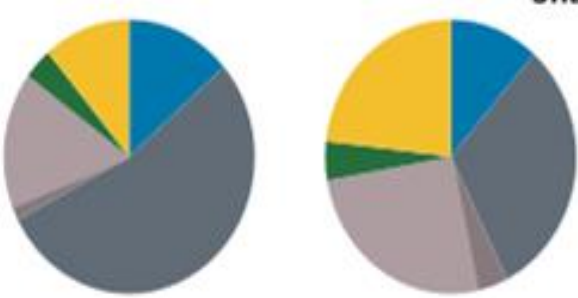

Planned energy scenario 2017-2050

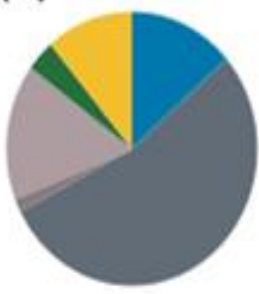

Transforming energy scenario 2050

Offshore Wind

Onshore Wind

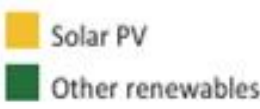

Hydropower

Non-Renewables

Source IRENA (2020), Global Renewables Outlook: Energy transformation 2050, International Renewable Energy Agency, Abu Dhabi https://irena.org/publications/2020/Apr/Global-Renewables-Outlook-2020.

Fig. 8. Data by electrical capacity for planned and transforming energy scenario to 2050 for different renewable sources of energy in EU-28

(Source: author's research results with using database IRENA)

Fig. 9 provides data by electricity generation for planned and transforming energy scenario to 2050 for different renewable sources of energy in EU-28. 


\section{Electricity Generation and Capacity by Region}
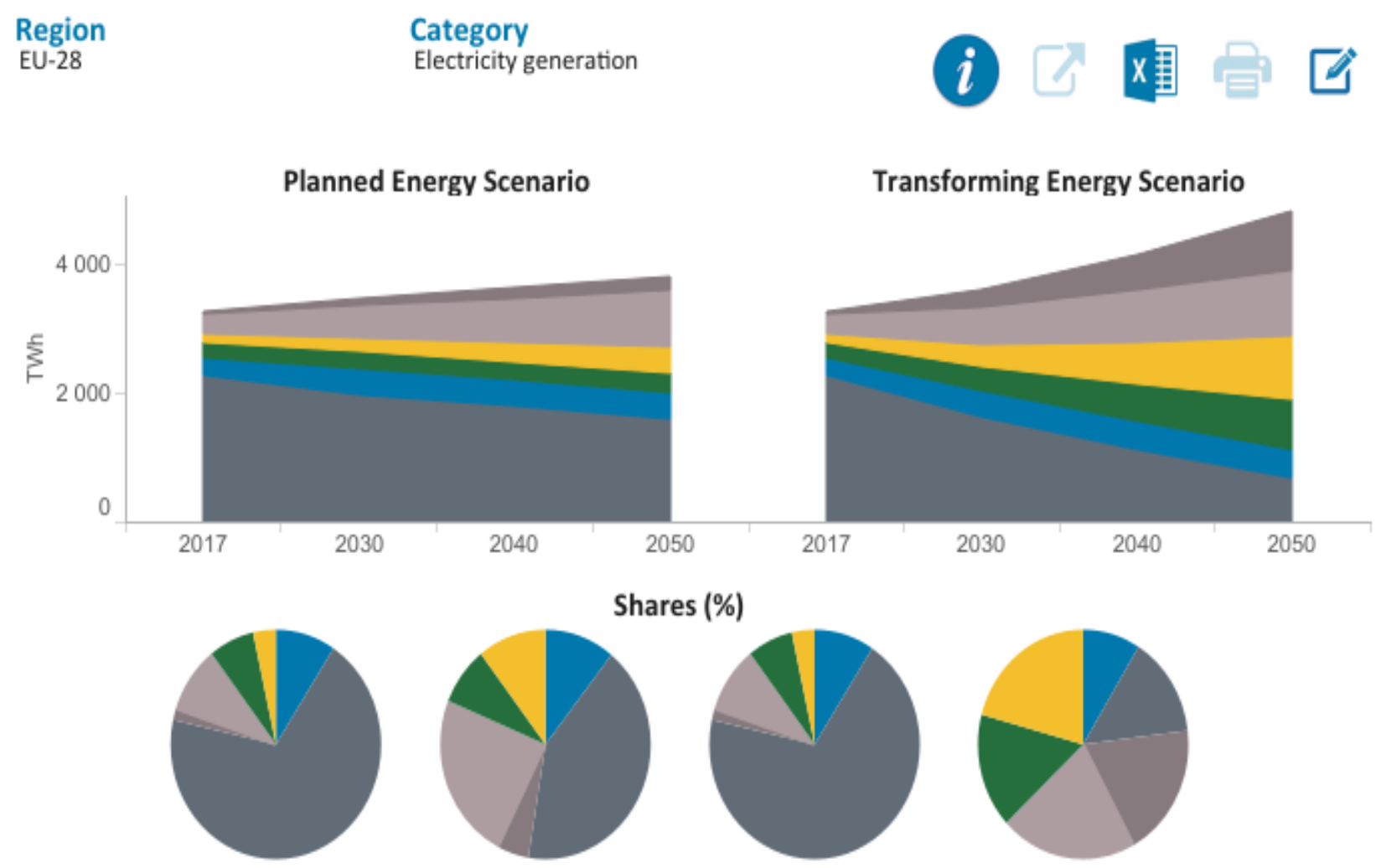

Planned energy scenario 2017-2050

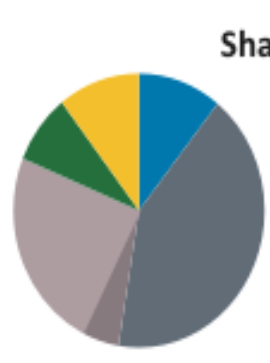

Shares (\%)

Offshore Wind

Solar PV
Other renewables

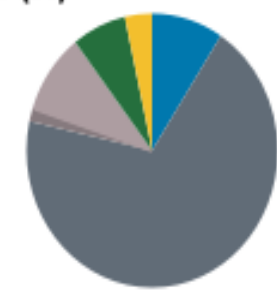

Transforming energy scenario 2050

Onshore Wind

Other renewables

Hydropower

Non- Renewables

Source IRENA (2020), Global Renewables Outlook: Energy transformation 2050, International Renewable Energy Agency, Abu Dhabi https://irena.org/publications/2020/Apr/Global-Renewables-Outlook-2020.

OIRENA

Fig. 9. Data by electricity generation for planned and transforming energy scenario to 2050 for different renewable sources of energy in EU-28

(Source: author's research results with using database IRENA)

Fig. 10 provides an overview of the total primary energy supply (TPES) for planned and transforming energy scenario to 2050 for different sources of energy in the world. 


\section{Energy Demand and Supply}

Region

World
Show by

Total Primary Energy Supply

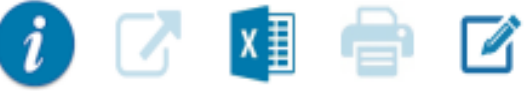

Transforming energy scenario 2050

Share of renewable energy

Planned energy scenario 2017, 2050
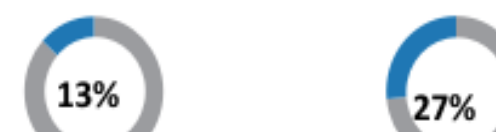

$65 \%$

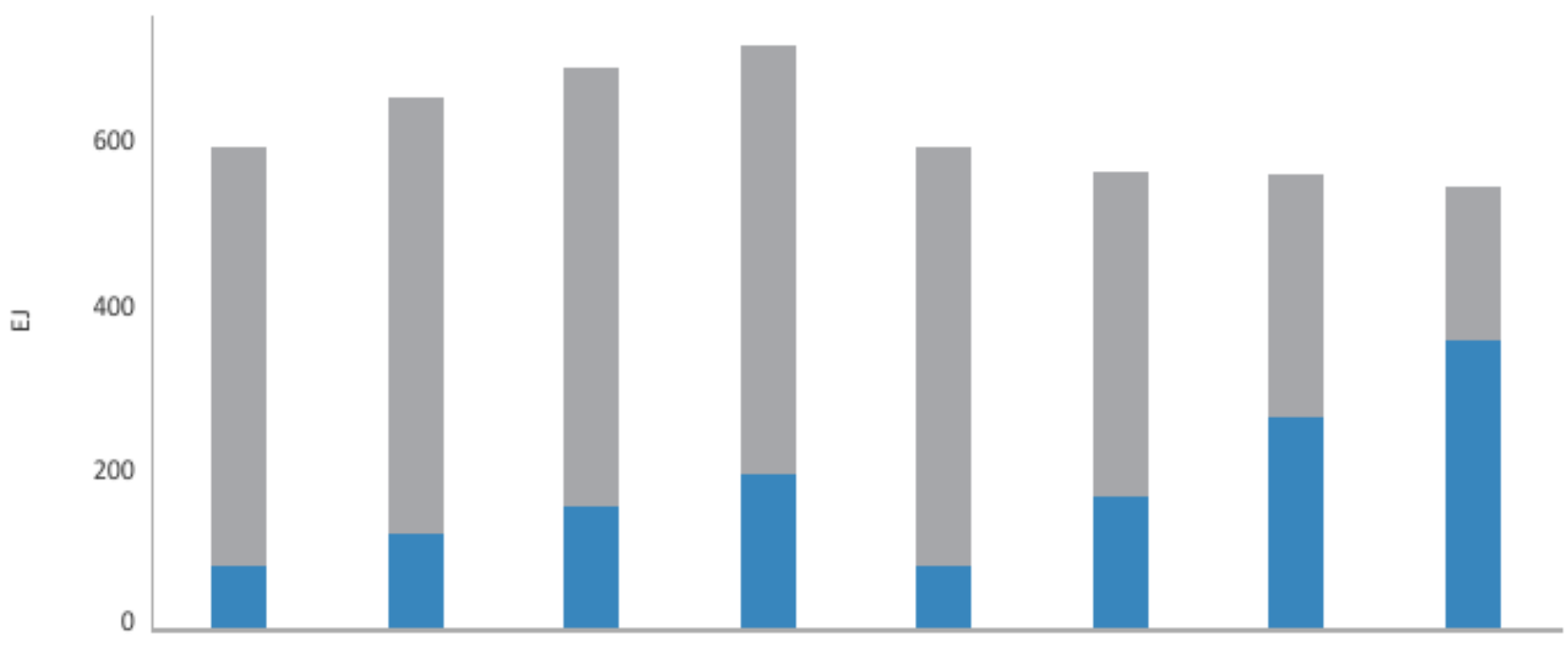

Planned energy scenario 2017, 2030, 2040, 2050

Transforming energy scenario 2030, 2040,2050

Non-renewables

Renewables

Source IRENA (2020), Global Renewables Outlook: Energy transformation 2050, International Renewable Energy Agency, Abu Dhabi https://irena.org/publications/2020/Apr/Global-Renewables-Outlook-2020.

Fig. 10. The total primary energy supply (TPES) for planned and transforming energy scenario to 2050 for different sources of energy in the world

(Source: author's research results with using database IRENA)

Fig. 11 provides an overview of the total primary energy supply (TPES) for planned and transforming energy scenario to 2050 for different sources of energy in EU-28 


\section{Energy Demand and Supply}

$\begin{array}{ll}\text { Region } & \text { Show by } \\ \text { EU-28 } & \text { Total Primary Energy Supply }\end{array}$

Planned energy scenario 2017, 2050

Share of renewable energy
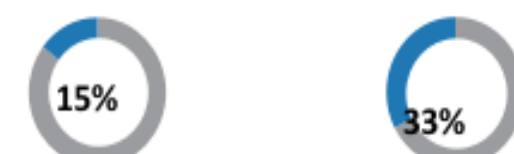

Transforming energy scenario 2050

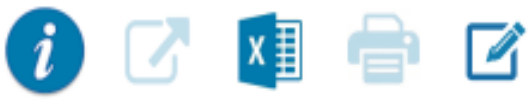

$71 \%$

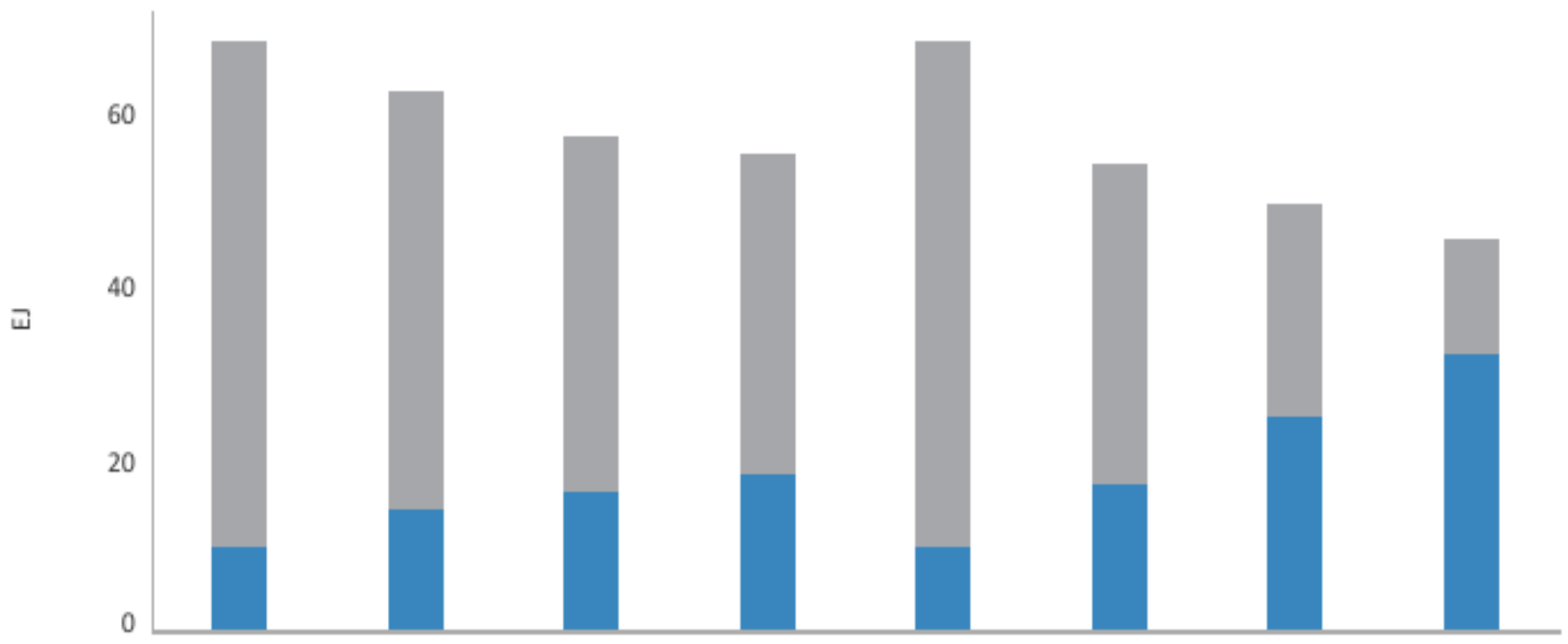

Planned energy scenario 2017, 2030, 2040, 2050

Transforming energy scenario 2030, 2040,2050

Non-renewables Renewables

Source IRENA (2020), Global Renewables Outlook: Energy transformation 2050, International Renewable Energy Agency, Abu Dhabi https://irena.org/publications/2020/Apr/Global-Renewables-Outlook-2020.

Fig. 11. The total primary energy supply (TPES) for planned and transforming energy scenario to 2050 for different sources of energy in EU-28

(Source: author's research results with using database IRENA)

Fig. 12 provides an overview of the total final energy consumption by sector (TFEC) for planned and transforming energy scenario to 2050 in the world. 


\section{Energy Demand and Supply}

Region

World
Show by

Total Final Energy Consumption

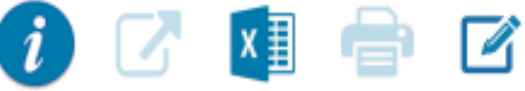

Transforming energy scenario 2050

Share of renewable energy
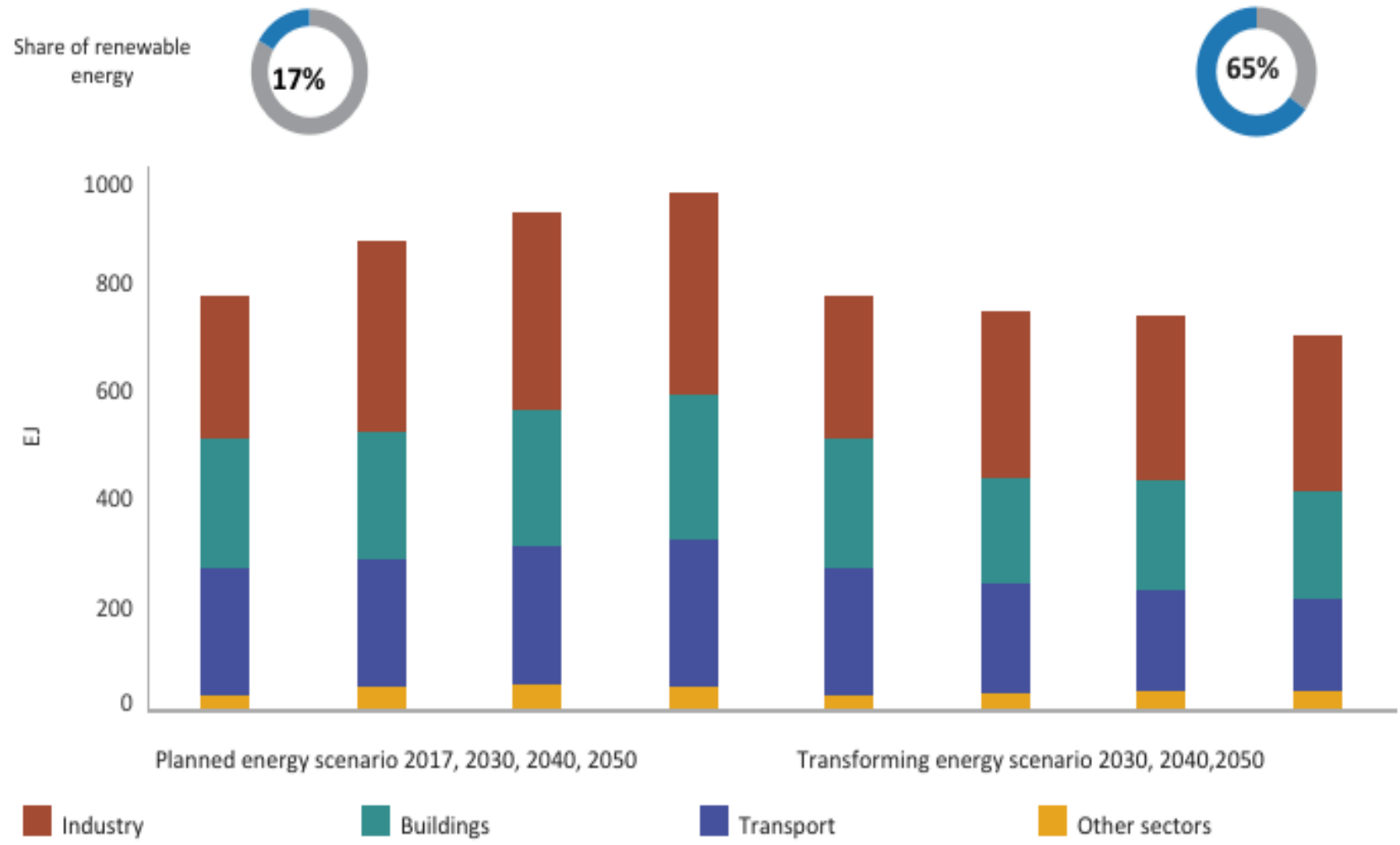

Source IRENA (2020), Global Renewables Outlook: Energy transformation 2050, International Renewable Energy Agency, Abu Dhabi https://irena.org/publications/2020/Apr/Global-Renewables-Outlook-2020.

Fig. 12. The total final energy consumption by sector (TFEC) for planned and transforming energy scenario to 2050 in the world

(Source: author's research results with using database IRENA)

Fig. 13 provides an overview of the total final energy consumption by sector (TFEC) for planned and transforming energy scenario to 2050 in EU-28 


\section{Energy Demand and Supply}

Region

EU-28
Show by

Total Final Energy Consumption

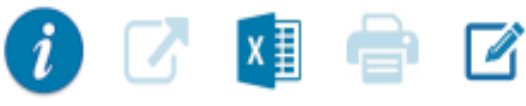

Transforming energy scenario 2050

$69 \%$

Share of renewable energy

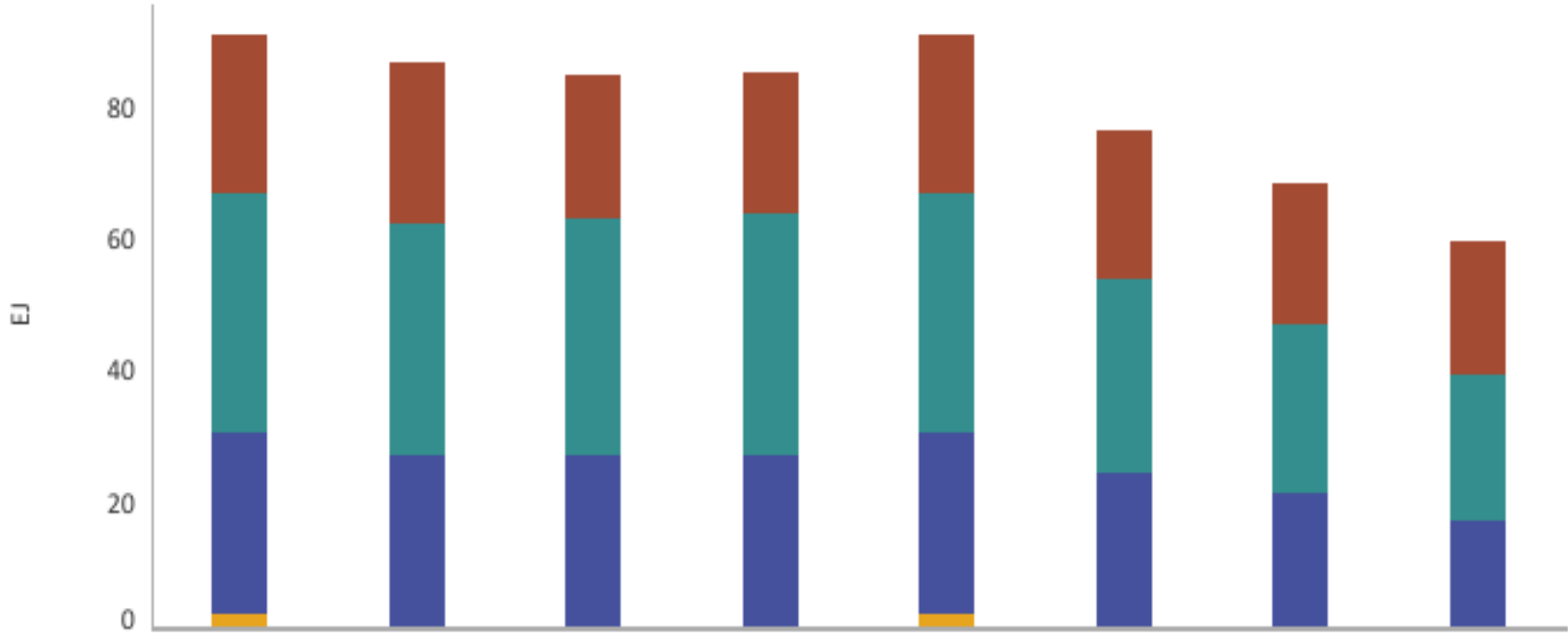

Planned energy scenario 2017, 2030, 2040, 2050

Transforming energy scenario 2030, 2040,2050

Industry

Buildings

Transport

Other sectors

Source IRENA (2020), Global Renewables Outlook: Energy transformation 2050, International Renewable Energy Agency, Abu Dhabi https://irena.org/publications/2020/Apr/Global-Renewables-Outlook-2020.

Fig. 13. The total final energy consumption by sector (TFEC) for planned and transforming energy scenario to 2050 in EU-28

(Source: author's research results with using database IRENA)

Fig. 14 shows the key highlights from the latest Renewable Energy Auctions report that provides key updates on this crucial mechanism for price discovery and market development. 


\section{Global Trends in Renewable Energy Auctions}

Global weighted average prices resulting from auctions from 2010 to 2018, and capacity award..

Technology

All

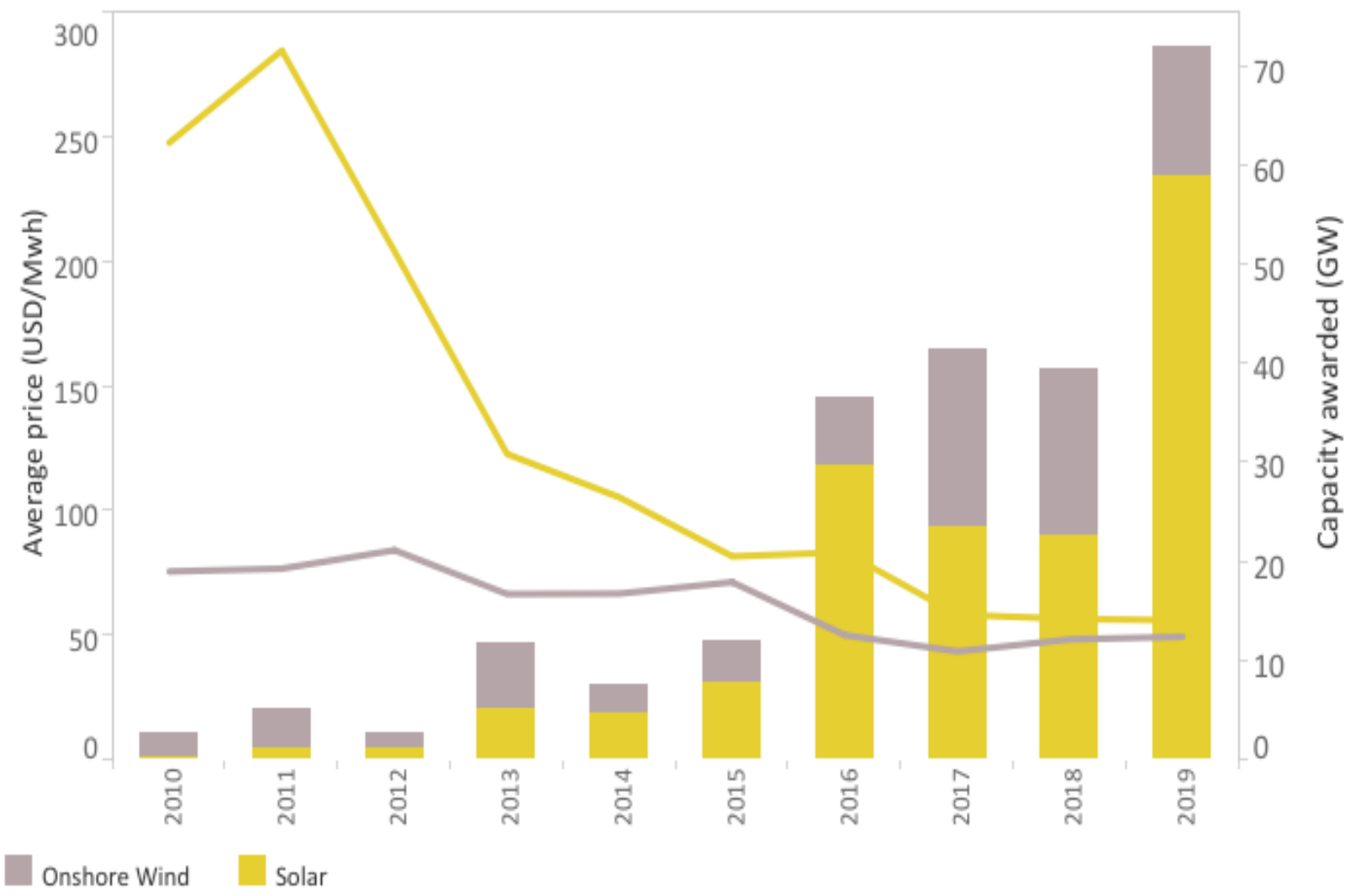

Source: IRENA Database, n.d., based on BNEF, 2019a and PSR, n.d.

Notes: This figure shows awarded volumes. The graph depicts awarded weighted average global prices from () IRENAins between January 2010 and December 2019, excluding feed-in-premium auctions

Fig. 14. The key highlights from the latest Renewable Energy Auctions (solar and wind technology)

(Source: author's research results with using database IRENA)

Fig. 15 provides an overview on the latest wind costs for wind projects. 


\section{Weighted-average LCOE of newly commissioned onshore wind projects by country,}

1984-2019..

Country

Multiple values

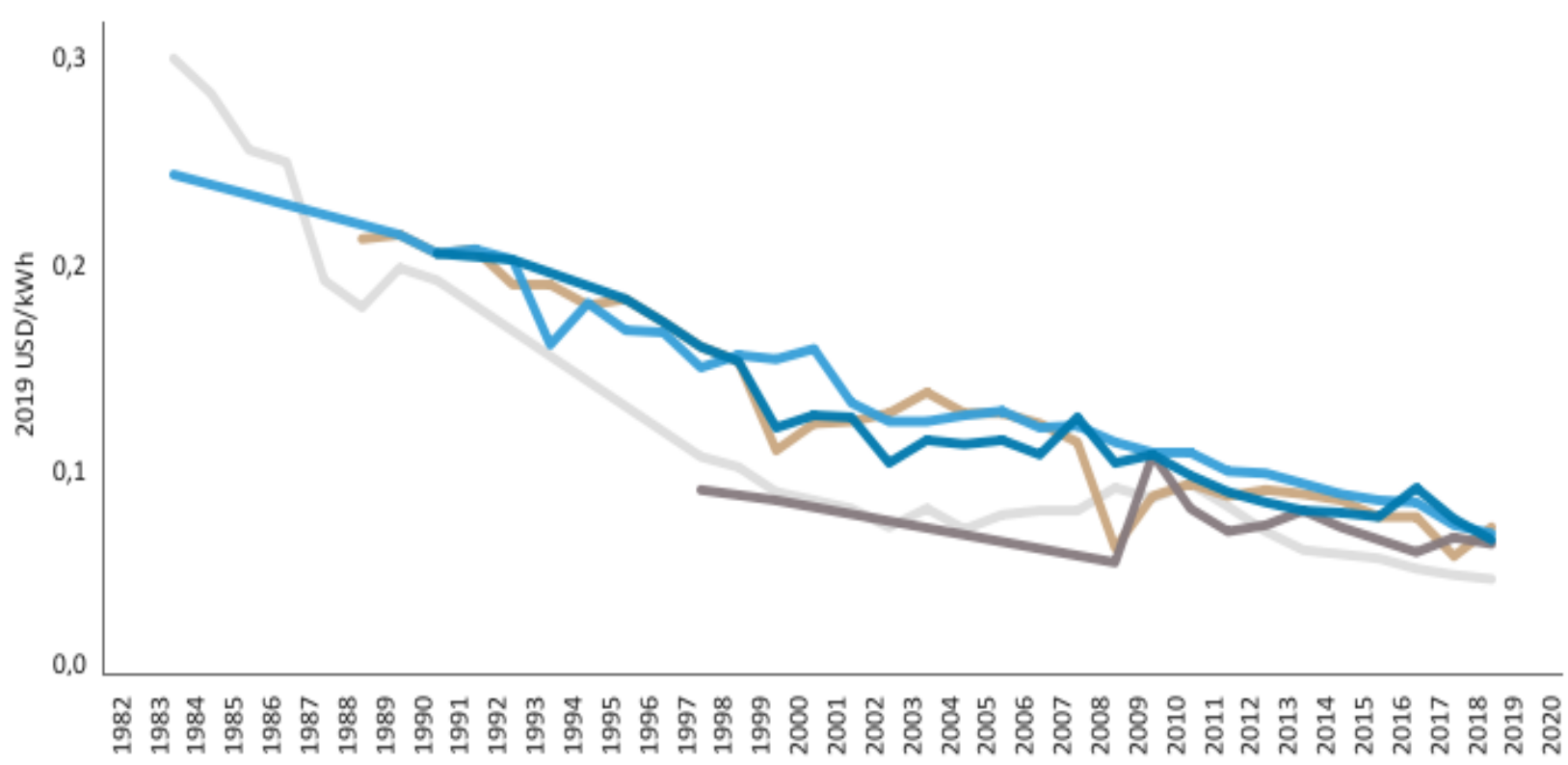

France

Germany

Turkey

United Kingdom

United States

Note: All LCOE values are calculated based on project level data for total installed costs and capacity factors from the IRENA Renewable Cost Database, with other assumptions necessary for LCOE detailed in the source link below, notably an assumption of a weighted-average cost of capital of $7.5 \%$ real in the OECD and China and $10 \%$ elsewhere.

Source: IRENA (2020), Renewable Power Generation Costs in 2019, International Renewable Energy Agency, Abu Dhabi https://www.irena.org/publications/2020/Jun/Renewable-Power-Costs-in-2019

Fig. 15. Overview on the latest wind costs

(Source: author's research results with using database IRENA)

Fig. 16 provides an overview on the latest Solar PV costs. 


\section{Weighted-average LCOE of newly commissioned utility-scale solar PV projects by country, 2010-2019..}

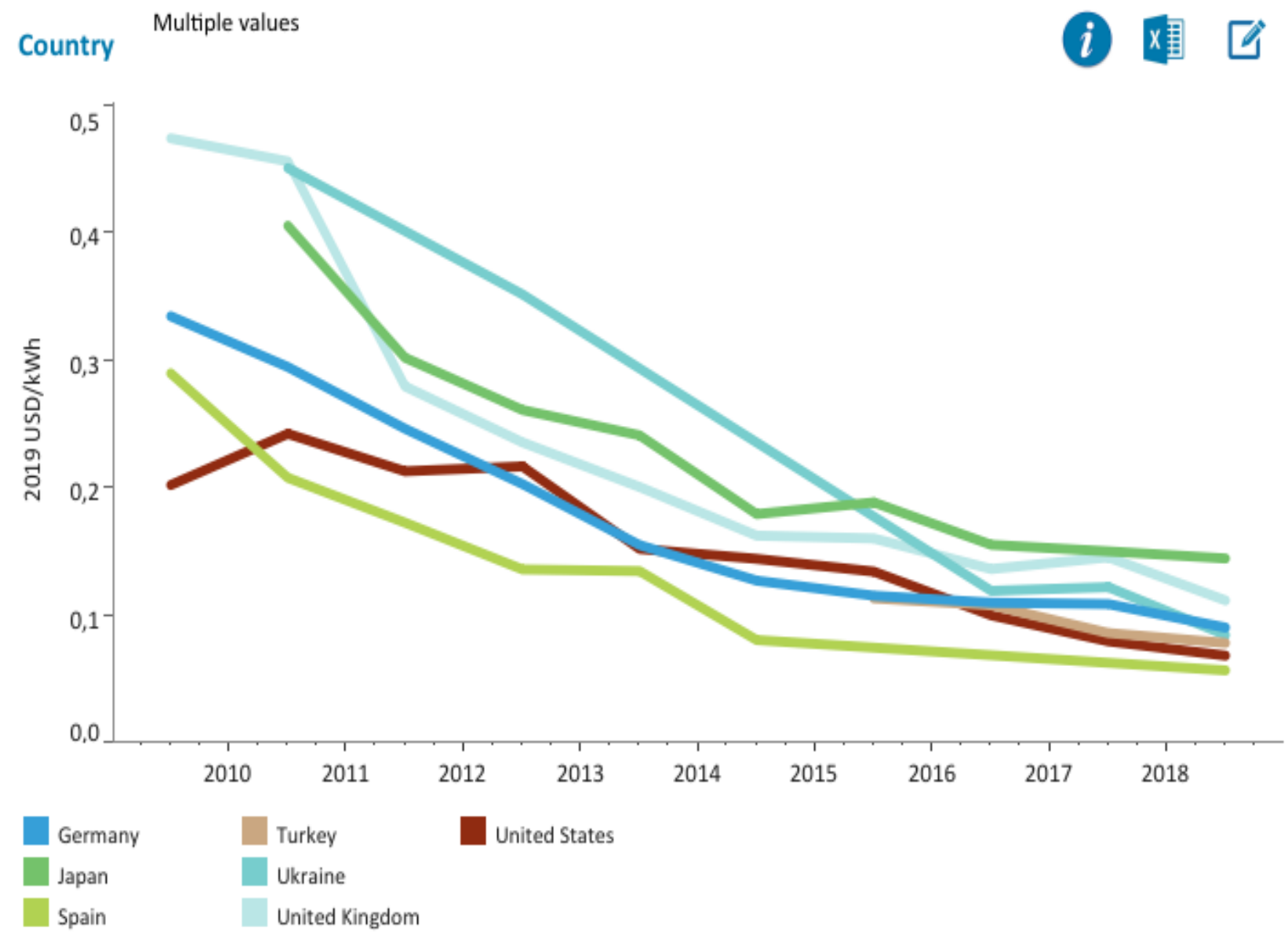

Note: All LCOE values are calculated based on project level data for total installed costs and capacity factors from the IRENA Renewable Cost Database, with other assumptions necessary for LCOE detailed in the source link below, notably an assumption of a weighted-average cost of capital of $7.5 \%$ real in the OECD and China and $10 \%$ elsewhere.

Source: IRENA (2020), Renewable Power Generation Costs in 2019, International Renewable Energy Agency, Abu Dhabi https://www.irena.org/publications/2020/Jun/Renewable-Power-Costs-in-2019 Q IRENA

Fig. 16. Overview on the latest Solar PV costs

(Source: author's research results with using database IRENA)

Fig. 17 provides an overview on trends in global weighted average Levelised Cost of Energy (LCOE) and auction values. 


\section{Global weighted average LCOE and auction values 2010-2023}

Hover over data point for the raw values and key highlights

Technology

Concentrating solar power
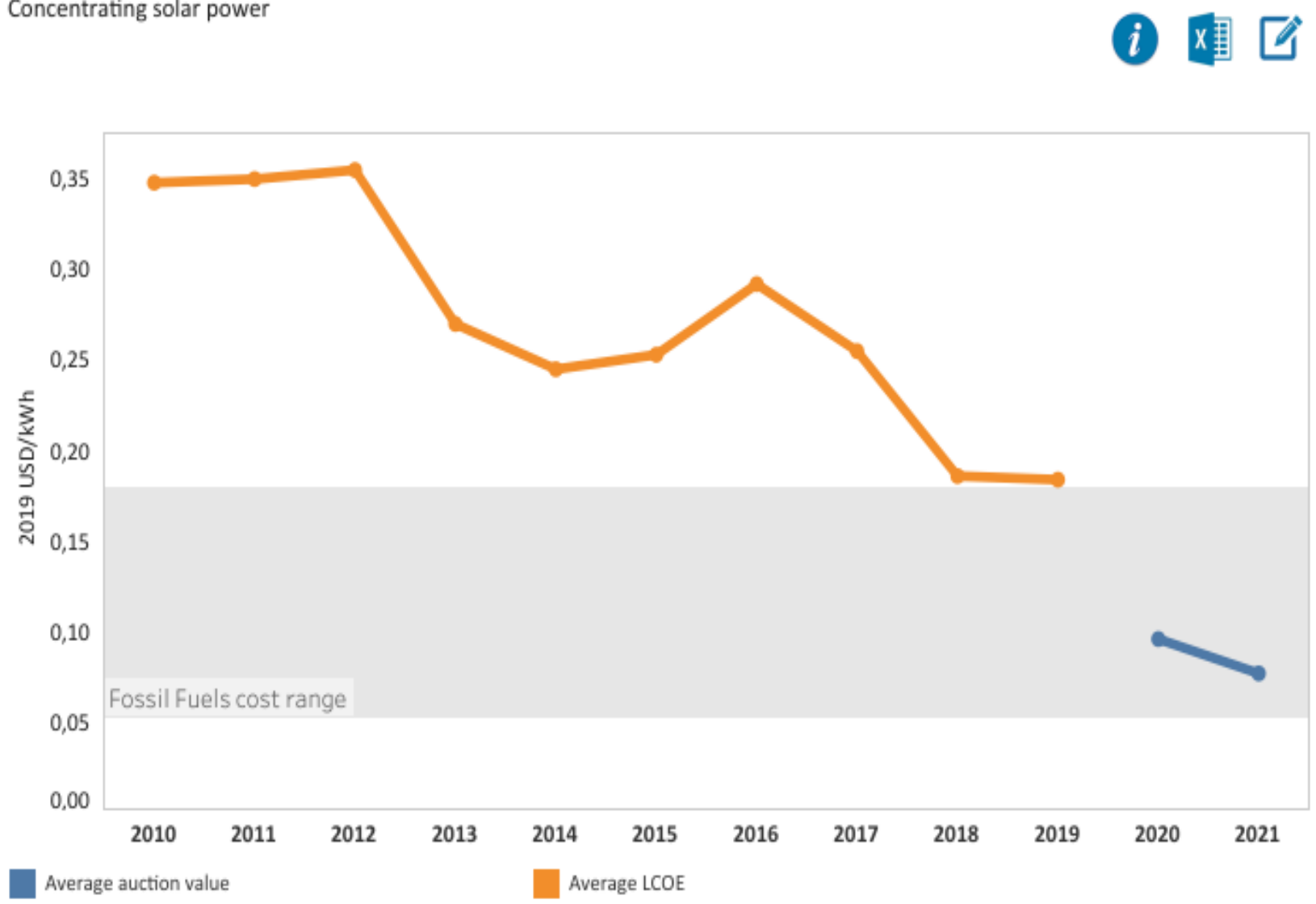

Note: All LCOE values are calculated based on project level data for total installed costs and capacity factors from the IRENA Renewable Cost Database, with other assumptions necessary for LCOE detailed in the source link below, notably an assumption of a weighted-average cost of capital of 7.5\% real in the OECD and China and $10 \%$ elsewhere. Auction price data is corrected for inflation, but care must be taken in interpreting the results as not all PPA/Auction prices are directly comparable to LCOE values."

Source: IRENA (2020), Renewable Power Generation Costs in 2019, International Renewable Energy Agency, Abu Dhabi https://www.irena.org/publications/2020/Jun/Renewable-Power-Costs-in-2019

Fig. 17. Overview on trends in global weighted average Levelised Cost of Energy (LCOE) and auction values

(Source: author's research results with using database IRENA)

Fig. 18 provides an overview on latest global trends in renewable energy costs (on example of geothermal energy). It displays global weighted average total installed costs, capacity factors and LCOE by technology. 
Global weighted average total installed costs, capacity factors and LCOE 2010-2019 Hover over data point for the raw values and key highlights

Technology Geothermal

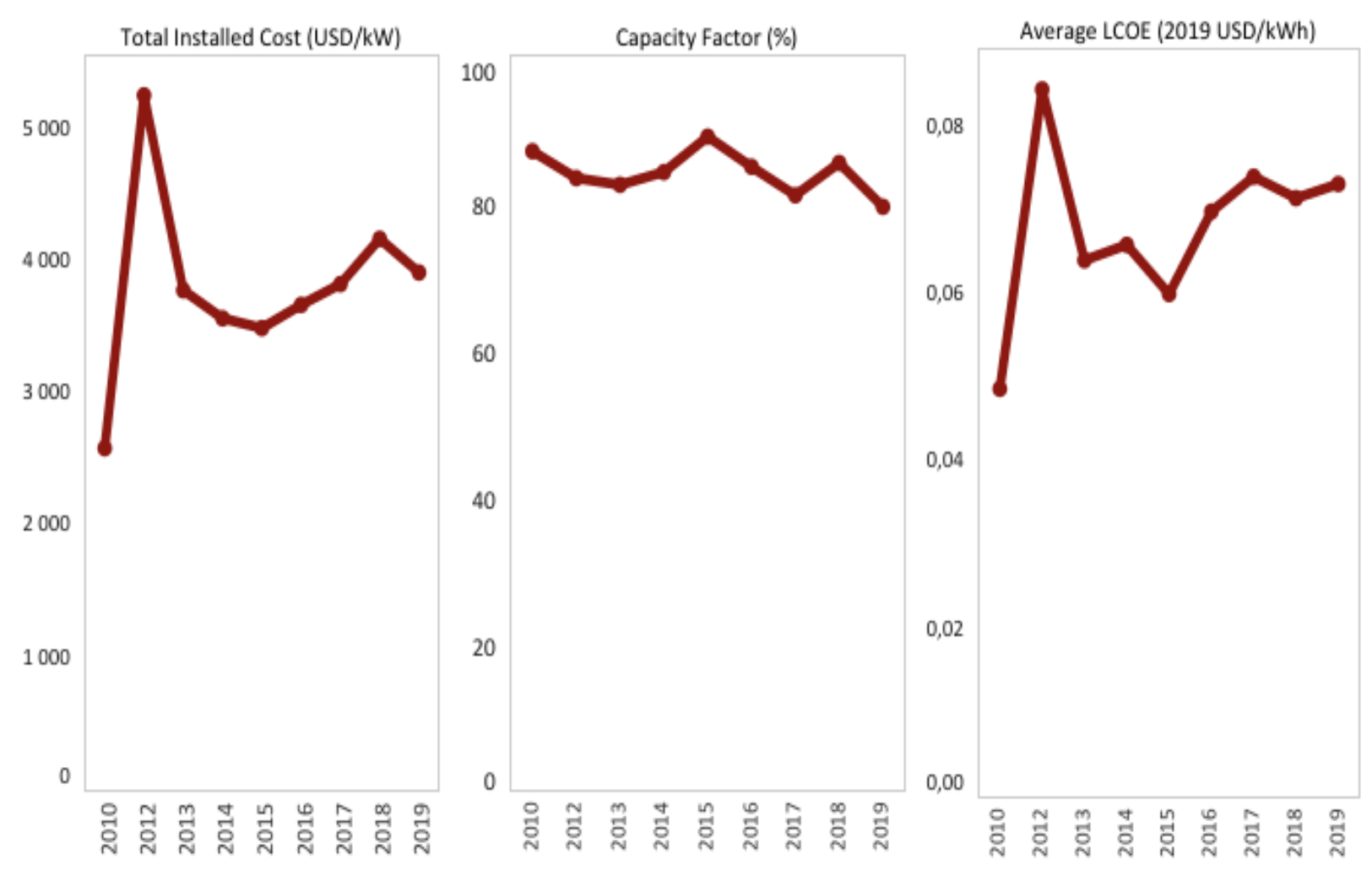

Geothermal

Note: All LCOE values are calculated based on project level data for total installed costs and capacity factors from the IRENA Renewable Cost Database, with other assumptions necessary for LCOE detailed in the source link below, notably an assumption of a weighted-average cost of capital of 7.5\% real in the OECD and China and $10 \%$ elsewhere.

Source: IRENA (2020), Renewable Power Generation Costs in 2019, International Renewable Energy Agency, Abu Dhabi

https://www.irena.org/publications/2020/Jun/Renewable-Power-Costs-in-2019

Fig. 18. Overview on latest global trends in renewable energy costs (on example of geothermal energy)

(Source: author's research results with using database IRENA)

Figs. 19, 20 provides an overview of renewable energy finance flows by development financial institutions. It covers investments linked to renewable energy project assets between the years 20092017. 


\section{Public Investment Trends in Renewables}

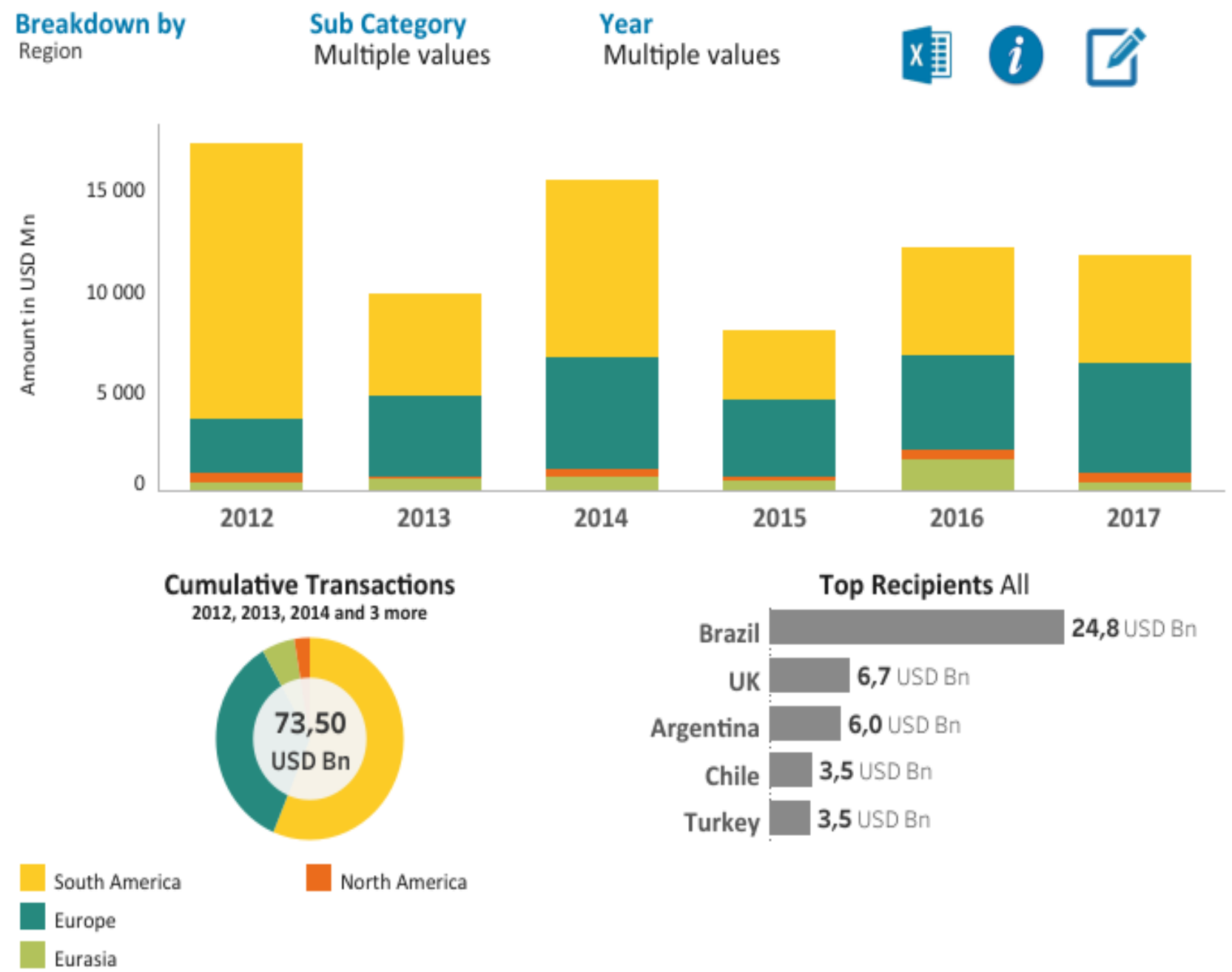

(C) IRENA Displayed data represents the information available in IRENA's database. ${ }^{*}$ Multiple renewables refer to commitments that target more than one renewable energy technology. These could be equity investments, green bonds, investment funds, multiple project commitments, projects that combine technologies (e.g., hybrid minigrids) and any other commitment that cannot be clearly categorised under one single technology.

Fig. 19. Overview of renewable energy finance flows by development financial institutions between the years 2009-2017

(Source: author's research results with using database IRENA) 


\section{Public Investment Trends in Renewables}

Breakdown by Region

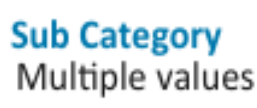

Year

Multiple values
颔 6 近
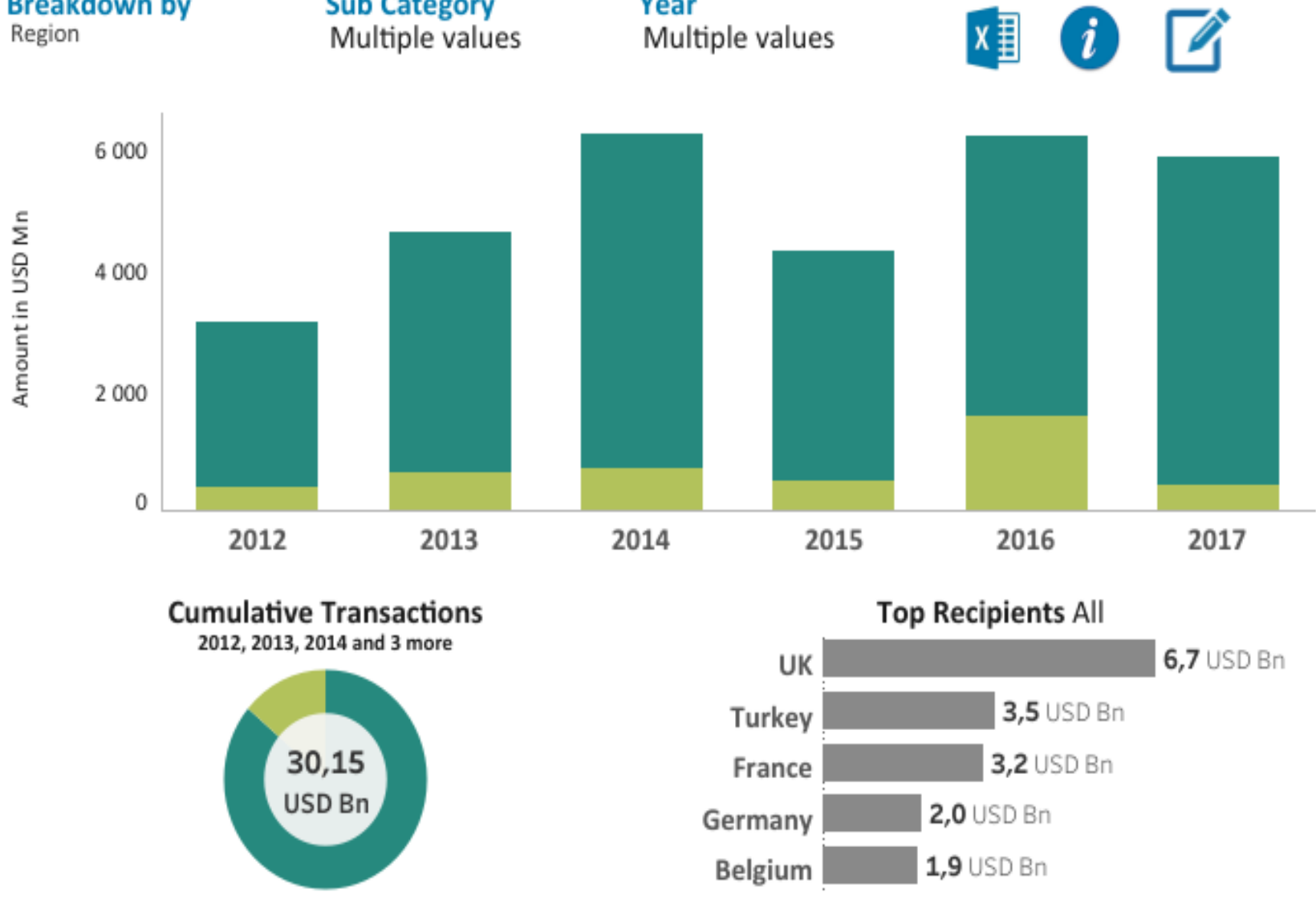

Europe

Eurasia

(C) IRENA Displayed data represents the information available in IRENA's database.*Multiple renewables refer to commitments that target more than one renewable energy technology. These could be equity investments, green bonds, investment funds, multiple project commitments, projects that combine technologies (e.g., hybrid minigrids) and any other commitment that cannot be clearly categorised under one single technology.

Fig. 20. Overview of renewable energy finance flows by development financial institutions between the years 2009-2017

(Source: author's research results with using database IRENA)

Fig. 21 provides an overview on global renewable energy investment trends between the years 2013-2018 


\section{Annual Financial Commitments in Renewable Energy}

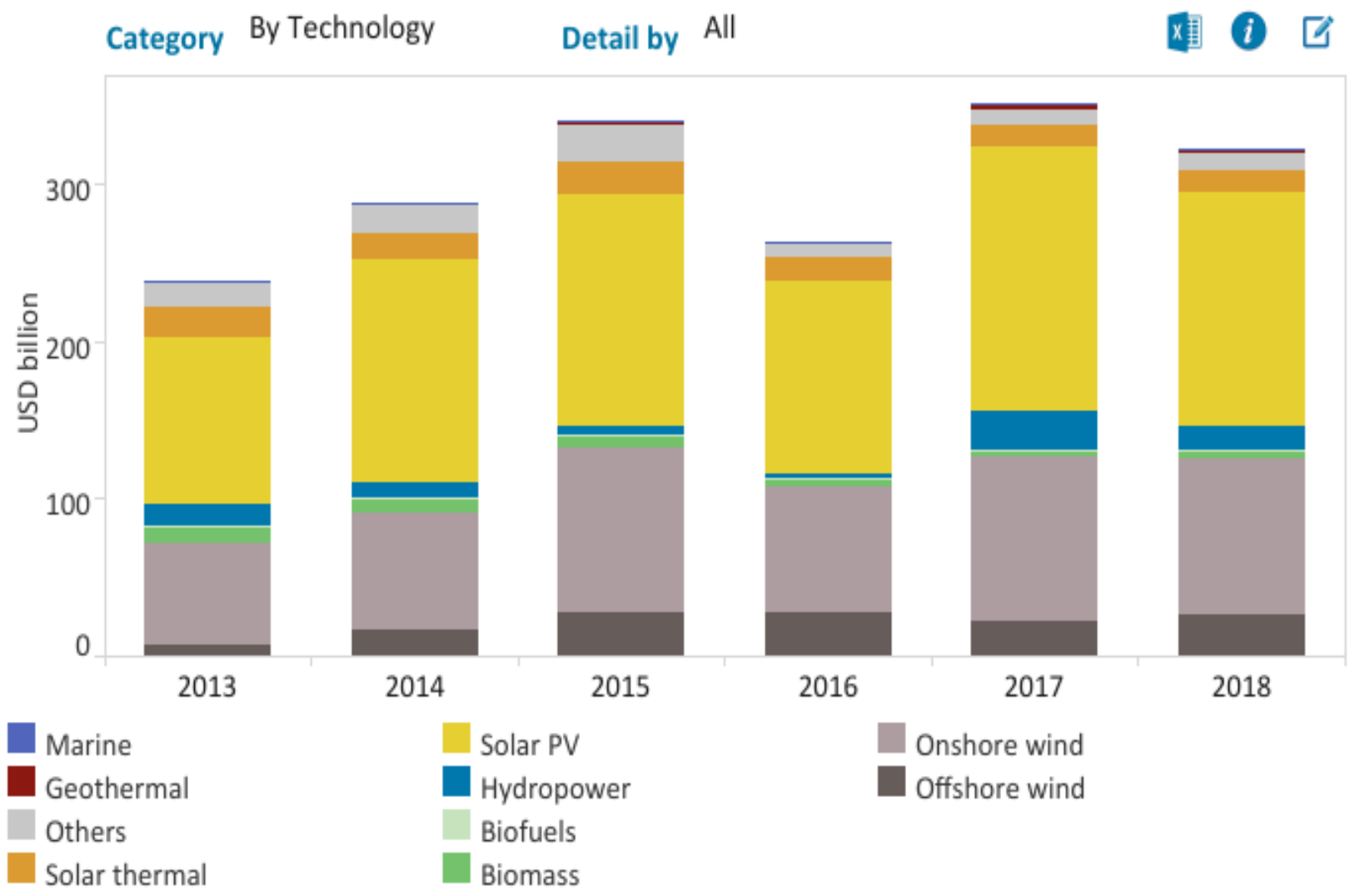

In 2013-2018, solar PV and onshore wind consolidated their dominance, attracting, respectively, $46 \%$ and $29 \%$ of global renewable energy investments. Investment in offshore wind has picked up, attracting $7 \%$ of the total, followed by solar thermal at $6 \%$. Other renewable energy technologies (including hydropower, biomass, biofuels, geothermal and marine energy) altogether contributed only $7 \%$ of total investment in 2013-2018, with hydropower making up a relatively significant portion of the total.

Fig. 21. Overview on global renewable energy investment trends between the years 2013-2018

(Source: author's research results with using database IRENA)

Fig. 22 provides information on the annual energy-related $\mathrm{CO} 2$ emissions by sector for the reference case and REmap case by year for planned and transforming energy scenario to 2050 in the world. 


\section{Annual energy-related $\mathrm{CO}_{2}$ emissions}

$\begin{array}{lll}\text { Region } & \text { Case } & \text { Sector } \\ \text { World } & \text { All } & \text { All }\end{array}$

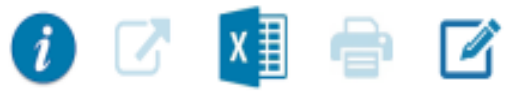

Planned Energy Scenario

Transforming Energy Scenario

30000

$\sum^{20000}$

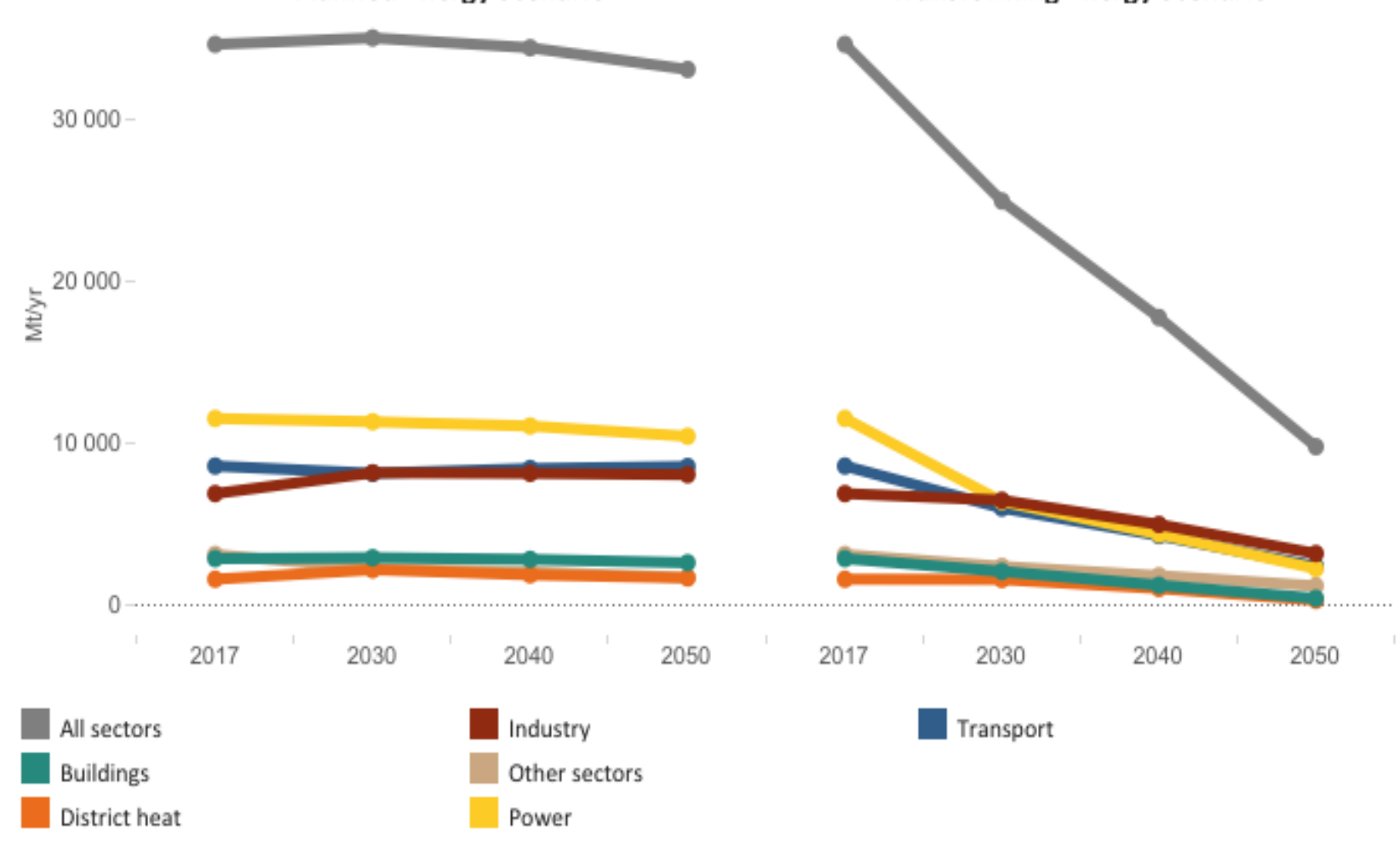

10000

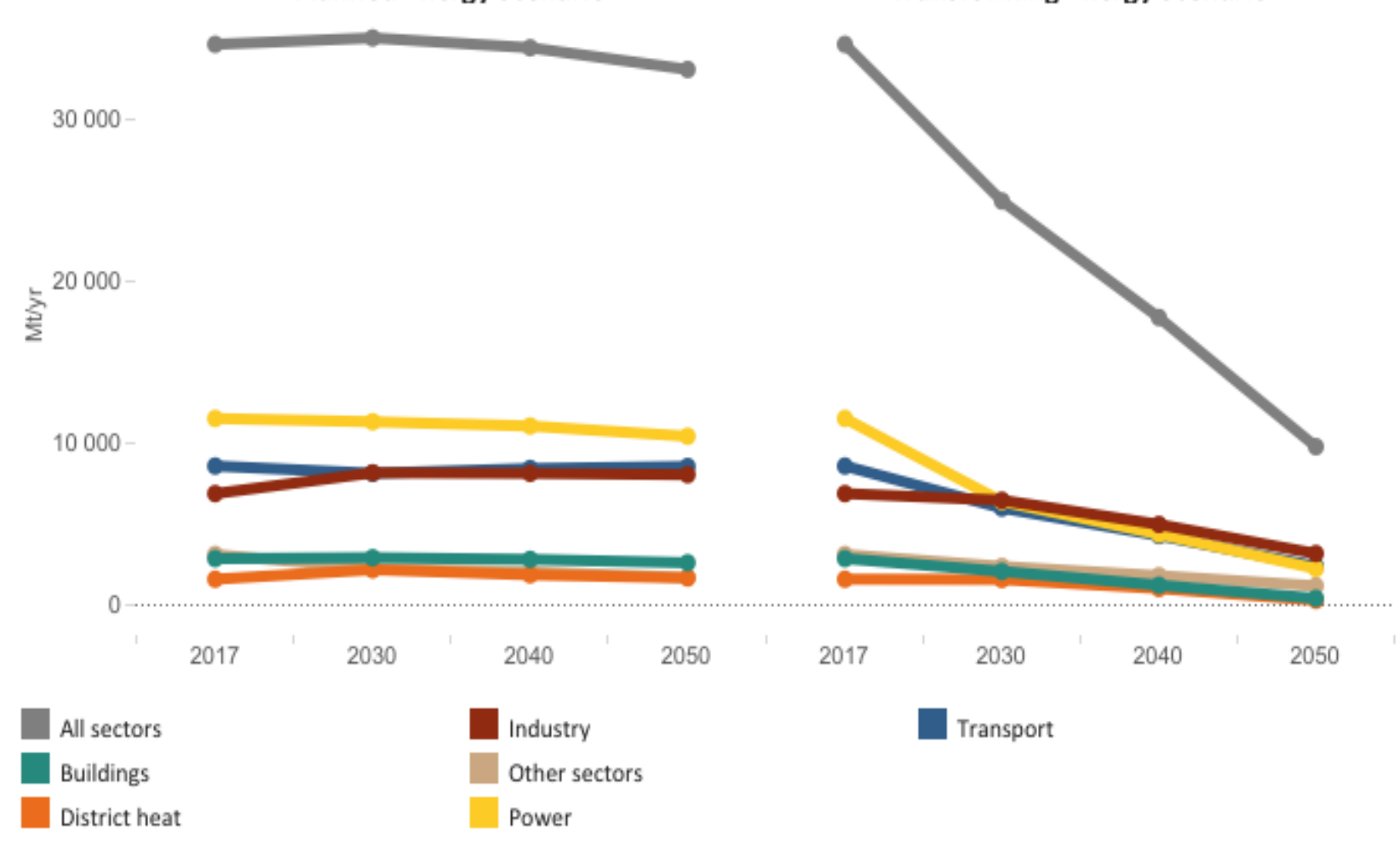

Sector

$i$

Source IRENA (2020), Global Renewables Outlook: Energy transformation 2050, International Renewable Energy Agency, Abu Dhabi https://irena.org/publications/2020/Apr/Global-Renewables-Outlook-2020.

DIRENA

Fig. 22. The annual energy-related $\mathrm{CO} 2$ emissions by sector for the reference case and REmap case by year for planned and transforming energy scenario to 2050 in the world (Source: author's research results with using database IRENA)

Fig. 23 provides information on the annual energy-related $\mathrm{CO} 2$ emissions by sector for the reference case and REmap case by year for planned and transforming energy scenario to 2050 in EU28. 


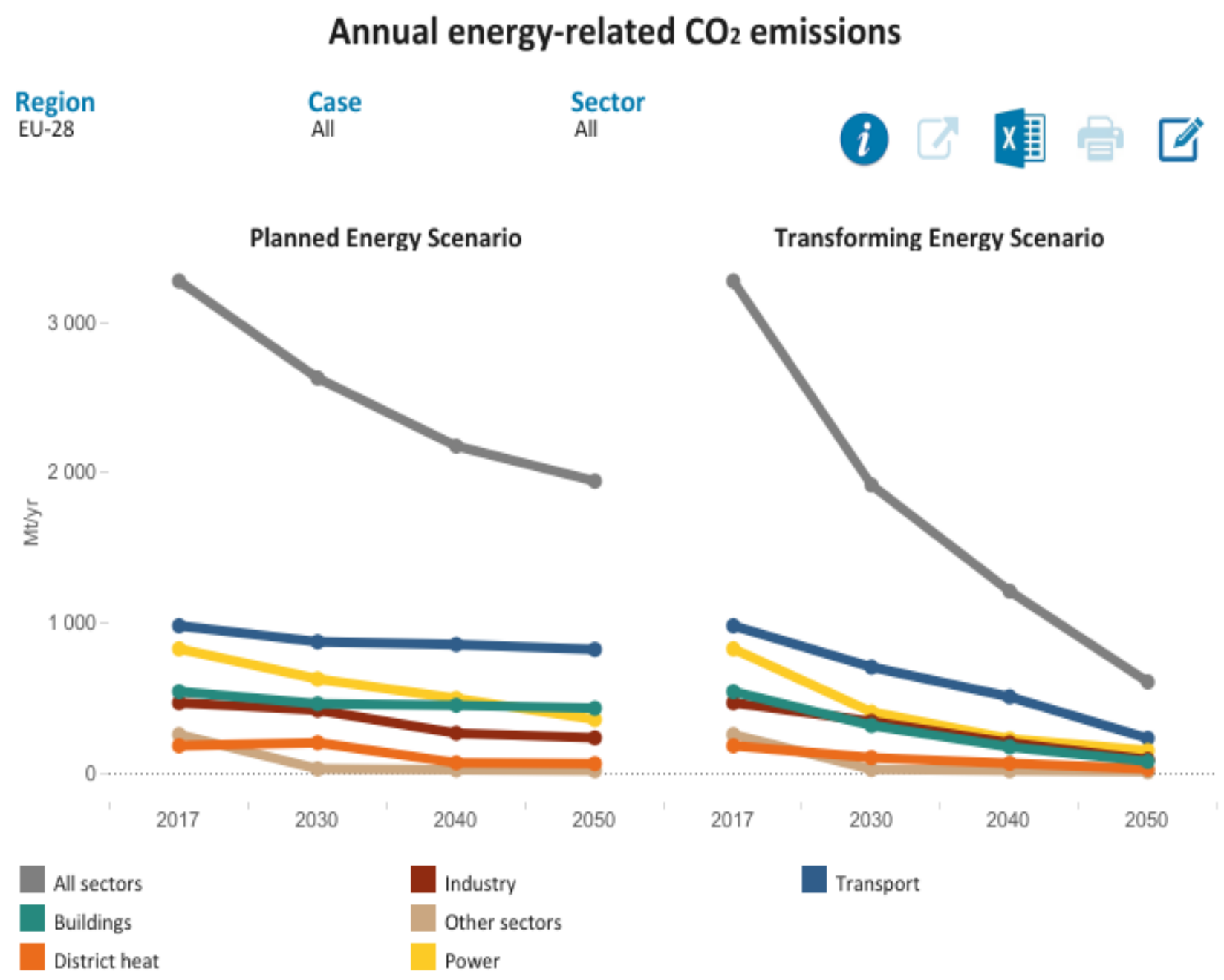

Source IRENA (2020), Global Renewables Outlook: Energy transformation 2050, International Renewable Energy Agency, Abu Dhabi https://irena.org/publications/2020/Apr/Global-Renewables-Outlook-2020.

OIRENA

Fig. 23. The annual energy-related $\mathrm{CO} 2$ emissions by sector for the reference case and REmap case by year for planned and transforming energy scenario to 2050 in EU-28

(Source: author's research results with using database IRENA)

\section{ANALYSIS OF ENERGY SECTORS OF UKRAINE AND DETERMINATION OF ADVANTAGES OF APPLICATION OF RENEWABLE ENERGY SOURCES FOR UKRAINE IN THE CONCEPT OF SUSTAINABLE DEVELOPMENT}

In Figs. $24-34$ shows the criteria for energy, economic and environmental efficiency of innovative technologies for the use of renewable energy sources in Ukraine, which analysed in order to conduct a comprehensive assessment of the effectiveness of energy and resource-saving, environmentally friendly and cost-effective innovative technologies in the concept of Sustainable Development. The results of research, shown in Figs. 24 - 34, were obtained by the author wuth using a database IRENA.

The scenario of the transformation of the energy system of the World and the European Union, analyzed in Chapter 1, in combination with an additional deeper perspective on reducing carbon dioxide emissions provides a sustainable, environmentally friendly and climate-friendly basis for 
stable long-term economic development. According to research ("IRENA", 2021), this offers the prospect of higher economic growth, cleaner living conditions and significant improving the level of well-being. This perspective will reduce global emissions carbon dioxide $\left(\mathrm{CO}_{2}\right)$ associated with energy production by $70 \%$ by 2050 . More than $90 \%$ of this reduction will be achieved through renewable energy sources and measures to increase energy efficiency. The transition to alternative energy sources can stimulate wider social economic development accompanied by integrated policies that promote transformational processes aimed at reducing carbon dioxide emissions in different countries. Such a holistic approach would lead to a reduction in carbon dioxide emissions gas related to energy production, in line with economic, environmental and social goals. According to research ("IRENA", 2021), the ultimate global climate target will be zero emissions. This perspective also looks at ways to reduce $\mathrm{CO} 2$ emissions from 2050 to zero energy balance and possibly even zero. Hydrogen and synthetic fuels, direct electrification, modern biofuels and carbon reduction measures gas will be critical along with innovative business models, structural changes and behavioral adaptation.

Fig. 24 displays information on the distribution of renewable energy technologies in Ukraine, of choice in relation to renewable energy power capacity and electricity generation figures.

\section{Renewable Energy Technologies}

$\begin{array}{lll}\text { Show by } & \text { Country/area } & \text { Year } \\ \text { Installed Capacity } & \text { Ukraine } & 2020\end{array}$

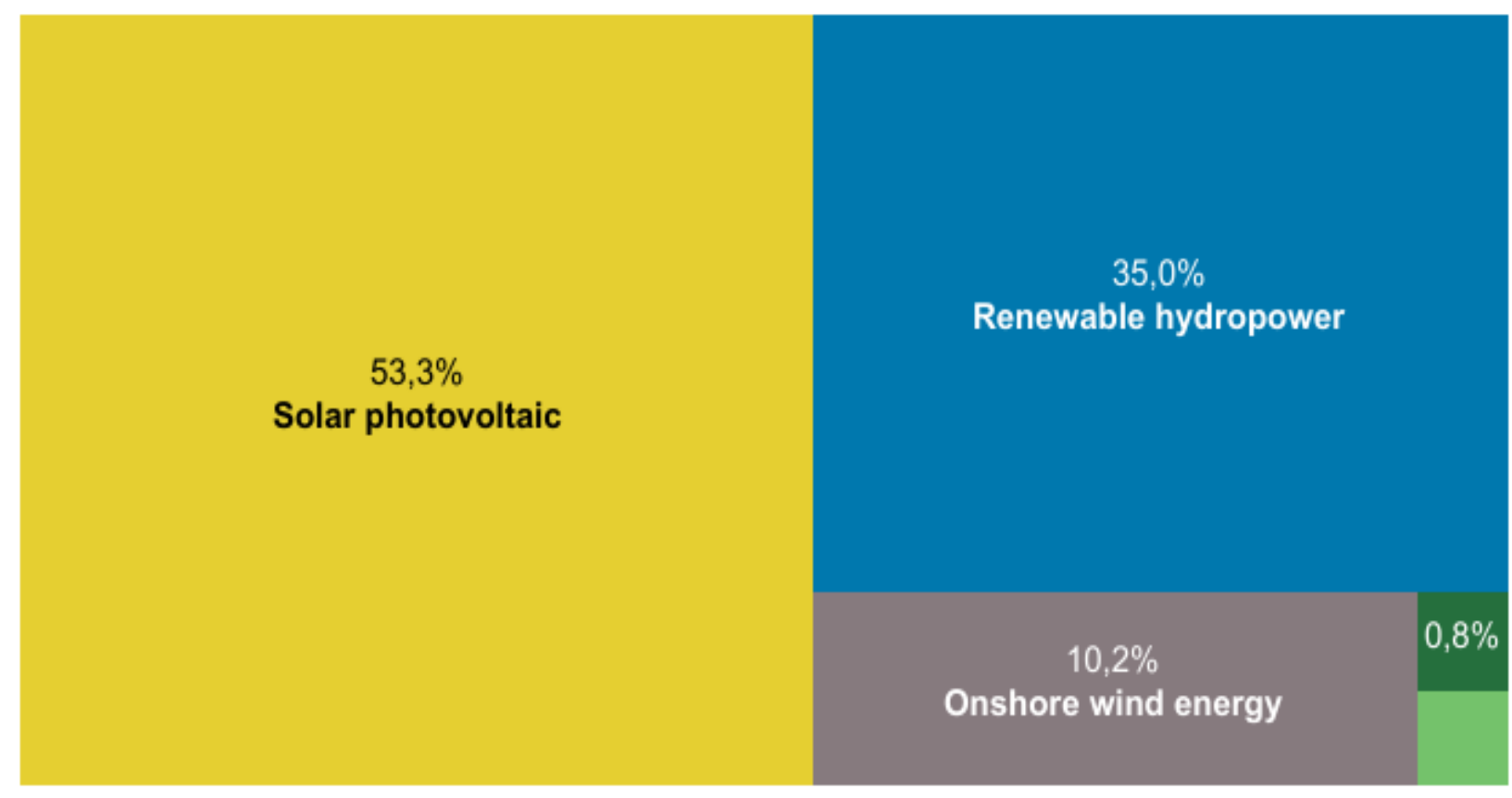

Biogas

Solar Photovoltaic

Renewable Hydropower

Onshore wind energy

Solid biofuels

Q IRENA

Fig. 24. Distribution of renewable energy technologies in Ukraine

(Source: author's research results with using database IRENA) 
Fig. 25 displays information on final renewable energy consumption in Ukraine by sector.

\section{Final Renewable Energy Consumption}

\section{Country/area
Ukraine \\ Country/area
Ukraine}

Show by
Sector

Year

2018

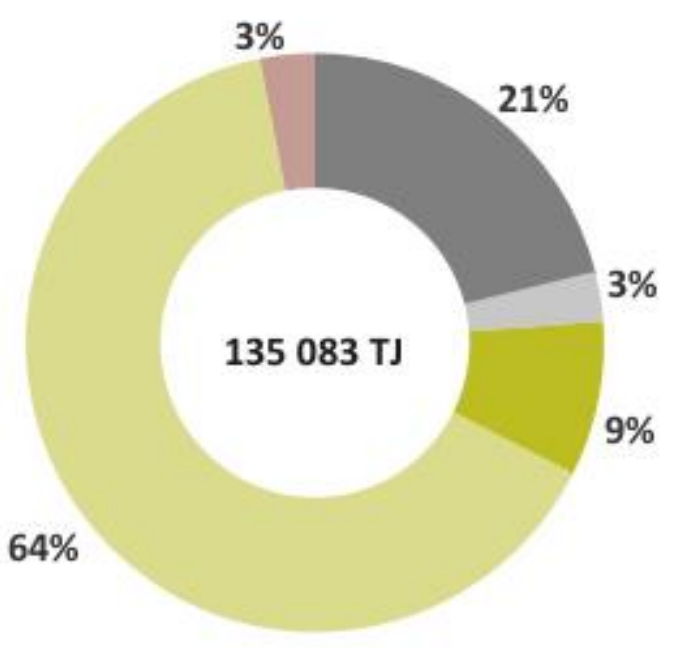

Industry

Transport

Commerical

Q IRENA

Fig. 25. Information on final renewable energy consumption in Ukraine by sector.

(Source: author's research results with using database IRENA)

Fig. 26 displays information on final renewable energy consumption in Ukraine by technology. 


\section{Final Renewable Energy Consumption}

\section{Country/area \\ Ukraine}

Hydropower

Wind

Solar Photovoltaic

Concentrated Solar Power

Solid Biofuels

\section{Show by}

Technology

\section{Year}

2018

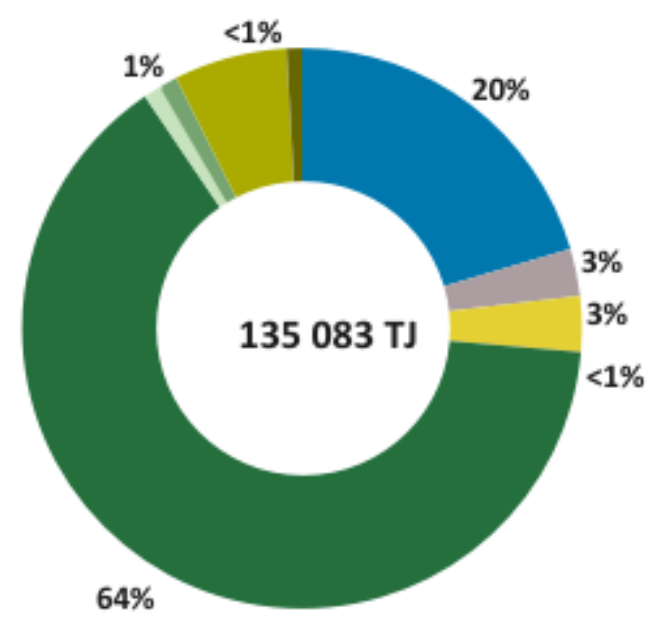
Liquid Biofuels
Biogas
Pellets
Other RE
Charcoal

o iREna

Fig. 26. Information on final renewable energy consumption in Ukraine by technology (Source: author's research results with using database IRENA)

Fig. 27 provides an overview of the total final energy consumption by sector (TFEC) by source for the reference case and REmap case by year for planned and transforming energy scenario to 2050 in Ukraine 


\section{Total Final Energy Consumption (TFEC)}

$\begin{array}{ll}\text { Country/area } & \begin{array}{l}\text { Breakdown by } \\ \text { Ukraine }\end{array} \\ \text { By Source }\end{array}$
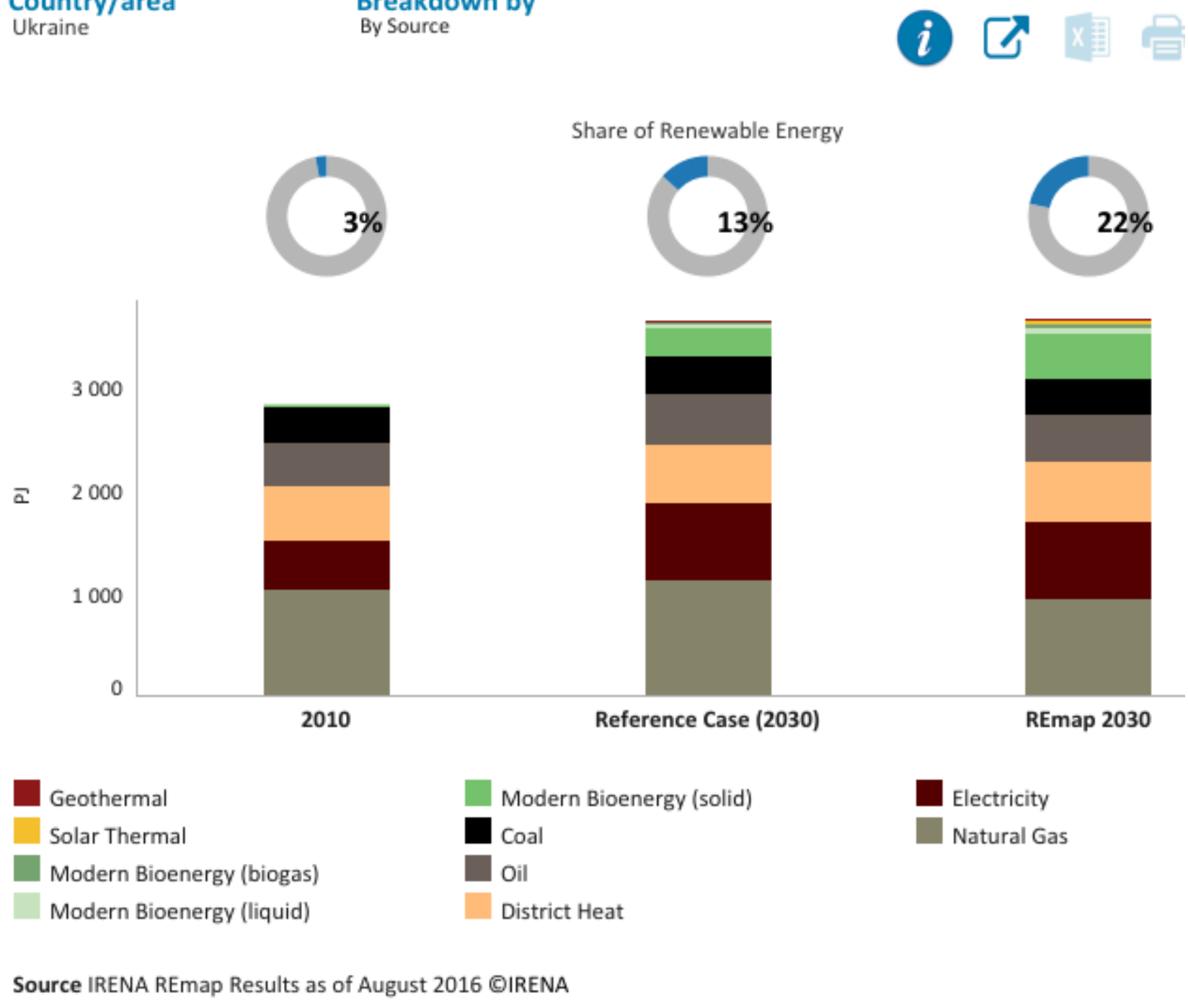

Fig. 27. The total final energy consumption by sector (TFEC) by source for the reference case and REmap case by year for planned and transforming energy scenario to 2050 in Ukraine

(Source: author's research results with using database IRENA)

Fig. 28 provides an overview of the total final energy consumption by sector (TFEC) for the reference case and REmap case by year for planned and transforming energy scenario to 2050 in Ukraine 


\section{Total Final Energy Consumption (TFEC)}

$\begin{array}{ll}\text { Country/area } & \text { Breakdown by } \\ \text { Ukraine } & \text { Direct Uses, District Heat \& } \\ & \text { Electricity }\end{array}$
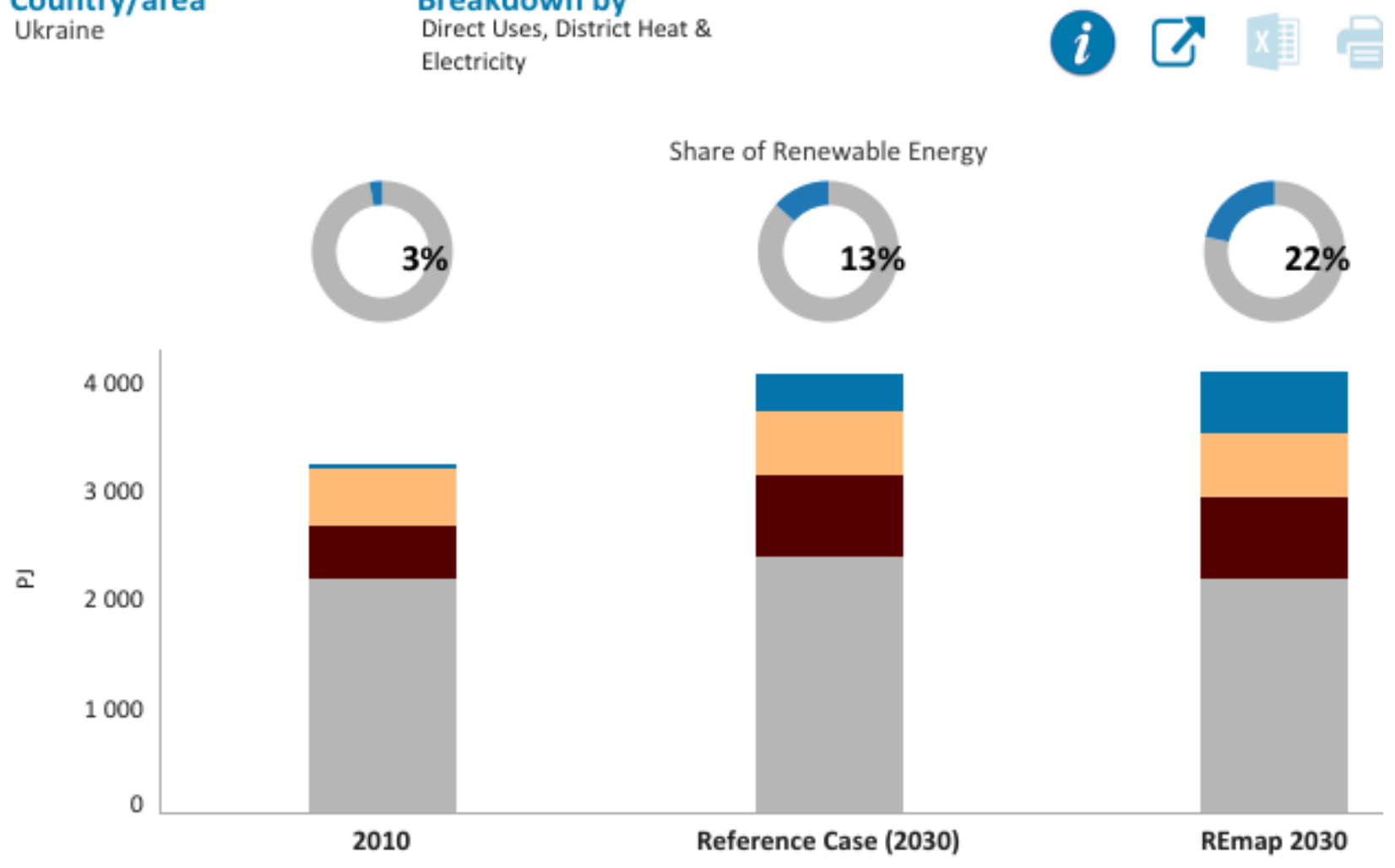

Direct Source (Renewables)

District Heat

Electricity

Direct Source (Non Renewables)

Source IRENA REmap Results as of August 2016 CIRENA

Fig. 28. The total final energy consumption by sector (TFEC) for the reference case and REmap case by year for planned and transforming energy scenario to 2050 in Ukraine

(Source: author's research results with using database IRENA)

Fig. 29 provides an overview on the renewable energy balance for Ukraine 


\section{Renewable Energy Balances by Country}

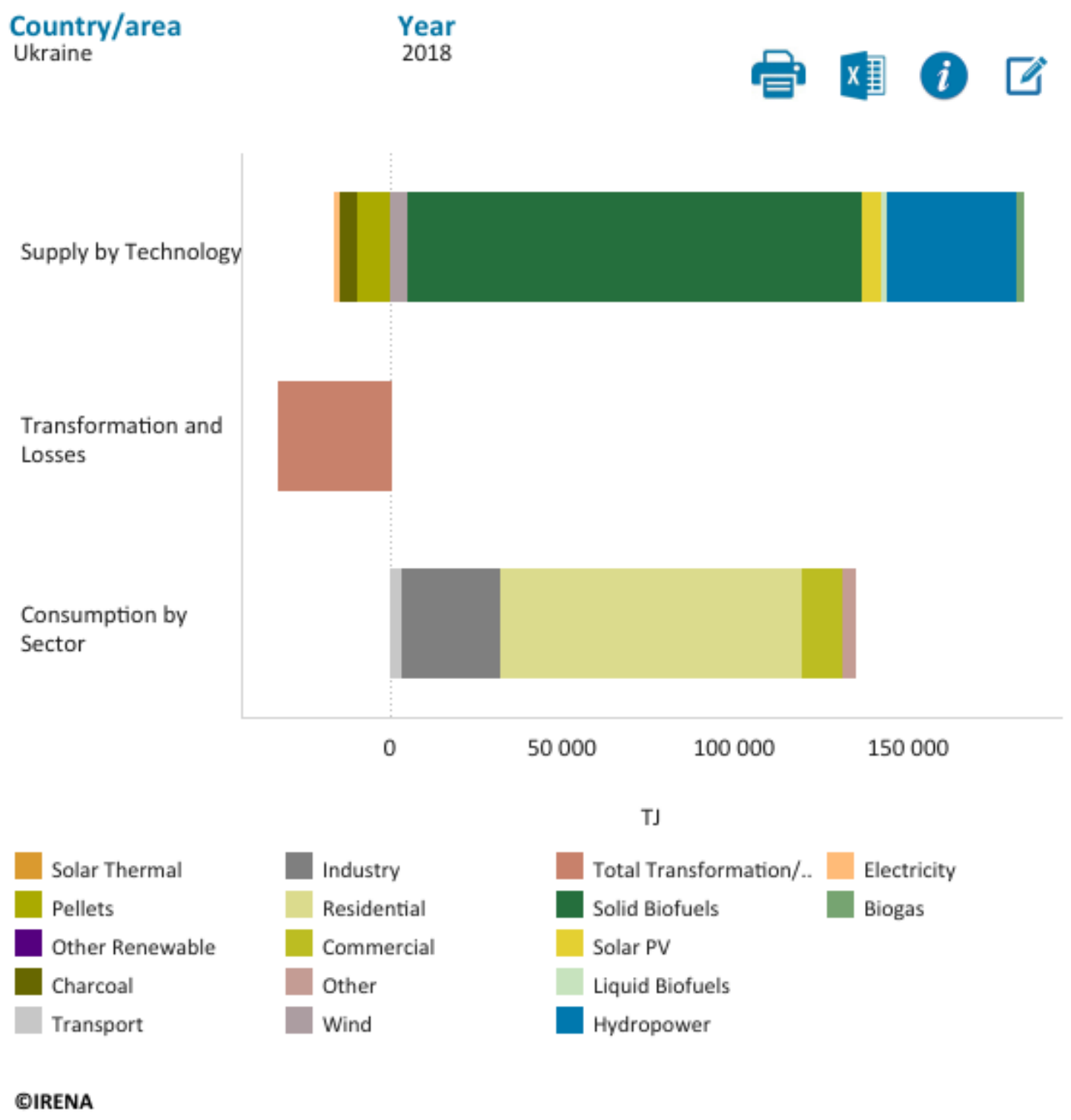

Fig. 29. The renewable energy balance for Ukraine (Source: author's research results with using database IRENA)

Figs. 30 - 34 estimates the greenhouse gas emissions avoided in Ukraine due to a renewable electricity generation in a given year compared to various fossil fuel generation scenarios 


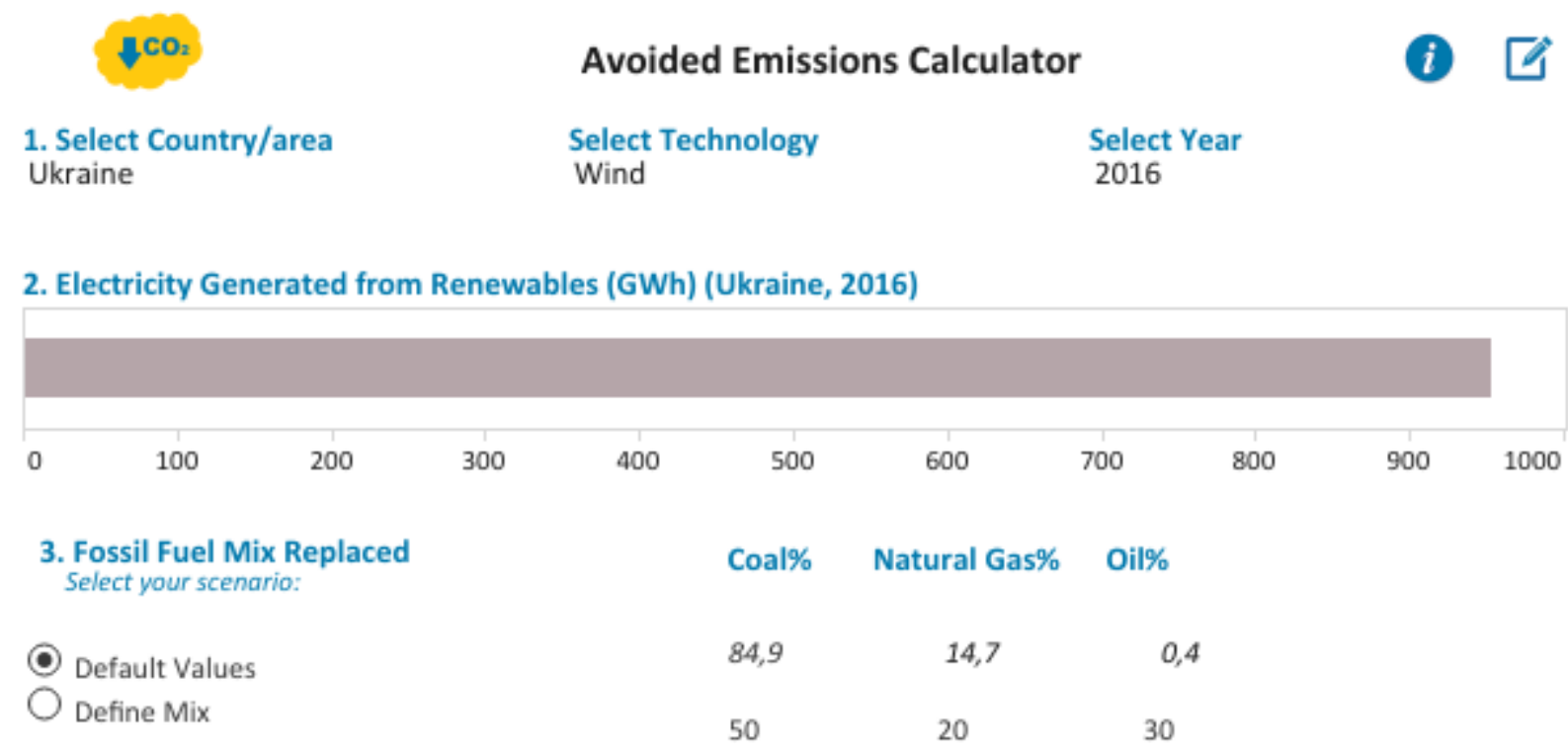

Fossil Fuel Emissions Replaced (Million Tonnes CO2e)

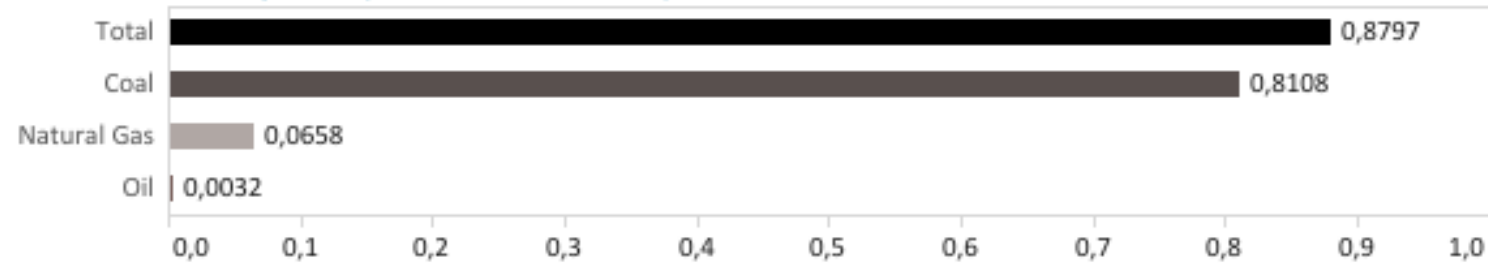

Assuming the renewable energy electricity generation in (2) replaces the fossil fuel mix generation scenario in (3), the country has avoided the following amount of emissions:

\section{Avoided Emissions \\ 0,8683 Million Tonnes CO2e}

O IRENA

Fig. 30. Greenhouse gas emissions avoided in Ukraine due to a renewable (wind) electricity generation in 2018 compared to various fossil fuel generation scenarios

(Source: author's research results with using database IRENA) 


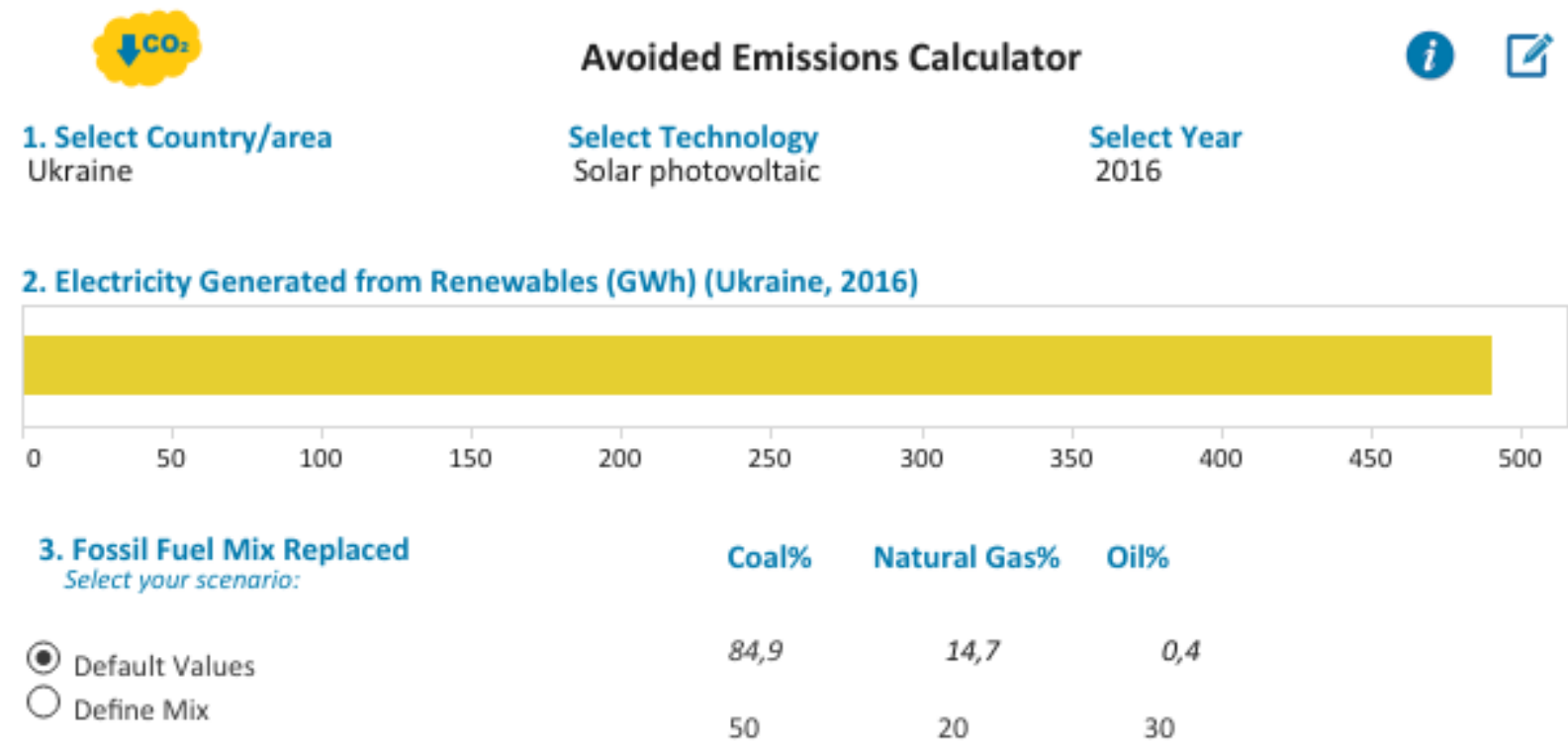

Fossil Fuel Emissions Replaced (Million Tonnes CO2e)

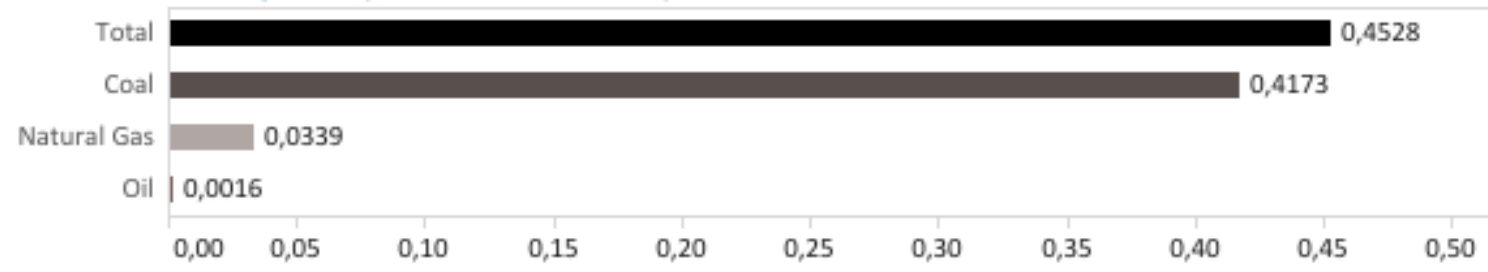

Assuming the renewable energy electricity generation in (2) replaces the fossil fuel mix generation scenario in (3), the country has avoided the following amount of emissions:

\section{Avoided Emissions \\ 0,4302 Million Tonnes CO2e}

D IRENA

Fig. 31 Greenhouse gas emissions avoided in Ukraine due to a renewable (solar photovoltaic) electricity generation in 2018 compared to various fossil fuel generation scenarios

(Source: author's research results with using database IRENA) 


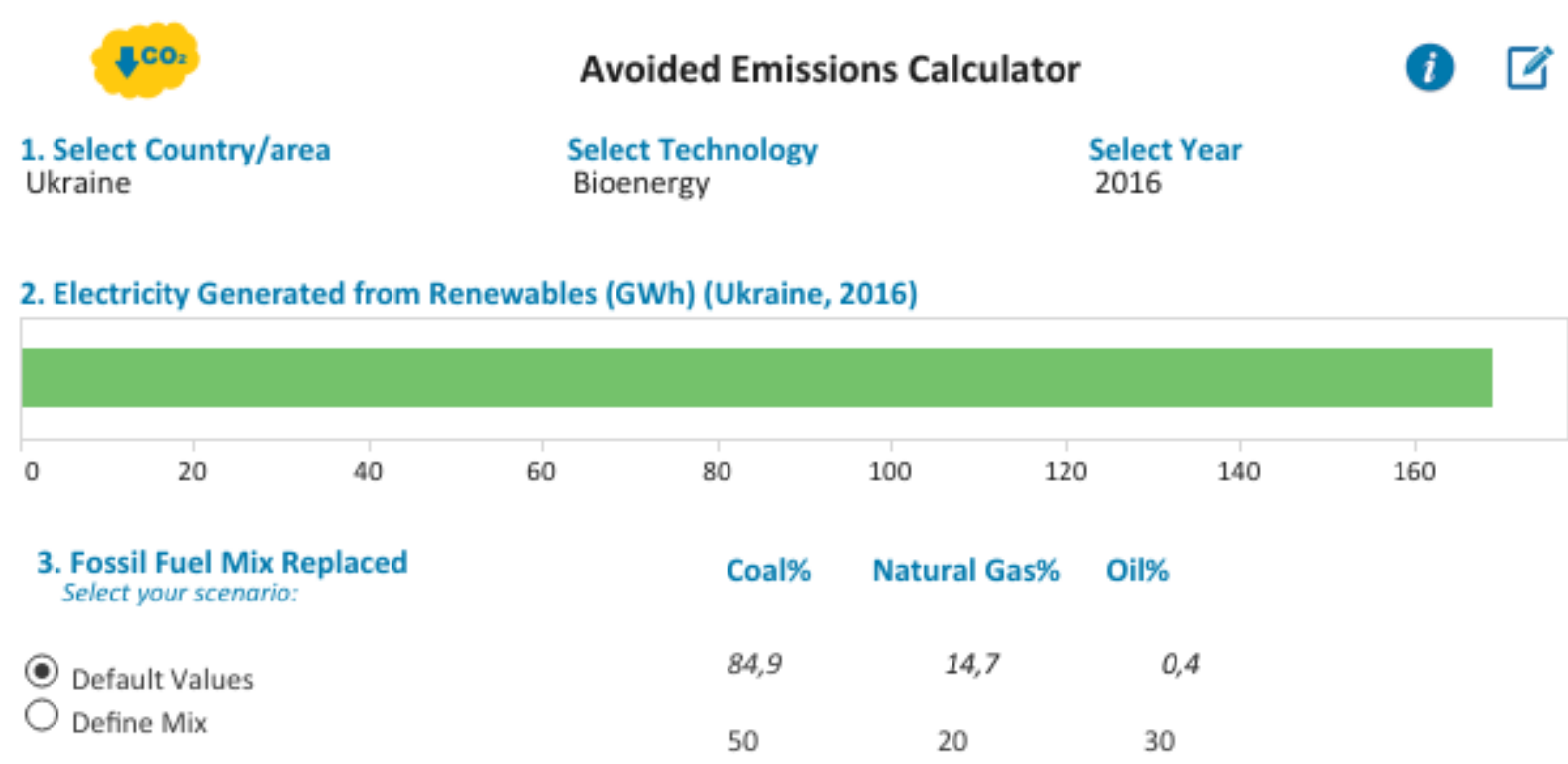

Fossil Fuel Emissions Replaced (Million Tonnes CO2e)

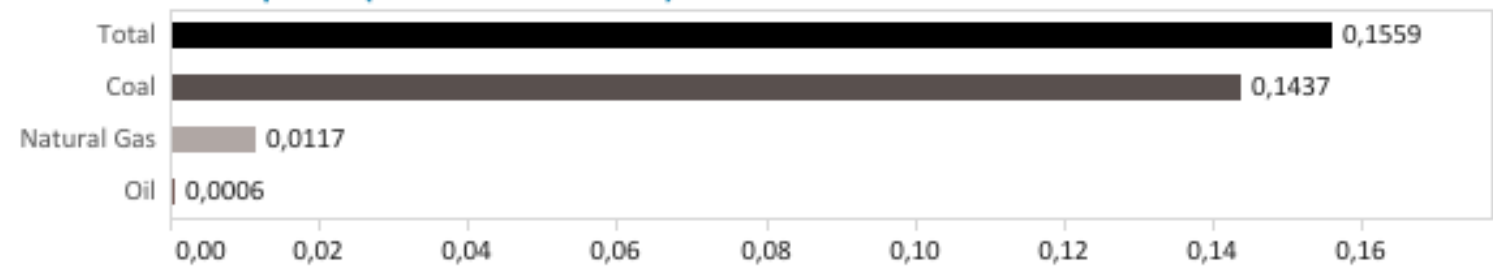

Assuming the renewable energy electricity generation in (2) replaces the fossil fuel mix generation scenario in (3), the country has avoided the following amount of emissions:

\section{Avoided Emissions \\ 0,1529 Million Tonnes CO2e}

D IRENA

Fig. 32 Greenhouse gas emissions avoided in Ukraine due to a renewable (bioenergy) electricity generation in $\mathbf{2 0 1 8}$ compared to various fossil fuel generation scenarios (Source: author's research results with using database IRENA) 


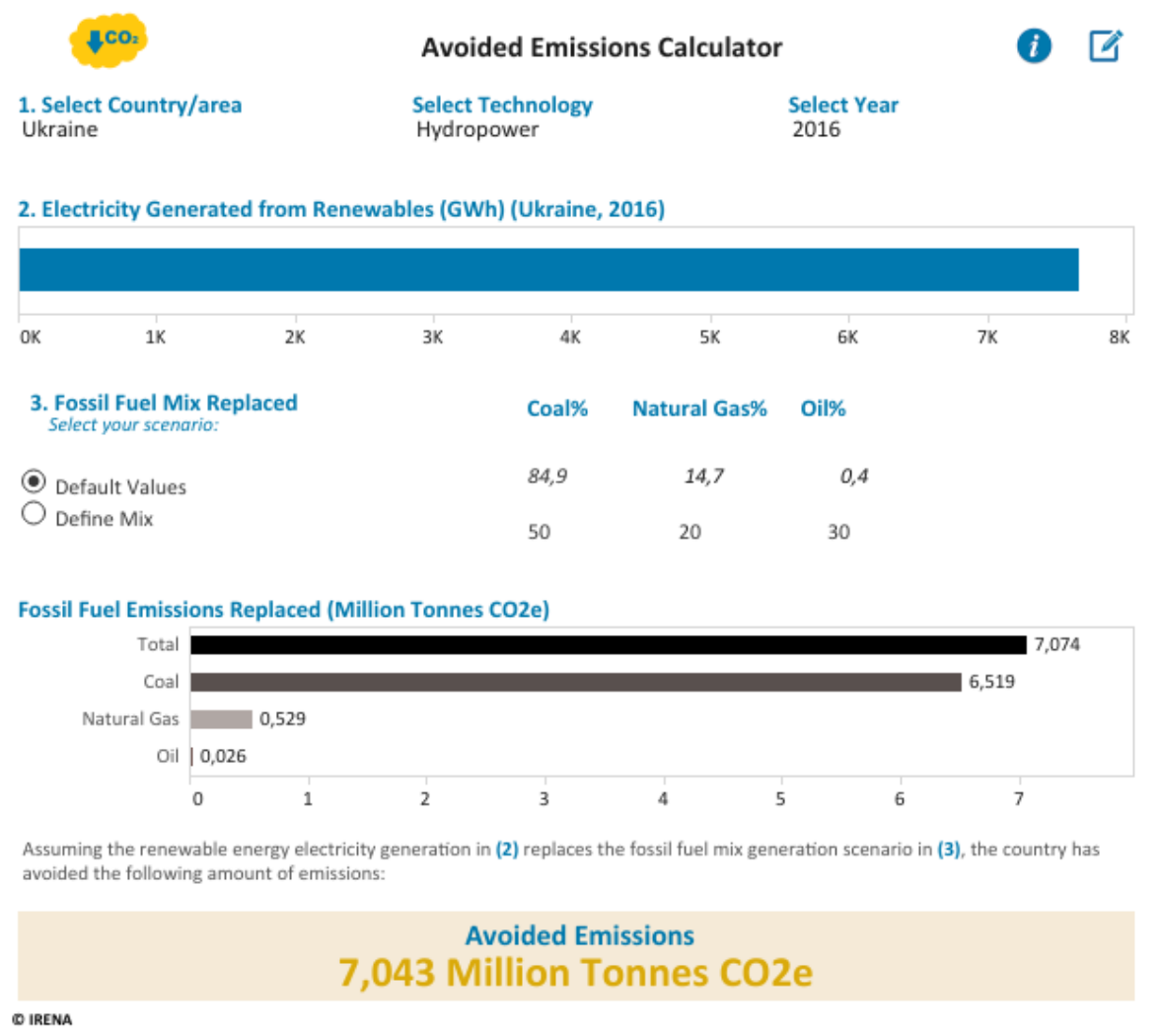

Fig. 33 Greenhouse gas emissions avoided in Ukraine due to a renewable (hydropower) electricity generation in 2018 compared to various fossil fuel generation scenarios

Source: author's research results with using database IRENA

The investigation presents an approach aimed at assessing trends in the reform of the energy sector of the world, the European Union and Ukraine in the future until 2050, using renewable energy sources in the concept of Sustainable Development.

Our research is aimed at: analysing the energy sector of the world, the European Union and Ukraine and identifying the benefits of using renewable energy sources in the concept of Sustainable Development, assessment of prospects for the application of innovative technologies based on renewable energy sources in the concept of Sustainable Development. A number of criteria for energy, economic and environmental efficiency of innovative technologies for the use of renewable energy sources are analysed in order to conduct a comprehensive assessment of the effectiveness of energy and resource-saving, environmentally friendly and cost-effective innovative technologies in the concept of Sustainable Development. 


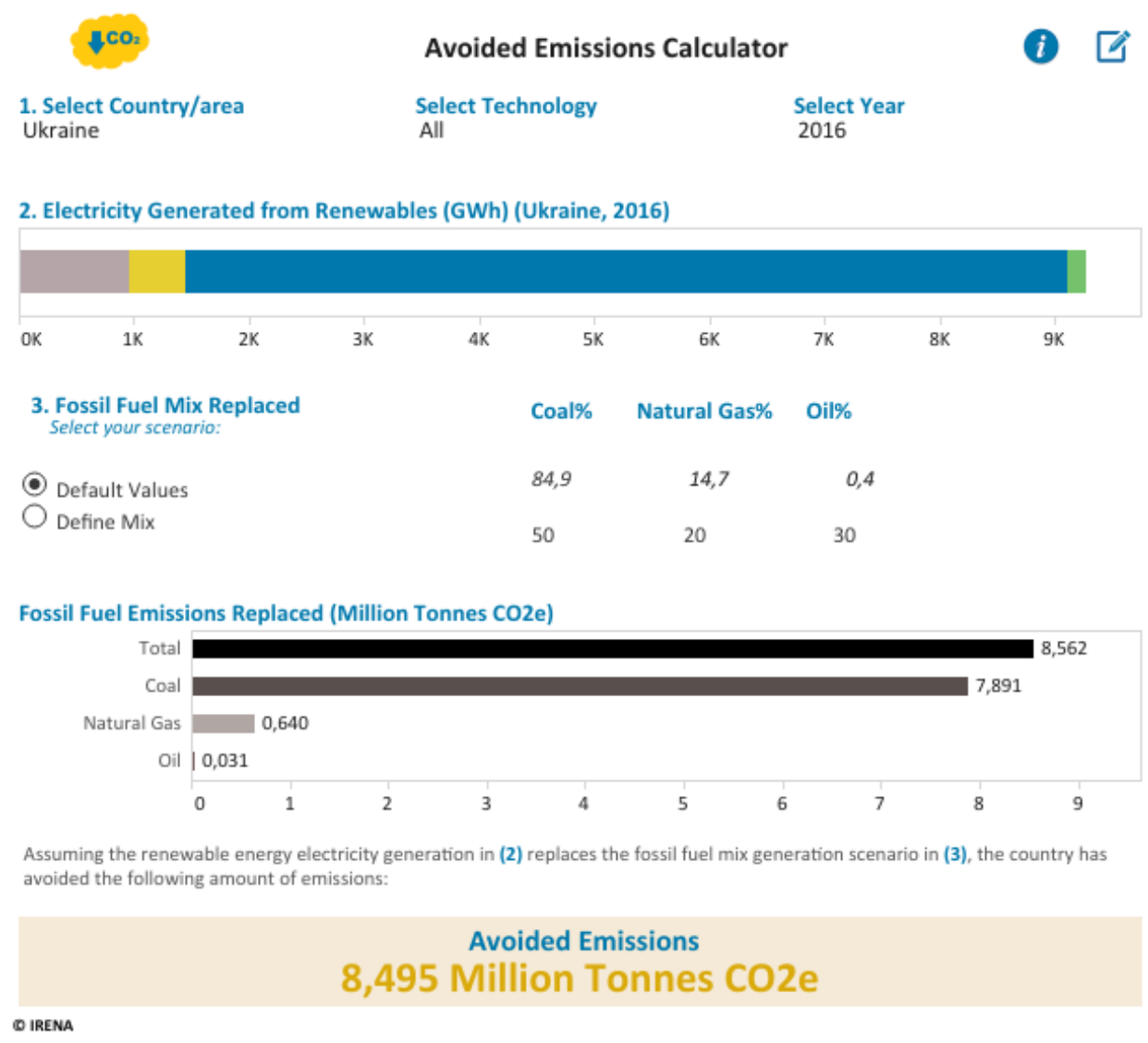

Fig. 34 Greenhouse gas emissions avoided in Ukraine due to a renewable (wind, solar photovoltaic, bioenergy and hydropower) electricity generation in 2018 compared to various fossil fuel generation scenarios CONCLUSIONS.

This approach allows providing a reasonable definition of prospects for the use of energy and resource-saving, environmentally friendly and cost-effective innovative technologies for the use of renewable energy sources in the concept of sustainable development to increase energy, economic efficiency and environmental security of Ukraine's energy sector.

The scenario of the transformation of the energy system of the World and the European Union, analyzed in Chapter 1, in combination with an additional deeper perspective on reducing carbon dioxide emissions provides a sustainable, environmentally friendly and climate-friendly basis for stable long-term economic development. According to research ("IRENA", 2021), this offers the prospect of higher economic growth, cleaner living conditions and significant improving the level of well-being. This perspective will reduce global emissions carbon dioxide (CO2) associated with energy production by $70 \%$ by 2050 . More than $90 \%$ of this reduction will be achieved through renewable energy sources and measures to increase energy efficiency. The transition to alternative energy sources can stimulate wider social economic development accompanied by integrated policies that promote transformational processes aimed at reducing carbon dioxide emissions in different countries. Such a holistic approach would lead to a reduction in carbon dioxide emissions gas related to energy production, in line with economic, environmental and social goals. According to research ("IRENA", 2021), the ultimate global climate target will be zero emissions. This perspective also looks at ways to reduce $\mathrm{CO} 2$ emissions from 2050 to zero energy balance and possibly even zero. Hydrogen and synthetic fuels, direct electrification, modern biofuels and carbon reduction measures 
gas will be critical along with innovative business models, structural changes and behavioral adaptation.

The application of the methods of sustainable development and sustainable energy in order to increase the level of energy-economic efficiency of the energy sector of Ukraine with using of renewable energy sources is presented in given paper.

The justification of the application of the methods of green logistics and sustainable development for the analysis of perspectives of application of innovative technologies is presented in the research (Ostapenko, Savina, et al, 2020).

\section{REFERENCES}

Arkhypova, L. M. et al (2021). Renewable energy resources in the system of sustainable development of Carpathian region of Ukraine. J. Phys.: Conf. Ser., 1781012010.

Brych, V. Yar., \& Fedirko, M. M. (2018). Concept of Energy Efficiency in the Context of Sustainable Development of Ukraine's Municipal Heat Engineering. Ukrainian Journal of Applied Economics, Vol. 3, 1. Retrieved from: http://ujae.tneu.edu.ua/index.php/ujae/article/view/214/212. [in Ukrainian]

Emas, R. (2015). The Concept of Sustainable Development: Definition and Defining Principles. Brief for GSDR 2015. Retrieved from: https://sustainabledevelopment.un.org/content/documents/5839GSDR\%202015_SD_concept_definiton_rev.pdf.

Foreign experience in improving energy efficiency and introducing new technologies for electricity generation. Retrieved from: https://ua.energy/wp-content/uploads/2018/01/4.Efektyvn_vyrobn_elektroenergiyi.pdf . [in Ukrainian]

IRENA (2020), Global Renewables Outlook: Energy transformation 2050. Retrieved from: https://irena.org/publications/2020/Apr/Global-Renewables-Outlook-2020.

Koval, V., Duginets, G., Plekhanova, O., Antonov, A., \& Petrova, M. (2019). On the supranational and national level of global value chain management. Entrepreneurship and Sustainability Issues, 6(4), 1922-1937. http://doi.org/10.9770/jesi.2019.6.4(27).

Koval, V., Slobodianiuk, O., \& Yankovyi, V. (2018). Production forecasting and evaluation of investments using Allen two-factor production function. Baltic Journal of Economic Studies, 4(1), 219-226. doi:10.30525/2256-0742/2018-4-1-219-226.

Koval, V., Prymush, Y., \& Popova, V. (2017). The influence of the enterprise life cycle on the efficiency of investment. Baltic Journal of Economic Studies, 3(5), 183-187. doi:10.30525/22560742/2017-3-5-183-187.

Main indicators of the fuel and energy complex of Ukraine for 2020. Retrieved from: http://mpe.kmu.gov.ua/minugol/control/publish/article?art_id= 245509476. [in Ukrainian]

Mandryk, O., Arkhypova, L., Pukish, A., Zelmanovych, A. \& Yakovlyuk, Kh. (2017). Theoretical and methodological foundations of sustainable development of Geosystems. IOP Conf. Series: Materials Science and Engineering, 200 012018. DOI: 10.1088/1757-899X/200/1/012018

Ostapenko O. P. (2020). Estimation of efficiency of energy-and resource-saving heat pump technologies in Ukraine, in the concepts of Green Logistics and Sustainable Development. Modern Approaches to Knowledge Management Development (pp. 174 -186). Ljubljana: Visoka šola za poslovne vede.

Ostapenko, O. P. (2019). Analysis of energy, ecological and economic efficiency of steam compressor heat pump installations, as compared with alternative sources of heat supply, with accounting the concept of sustainable development. Sustainable Development Under the Conditions of European Integration. Part II, (pp. 312 - 329). Ljubljana:Visoka šola za poslovne vede.

Ostapenko, O. P. (2018). Application of the method of complex assessment of energyecological-economic efficiency of energy supply systems with cogeneration heat pump installations and peak sources of heat. Science and Education a New Dimension. Natural and Technical Sciences, 171, 51 - 54. DOI: 10.31174/SEND-NT2018-171VI19-11. 
Ostapenko, O.P. (2019). Application of the methods of green logistics and sustainable development for the synthesis of highly efficient systems of energy supply with heat pumps. Knoweledge management, economics and Law: proceedings of the $1^{\text {st }}$ International Scientific conference (pp. 42 - 44). - Batumi: Publishing House «Kalmosani».

Ostapenko, O.P. (2017). Areas of high energy efficiency of energy supply systems with cogeneration heat pump installations of large power and peak fuel-fired boilers for heat supply systems. Science and Education a New Dimension. Natural and Technical Sciences, 132, 70-74.

Ostapenko, O.P. (2017). Areas of high energy efficiency of energy supply systems with cogeneration heat pump installations of small power and peak electric boilers in heat supply systems. Science and Education a New Dimension. Natural and Technical Sciences, 121, 77-80.

Ostapenko, O.P. (2017). Areas of high energy efficiency of energy supply systems with cogeneration heat pump installations of small power and peak fuel-fired boilers. Science and Education a New Dimension. Natural and Technical Sciences, 140, 64-68.

Ostapenko, O.P. (2017). Areas of high energy efficiency of energy supply systems with cogeneration heat pump installations of small power and peak electric boilers. Science and Education a New Dimension. Natural and Technical Sciences, 148, 85-89.

Ostapenko, O. P. (2020). Estimation of energy-ecological-economic efficiency of energy supply systems with cogeneration heat pump installations in Ukraine, in the concepts of green logistics and sustainable development. Institutional Development Mechanism Of The Financial System Of The National Economy: (pp. 52 - 66). Batumi: Publishing House "Kalmosani".

Ostapenko, O. P. (2016). Energy efficiency of energy supply systems, based on combined cogeneration heat pump installations and peak sources of heat. Scientific Works of Vinnytsia National Technical University, 1. Retrieved from: http://works.vntu.edu.ua/index.php/ works/article/view/462/464.

Ostapenko, O. P. (2016). Energy efficiency of energy supply systems with cogeneration heat pump installations and peak sources of heat in heat supply systems. Scientific Works of Vinnytsia National Technical University, 2. https://works.vntu.edu.ua/index.php/works/article/view/472/474.

Ostapenko, O.P. (2017). Methodical fundamentals of energy economical efficiency assessment of energy supply systems with cogeneration heat pump installations and peak sources of heat. Scientific Works of Odesa National Academy of Food Technologies, 81, 136 - 141. [in Ukrainian]

Ostapenko, O. P. (2015). Methodical fundamentals of complex assessment of energy efficiency of steam compressor heat pump plants with electric and cogeneration drive. Scientific Works of Odesa National Academy of Food Technologies, 47, 157 - 162. [in Ukrainian]

Ostapenko, O. P. (2017). Methodical fundamentals of complex assessment of energyecological-economic efficiency of energy supply systems with cogeneration heat pump installations and peak sources of heat. Scientific Works of Vinnytsia National Technical University, 3. Retrieved from: https://works.vntu.edu.ua/ index.php/works/article/view/510/509.

Ostapenko, O. P. (2018). Principles for selection of the areas of energy-ecological-economic efficiency of energy supply systems with cogeneration heat pump installations and peak sources of heat. Applied Scientific and Technical Research -2018: proceedings of the Second International Scientific and Practical conference (p. 69). - Ivano-Frankivsk: Forte Symphony.

Ostapenko, O. P. (2015). Refrigeration equipment and technology. Heat pumps. Vinnytsia: VNTU. [in Ukrainian]

Ostapenko, O. P. (2016). Scientific basis of evaluation energy efficiency of heat pump plants. Saarbrücken: LAP LAMBERT Academic Publishing.

Ostapenko, O. P. (2016). Spheres of energy efficient operation of energy supply systems with cogeneration-heat pump installations and peak sources of heat. Scientific Works of Vinnytsia National Technical University, $3 . \quad$ Retrieved from: https://works.vntu.edu.ua/index.php/works/article/view/479/481. 
Ostapenko, O. P. (2016). Spheres of high energy efficiency of energy supply systems with cogeneration heat pump installations of large power and peak fuel-fired boilers. Science and Education a New Dimension. Natural and Technical Sciences, 110, 64-67.

Ostapenko, O. P. (2017). Spheres of high energy efficiency of energy supply systems with cogeneration-heat pump installations of small power and fuel-fired boilers in heat supply systems. Scientific Works of Vinnytsia National Technical University, 1. Retrieved from: https://works.vntu.edu.ua/index.php/works/article/ view/497/499.

Ostapenko, O. P. (2019). Study of energy-economic efficiency of energy supply systems with cogeneration heat pump installations, using the heat of the industrial and natural sources, in industry and municipal heat power branch of Ukraine. Social and Legal Aspects of the Development of Civil Society Institutions Part I, (pp. 292 - 308). Warsaw: Institute of European Integration, Bmt Eridia.

Ostapenko, O. P. (2018). Substantiation of the method of complex assessment of energyecological-economic efficiency of energy supply systems with cogeneration heat pump installations and peak sources of heat. Scientific Works of Vinnytsia National Technical University, 1. Retrieved from: https://works.vntu.edu.ua/index.php/ works/article/view/526/524.

Ostapenko, O. P., Bakum, Y. V., \& Yuschishina, A. V. (2013). Energy, ecology and economy aspects of the efficiency of heat power stations operating on natural and industrial heat sources. Scientific Works of Vinnytsia National Technical University, 3. Retrieved from: https://works.vntu.edu.ua/index.php/works/article/ view/384/382.

Ostapenko, O.P., Leshchenko, V.V., \& Tikhonenko, R.O. (2015). Energy efficiency of energy supply systems, based on combined cogeneration heat pump installations. Scientific Works of Vinnytsia National Technical University, 4. Retrieved from: http://works.vntu.edu.ua/index.php/works/article/view/451/453.

Ostapenko, O. P., \& Portnov, V. M. (2018). Analysis of energy-economic efficiency of energy supply systems with cogeneration heat pump installations in industry and municipal heat power branch of Ukraine. Imperatives of Civil Society Development in Promoting National Competitiveness: proceedings of the $1^{\text {st }}$ International Scientific and Practical conference (volume I, pp. 111 - 113). Batumi: Publishing House «Kalmosani».

Ostapenko, O. P., \& Portnov, V. M. (2018). Economical aspects of the efficiency of usage of energy supply systems with cogeneration heat pump installations of various power levels. Eastern European Studies: Economics, Education and Law: proceedings of the International Scientific conference (volume II, pp. 60 - 62). - Burgas: Publishing House FLAT Ltd-Burgas.

Ostapenko, O., Savina, N., Mamatova, L., Zienina-Bilichenko, A. \& Selezneva, O. (2020). Perspectives of application of innovative resource-saving technologies in the concepts of green logistics and sustainable development. Turismo: Estudos \&Práticas (UERN), Mossoró/RN, Caderno Suplementar, 02. http://natal.uern.br/periodicos/index.php/RTEP/article/view/1261/1202.

Ostapenko, O. P. \& Shevchenko, O. V. (2011). Perspektyvy zastosuvannya teplonasosnykh stantsiy v Ukrayini. Suchasni tekhnolohiyi, materialy $i$ konstruktsiyi v budivnytstvi: naukovotekhnichnyy zbirnyk, 2, 132-139. Vinnytsia: VNTU. [in Ukrainian]

Ostapenko, O. P., Valigura, I. O., \& Kovalenko, A. D. (2013). Energy ecological efficiency of heat pumping stations, operating on natural and industrial sources of heat at variable operation modes. Scientific Works of Vinnytsia National Technical University, 2. Retrieved from: https://works.vntu.edu.ua/index.php/ works/article/view/376/374. 


\title{
CONCEPTUAL APPROACHES TO FINANCIAL RISK MANAGEMENT OF
} THE COMPANY BASED ON THE THEORY OF SUSTAINABILITY

\author{
Oleksandra Laktionova ${ }^{1}$, Iryna Sedikova ${ }^{2}$, Viktor Koval ${ }^{3}$, Sergey Radukanov ${ }^{4}$ \\ ${ }^{I}$ Vasyl' Stus Donetsk National University, Ukraine \\ 2 Odessa National Academy of Food Technologies, Ukraine \\ ${ }^{3}$ Odessa Institute of Trade and Economics of Kyiv National University of Trade and Economics, \\ Odessa, Ukraine \\ ${ }^{4}$ St. Cyril and St. Methodius University of Veliko Tarnovo, Veliko Tarnovo, Bulgaria
}

ORCID ID (D) : ${ }^{1} 0000-0001-6472-6503,{ }^{2} 0000-0003-4376-1267,{ }^{3} 0000-0003-2562-4373,{ }^{4} 0000-0002-4279-1109$

\begin{abstract}
The stochastic nature of modern economic relations, the nonstationary of the development patterns, as well as the complexity of the volatile environment for the realization of such patterns, determines the need for continuous improvement of management methods and technologies both from the standpoint of increasing the degree of their diversity through the development of tools in various fields of knowledge, and by increasing the level of systematic management impact. As a result, the problems of inclusion of uncertainty and risk as management objects have become interdisciplinary in nature. This tendency is also typical for scientific research of financial risk management problems.
\end{abstract}

\section{INTRODUCTION}

Today the issues of financial risk management are at the intersection of such scientific areas as financial stability management, financial security management, adaptive management theory, and the theory of sustainable systems. They are also a necessary component in decision-making in all areas of financial management without exception. At the same time, the theory of financial risk management has its own specific methodology, focus and tasks that cannot be solved by developing only the above areas.

In this regard, at the present stage of development, the issues of developing a management concept that determines the logic, structure, and principles of the functioning of the financial risk management system for enterprises in the non-financial sector of the economy acquire particular relevance. For enterprises of this sector of the economy, which do not have the ability to transform risks in space and time, unlike financial and credit institutions or financial market, the issues of identification the level of acceptable financial risk, the area of financial sustainability, the optimal ratio of profitability and risk, as well as the choice of an acceptable management toolkit are nontrivial and ambiguous. The solution of these issues is significantly complicated for the following reasons: the systematic methodology of financial management itself has not yet developed enough especially in the countries with developing financial markets, an underdeveloped financial intermediation system.

\section{LITERATURE REVIEW}

There is no doubt about the need to manage risks (including financial ones) on a systematic basis. Such scientists as Karen A. Horcher (2011), Ključnikov, A (2015), Bouchaud, J. P., Potters, M. (2000), Malevergne, Y., \& Sornette, D. (2006), Brooks, C., Sangiorgi, I., Hillenbrand, C., \& Money, K. (2018).

The authors support the need for further development of the study of risk management problems based on their dynamic properties, identifying their internal dialectical inconsistency, integrity as a complex, multifaceted phenomenon of human existence.

In this regard, the purpose of the article is to develop a systematic approach to the management of financial risks of an enterprise based on the formulation of the principles of the theory of sustainable systems, as well as mechanisms of management influence (Civča, Atstāja, Koval, 2021). 
The formation of a financial risk management system must be carried out on the basis of determining its main system-forming factors: functions and goals. In this case, the function is considered as the meaning of existence, purpose, necessity of the system (Erokhina, 1999). The fact that the function determines the structure, functioning and development of the system gives grounds to speak of it as the main system-forming factor (Baklanova, Petrova, Koval, 2020). The function is assigned to the system from the outside and shows what role this system plays in relation to a more general system in which it is included as a component along with other systems that act as an environment for it. So, being included in the general financial management system, the financial risk management subsystem obeys its general function - to satisfy financial interests or ensure the financial potential of the main participants of the enterprise - owners, investors, creditors, counterparties, employees and the state. Violation of this function leads to the destruction of the system - bankruptcy of the enterprise (Nazarova et al., 2020). As a result, one of the goals of the enterprise is to maintain its financial sustainability, which, at the same time, is a function of the financial risk management system (Pukala, Sira, Vavrek, 2018; Yankovyi et al., 2020). The aim of the latter is to reduce financial risks to an acceptable level. In this case, the goal is the "desired" state of its outputs, that is, some value or a subset of the values of the system functions (Afanasyev, 2000). A number of important conclusions follow from this:

1) the function is primary in relation to the goal, in connection with which the maintenance of financial sustainability is carried out within the framework of satisfying the financial interests of the main participants in the enterprise, their ratio and dominance in a specific period of time. Due to the presence of many participants and the difference in their interests at different stages of the enterprise's functioning, the state of financial sustainability cannot be described by one single and unchanging indicator. Hence, the possibility of changing the priorities and target function of financial risk management of the enterprise, its multi-criteria, changing the boundaries of the area of financial sustainability and, consequently, the acceptable level of financial risk. From our point of view, the failure to take into account this aspect is one of the reasons why the problem of defining the essence of financial sustainability has not yet been resolved - an attempt to describe financial sustainability based on one parameter is doomed to failure in advance, whether it is the constancy of the excess of income over expenses, the balance of inflows and outflows, balance of supply and demand of financial resources, solvency or any others. More justified is the definition of financial sustainability as an integral characteristic;

2) the difference in the functions of economic entities in the financial and non-financial sectors determine the difference in their goals. In particular, the goal of managing the financial risks of banks is reduced to taking risk and receiving an appropriate reward for this, thereby optimizing the ratio of risk and return (National Bank of Ukraine, 2018). In contrast, enterprises in the non-financial sector of the economy, in order to receive remuneration in the form of profit, assume not financial, but commercial risk. Financial risk is a concomitant phenomenon of the functioning of the enterprise and, therefore, in relation to this risk, managerial influence is required, aimed at reducing it to an acceptable level.

To reveal the essence of financial risk management, as well as its role in the process of adaptation of an enterprise to disturbing influences, it is necessary to clarify such concepts as stability and balance, as well as their relationship. It should be noted that the interpretation of these concepts from the standpoint of financial management differs from the understanding of these phenomena in the theory of self-organization and synergetics - scientific areas where these categories are the direct object of research (Batyrbekova, Petrova, Ussova, 2020).

\section{RESULTS}

In financial management, the concept of equilibrium is mainly considered as a synonym for "balance", which is typical for understanding equilibrium in macroeconomics. Accordingly, the equilibrium is supposed to be considered as the equality of supply and demand in the system of all resources of the enterprise. Similarly, the financial equilibrium could be mentioned as a state in which the enterprise's effective demand for funds is equal to their accepted supply at each moment in time 
in the period under review. More narrowly, this concept is considered by Kramarenko (2003), who identifies financial equilibrium with the ratio of the company's own and borrowed funds, when past and new debts are fully paid off at their own expense. In the works of French authors, financial equilibrium is considered as a balance of financial flows, taking into account all types of activities (Doszhan et al., 2020). On the basis of identifying financial equilibrium with the balance of financial resources, some authors conclude that financial equilibrium is a broader concept than financial stability.

In the theory of self-organization of the systems, sustainability and equilibrium are considered as special characteristics of the state of the parameters of the system. In particular, equilibrium is understood as the state of a closed system in which its macroscopic parameters remain unchanged, that is, the established structure, functioning, parameters of its inputs and outputs are preserved (Erokhina, 1999). Thus, in this case, the equilibrium state reflects a certain state of stationarity of the parameters of the system - a state in which the parameters of its functional invariant are constant in time and remain unchanged in the absence of disturbing influences from the external environment. In this case, the functional invariant is a subset of the parameters of the system, the interrelated change of which determines its purposeful movement. For a long time, only closed systems that have no connection with the external environment can be in a state of equilibrium, while for open systems, equilibrium can only be an instant in the process of continuous changes (Volkenstein, 1986).

More informative from the standpoint of identifying the features of the functioning of such systems is their comparison with nonequilibrium systems: for weakly equilibrium systems, small changes in the external environment make it possible for the system in new conditions to achieve a state of new equilibrium; strongly nonequilibrium systems, which are very sensitive to external influences, under the influence of external signals, even small in magnitude, can rearrange in an unpredictable manner (Mayevsky, 1994).

Thus, this characteristic can be used as the basis for determining the attribute of financial equilibrium. Accordingly, as factors of financial equilibrium, we will understand the factors of sensitivity (openness) of an enterprise to the destabilizing influence of financial risks. In the practice of banks, this characteristic is called exposure (Labunska, Petrova, Prokopishyna, 2017).).

In turn, sustainability characterizes the ability of a complex system to maintain its working state in order to achieve planned results in the presence of disturbing influences (Seitzhanov et al., 2020). This ability is a direct result of managerial influence and, accordingly, reflects the ability to neutralize the consequences of the influence carried out on it, while maintaining its own integrity and structural balance.(Pukala, 2016).

Hence, financial sustainability is a functional of three parameters:

- the magnitude of financial risk (magnitude of the disturbing effect);

- the state of the factors of financial equilibrium;

- the effectiveness of the influence action.

At the same time, the factors of financial balance, together with the enterprise's ability to regulate financial risk, form the financial potential to reduce the level of financial risk.

By analogy with the selection by the authors in the investigation of economic systems of internal, external, and inherited types of their sustainability, taking into account the above, it is advisable to distinguish the following types of financial stability:

- inherited financial sustainability, which is determined on the basis of the initial state of the factors of financial equilibrium;

- external financial sustainability, determined based on the level of external financial risks;

- the acquired financial sustainability, determined on the basis of the result of the control action.

In turn, depending on the state of the factors of financial equilibrium and the magnitude of financial risk, the following types of state of the enterprise can be distinguished:

- steady-equilibrium;

- stable-nonequilibrium;

- unstable-equilibrium; 
- unstable-nonequilibrium.

The area of sustainability is a set of values of the financial parameter at which the system is stable (Zahariev et al., 2021). The proximity of the system to the boundary of the sustainability area is estimated by the sustainability margins. In turn, the area of sustainability determines the financial risk corridor - the possible range of its changes, at which the enterprise operates in a steadily stable or quasi-stable mode. Obviously, such an area of sustainability can have only one boundary if only one of the directions is a negative change in the financial parameter - its decrease or increase.

As noted above, financial sustainability is determined by a certain set of financial parameters, which presupposes the existence of a spatio-temporal structure of critical levels of financial risks, the investigation of which is of great interest for understanding the mechanisms of destabilization. The further the state of the system as a whole and its individual parameters in area and time from the zone of critical values, the more sustainability it has, and vice versa.

Financial risk management must obey certain principles - a set of requirements for the management system, its structure, organization of management activities, management technology. The main ones include: the principle of the need to maintain sustainable development of the enterprise; the principle of optimizing the ratio of risk indicators and the level of profitability; feedback principle; the principle of the optimal balance of eco-autonomy and integrity; bottleneck principle; the principle of a portfolio approach; the principle of hierarchical management; dependence of the risk level on the forecasting horizon; efficiency; taking into account the cost of funds over time; the principle of comprehensiveness of management and inclusion of quasi-financial risks.

Looking to the sustainability of an enterprise, it is rather not a state of stagnation that is meant, but a state of sustainable development, not just the extinction of all external and internal influences, but a flexible response to them in order not exactly to prevent, but to skillfully use new circumstances, properties and relationships for self-development systems. A super-stable system, suppressing any fluctuations, preserves its structure and behavior, is not able to change qualitatively, that is, it is deprived of the possibility of development. In this regard, compliance with the principle of the need to maintain the sustainable development of an enterprise implies, when assessing the level of financial risk, the need to take into account fluctuations in a particular financial indicator, both in the direction of its decrease and increase. By maintaining a certain acceptable level of the company's openness to the influence of financial risks (a certain level of financial imbalance), the company retains a certain freedom of maneuver, as well as the possibility of making a profit if the situation develops successfully.

The reduction of the level of financial risks should be carried out within the framework of the optimization by the enterprise of the ratio of indicators of total risk and the level of profitability. This principle will improve the rationality of the decisions made in the process of financial risk management due to the fact that the consent to accept more risk will be accompanied by the possibility of obtaining more income.

In accordance with the principle of the required diversity, the diversity of the influence system should be no less than the diversity of the influenced object. In this case, diversity is understood as the number of states that the system can assume. If it is impossible to ensure internal diversity as a set of methods for effective management influence on the influence of financial risks, enterprises are forced to turn to an external mechanism for compensating for financial risk or transferring it.

To organize an effective management system, it is also required that there is an element of feedback in it. The purpose of this element is that, based on the measurement of the results obtained and their comparison with the planned ones, to develop certain recommendations for subsequent management. In addition, the feedback device allows to receive constant information about the effectiveness of the decisions made and an assessment of possible options for changing them. The feedback device should solve the following tasks: monitor the object in order to identify the changing values of its parameters; to carry out the synthesis of the control algorithm with known values of the parameters in order to ensure the required quality of the system's activity; design a regulatory action that implements the synthesized algorithm. A typical example of feedback action is changing the 
boundaries of the area of financial stability based on the actual results of the enterprise, as well as reducing the degree of uncertainty about the level of financial risks in the future.

When organizing a financial risk management system, it is also important to adhere to the principle of the optimal balance of eco-autonomy and integrity. At the same time, eco-autonomy (economic autonomy) implies the possibility of separate management of each of the many regulated financial risks in a complex (multi-circuit) system of influences from all other regulated values or from all specified (explicitly or implicitly) influences, except for one corresponding to it. And, conversely, the principle of integrity means the creation of such a system in which each element is connected with other elements, as a result of which changes made to one of the parameters of any element necessitate changes to all the others. An increase in the degree of system integrity usually contributes to its efficiency due to better unidirectionality of elements but entails an increase in the complexity of the system, which, in turn, entails an increase in the need for resources necessary for the creation and operation of a financial risk management system. The rational combination of the properties of integrity and isolation in financial risk management is aimed at combining the efficiency and flexibility of the system, limiting its complexity and required resources.

In accordance with the principle of "bottleneck" or " weak point" - the structural stability of the whole is determined by its least partial stability. Since various elements and subsystems of the planned financial risk management system have different maneuverable qualities, the problem arises of distributing disturbances between the parts of the system. In this case, elements with low maneuverability should have minimal disturbances.

In accordance with the principle of the portfolio approach, the level of financial risk of an aggregate of relatively homogeneous assets or liabilities is determined taking into account the degree of correlation (diversification) of financial risks of individual components of a given portfolio. Taking into account this feature, the company in managing financial risks can significantly reduce its costs.

Purposeful functioning and development of systems is carried out with the help of hierarchical organizational management systems. Hierarchy is a natural form of managing complex objects of various nature, which allows organizing the joint functioning of the various elements that make up these objects to achieve a common goal.

A hierarchical organization is a multi-level structure consisting of interconnected subsystems, the elements of which have the right to make decisions. Accordingly, the information structure of the considered financial risk management system should reflect the hierarchical nature of the organization. It is also necessary to take into account certain patterns of building hierarchical systems: the need to decompose the general control task into the tasks of subordinate elements; as a rule, the description of the state of the system at the upper levels is less detailed than at the lower ones, and the problems being solved contain more uncertainty and are more difficult to solve; the higher the level of management, the longer the decision-making period and the total duration of the assigned tasks.

The complexity of financial risk management presupposes, on the one hand, taking into account the interrelated influence of external financial risks on the financial stability of the enterprise, on the other hand, the need for joint use in space and time of various measures to reduce their level, as a result of which the efficiency and effectiveness of management influence increases. In addition, like any decision-making system, financial risk management must meet the following requirements: timeliness; availability of an implementation mechanism; optimality; efficiency; flexibility; execution control capabilities; profitability.

Based on the consideration of these principles, a financial risk management mechanism should be built, including: setting the task; multiple feasible alternative options for its solution - multiple ways to manage financial risks; multiple criteria for choosing methods of financial risk management (criterion of minimum costs; criterion of maximum effect; criterion for exceeding the effect over costs; criterion of marginal utility; efficiency criterion); multiple criteria for assessing financial risks; many preference methods (methods of the theory of fuzzy sets, methods of indifference curves, methods of decision trees, decomposition methods of the theory of expected utility). These 
requirements ate sated as the base of the process of managing financial risks of an enterprise, which consists of three subsystems:

1) subsystems for determining the area of financial sustainability;

2) subsystems for assessing the level of financial risks;

3) subsystems for regulating the level of financial risks.

The determination of the target parameters of financial sustainability is carried out according to the principle of the reverse planning process - starting from the assignment of the area of financial sustainability (the threshold level of risks of the target function of the state of the system) and ending with the identification of the threshold level of risks of individual financial relations of the enterprise. At the same time, the parameters of financial sustainability are indicators of threshold levels of risks, set sequentially in relation to financial interests, system-forming financial characteristics, types of activities of an enterprise, as well as types of financial relations. Thus, a kind of hierarchy of criteria for maintaining the financial sustainability of the enterprise is being formed. At the initial stage of determining the threshold level of financial risks, three blocks function:

1) setting the function of the priority of the financial interests of creditors, owners, counterparties, employees and the state;

2) setting the degree of the enterprise's tolerance to financial risks;

3) setting the confidence interval.

In turn, the confidence interval serves as the boundary that, according to the enterprise, separates "normal" fluctuations in indicators from extreme deviations. Typically, the probability of loss is set at $1 \%, 2.5 \%$ or $5 \%$ (the corresponding confidence intervals are $99 \%, 97.5 \%$ and $95 \%$ ). It should be noted that with an increase in the confidence interval, the indicator of the threshold level of risk will increase.

In this case, the function of the priority of financial interests is, in fact, the rule for constructing the function of priority of the system-forming financial characteristics - solvency, creditworthiness, profit, profitability and market value of the enterprise.

Further, the boundaries of the area of financial stability are determined from the position of maintaining the systemic financial characteristics at a safe level, as well as the acceptable level of integral risks of the systemic financial characteristics, that is, the risk level accepted by the enterprise that does not imply the implementation of regulatory management impact. Fixing this value is based on the principle of economy.

The threshold level of financial risk reflects the permissible degree of unfavorable change in a random variable, the excess of which will violate the financial stability of the enterprise. This indicator defines the boundaries of the area of financial sustainability of the enterprise.

The distribution of the threshold level of financial risk or a kind of "reserve" stock of sustainability is carried out by types of activities (operating, investment and financial), as well as types of financial relations of the enterprise, in the process of which the areas of stability are determined for specific types of financial risks (risk of reducing income; risk an increase in expenses; a risk of a decrease in cash inflows; a risk of an increase in cash outflow; a risk of a decrease in the usefulness of assets; a risk of an increase in the present (discounted) cost of attracted capital).

Such distribution can be carried out on the basis of a certain priority, which can be used as:

1) the level of actual financial risk - in this case, the "safety margin of stability" will be received by those elements of the system that are exposed to greater financial risk. The use of this principle does not have a stimulating effect;

2) the level of expected profitability of the type of activity or type of financial relations "safety margin" in the first place will receive those elements that make the greatest contribution to the overall profitability of the enterprise;

3) the amount of assets, costs, profits, etc., subject to financial risk.

A subsystem is developed that can analyze various types of financial risk in a single integrated and consistent environment. At the same time, such an integrated assessment assumes the presence in the management system of the possibility of cross-classification - decomposition and aggregation 
of the obtained analytical results according to given analytical sections: types of financial relations, types of activities, systemic financial characteristics and types of financial interests. The use of crossclassification makes it possible to see a complete picture of the risk and positions of the enterprise, to determine the area of dominance.

The initial data for such an assessment is the magnitude of the range of disturbing effects from external financial risks, manifested in various types of financial relations. In this case, the range of the disturbing effect is assessed on the basis of calculating the indicator of the marginal level of financial risks - a value that will not be exceeded by losses with a certain degree of probability.

Depending on the state of the factors of financial equilibrium inherent in different levels of the hierarchy indicated above, the level of diversification of financial risks, and also by comparing the obtained values of the marginal levels of financial risk, with the specified boundaries of the area of financial stability, the need to regulate their value is assessed.

Based on the control of actual results, obtaining additional information about changes in the predicted level of financial risk, adaptation of both the subsystem for regulating the level of financial risks and the assessment subsystems is carried out.

Thus, the management of financial risks in an enterprise is reduced to solving the following tasks:

- assessment of the range of disturbing effects of financial risks;

- assessment of the financial potential of the enterprise for the implementation of effective financial risk management;

- management of the factors of financial equilibrium in order to reduce the degree of vulnerability of the enterprise to the influence of financial risks;

- compensation for the consequences of the influence of financial risks.

The set tasks are intended to solve a set of mechanisms for managing the financial risks of an enterprise, including a mechanism for assessing financial risks, a mechanism for managing financial equilibrium factors and a mechanism for compensating for the effects of financial risks.

\section{CONLUSIONS}

Hence, financial risk management is a complex of interrelated mechanisms, the effective action of which is aimed at reducing the likelihood and size of possible damage or eliminating the consequences of the onset of risk events, as a result of which the financial stability of the enterprise is maintained and the financial interests of its participants are observed. The implementation of an integrated, systemic financial risk management will allow, on the one hand, to optimize the managerial impact on the source of a particular type of financial risk, on the other hand, will reduce the cost of compensating for the consequences by taking into account the possible diversification of the impact of these risks on the final financial results of the enterprise.

\section{REFERENCES:}

Afanasyev, V.G. (2000). Systematic and society. M.: UNITY-DANA.

Baklanova, O., Petrova, M., Koval, V. (2020). Institutional Transmission in Economic Development. Ikonomicheski Izsledvania, 29(1), 68-91.

Batyrbekova, M., Petrova, M., \& Ussova, I. (2020). Compositional modeling of assessment of the impact of digital strategy. Journal of Security \& Sustainability Issues, 10(2).

Belás, J., Ključnikov, A., Vojtovič, S., Sobeková-Májková, M. (2015), Approach of the SME Entrepreneurs to Financial Risk Management in Relation to Gender and Level of Education, Economics and Sociology, 8, 32-42.

Bouchaud, J. P., \& Potters, M. (2000). Theory of financial risks (Vol. 4). From Statistical Physics to Risk Management: Cambridge University Press, Cambridge.

Brooks, C., Sangiorgi, I., Hillenbrand, C., \& Money, K. (2018). Why are older investors less willing to take financial risks?. International Review of Financial Analysis, 56, 52-72.

Civča, D., Atstāja, D., Koval, V. (2021). Business continuity plan testing methods in an international company. Knowledge management competence for achieving competitive advantage of 
professional growth and development (p. 341-365). Riga, Latvia: BA School of Business and Finance. http://doi.org/10.5281/zenodo.4454180

Doszhan, R., Nurmaganbetova, A., Pukala, R., Yessenova, G., Omar, S., \& Sabidullina, A. (2020). New challenges in the financial management under the influence of financial technology. In E3S Web of Conferences (Vol. 159, p. 04015). EDP Sciences.

Erokhina, E.A. (1999). The theory of economic development: a system-self-organizing approach. Tomsk: Publishing house of Vol. University.

Gryshova, I., Petrova, M., Tepavicharova, M., Diachenko, A. P., \& Gutsul, T. (2019). A model for selection of a management team to ensure the sustainability and development of the business organizations. Entrepreneurship and Sustainability issues, 7(1), 690.

Horcher, K. A. (2011). Essentials of financial risk management. John Wiley \& Sons.

Ishchuk, S., Sozanskyy, L., \& Pukała, R. (2020). Optimisation of the relationship between structural parameters of the processing industry as a way to increase its efficiency. Engineering Management in Production and Services, 12(2).

Koval, V. Pukała, R. (2017). Implementation of Regulatory Policy in Economic Activity: Development of the Institute Regulatory Impact Assessment. Economics. Ecology. Socium, 1,24-32

Kramarenko, G.O. (2003). Financial analysis and planning. Kiev: Center for Naval Literature.

Kvach, Y., Piatka, N., \& Koval, V. (2020). Management of sustainable entrepreneurship adaptation to tax changes in environmental investment. Baltic Journal of Economic Studies, 6(5), 96105. https://doi.org/10.30525/2256-0742/2020-6-5-96-105

Labunska, S., Petrova, M., \& Prokopishyna, O. (2017). Asset and cost management for innovation activity. Economic annals-XXI, (165), 13-18.

Malevergne, Y., \& Sornette, D. (2006). Extreme financial risks: From dependence to risk management. Springer Science \& Business Media.

Marinov, M., Todorova, L. (2020). Effects of the COVID - 19 Impact on the Tourism Sector in Bulgaria. Izvestia Journal of the Union of Scientists - Varna. Economic Sciences Series, 9(2), pp.6875. DOI: https://doi.org/10.36997/IJUSV-ESS/2020.9.2.68

Mayevsky, V.I. (1994). Economic evolution and economic genetics. Problems of Economics, $5,12-23$

Mitkov, M. (2019). Status and trends in the development of the macroeconomic indicators "insurance density" and "insurance penetration" in Bulgaria and the countries of Central and Eastern Europe (1997-2017), Economic Thought journal, Bulgarian Academy of Sciences - Economic Research Institute, 3, 94-102.

Mitkov, M. (2018A). Status and Trends in the Development of Macroeconomic Indicators "Insurance Penetration" and "Insurance Density" in Bulgaria (1997-2016). Socio-Economic Analysis, 10(1), p.34-44 (2018).

Mitkov, M. (2018B). Trends in the development of the insurance market in Bulgaria, Lithuania and Ukraine in the context of global instability (2008-2016), International Security in the Frame of Modern Global Challenges: Collection of Scientific Works / Mykolas Romeris University, Kyiv National Economic University named after Vadym Hetman, pp.120-127

Mitkov, M. (2017). Development of the insurance market before and after the financial and economic integration of Bulgaria into the European Union / 1997- 1996 /, Svishtov, 9-10 November, 112-122.

Mitkov, M. (2016). Trends in investments of insurance companies in Bulgaria for period 20102015, Collection of articles and theses of the communications presented within the International Scientific Conference dedicated to the 25th anniversary since the founding of AESM "Role of investments in the development of digital economy in the context of financial globalization", December 22-23, 2016. - $\quad$ Chişinău $\quad$ : $\quad$ ASEM, 2017. http://irek.ase.md:8080/xmlui/handle/123456789/401

Mitkov, M. (2018C). Models for building a management structure in insurance. Procedings V MNPK "Management sciences in the modern world" Issues of improving anti-crisis management, 2018, pp.2-7 
National Bank of Ukraine (2018). The Regulation on the Organization of the System and Management of Risks in the Banks of Ukraine and Banking Groups" was approved by the Resolution of the Board of the National Bank of Ukraine dated 11th October 2018 to the Rock N 64 Nazarova, K., Mysiuk, V., Gordopolov, V., Koval, V., \& Danilevičienė, I. (2020). Preventional audit: implementation of SOX control to prevent fraud. Business: Theory and Practice, 21(1), 293-301. https://doi.org/10.3846/btp.2020.11647

Nazarova, K., Hordopolov, V., Kopotiienko, T., Miniailo, V., Koval, V., \& Diachenko, Y. (2019). Audit in the state economic security system. Management Theory and Studies for Rural Business and Infrastructure Development, 41(3), 419-430.

Odinokova, T., Bozhinova, M., \& Petrova, M. (2018). Promotion of innovative entrepreneurship under sustainable development. In E3S Web of Conferences (Vol. 41, p. 04015). EDP Sciences.

Petrova, M., Koval, V., Tepavicharova, M., Zerkal, A., Radchenko, A., \& Bondarchuk, N. (2020). The interaction between the human resources motivation and the commitment to the organization. Journal of Security and Sustainability Issues, 9(3), 897-907. https://doi.org/10.9770/jssi.2020.9.3(15)

Pukala, R., Sira, E., \& Vavrek, R. (2018). Risk management and financing among start-ups. Marketing and Management of Innovations, 3, 153-161. http://doi.org/10.21272/mmi.2018.3-13

Pukala, R., \& Petrova, M. (2019). Application of the AHP method to select an optimal source of financing innovation in the mining sector. In E3S Web of Conferences (Vol. 105, p. 04034). Pukała, R., Vnukova, N., Achkasova, S., \& Smoliak, V. (2017). Improvement of the methodology for assessing the capital adequacy to cover the reinsurance default risk. Economic annals-XXI, (165), 152-156.

Pukala, R. 2016. Use of neural networks in risk assessment and optimization of insurance cover in innovative enterprises, Economics and Management, Volume 8, Issue 3, p.43-56.

Seitzhanov, S., Kurmanov, N., Petrova, M., Aliyev, U., \& Aidargaliyeva, N. (2020). Stimulation of entrepreneurs' innovative activity: evidence from Kazakhstan. Entrepreneurship and Sustainability issues, 7(4), 2615.

Tamosiuniene, R., Demianchuk, M., Koval, V. (2019). State Regulation of Bankruptcy Relations in the National Economy. Economics. Ecology. Socium, 3 (4), 19-27.

Uteubayev, T., Petrova, M., \& Lyubenova, I. (2018, September). Training of Qualified Specialists in The Process of Their Education in University: The Role of The Public-Private Partnership. In CBU international conference proceedings (Vol. 6, pp. 491-495).

Volkenstein, M.V. (1986). Entropy and information. M.: Nauka.

Yankovyi O., Koval V., Trokhymets O., Karpenko M., Matskevich Y. (2020). Economic assessment of investment on the basis of production functions. Turismo: Estudos \&Práticas, 2.

Zahariev, A., Radulova, A., Aleksandrova, A., \& Petrova, M. (2021). Fiscal sustainability and fiscal risk in the EU: forecasts and challenges in terms of COVID-19. Entrepreneurship and Sustainability Issues, 8(3), 618. 


\title{
RELEVANT INTERRELATIONSHIPS BETWEEN SCIENCE AND MASS COMMUNICATION
}

\author{
Oksana Kosiuk ${ }^{1}$

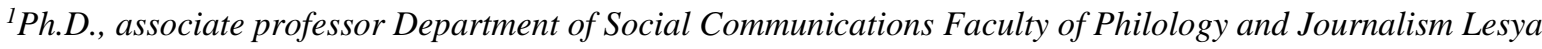 \\ Ukrainka Eastern European National University, Lutsk, Ukrain \\ ORCID ID ID: 0000-0001-8093-1961
}

\begin{abstract}
In the context of pandemic media audience focus their attention on scientific information. Therefore, studying this issue, we aimed to analyze modern mass communication activities as a historical phenomenon and compare it with scientific. With this objective we have researched database sources, explored web-sites of foreign and Ukrainian media, compared their subject areas, identified ways of communicating and covering scientific information, compared genre opportunities and considered the Covid-19 pandemic on a larger media-scientific scale. It has been defined that mass communication in its basic parameters is almost literal equivalent of popular level of scientific activity, so its problems and achievements are also associated with rational solution of global crises of civilization and culture.
\end{abstract}

\section{INTRODUCTION}

According to authors of "Mass communication in Media" publication, "mass media specialization, known as science journalism, began to develop in the United States in the 1950s and in Europe in the 1970s, and was penetrated by the idea that media function was to communicate scientific information as accurately as possible. Adequate scientific information communication was influenced by the fact that many specialists had come to journalism with basic education in natural sciences. Consequently, science journalism was formed within journalism itself, and penetrated into various media spheres in the form of scientific reports, where it began to dominate due to general journalism understanding as independent essential activity demanded by society" (Boyko, 2009, p. 19).

\section{LITERATURE REVIEW}

According to our assumptions, mass science communication / journalism seems to have been initiated by famous rationalist Gottfried Wilhelm Leibniz, who published "Acta Eruditiorum" during the Enlightenment (Kotova, 1997). Back in the seventeenth century, mathematicians, philosophers, lawyers, and publishers could acquaint mass audience with scientific events, technical innovations, abstracts of scientific works, and phenomena reviews of scientific and technological progress. Cutting-edge scientists - creators of classical theories of rationalism, empiricism, sensualism, fideism - were involved in this work. We even inclined to consider science and mass communication, in the form of journalism, being phenomena of one paradigm, but obviously of different levels. Until the Enlightenment, they had been developing in parallel, and later started "intersecting" and "overlapping" each other.

Nowadays, science journalism is functioning in different formats: as science and popular science publications, columns in universal media, blogs, information repositories, hosting classifiers, etc. According to researchers, the main problem of science journalism is - absence of qualified staff. In the context of suggested concept (Kosyuk, 2016), this problem is unsubstantiated, because journalists must absolutely and completely rely on experts' opinion, and only afterwards consider other participants' testimony and impressions during communication process. But, of course, the more erudite a journalist is, the more productive his activity will be.

In this way, our vision of journalism is different from the post-Soviet view: mass media activity is not superficial, relaxing, spectacular, etc., but - on the contrary - extremely radiocentric. 
Moreover, according to interpretations of Descartes, Spinoza, Leibniz, Malbransch, and others, journalism emergence - is organic demand for classical rationalism development. (Kosyuk, 2018).

\section{SCIENTIFIC INFORMATION IN THE MEDIA DURING A COVID-19 PANDEMIC}

Science and journalism principles are also universal: using proven facts, reliable sources and expertise; lack of emotions, and hence simplifications and dramatizations; using exclusively proven explanations, theories, strategies. And also (already familiar): freedom of expression (when you base on facts, it is necessary to distance yourself from subjective judgments and expected conclusions); public's right to receive full information disclosure (especially if recipients' health depends on it); only legitimate methods of working with arguments and facts (including those that contain confidential information); necessity for immediate refutation of accidental errors; the right not to disclose personal sources of information (unless provided by law); proper practical evaluation of theories discriminating people by sexual orientation, language, race, religion, nationality and especially - political views; avoiding compilations and plagiarism; delicate handling legal facts, which misrepresentation might fatally affect suspects' fate; careful attitude to private life of low profile figures; clear delineation of facts, comments, advertising; balance of expert opinions (including all available opposition views); respect the rights of journalists and experts.

Journalists receive information for publication from scientists' press releases, reports of research institutions and universities, materials from publications and audiovisualizations of scientific communities, subscriptions to electronic resources, encyclopedias, monographs, classic verbal media. Scientific reporters, commentators and editors include the following activity - selection of publications for specialized periodicals with narrow, almost caste, readers; production of scientific columns in non-specialized media; universal journalism, which more often covers scientific areas, but, as we have already noted, is similar to scientific activity itself.

The aim of our paper - is to focus on universal verbal journalism, because, according to our assumptions, it is an organic reproduction of scientific activity at comprehensible level (it differs from popular science literature only in genre variability, research depth and production volume) and to prove by concrete examples ("Nature", "NewScientist", "Mirror of the Week", "Correspondent") that modern journalism not only reproduces scientific achievements, but also uses principles, functions, technologies and strategies of science.

Problems of scientific aspects of journalism were studied by N. Zelinska (2009), V. Rizun (2009), A. Boyko (2009), O. Konovets (2009), V. Tereshchenko (1990), N. Bonitz (1987), S. Kuleshov (1995) (Boyko, 2009). Scientists have focused their attention on science journalism. We will try to identify science and universal media activity and consider them in the context of covering the Covid-19 pandemic.

The main method of our research is analogy. Not only scientific and media discourses are compared, but also ways of information content of Ukrainian and foreign media, chronotypes of scientificity, genres, etc. No less important was the content analysis - statistical technique for quantitative description of communication content and drawing conclusions based on systematic establishing characteristics of genrology structural units. Modeling method could not have been omitted, because the highlight of today - the pandemic, as well as objects of our research - science and journalism - are constantly developing.

Among the most rated non-specialized online media accredited abroad are BBC websites, NewScientist, Nature, and in Ukraine there are newspapers "2000", "Mirror of the Week", news website "Correspondent", etc. The oldest periodical about science - "Nature" (journal of nature research). This British popular science media, which has been published in English since 1869, in 2018 received a numerical citation rate / impact factor of 43070, which, by the way, has not often been available even to serious specialized science media.

At the beginning of the issue from 17.06.2020 (Nature. "Collections", 2020) there are three sections: "Explore content", "Publish with us", "Subscribe". Then there is an editorial entitled "Why children avoid the worst coronavirus complications", the key idea of which is: immunity factors and 
absence of complications - healthy blood vessels. Further there are different materials: "Pluto probe offers eye-popping view of neighbouring star Proxima Centauri" (news), "How BlackinThelvory emphasizes racism in academic community" (news), "Observation of Bose-Einstein condensates in an Earth-orbiting research lab" (article), "Daily briefing: Universe's coolest lab creates bizarre quantum matter in space" (a briefing on nature). Advertising "reduces" serious content and invites you to subscribe to publications.

Vertical journal sections. Its first block "News\&Comment" offers breaking news: "Latin American scientists join the coronavirus vaccine race: 'No one's coming to rescue us" (in the center there is a photo with five coffins in one grave, which is signed below: "Brazil currently has the second highest number of confirmed COVID-19 cases in the world." This publication is marked as news. The following two blocks include other material: "Coronavirus research update: modified mice can help find vaccines and drugs" (news), "Hong Kong's contentious national security law concerns some academics" (news), "Lab-grown cells mimic crucial moment in embryo development" (news), "Borrow crisis tactics to get COVID-19 supplies to where they are needed" (comment), "Pluto probe offers eye-popping view of neighbouring star Proxima Centauri" (news), as we remember this material has already been published in breaking news block.

Next vertical section "Latest Reviews \& Analysis" is presented by editorial in oncology area "Neutrophil 'safety net' causes cancer cells to metastasize and proliferate" (news/views). The authors describe neutrophil cells, which generally provide immunity, but, as it turned out, under certain conditions are able to stimulate metastasis. And although this process has not yet been properly studied, it is already possible to draw certain conclusions and warn against disease. At the end of the article there is a list of sources used. In the center of publication are given e-mail addresses of Emma Nolan and Ilaria Malanchi. The material is clearly structured and "embedded" in the scientific matrix (Nolan, 2020).

At the bottom and on the right, the key material is "framed" by other headings: "Flipping the switch on the thermoregulatory system", "Mountain-height can be controlled by tectonic force, rather than climate-driven erosion", "Quantum matter orbits Earth", "Tumour metabolites hinder DNA repair", "Light turned into exotic Laughlin matter", "Regenerative medicine could pave the way to treating baldness", "Primitive structures found using lidar mapping technology", "How DNA and RNA subunits might have formed to make the first genetic alphabet", "Thousands of human sequences provide deep insight into single genomes". All materials of this section are presented under the title "news/views.

Further below there is, perhaps, the most important section "Latest research articles", which includes only articles aimed at expert perception. It is obvious from article titles that this information is not for general public: "Cascade of electronic transitions in magic-angle twisted bilayer graphene", "Neurons that regulate mouse torpor", "Observation of Bose-Einstein condensates in an Earthorbiting research lab", "DNA of neutrophil extracellular traps promotes cancer metastasis via CCDC25", "Leveraging excited-state coherence for synthetic control of ultrafast dynamics". All these publications are classic scientific articles with usual structure: abstract, keywords, relevance, theoretical basis, novelty, methods, meanings, approbations, references. It is clear that materials are presented for a serious scientometric base. Access to the main text is limited and monetized. Abstract, code, references, information about the author, ethical declarations, extended data of figures and tables, rights, comments, etc. are given separately (on the side panel).

Under purely scientific articles, "Collections" section contains a lot of material about conferences, scientific titles and careers, social media, lab work, publishing houses, scientific databases and, most interestingly, scientific communication (Nature. "Collections", 2020). This publication is structured as a longread. In the foreword, editors note: "Most researchers try to present their results to other scientists. However, sometimes they need to convey ideas to wider audience. Here is a collection of articles that promote science among public and managers".

This column even contains intriguing materials. For example, in the article "Feeling stuck? Close your laptop, stop your field measurements and write a poem" Sam Illingworth explains how 
poetry helps to communicate and celebrate your science on the example of Vachel Lindsay's poetry, as well as references to "A Brief Reflection on Accuracy" by the Czech immunologist and poet Miroslav Holub, Sciku Project, which presents scientific discoveries and ideas in a haiku format, "the Universe in Verse" (an annual poetic celebration of science) and his own blog (Nature. Coronavirus conversations, 2020).

We are interested in the material of Pakinam Amer ("Coronavirus conversations: Science communication during a pandemic"), who explores the moral case for communicating science during the pandemic, as the choice between communicate- dissemble is close to problems of modern scientific and military journalism. Publication Thesis: Do scientists have a moral obligation to disseminate reliable information about the coronavirus? (Amer, 2020). Various experts comment on the situation. Ron Daniels, a critical-care consultant, believes that scientists, who work alongside cautious, risk-averse, called to avoid panic representatives of government and professional bodies, should carefully plug knowledge gaps. The scientist is supported by US science journalist Roxanne Khamsi, who highlighted that telling the truth - is organic human need, regardless of scientific status. Photojournalist and scientific writer Tara Haelle has opposed the outlined idea. She is deeply convinced that no one ever knows the final truth, so, generally speaking, journalists and scientists should focus on the good information and silence doubtful sensations.

In general, "Collections" are extremely important and valuable, as they are both a section, a forum for discussion and scientific database. Although there is a separate section "Scientometrics trends", which presents results of authors and publications ranking. On June 17, 2020, the leader who received 4616 likes was the material "Estimating the effects of non-pharmaceutical interventions on COVID-19 in Europe". The publication is a comprehensive work of a huge number of authors from the most prestigious universities on the continent. It contains extensive citations, sociological representations, results of research experiments, additional approbations, etc. In general, it seems that this is not an article, but a conceptual representation of the science of the future (Flaxman, 2020).

Next follows the section "Nature. Career". It announces various events: conferences, seminars, congresses, assemblies, as well as announcements about international vacancies, grants and other prospects for prestigious employment. And finally, there is information about the journal and its staff, press releases, ways to communicate with the editorial board, advertisements, partnerships, thematic columns, indexes, publication demands, manuals for potential authors, critics, editorial policy, open access, legal recommendations, additional services from researchers and editors, workshops, advertising, announcements, regional media subsidiaries in Asia and subsidiary projects, bibliographic data, etc.

In general, "Nature" makes a very positive impression: in all respects, this periodical is almost exemplary. It can successfully compete with both specialized scientific and universal media. "Nature" confirms our conceptual assumption about interrelationships between scientific and journalistic activities when working with facts and expertise.

Another foreign rating media periodical - NewScientist - is a daily bulletin closer to universal periodicals. This can be seen even from sections headings: "News", "Podcasts", "Video", "Technology", "Space", "Physics", "Health", "Mind", "Environment", "Crosswords". In this online media the highlight of today is not crucial and is presented only in eponymous column, the editorial of which is called - "This won't be the last pandemic. Where will the next one come from?" (New Scientist, 2020). This is not an article, but rather an essay filled not with expertises, but with selective facts that are taken from other world media, scientists' blogs and internal database. As a result, it makes impression far from thorough holistic research.

Worth following the experience of national online media ZN.UA ("Mirror of the Week. Ukraine"). First of all, because the editorial board originally forms sections (often new ones) on the latest issues. On March 6, 2020, there are four of them: "Zelensky's New Government", "US Presidential Elections", "Coronavirus from China", "War in Syria". At the beginning of the next week, instead of war in Syria, the topic of trial in MH17 case was introduced. On March 14, 2020, the status and list of sections are as follows: "Quarantine in Ukraine", "Trial in MH17 case", "US Presidential Elections", "Coronavirus in the World". On April 26, 2020 sections were somewhat 
"shuffled" and looked like this: "Fires in Ukraine", "Quarantine in Ukraine", "US Presidential Elections", "Coronavirus in the World". Headings for the first mentioned section are reflected in the materials: "Ukraine has opened a special flight for evacuation from Europe", "More than a hundred Ukrainian doctors confirmed Covid-19 in the last day", "Covid-19 pandemic: major events of the week".

And on May 6 (after heavy rains and drought ending) there were three sections left: "Quarantine in Ukraine", "US Presidential Elections", "Coronavirus in the World" (in two weeks this section was renamed "Pandemic Covid-19"). In addition, infection subject area has changed its vector: it is no longer about mortality statistics, protection and medicines issues, but how to overcome quarantine effectively, intensify economy and social protection. This can be seen from publications headings: "Contrary to the White House's statements, the Pentagon has outlined its own course on coronavirus", "Dnipropetrovsk region resumed passenger service: conditions for carriers named", "Coronavirus tests forgery: lab-head fired in Dnipro", "Split in EU over its rescue plan - Financial Times", "Coronavirus, Globalization and Nationalism", "Italy opens gyms and swimming pools", "US Graduates will receive diplomas at car parades", "Japan lifted state of emergency", "GZero: Can Putin counter Covid-19?", etc.

At the beginning of the summer, during the first wave of quarantine easing, the sections changed: traditional "Coronavirus in the World" disappeared, and popular sections "Quarantine in Ukraine", "US Presidential Elections" were added with "Trial in MH17 case", "Vradiyivka 2.0", "Protests through George Floyd's death". This trend reflected changes in visible emphasis, although incidence has been still progressing in some places. Eventually, in the first days of July, sections on quarantine and the pandemic disappeared at all, leaving "Protests through George Floyd's death" and two more: "ZNO2020", "Explosion in Kyiv skyscraper".

The most interesting section for us - "Coronavirus from China" (later renamed into "Coronavirus in the World" and "Pandemic Covid-19") - contains a huge number of publications. We offer a list of materials for only two days (March 6 and 7): "Ministry of Health has launched a chatbot on coronavirus", "WHO sends mission to Ukraine to counter coronavirus", "Quarantine center for coronavirus patients was destroyed in China", "Coronavirus in Europe: more than 200 people fell ill in France in a day", "One more citizen in Chernivtsi region is suspected of having Covid-19 infection", "Pope will read his message online due to coronavirus", "Covid-19 in economy: Asian dollars are sent to quarantine" "Facebook temporarily closed offices in England due to coronavirus infection", "Iceland declared state of emergency", "Grand Princess has 49 Ukrainians on board - Foreign Ministry", "Coronavirus: 12 cases of infection registered in Georgia", "Grand Princess: 21 people confirmed coronavirus", "The first infected with Covid-19 was found in Colombia", "Georgia evacuates its citizens from Italy", "197 people died of coronavirus in Italy", "Chernivtsi citizen fined for spreading rumors about coronavirus", "WHO dispelled hopes about coronavirus disappearance in summer", "EU predicts rapid increase in coronavirus infections in the coming weeks", "Coronavirus on board the liner: 12 new infected in Egypt", "More than 160 people are infected with coronavirus in Britain", "From March 7 restrictions at Donbass entry-exit checkpoint due to coronavirus spread in ORDLO - headquarters", "Coronavirus: the number of infected exceeded 100 thousand", "OPZZH deputy met infected colleague from France, yesterday he was in Rada", "Coronavirus in the world: first death recorded in the Netherlands", "Six cases of coronavirus infection in Ukraine have not been confirmed", "Coronavirus confirmed in one more European country", "Ministry of Health: 9 Ukrainians are tested for suspected coronavirus", "4 million hryvnias allocated in Chernivtsi to counter Covid-19", "Coronavirus infection in Wuhan may stop completely by the end of March", "Indonesia plans to place infected with coronavirus on a desert island", "Israel has declared quarantine in Bethlehem due to coronavirus", "Roman marathon was canceled due to coronavirus pandemic", "German airline company cancels more than 7,000 flights in March", "Woman hospitalized in Donetsk region for suspected coronavirus", "Egypt confirmed 33 new cases of coronavirus on board of a cruise ship" (Mirror of the Week. "Special column: pandemic Covid-19"). 
Media publications are very different in volume. For example, publication "Ministry of Health has launched a chatbot on coronavirus" highlights opportunity to learn about Covid-19 in Telegram-bot, it is also noted that DT.UA Telegram-channel "Coronavirus_info" is constantly working "with up-to-date and current information about COVID-19 virus situation in Ukraine". It is emphasized that this is the only Telegram channel verified by Ministry of Health (from which it can be concluded that "Mirror of the Week" has some benefits from cooperation with Ministry of Health).

Ministry of Health bot offers to get acquainted with popular questions: what is a coronavirus, what are its symptoms, how to avoid infection and treatment, how many cases of infection are confirmed in Ukraine, how virus is transmitted and tested, etc. (Mirror of the week. "Ministry of Health has launched a chatbot on coronavirus"). Publication contains hyperlinks to other materials on the site.

There is another publication ("WHO sends mission to Ukraine to counter coronavirus"), which also offers information from expert sources. In particular, we learn that World Health Organization is sending experts to Ukraine, Azerbaijan and Montenegro to monitor situation with COVID-19. The same publication provides access to previous materials on the site: "WHO dispelled hopes about coronavirus disappearance in summer", "WHO group will come to Ukraine to help organize anti-epidemic measures next week", "Coronavirus: the number of infected exceeded 100 thousand". In conclusion, it is reported that "Mirror of the Week" communicates only really important news and invite you to join already mentioned Telegram-channel DT.UA.

Under information publication we see keywords/tags: WHO, Azerbaijan, Montenegro, quarantine, coronavirus (probably to simplify the search and get to the top positions of search engines), as well as invitation to read the equivalent of weekly printed edition from February 28 to March 6 (issue of printed version, as you know, stopped in early 2020).

Printed issue is not accidental - there are old sections: "Power", "Money", "Man". So, this is something that is not on the site (Mirror of the Week. Archive, 2020-2021). "Quick view" link allows you to make sure: in virus section of printed newspaper there are only two publications (although next week "under this topic" were focused more publications, in particular - "Tuberculosis - fear epidemic, or How to make money from panic", "Survive yourself and protect business. Italian lessons", "How to improve your brain. Lesson 3 Books and knowledge that can counter viruses" etc.) in the section "Man. Health": material by Alla Kotlyar "System testing: coronavirus already in Ukraine" (Kotlyar, 2020) and Kristina Suvorina "Coronavirus in Italy: government is not going to close borders being afraid of economic losses" (Suvorina, 2020). But this is no longer news, but fullfledged analytics.

"System testing: coronavirus already in Ukraine" - is a classic article, written professionally, taking into account all aspects: theses, arguments, expertises, conclusions and advice. Thesis: majority of population in Ukraine is convinced of government inability to counter Chinese virus timely and effectively. Arguments are presented in the form of opinion polls "New Image Marketing Group", which answers the main questions: $51 \%$ of population believes that government will not counter the virus, $41 \%$ are afraid of getting sick, $45 \%$ believe that virus is - an artificial biological weapon. Then publication presents expertise of Andriy Skipalsky, Director of Public Health Directorate of Ministry of Health, and Viktor Lyashko, Chief State Sanitary Doctor. In such a way we find out: if a person is ill - he or she and people who have been in contact are isolated for quarantine (they are sent to infectious disease hospital if necessary), and the situation is monitored by telephone. If 10 people get sick - kindergartens, schools, universities are closed, and education and employment go online. "If more than 100 people fell ill - State Emergency Service and Ministry of Internal Affairs are being deployed. If necessary, military is also used”. (Kotlyar, 2020).

If printed issues of "Mirrors of the Week" periodical are completely self-sufficient and perfectly written, then web-site news should be considered as a part of longread content (in our opinion, this is how each section should look like in information technology era).

By the way, Kristina Suvorina's publication "Coronavirus in Italy: government is not going to close borders being afraid of economic losses" on March 14, 2020 was the first to disappear from the site (because the borders were closed) and then reappeared (Suvorina, 2020). Instead, the internal 
search engine offers other texts by this author (Archive (Suvorina Kristina)), (mainly - essays), who is probably in Italy - epicenter of European infection: "Citizents of three cities in Italian Lombardy were urged not to leave their homes because of coronavirus", "Ukraine must take into account Italy's experience to overcome coronavirus economic consequences", "Italy closes shops and restaurants. Business goes online due to coronavirus", "Coronavirus in Italy: fashion and show stars are trying to support their country”. In all these essays, Kristina Suvorina describes life in pandemic Italy as a witness. Of course, considering specifics of information, the author offers not an analytical approach, but a statement of facts.

Great interest is aroused by publication "Covid-19 pandemic: highlights of the week" (from May 26, 2020), as this review provides comprehensive information about the disease. Firstly, the reader's attention is caught by statistics. Despite the fact that foreword is not a place for numerals, in this case 440 thousand is a key and very eloquent number.

Subsequently, publication is divided into subtopics. The first block of information "COVID19 in the world" reports that "the largest virus epicenters are the United States (939, 235 cases), Spain (223,759 cases) and Italy (195,351 cases), "but the top ten already includes Russia, currently there are 74.5 thousand infected people in the country". This block also has a link to previous publication informing that to counter pandemic, UN General Assembly had adopted resolution on ensuring global access to medical equipment, drugs and vaccines to counter coronavirus. This resolution was initiated by Mexico, and Ukraine became one of its main co-authors" (Mirror of the Week. "Covid-19 pandemic: highlights of the week").

In the focus of subtopic "International Politics" there is conflict between administrations of the US and Russian presidents, who find China responsible for virus spreading and do not agree to cease hostilities in Ukraine, Syria and other countries (in response to French President Emanuel Macron, UN and G7 Security Councils). This discourse activates previous "Mirrors of the Week" 8 materials by keywords, which cover outlined perspectives of the problem in more detail.

The smallest by volume (but "filled" with two previous publications) subtopic "Economy" states that one hundred and three countries (out of one hundred and seven) are asking for aid from International Monetary Fund. In general, quarantine can cause famine in poor countries - oil exporters, which will still have to choose the "lesser of two evils" (Palivoda, 2020).

Problems of self-isolation, recreation, tourism and supply of reliable protection measures are raised in subtopic "Society". It is emphasized that not everyone agrees with quarantine regimes, specifically Russia and the United States even voice an objection, but most countries close tourist season until next year and transfer all important actions online. As a result, number of social networking users and other discussion platforms is growing. To learn more about some aspects of social issues - readers can use the link to 8 previous publications.

Especially valuable information (with 5 prepositional expertise) about virus origin, its resilience and immunity, is offered by subtopic "Science". Proper material arrangement does not provoke discussions - material contains comprehensive scientific summaries.

And - finally - subtopic "Ukraine" (with the help of activating nine previous materials) summarizes review and projects all aspects of the problem on internal state reality, and, as a result, readers can compare, weigh and draw necessary conclusions, etc.

Under review we observe descriptors: Ukraine, coronavirus, infection, health, pandemic, economy. These keywords will appear in the first lines of search engines for a long time in response to queries of the same name. Thus, the material is not only high quality and scientific, but also meets all the standards of modern mass communication.

As we can see, "Mirror of the Week" justifies its status as one of the most rated intellectual online media in Ukraine. By the way, in addition to scientific analysis, it offers a list of valuable recreational materials.

On March 14, 2020, another popular and status media Korrespondent.net in "Science" section offers (Korrespondent.net Science and Medicine, 2020) twelve materials, half of them is about coronavirus (presented in descending order): "Scientists announced major change in coronavirus 
genome", "WHO: coronavirus epidemic peak behind", "Scientists found how COVID-19 spread in China", "Effective coronavirus treatment found", "Scientists named possible viral pneumonia nidus in China", "Mission searching for life on Mars delayed due to coronavirus".

Unlike "Mirrors of the Week", "Correspondent" works inefficiently: these materials had been published during three months (although, of course, there were many other texts on health on the site). From genrology perspective, each individual publication resembles essay-reprint from other sources -own database absence is indicated. However, if we combine all the texts, we will have a unique and quite chronological overview of the problem.

Apart from texts, the section contains video material marked "video": "Coronavirus in Ukraine: latest news online", "What to do if you have symptoms of coronavirus infection?" "Germany started closing for quarantine", "Coronavirus pandemic: what should be considered when travelling?", "France closes all schools and universities due to coronavirus".

The most widely read publications are very different in Ukrainian and Russian versions. Russian publications are entirely devoted to the virus. "Scientists have proven coronavirus dependence on cold", "Zero patient found in China", "COVID-19 new phase spread", "Coronavirus in Ukraine. Latest news online", "Ministry of Health reported third COVID-19 patient condition". Ukrainian version: "Coronavirus in Ukraine. Latest news online", then sexual news, and - in conclusion - "Avakov: 12 COVID-19 infection cases in Horlivka". Alongside dissemination of information, it is 50\% dispelled in media and social networking. Alyona Romaniuk, a well-known fake expert and editor of "On the Other Side of the News" resource, promptly responded to misleading information about sick Ukrainians from Italy arrival (Nivroku, 2020). Several news websites republished this information, including students-journalists' website from Lesya Ukrainka East European National University.

News website "Letters", followed by "Rayan. Lutsk" and other media spread denial of doctor's advice, who is supposed to work in China and advise friends via phone how to behave in a situation of coronavirus infection (Rayan. Lutsk, 2020). It is worth saying, that this pseudo-message, like many others, looks quite realistic, and audio files are difficult to identify. However, journalists managed to convincingly contradict this information. In this case they used the help of Ilya Burlachenko, assistant professor of internal medicine №2 department at Bogomolets National Medical University, who treated the issue under different heads and, among other things he sincerely admitted that he only makes assumptions in many cases, and if more reliable information appears, WHO "will inform about it and make appropriate adjustments to its recommendations".

Since the beginning of the problem, lists of slightly forgotten fiction have been published everywhere (in particular, at our request "books about the pandemic" Google search engine offered 81 copies (MyBook - Electronic Library, 2020-2021)) and unnoticed in due time films about the pandemic. The first place of activation was received by the film "Contagion". BBC website has the following message: Steven Soderbergh's Hollywood film "Contagion", released in 2011, has never become a blockbuster. Despite the star cast (the film starred Matt Damon, Gwyneth Paltrow, Jude Law, Kate Winslet), the film took only $61^{\text {st }}$ place in the world according to box office revenue. However, nine years later, in 2020, "Contagion" was included in the list of the most downloaded films in the American iTunes Store, and the number of search queries containing this film's name on Google broke all records. If in December, when we first heard about the emergence of a new coronavirus in China, the film ranked only 270th place in popularity in Warner Bros studio catalog, now "Contagion" gives plays only to "Harry Potter" (BBC. NEWS, 2020).

In contrast to audiovisual boom, filming of essential issue in the field of investigative journalism remained relatively unnoticed - 41/289 episodes in general and the first episode of the eighth season of TV series "Agents of Justice" under the iconic name "Epidemic" (Agents of Justice, 2019). The film, by the way, appeared in early December 2019 (just before the pandemic outbreak, when it was not even mentioned).

According to film plot, Agency for Independent Investigative Journalism is approached by scientists who have been quarantined at a research institute after a leak of bacteriophage / antigen of 
the bubonic plague virus. Researchers understand that they have three days left to live, and ask to find out who the killer is.

Investigators - a passionate journalist and a private detective frustrated in the system of official investigations - understand that it is no longer possible to save scientists' lives, but they are doing everything to solve the crime and ensure the virus does not penetrate outside. Ironically, the leak still happens. And the whole Ukraine is going to quarantine ...

While watching the film, we learn a lot of valuable and interesting things about viruses' properties, bacteriophages, and ways to neutralize them. At the same time, we learn about the psychology and behavior strategies of criminal scientists. And although finally it turned out that panic was premature, the audience still remembers vigilance, knowledge and fear.

It is also interesting to follow the process of investigation and reconstruction of versions of the crime. The team, as we have already mentioned, includes a journalist, a private detective, as well as a psychologist, a ballistics expert, a criminologist, a physiognomist, a lawyer, a forensic expert, so data processing is fast and comprehensive. And there are many versions.

First, the assumption is made that someone unknown got into the lab and provoked catastrophe. After watching the video recorder, it is stated that only full-time employees were present at the institute when the crime happened. That is why new versions arise closely related to local scientists and their problems: from insults and settling accounts - to provocations and terrorism. However, new facts and events are narrowing the circle of suspects. Eventually, it turns out that everything happened "not according to criminal's scenario" who accidentally became a victim himself, but at the heart of the crime - envy, God complex and personal satisfaction.

While watching the film we learn a lot of new facts from the area of virology, psychology, criminology and, in addition to relaxation, we get a considerable amount of scientific knowledge and samples of schemes of classic journalistic investigations.

Alongside with knowledge production, as we have already noted, media also actively misinforms. Journalists use virus to raise their media rating. "And they are not completely ashamed in Europe - homeland of universal values and human rights - to establish panic and mock people, who are already frightened, because Europeans are not prepared to live and work in the context of difficult trials. Instead of working with state governments to explain, stop hysteria and objectively state the facts and localize pandemic, they create ratings and behave, to put it mildly, mean to their own audience" (Granite of Science, 2020). Sources of quoted information believe that all this is - a clear evidence of modern media inferiority. As if they had cooperated with political elite, virus pandemic would not have existed for a long time. But later authors contradict themselves because they state that Europe does not have laws regulating actions under the pandemic conditions. And they describe ideal situation: "After all, how could it have been? If several citizens of Northern Italy had got sick, gone to hospitals, consciously self-isolated ... However, "media brought horrors like fuel and the engine started working energetically spraying fakes: in Madrid, the number of infected has tripled - and no one knows what do".

Let's start with the fact that publication authors are scientists who, obviously, are not oriented in journalism area at all. Otherwise, they would understand: when there is chaos in Europe and no one knows what to do and how to treat it, media cannot regulate the situation. They only rebroadcast what happens. By the way, authors immediately confirm this themselves: "Europe does not even think of developing a law and solving the problem with coronavirus. Please note: Security Council of Europe is not meeting, no one is agreeing on how to act. All meetings are canceled ... Unfortunately, no one took responsibility. And we have what we have ...".

And even more unprofessional scientists' behaviour when they start advertising - "as salvation" - their textbook "Security of business circles in the XXI century". So, this is a clear negative example of unscientific approach used by experts to show their superior attitude to mass communication.

On June 9, eventually appeared the first representative investigation of IMM (Institute of Mass Media) how to correlate relationships between modern scientists and media (Institute of Mass 
Media, 2020), which warns the readers not to search for scientific material at news websites of Ukrainian online media. There is miserable number of them. Instead, there is a great possibility to watch astrological predictions everywhere. IMM experts stated that during monitoring period, average indicator of news about science in the Ukrainian online media was only $1,3 \%$. The largest amount of materials about research, experiments or popular science news was recorded at Suspilne website $-4 \%$ (from total news number at a monitoring period), at "Observer" $-3,8 \%$ and at "Mirror of the Week" $-2,8 \%$. At the same time, no material about science has been recorded at "Know" and "Interfax-Ukraine" websites. One of the most important monitoring conclusions is that Ukrainian experts, scientists and researchers comment on only one in five scientific materials $(20.3 \%)$. At the same time, comments from foreign scientists are dominating at the Ukrainian online media (79,7\%).

It is obvious that health topic came to the first place in the latest researches. (50\% of science media product). Journalists mainly reposted comments of foreign experts and specialized media. A large percentage of national product - hidden advertising (mostly - pharmaceutical companies and their intermediaries). The second popular topic appeared to be space $(17,7 \%)$. Universe has interested Earth population not in itself, but as a probable place of living, valuable resources source and place for tourism. It was reasonable to expect that the third position was occupied by digital technologies area (13.5\%): educational platforms, bots, entertainment media simulators.

No less predicted became the problem of anti-scientism and fake creation. Every third material about science turned out to be false (36.1\%). The favourite topic for imitation, without a doubt, are astrological predictions that appeared on websites of quite serious media: UNIAN, "Know", "Country", "Channel 24", "Observer" and, not surprisingly, received a huge number of views (in comparison with political, economic, culturological information). Serious and really scientific topics have also suffered, mainly from incorrect references, compilations, confusion with proper names of institutions, scientists' names and surnames and - most of all - social networking pseudo-expertise.

\section{CONCLUSIONS}

Therefore, scientific and journalistic activities are inseparable today. To state facts, certify expertise, define areas of thinking and interpretations, journalism has been forced to borrow the full range of scientific resources in the areas of collecting, analyzing, implementing and disseminating information. It is no coincidence that leading media editorial staff actively cooperate with scientists, using them as full-time and special correspondents and experts. As long as no activity can do without official websites, e-mail, social networking pages, database hyperlinks, cooperation will obviously deepen to situations of absolute "merging" of global system components. This can be seen from the example of rating online periodical "Nature", which in many respects surpasses activities of purely scientific corporate media. Trying to achieve this level, "Mirror of the Week" and a number of other Ukrainian and world media, which actively cover and try to solve the most pressing problems of mankind, such as the coronavirus pandemic. We hope that our investigation will accelerate media rationalization process and create multidimensional perspective on scientism researching in media. And these scientific works will become a source for objective verifying phenomena and processes of Postmodern science. 


\section{REFERENCES}

Amer, Pakinam. (2020). Feeling stuck? Close your laptop, stop your field measurements and write a poem. Sam Illingworth explains how poetry can help to communicate and celebrate your science. Nature, 27 september. https://www.nature.com/articles/d41586-019-02912-x

Bojko A. A., Zelinsjka N. V., Konovecj O. F. (2009). Naukova komunikacija u mas-media. Ljviv: Ukrajinsjka akademija drukarstva, 19-22.

Dzerkalo tyzhnja (2020, 26 travnja). Pandemija Covid-2019: gholovni podiji za tyzhdenj. https://zn.ua/ukr/WORLD/pandemiya-covid-19-golovni-podiyi-za-tizhden-346512_.html

Dzerkalo tyzhnja (2020, 7 bereznja). MOZ zapustylo chat-bot pro koronavirus". https://dt.ua/UKRAINE/moz-zapustilo-chat-bot-pro-koronavirus-340897_.html

Dzerkalo tyzhnja (2020, 7 bereznja). Spectema: pandemija Covid-19. https://dt.ua/theme/69

Dzerkalo tyzhnja (2020, 9 chervnja). Arkhiv. https://zn.ua/gazeta/archive/ Bila maghija ta antytila koronavirusu: shho i jak pyshutj pro nauku ukrajinsjki onlajny - doslidzhennja IMI. Instytut masovoji informaciji https://imi.org.ua/monitorings/bila-magiya-ta-antytila-koronavirusu-shho-iyak-pyshut-pro-nauku-ukrayinski-onlajny-doslidzhennya-

i33462?fbclid=IwAR3XwCFsfDGzVLnvD91wAvlSFn1IBNToBxo6-KnnhLL-yjZs6rLOqBh-zyc

Dzerkalo tyzhnja (2020, berezenj-chervenj). Arkhiv (Suvorina Khrystyna). Dzerkalo tyzhnja. https://zn.ua/ukr/search/query=\%D1\%85\%D1\%80\%D0\%B8\%D1\%81\%D1\%82\%D0\%B8\%D0\%B D\%D0\%B0\%20\%D1\%81\%D1\%83\%D0\%B2\%D0\%BE\%D1\%80\%D1\%96\%D0\%BD\%D0\%B0?da te_start $=\& d a t e \_e n d=\&$ news $=$ on $\&$ article $=$ on $\&$ photo_video $=$ on \&interview $=$ on

Flaxman, Seth and others. (2020). Estimating the effects of non-pharmaceutical interventions on COVID-19 in Europe. Nature, 08 june. https://www.nature.com/articles/s41586-020-2405-7

Ghranyt nauky (2020, 15 marta). https://un-sci.com/ru/2020/03/15/smi-kak-glavnyj-nositelkoronavirusa/

Korespondent.net (2020, berezenj-chervenj). Nauka ta medycyna. https://korrespondent.net/tech/

Kosjuk O. M. (2018). Masovokomunikacijni ckladnyky teorij klasychnogho racionalizmu: khronologhichnyj kryterij. Zbirnyk centru naukovykh publikacij «Veles» za materialamy IVmizhnarodnoji naukovo-praktychnoji konferenciji 2 chastyna: «Nauka i suchasnistj: vyklyky ghlobalizaciji». Kyjiv: Centr naukovykh publikacij, 71-76.

Kosjuk, Oksana (2016). Nova funkcionaljna modelj jak zaporuka reabilitaciji suchasnoji zhurnalistyky. Materialy III mizhnarodnogho internet-sympoziumu «Zhurnalist jak mishenj u suchasnomu sviti» http://esnuir.eenu.edu.ua/handle/123456789/10026

Kosjuk, Oksana (2019) Naukovo-populjarni bestselery jak javyshhe racionalizaciji informacijnogho prostoru. Arkhyvaryus. 29 (maj), 29-37. https://evnuir.vnu.edu.ua

Kotljar, Alla (2020) Test systemi: koronavirus vzhe v Ukrajini. Dzerkalo tyzhnja, 3 bereznja. https://dt.ua/HEALTH/test-sistemi-koronavirus-vzhe-v-ukrayini-340451_.html.

Kotova, A. (1997). Ghotfryd Vyljgheljm Lejbnyc (1646-1716). Kvant. Nauchno-populjarnыj fyzyko-matematycheskyj zhurnal, \#5, 3-5. http://kvant.mccme.ru/au/kotova_a.htm

Marinov, M., Todorova, L. (2020). Effects of the COVID - 19 Impact on the Tourism Sector in Bulgaria. Izvestia Journal of the Union of Scientists - Varna. Economic Sciences Series, 9(2), pp.6875. DOI: https://doi.org/10.36997/IJUSV-ESS/2020.9.2.68

MyBook - Эlektronnaja byblyoteka (2020, 2 yjunja). Эpydemyja. https://mybook.ru/tags/epidemiya/

Nature (2020, 17 june). Collections. https://www.nature.com/nature/collections

Nature (2020, 27 may). Coronavirus conversations: Science communication during a pandemic. How researchers can tackle an "infodemic" of hearsay, speculation and fake news. https://www.nature.com/articles/d41586-020-01589-x

New Scientist (2020, 17 june). This won't be the last pandemic. Where will the next one come from? https://www.newscientist.com/article/2246259-this-wont-be-the-last-pandemic-where-willthe-next-one-come-from/ 
Nivroku (2020, 13 bereznja) Vypusknycja nashoji zhurnalistyky rozvinchuje fejky. https://ff.in.ua/2020/03/13/vypusknytsya-nashoyi-zhurnalistyky-rozvinchuye-fejky/ Эpydemyja. MyBook - Эlektronnaja byblyoteka. https://mybook.ru/tags/epidemiya/

Nolan, Emma and Malanchi, Ilaria (2020). Neutrophil 'safety net causes cancer cells to metastasize and proliferate. Nature, 11 june. https://www.nature.com/articles/d41586-020-01672-3

Palyvoda Andrij (2020). Nadija sv koronakryza. Dzerkalo tyzhnja. https://zn.ua/ukr/macrolevel/nadiya-vs-koronakriza-342685_html (2020, 26 bereznja)

Rajon. Lucjk (2020, 16 bereznja). Porady vid likarja, jakyj pracjuje v Kytaji, - fejk. https://lutsk.rayon.in.ua/news/228830-poradi-vid-likaria-iakii-pratsiue-v-kitayi-feik

Suvorina Khrystyna, 2020, Koronavirus v Italiji: vlada ne planuje zakryvaty kordony, pobojujuchysj ekonomichnykh zbytkiv. Dzerkalo tyzhnja. https://zn.ua/ukr/HEALTH/koronavirusv-italiyi-vlada-ne-planuye-zakrivati-kordoni-poboyuyuchis-ekonomichnih-zbitkiv-340081_html (2020, 28 ljutogho)

VVS. NEWS (2020, 14 bereznja). https://www.bbc.com/ukrainian/news-51887556

YouTube (2019, 28 zhovtnja). Aghenty spravedlyvosti. Sezon 8. 2019. Epidemija. https://www.youtube.com/watch?v=FG0Vqp_ctcw \&t=3s 


\title{
STUDENTS 'ADAPTATION TO LEARNING AS A PSYCHOLOGICAL PROBLEM
}

\author{
Natalia Gerasimova, Inna Gerasymova, Svitlana Dmytryuk \\ ${ }^{1}$ Candidate of Psychological Sciences, Associate Professor, Scientific-and-Research Institute of Pedagogical Education, \\ Social Work and Arts, Bohdan Khmelnytsky National University at Cherkasy, Ukraine \\ ${ }^{2}$ Candidate of Pedagogical Sciences, Associate Professor, Transactional Analyst, Scientific-and-Research Institute of \\ Pedagogical Education, Social Work and Arts, Bohdan Khmelnytsky National University at Cherkasy, Ukraine \\ ${ }^{3}$ Senior Lecturer, Department of Arts and Light Industry Technologies, \\ Kyiv National University of Technologies and Design, Ukraine
}

ORCID ID ${ }^{\circledR}:{ }^{1} 0000-0001-5455-4891,{ }^{2} 0000-0003-3981-1428,{ }^{3} 0000-0001-6428-4856$

\begin{abstract}
The analysis of the current state of the issue in modern socio-psychological literature provides a comprehensive insight into adaptation. The concept of adaptation is used in many sciences as a tool for understanding the process of interaction of the organism and its environment. Studies show that a person who gets into a new environment and starts a new activity undergoes physiological changes of the body oriented to the new work process: the rhythm of work, rest, sleep, mental work load, muscle activity, metabolism, blood pressure and new emotional sufferings. Human adaptation to the environment also implies involvement in specific social relations, which play a major role in his adaptation. Adaptation and ability to it is a prerequisite for future activity, a necessary condition for its success without feeling discomfort, tension and internal conflict of an individual with the professional and social environment. The concept of adaptation in the modern psychological literature is inextricably linked with the problem of optimal interaction between an individual and the environment as a concept that allows you to assimilate and bring to the system factors obtained at different stages of research - from sociological to individual psychological one. Effective social adaptation is one of the prerequisites for successful professional activity.
\end{abstract}

\section{INTRODUCTION}

The initial stage of professional training is interpreted by researchers as a stage that determines the entire course of further human life. At this stage the process of adaptation to educational activity in a higher educational institution takes place. It happens because at this period a person finds himself in a challenging situation of learning new forms of activity, communication, leisure and he correlates his expectations with reality. Research in the field of general psychology aimed at studying the individual characteristics of students during the adaptation process to learning in a higher educational institution is characterized by a general tendency to identify only the general characteristics of various types of personality adaptation at this stage of development. At the same time, the peculiarities of the process of students' professional and personal growth at various stages of their adaptation to the learning conditions in a higher educational institution, depending on the influence of factors that affect the adaptation process, require in-depth study. Adaptation of the student's personality takes place in the team (group, faculty) and through the team. And in this case the initial stage of adaptation in a new social environment is of special interest. Adaptation in the team is a prerequisite for productive social activity, self-determination of a personality, the development of the student's individuality.

The primary task of creating the theory of adaptation in a higher educational institution is to define this concept at the general level. I. Liakhova and A. Uchytel, within the framework of the general concept of adaptation in a higher education institution, distinguish (Liakhova, 2001):

1) professional adaptation is a process of human entry into the profession, which is expressed in the acquisition of knowledge, skills and abilities necessary for future professional activity;

2) didactic adaptation is students' adjustment to a new form of educational work for them;

3) students' adaptation to new learning and teaching conditions in a higher educational institution is the process conditioned by getting of an individual into a new educational system under the guidance 
of lecturers who form the structure of his activities due to the new organization of education and socialization, which is a methodological prerequisite for student learning.

In the process of adaptation to training in a higher educational institution students go through the following stages:

1) pre-adaptation stage, at which the student receives information about the new situation as a whole, the criteria for evaluating various actions, the norms of behavior in the team;

2) adaptation stage, at which the student refocuses himself, recognizing the main elements of a new value system, but still continues to maintain his numerous attitudes;

3) post-adaptation stage, which is carried out when the student is fully adapted to the environment, is identified with a new group, when the personal goals of a student are identified with the goals of the educational institution;

4) primary adaptation to the profession in the learning environment of a higher educational institution.

\section{METHODS}

Adaptive behavior is characterized by successful decision-making, initiative and a clear definition of one's own future. An adaptable person does not run away from difficult situations, but uses these situations to achieve his aspirations and goals.

The concept of adaptation in the modern psychological literature is inextricably linked with the problem of optimal interaction between the individual and the environment as a concept that allows you to assimilate and bring to the system factors obtained at different stages of research - from sociological to individual psychological one.

N. I. Bulka emphasizes that high level of adaptation is accompanied by:

"self-strength", emotional maturity, real assessment of the situation, social courage, which can be compared with such a function of social intelligence as ensuring adequacy, adaptability in changing conditions.

Low level of anxiety and depression, lack of frustrating tendencies associated with the mobilization function, which helps to overcome sudden crises and prolonged stress.

Activity which is related to the energy features of social intelligence (Bulka, 2004).

As the basic principle of adaptation F. H. Khairullin considers the adjustment of an individual to the conditions and the content of a particular activity through gradual, but systematic performance of actions in new conditions. Depending on the nature of an individual's attitude to a new environment, the author distinguishes two types of adaptation: creative and formal (Khairullin, 1972).

Creative adaptation is understood as a certain adaptation to the learning process: deep and solid knowledge, the formation of creative thinking and skills of a future specialist, general activity in cognitive activity.

Formal adaptation takes place in the case of adjustment not to successful acquisition of knowledge, but to "pushing the matter through", i.e. to obtain knowledge and a diploma. In this case, students focus only on the exam session.

The adaptedness of an individual in terms of higher education is manifested in the following:

1) assessment and reaction of an individual to the situation;

2) the correlation of one's behavior with the current situation and the individual's acceptance of social role depending on the structure of needs and motives, that is, the type of adaptation process;

3) correspondence between goals and results (adaptability)

Some researchers emphasize the need to prevent maladaptive state of students during their studies in a higher educational institution by identifying a certain degree of adaptability and maladaptation to a new social environment (Miloslavova, 1970; Noskov, 2003; Osnitsky, 2004). Comprehensively studying the process of adaptation of students to learning in a higher educational institution, it is important to ascertain the effect of certain factors on this process. N. Y. Gerasimova, when determining the mechanisms, factors and criteria of adaptation, gives the following considerations: the movement of a person who adapts himself in the adaptation process is a stage of this process with 
its inherent properties, that is, factors that often act as mechanisms. As soon as the movement at this stage ceases, the property of the stage turns into criteria and its features (Gerasimova, 2005).

I. O. Heorgiieva considers that the factors are the conditions and prerequisites that determine the process and the result, the success of human inclusion in a new social environment (Heorgiieva, 1985). M. O. Svyrydov defines the factors as a set of conditions that determine the process (pace, stability) and the result of adaptation (Svyrydov, 1992).

I. V. Gerasymova emphasizes that "One can agree that factors are a set of conditions and prerequisites that determine the adaptation process while criteria are a feature of the adaptation process and its result (Gerasymova, 2002).

The author draws attention to the complexity of the structure of factors, which can be described on many grounds: socio-economic, socio-demographic, socio-psychological, psychophysiological aspects in dichotomies (general - special, internal - external, basic - non-basic). Considering factors as motives for human behavior, she accentuates a motivational core - a stable combination of factors, which mainly determines the process and the result of adaptation, that is, there is also some mixing of factors and criteria.

According to O. I. Zotova and I. K. Kryazheva, the factors influencing the adaptation process are the conditions of human life and activity. In particular, the assessment and the perception of these conditions, in the first place, are mediated by the attitude to the content of work and the purpose of activity. Meanwhile, depending on the characterological features of a personality and non-dominant aspects of the motivational structure, the conditions of activity can significantly affect the nature and the result of adaptation. On the other hand, the very motivational structure of a personality, to a large extent, is the result of personality traits, and depends on the abilities, internal tendencies, emotional orientation and personal qualities. That is why some authors suggest that the correspondence of some personality traits to special aspects of an activity, in particular, professional, can be a condition and an indicator of a human adaptability (Zotova, 1979).

To the factors that influence the personality's adaptation, some authors refer social and psychological characteristics of the team - the nature of the relationship between ordinary members (horizontally), the nature of the relationship between managers and subordinates (vertically), team leadership style and its socio-psychological climate.

I. O. Heorgiieva divides factors into personal and external. To personal she refers: 1) sociodemographic characteristics of the participants of adaptation (sex, age, marital status, children, living conditions); 2) value orientations as a meaningful component of the system of subjective relations of a personality; 3 ) a number of psychological personality traits.

External factors are represented by a set of parameters related to the type of group activity. These may be specific characteristics of the activity: the content of the activity (work and knowledge); the organization of the activity (the degree of regulation of activity, the possibility of individual variability of ways and methods of the activity, the forms of control over process and result); the position in the system of social production; the objectivity of the results of the activity; the ratio of formal and informal structures of relations in the social organization of a team; incentive system; age homogeneity of a team; the degree of participation of individuals in the formation of group norms (Heorgiieva, 1985).

Factors are also divided into subjective and objective. Objective factors are less dependent on the student. This is the level of organization of education, hygienic and sanitary conditions of education, the size of a team, the location of a higher educational institution, the industry specialization, etc.

Subjective (personal) factors include:

1) Sociodemographic characteristics of a student (gender, age, previous education, social status, etc.);

2) Social and psychological - the level of demands, willingness to learn, efficiency, speed of orientation in a learning situation, self-control and the ability to act rationally, social skills, adequate self-perception; 
3) Sociological - the degree of moral and material interest in the effectiveness and quality of education, the presence of guidelines for improving the level of education, etc (Noskov, 2003).

It should be noted that all the factors are interrelated. S. S. Kuzmin and O. O. Prokhvatilov believe that the beginning of adaptation does not coincide with the appearance of a person in a new group, but refers to the previous period. In this case an important role is played by subjective factors, namely, making a decision regarding the choice of a specialty or a desired social environment, the formation of an attitude towards a future profession and people who can become colleagues (Kuzmin, 1981).

In the process of professional self-determination, young people go through four stages.

The first stage of adaptation (professional self-determination of young people) falls on the first year of study in a higher educational institution. Its goal is to form students' interest to themselves and their peers as interesting objects for studying and observation, adaptation to new forms and methods of educational activities.

This adaptation has three forms:

1) formal adaptation, which means the cognitive and informative adaptation of students to a new environment, to the structure of a higher school, to learning content, to its requirements and responsibilities;

2) social adaptation, i.e. the process of internal integration of the same groups with student environment as a whole;

3) didactic adaptation, which correlates with the preparation of students for new forms and methods of educational work. Of particular importance at this stage is the work of group tutors, who organize individual talks, consultations on self-study and self-education. As a result of such work, interpersonal contacts are improved, trust is established in the group a lot of students start engaging in self-improvement, the number of nervous breakdowns during the first-year exam session is reduced.

The second stage (students' adaptation to the requirements of the profession) begins at the second year of study in a higher educational institution. It is characterized by the fact that a student acquires necessary professional knowledge and practical skills in the learning process to carry out specific activities in the chosen specialty. This approach creates a certain target setting, which has a positive effect on the process of future professionals training.

The third stage (dynamics of students' professional training in a higher educational institution) covers senior courses. Its main purpose is to complete the process of forming future specialist's personality.

The fourth stage (young specialist's professional adaptation and his professional growth). This stage acquires special significance during graduate studies. The formation of the personality of a future specialist-researcher and his training are facilitated by both general educational basic disciplines and special ones (research methodology, teaching methods of academic disciplines in colleges, gymnasiums and lyceums, speech culture, educational technology, etc.). In the course of studies Master's degree students' capabilities to predict, plan and conduct research related to the theory of teaching or education are revealed and studied (Kirei, 1986).

In the process of social adaptation, the correspondence between behavior and activity is achieved, which is approved by society and personality structure, his interests, values and orientation. Personality orientation and activity level are used as the adaptation criterion.

Most typically, three main directions of activity orientation, corresponding to three types of adaptation to the changed situation, are distinguished:

1) a way out of the situation, psychological protection of one's own "I";

2) impact on the environment in order to adapt its parameters to oneself: from direct impact to the search for workarounds;

3) self-transformation, one's internal structure: from habituation, balance with the environment to assimilation (Dolina, 1978).

Human adaptation to the environment also involves inclusion in specific social relations, which play a major role in his adaptation. In a number of scientific works [20] adaptive processes are 
associated with the processes of social personality, it is distinguished a qualitatively higher degree of adaptation - social, which is a specific social phenomenon, based on the interaction between social subject and social object - the conditions of its social existence. The subject of social adaptation is a person, a personality as an individual being of social relations. Social environment is seen as an object of a personality's adaptation.

In many researches social adaptation is understood as adjustment of an individual to new conditions of social environment and its result. "The ability to adapt to different circumstances characterizes the process of formation and development of a personality, its professional growth. In case of maladaptation, not only personal and professional development can be disturbed, but also the psychological capabilities of the body can be reduced, and even health disorders are possible "(Ershova, 2000).

The following classification of social adaptation is used in the works of I. A. Miloslavova: 1) according to the nature of interaction between the subject of adaptation and the adaptive environment (adjustment);

2) according to the type of adaptive environment to which the individual is adapting or which he adapts to himself (friends' environment, learning process);

3) according to the structural components of adaptive environment (object-activity oriented and personal). In particular, to the microclimate, to social values, interpersonal relations, to the style of management and leadership and the like;

4) according to psychological content (adaptation to situations, including imaginary ones, attitude to adaptation, becoming estranged from usual living conditions, inability to adapt to the new conditions of social environment, etc.) (Miloslavova, 1970).

G. E. Mednikova emphasizes that the term "social adaptation" in terms of the basis, is the first step for self-development, has not yet been widely used in the social sciences, but the objective processes of integration, diversification, information society dynamics are attracting more and more attention to the development of the social adaptation theory. New concepts including timeserving: "passive adaptation", "pseudoadaptation", "accommodation" are appearing in it (Mednikova, 2003).

Passive adaptation is directed to use the socio-economic and psychological resources of a personality by means that were formed before. It is often carried out by lowering the level of aspirations and simplifying consumption standards. In the case of superficial adaptation, which is a consequence of passivity, there are no radical changes in the structure of the one who is adapted, in the means and the nature of interaction with the environment.

It is also distinguished pseudoadaptation, in which external adaptation to the environment is combined with the negative attitude towards its norms and requirements. A complex set of adaptation measures is formed. It masks explicit attitudes and goals and allows the subject to survive in difficult conditions.

\section{RESULTS}

To characterize adaptation in the conditions of a protracted conflict between the environment and the subject, when the subject cannot change the environment "for himself" and at the same time cannot accept the environment due to his value attitudes, the concept of "accommodation" is used. Accommodation is the temporary resolution of a conflict through mutual toleration, compromise or coercion. Accommodation (or the process of adjusting to conflict situations) is carried out by keeping the distance between social groups, people and society. Considering a higher educational institution as a social object, socio-pedagogical system, and a young person's entry into a university as its transition from one system to another, it is logical to consider adaptation to the conditions of a higher educational institution as a kind of social adaptation, which manifests itself in the specifics of the interaction of an object and a subject (Sorochinskaya, 2005).

It is from these steps that the attitude towards future professional activity, towards professional environment and its values begins to form. The active search for personal self-identification, one's place in role distributions, and conventional coordination in the socio-psychological structures of social communities continues. 
V. P. Kazymirenko defines socio-psychological adaptation as a process of establishing the optimal correspondence of a personality and professional and educational environment in the process of carrying out the chosen independent activity, which allows a person to meet current needs, form personal and socially significant intentions (Kazymirenko, 2004).

When determining the socio-psychological adaptation of students to a higher educational institution, researchers identify a number of characteristic features, to denote which such terms as "activity", "creativity", "adaptation" and "involvement" are introduced. Based on the literal meaning of the word "adaptation" as an adjustment, its meaning is reduced to the acquisition of skills and abilities that make a person suitable for certain conditions. According to P. A. Prosetsky, sociopsychological adaptation of students is considered as "active creative adaptation of newly enrolled students to the conditions of a higher educational institution, in the course of which they develop optimal relationships, devotion for the chosen profession, rational collective regime of work and life" (Prosetsky, 1970). He emphasizes that the socio-psychological adaptation of students in the environment of a higher educational institution includes the following aspects:

1) professional adaptation, which determines the adjustment to the content, conditions and independent organization of educational activities, the formation of skills and directions in educational and scientific work;

2) socio-psychological adaptation, as one that determines the active (or passive) adjustment of a personality to the environment, building relationships in student groups, the formation of a style of personal behavior;

3) socio-professional adaptation as the acceptance of social requirements for future professional activity.

S. I. Silvestrov emphasizes the need to implement students' adaptation according to the sociopsychological direction - providing assistance in adapting to a new team. "The adaptation process is largely influenced by the individual psychological characteristics of students, their intellectual abilities, value orientations, professional aptitudes and inclinations ..." (Silvestrov, 1997). In addition, students represent a socio-psychologically heterogeneous group, the differences within which are determined both by socio-demographic factors (origin, social status, gender and age), psychological characteristics (communication, cultural level, independence), and motivation of activity. This leads to different levels and "speeds" of adaptation, which, to some extent, can be determined by the following main types of manifestation: the ability to organize yourself, your life, leisure, learning; ability to plan your class and personal time; formation of skills and abilities of educational activity; the prevalence of a good mood and self-confidence; friendliness and sociability; positive attitude to their future profession; state of health.

N. G. Kalnaia emphasizes the importance of socio-psychological teaching methods, which make it possible to increase several times meaningful communication between lecturers and students, promote students' creative non-standard thinking formation, cognitive interests development, stimulate and actualize deep personality associations, make participants form personal and business qualities (Kalnaia, 2003). Such active methods as sensitive training, discussion and role playing provide systemic and integrated approach in solving many problems that arise while students take the role, specifically socialization role, in the processes of socialization and adaptation to learning conditions in a higher educational institution. The objectives of such activities are to create and develop a social field, the system of communication for students of different levels, but also to explain the essence of the student's role, his opportunities and responsibilities.

The important aspect of social adaptation is role acceptance. The nature of a person's life scenario, lifestyle and behavioral strategies in various life situations depend on it.

The process of role development and role behavior occurs in the context of a very important process for the personality's life, which is called socialization (Osnitsky, 2004). According to most definitions, the person's socialization is the assimilation of social experience, social norms and values by a person. One of the main components of human socialization is the assimilation of social roles. First, in social roles, the norms and rules of social behavior have been established as role models, i.e. the requirements for fulfillment of social roles. Second, role behavior is the most important type of 
social behavior, and social roles are a means of incorporating a personality in a group and a society, a form of social adaptation and personal self-expression at the same time. Characteristic features of role socialization lie not only in the assimilation of social expectations to social roles, but also in the role development of a personality, i.e. the formation of psychological roles, both social and personal, interpersonal, characteristic, life, and the like.

The transition to a new social role, the role of a student, the change of the usual school environment to an unfamiliar higher education environment takes time to adapt, even when within the walls of a higher educational institution a student meets a friendly attitude from the teaching staff. This is due to the fact that the student's life is built according to new rules and regulations, the sense of responsibility for what the future will be is growing up.

Such attitude for some students can lead to certain difficulties and the formation of a distorted role of a "student", namely, the replacement of a real sense of adulthood with such manifestations of behavior as the freedom of attending classes, external forms of self-realization (smoking, communication style). This happens due to certain difficulties of socialization, which are manifested in the unwillingness to study and to attend an educational institution.

The state of internal stress, like any other emotional event or phenomenon in a person's life, negatively affects both the intellectual and personal development of an individual. If mental stress continues for a sufficiently long period, then along with the growth of negative experience, a situation may arise in which a student will not want or will not be able to continue his studies at a higher educational institution. This is caused by the fact that psychological stress can adversely influence the course of mental processes, and the consequence of this can be learning disabilities, complications of relations in the academic group and, finally, unwillingness to study.

Role socialization acquires special significance during the first year of study at a higher educational institution. "Students are in new conditions for themselves: a new environment, a new knowledge system, the lack of daily knowledge assessment, and under these changing conditions they need not only to learn professional knowledge, to increase their theoretical and practical skills, but also to build their relationships with others, to form a new self-image" (Dolina, 1978). The educational process in a higher educational institution is a transitional purposeful system in which the personality's socialization process consists of two stages: the stage of adaptation to the conditions of being in this system and the stage of adaptation to the conditions in which a person will find himself in the next system. The optimal mode is when each of the previous general systems of the hierarchy, social system of a personality's socialization solves the problem of comprehensive human preparation for the transition to the next system.

According to the researches of I. Liakhova and O. Uchytel, the first stage of socialization of the student's personality, i.e. the stage of adaptation to the conditions of a higher educational institution takes place at two levels - purposefully organized (controlling) and spontaneous. The controlled level is a purposeful influence of higher educational institution staff and its constituent structures on development of a student's personality traits necessary for successful study at this higher educational institution as the initial task of the educational process in it. Solving the problems of this process presupposes the conscious acquirement of the corresponding norms and values in the process of active learning, social activities of a first-year student (Liakhova, 2001).

Studying the basics of the freshmen's adaptation problems in a pedagogical higher educational institution, O. M. Halus differentiates five aspects (subsystems):

1) the energy subsystem reflects the resource capabilities of the organism, their ability to ensure the functioning of the main systems of the organism in conditions of increased energy consumption;

2) the environment subsystem reflects the student's attitude to those external-objective conditions that surround him;

3) the activity subsystem reflects the student's ability to perform educational activities that make up the main content of his activities in a higher educational institution: mastering new actions, managing acquired skills, which are not appropriate in new conditions; 
4) the social subsystem reflects the student's entry into a new social environment.

The social aspect of adaptation is characterized by the degree of student perception of norms and rules of life in the new social environment and the way student is perceived by this environment;

5) the personal subsystem reflects the overall result of adaptation, when a student feels psychologically comfortable in his life conditions, considers it constructively significant, which in general opens up further prospects for the development (Halus, 2004).

Besides, in the learning process, a person is placed in the situation where he is assessed, which gives rise to certain negative states of this person. Therefore, there is an increase of stressful situations, their effect on students, and hence on the learning process. At school, a student, as a rule, comprehends permanent, generally accepted forms of knowledge, his development is formed in a stable coordinate system (plus - minus), or, in other words, unidirectionally. This unidirectionality produces a stable psychological stereotype of student's behavior, which is the classic manifestation of conformity. As N. G. Kalman emphasizes, this is often the way to alleviate mental well-being at school, in a higher educational institution, on the contrary, such a basis (conformity) is often the beginning of students' negative mental states (Kalman, 2003).

Coming to a higher education institution with such a worldview, young students do not have time to get used to the dynamic educational process, full of a large number of special courses and teachers. Most courses in higher educational institutions are determined during the semester. During this period, a student does not have time to realize the psychotype of the teacher's behavior, it is difficult for him to assess the level of his professional competence.

Studies at a higher educational institution coincide with the second period of adolescence or the first period of maturity, which is characterized by the complexity of personal traits formation. A characteristic feature of moral development at this age is the increase of conscious motives for behavior, which young people lacked before. Interest to moral issues is increasing.

Along with this, psychologists and physiologists note that the student's ability to consciously regulate their behavior is not developed at the proper level. There is often an unmotivated risk of not being able to anticipate the consequences of one's actions, which may not always be based on decent motives.

A significant role in the activities and development of students is played by worldview, that is, the system of ideas, beliefs and views. It is manifested in the understanding and evaluating reality, in person's social behavior, his actions, activities, it has an impact on feelings, will and motives.

Distinctive features in the students' behavior and activities are caused by differences in their temperament. Temperament not only affects the manifestation of feelings and the speed of switching attention, but also other mental processes: the students' behavior at classes, exams, their reaction in difficult situations, reaction to questions, tasks and assessment. As a rule, this is where the objective basis is hidden, from which such negative mental states as insecurity, irritation, aggression and fear subsequently arise.

According to surveys and psychodiagnostic examinations conducted by S. O. Haponova, typical adaptation problems are:

1) false, inadequate expectations and illusions about learning;

2) "external" motivation for learning (for example, learning "for parents");

3) uncertainty of life plans and goals;

4) unfamiliarity with behavioral norms and standards adopted in the students' environment;

5) uncertainty of their own learning strategy (Haponova, 1994).

During the adaptation period the formation of socio-psychological unity of the student collective takes place, which acts as a powerful means of introducing the personality to new social functions, to the system of new relationships, needs and interests. The academic group is the closest environment in which a freshman adapts himself to the higher educational institution standards of life and activity. In it, with the help of personal communication, the student interacts with this social environment, which has a great influence on his behavior through various types of group control (public opinion, system of value orientations, etc.). Responsible attitude to learning process and social practice, labor and academic subject is formed in the team, as well as the associated problems are 
solved there. Conditions for the development of positive personality traits and overcoming negative ones are created in it. Therefore, the need to accelerate relationship-building in the freshmen's study groups plays an important role. Socially significant activities of the group members and the relationship between them can stimulate this process.

Studying the psychological essence of interpersonal relations, A. Petrovskyi points out that they form various layers of group activity in the team. The first layer forms a set of interpersonal relations of direct dependence (emotional attractiveness, group compatibility, etc.). The second layer forms a set of defined socially valuable and personally significant activities determined by the content. The third one is a set of collective relationships, the basis of which is socially and personally significant activity (Petrovskyi, 1982).

\section{CONCLUSIONS}

In modern scientific research, adaptation is considered as an important theoretical and practical issue, the solution of which depends on the preparation of young generation for working life in a society.

Therefore, the tasks set by scientists are aimed at studying the psychological foundations of adaptation, identifying factors that affect the intensity of this process, establishing indicators of the level and degree of adaptation, identifying ways to purposefully and consciously manage them.

Having analyzed the process of students' psychological adaptation to studies in a higher educational institution, we identified the conceptual model for studying adaptation to a higher educational institution, which contains the components of adaptation - adaptation to learning, professional activity; adaptation criteria (objective and subjective), as well as adaptation factors social and personal. Moreover, the relations between the presented areas of study emphasize the importance of the personal factor, its representation in the components, conditions and the stages of adaptation.

The success of adaptation depends on many constituents: adaptability, plasticity and flexibility of nervous system; intellectual and creative abilities; motivational structure of the student's personality. The relationship between the level of student's socio-psychological adaptation and the student's educational activities is dialectical. The important factor influencing success is the motivation of educational activities and the desire to succeed in it.

\section{REFERENCES}

Bulka, N. I. (2004). Resources of social intelligence: adaptability, communicativeness, creativity. Practical psychology and social work, 6, 43-53.

Haponova, S. O. (1994). Features of adaptation of university students in the learning process. Psychological journa, 3, 131-136.

4. Heorgiieva, I. O. (1985). Socio-psychological factors of adaptation of the personality in the team [Monograph], 160.

Gerasymova, I. V. (2002). Theoretical prerequisites of students' adaptive abilities to the conditions of study at the university. Visnyk of Cherkasy University, 55, 44-49.

Gerasimova, N. Y. (2018). Creating conditions for the realization of adaptive capabilities of students in higher education in the educational process. Visnyk of Cherkasy University, 34, 40-46.

Dolina, O. P. (1978). Socio-psychological factors of social adaptation of students of 1-2 courses. Higher and secondary pedagogical education, 10, 83-87.

Ershova, N. G. (2000). Methodological aspect of psychological and pedagogical support of the educational process during the adaptation of students to training in higher education. Theory and practice of physical culture, 5, 14-17.

Zotova, O. I., Kryazheva, I. K. (1979). Some aspects of social and psychological adaptation of the individual. Psychological mechanisms of regulation of social behavior, 155-159. 
Kazymirenko, V. P. (2004). The program for the development of psycho-social officials in the adaptation of young people at the Higher Education Institution and the future profession. Practical psychology and social work, 6, 76-78.

Kalman, N. G. (2003). The relationship of physiological and psychological indicators in the process of adaptation in students. Education in the context of social adaptation of students, 2, 52-54.

Kalnaia, N. G. (2003). On the experience of using active socio-psychological methods of teaching and upbringing in the process of adaptation of freshmen. Education in the context of social adaptation of students, 2, 141-144.

Kirei, N. I. (1986). Psychological and pedagogical foundations of the adaptation period of freshmen. Modern higher school, 3, 109-123.

Kuzmin, S. S., Prikhvatilov, O.O. (1981). On a systematic approach to the study of adaptation processes. Psychological problems of increasing the efficiency of production teams, 5-47.

Kuzminsky, A. V. (2003). Psychological, pedagogical and organizational conditions of adaptation of Ukrainian students in higher educational institutions abroad. Ridna shkola,2, 23-26.

Lyakhova, I., Uchytel, A. (2001). The use of systems analysis in the process of adaptation of first-year students. Native school, 1, 61-63.

Miloslavova, I. A. (1970). The concept of social adaptation. Questions of philosophy and social psychology, 45-59.

Mednikova, G. E. (2003). Adaptation and self-realization of the individual and the role of contemporary art in this process. Higher School, 32(3), 71-78.

Noskov, V. I. (2003). Development of creative activity in the context of social adaptation of students. Education in the context of social adaptation of students, 2, 22-24.

Osnitsky, A. K. (2004). Determination of the characteristics of social adaptation. Psychology and school, 1, 43-56.

Petrovskiy, A. V. (1982). Personality. Activity. Team, 121. Prosetsky, P. A. (1970). Sociopsychological problems of the educational team, 106.

Svyrydov, M. O. (1992). Development of personality and tasks of psychology in the Higher Educational Institution, 63-66.

Silvestrov, S. I. (1997). Some problems of adaptation of first-year students in higher education. Problems of education, 10, 135-140.

Sorochinskaya, V. E. (2015). Social adaptation of youth in modern conditions. New learning technologies, 35, 259-276.

Khairullin, F. H. (1972). Some social problems of the formation of students and adaptation of students to the university [Monograph], 120.

Halus, O. M. (2004). To live in a new way. Humanities, 2, 46-52. 


\title{
THE STRUCTURAL AND SEMANTIC CHARACTERISTICS OF SINGLE- SYLLABLE IMPERSONAL SENTENCES IN THE CZECH LANGUAGE
}

\author{
Maria Kalenychenko ${ }^{1}$ \\ ${ }^{1}$ Kyiv Taras Shevchenko National University, Kyiv, Ukraine \\ ORCID ID ID: 0000-0001-6222-4083
}

\begin{abstract}
The state of research of monosyllabic, in case of impersonal sentence, the sentence in linguistic of Slav philology has been analysed. The categoric characteristics of lack of personality, the methods and ways of their realization in Czech language have been defined. Structural and Semantic Parameters of Czech impersonal sentences have been investigated. The main patterns of their creation and specificity of their denotative characteristics have been defined as well. The main valency and intential types of Czech impersonal sentences have been established. It is pointed out that the lack of personality as a categoric concept in Czech syntax is realized in five general Slav models with the help of which the specificity of impersonal sentence as one of the most typical variety of Slav sentences of verbal type is represented. A special interest is paid to the interconditionality of the structural-semantic parameters of the qualitative level of the lack of personality. The chosen manner of description of the syntactical units gives the possibility to determine the degree of participation of structure and semantics in the process of formation of such a phenomenon as the impersonal sentences.
\end{abstract}

\section{INTRODUCTION}

In modern Slavic science, the syntactic level remains one of the least studied structural levels of Slavic languages. Many current problems of Slavic syntax, which require a thorough theoretical coverage of a number of issues related both to understanding the intra-syntactic organization of monosyllabic, including impersonal, sentences in Slavic languages, and with the problem of modeling the relevant syntactic units, unfortunately, did not find a synonymous unambiguous solution in the scientific literature.

As the analysis of the scientific literature on the researched problem shows, in modern linguistics sentence models are often analyzed without taking into account their functional characteristics. This approach deprives syntactists of the opportunity to give an in-depth interpretation of many types of Slavic sentences, including impersonal, which are built on the same structural model, but differ in the nature of syntactic functions of components, which has been repeatedly drawn by the attention of a number of researchers.

In linguoslavistics on the basis of different Slavic languages impersonal constructions have been thoroughly studied from their formal and grammatical organization: Andersh (1987), Belichova (1982), Danesh (1997), Vykhovanets (1983). The specificity of the structural parameters of impersonal sentences in Slavic languages was observed mainly within the use of lexical and grammatical means that form the grammatical center of impersonal units, identifying their syntactic labeling, correlation with other monosyllabic communicative units, the scope of different semantic and grammatical types of individual types, as well as the frequency of their use in different styles.

Unfortunately, in modern linguistic Slavic studies there is no unambiguous generally accepted definition of an impersonal sentence, its types and kinds. If some scholars consider impersonal sentences as a meaningless construction with one main member - a predicate, in the form of which the meaning of a person is not expressed and there is no indication of it in this context, then for others impersonal are such monosyllabic sentences in which the action or a state (sign) that arises or exists independently of the performer of the action or the bearer of the sign. 


\section{IMPERSONAL SENTENCE: THE HISTORY OF THE STUDY OF THE GUESTION}

It will be recalled that in the history of the syntax of Slavic languages, the theory of impersonality has come under constant changes. The debatable issue is explained by different views of scientists on the essence of impersonal sentences and the principles of classification.

One of the important problems of the theory was the interaction of impersonal sentences with infinitive monosyllabic sentences. At one time, this question was thoroughly studied by the Russian linguist O. Shakhmatov (Shakhmatov O., 1941) who called infinitive sentences, the main member of which is the infinitive, which evokes the idea of a sign that is combined with a definite (and specifically the second) or indefinite person. Infinitive sentences of this type (subjectless) were contrasted by the scientist with impersonal sentences, existential sentences that convey the combination of sign (in the subject) and being, presence (in the predicate).

In our opinion, giving infinitive sentences signs of impersonality is not sufficiently justified, because they are structurally different from those impersonal, in which the infinitive syntactically depends on other main members. If in verb impersonal sentences the action is indicated as independent of the figure, then in infinitive sentences the performer of the action, ie the active figure is assumed. Infinitive sentences cannot belong to impersonal constructions, because impersonal sentences are characterized not only by simplicity, but also by the fact that they lack a subject.

In scientific works on this problem, Czech linguists have consistently held the view that the main and indivisible component that organizes grammatical connections in an impersonal sentence and expresses its main meaning is the predicate. Minor members of the sentence, the necessity of which is justified in the sentence by the requirements of the predicate arising from its valence, create together with the predicate the main sentence structure or the minimum sentence structure, which qualifies as a relational sentence structure.

The vast majority of researchers rightly believe that the principle of systematization in the study of simple, in particular impersonal, sentences is the result of the method of syntactic-semantic modeling, associated with the establishment of sentence models as abstract syntactic patterns, which can be built separate minimum relatively complete sentences, and therefore the sentence model should include a minimum number of constitutive components.

Researchers believe that at the abstract level of syntactic-semantic modeling the main types of minimal sentence structures are formed from the verb predicate and implementers of its functionalsyntactic positions, which have the character of sentence members (regardless of their morphologicalsyntactic design) (Běličová H., 1982).

Unfortunately, the question of sentence members, which should be included in the minimum sentence structure, is still debatable. Thus, L. Tenier, one of the founders of the linguistic theory of valence, dividing the members of the sentence into actants and sirconstants, included only the first in the structure of the valence model (Tesnie're L.,1959).

A similar view was held by a Slovak syntaxist E. Paulini, who was the first to justify the use of valence theory in Czech and Slovak grammar. E. Paulini on the basis of the analysis of full verbs managed to combine the semantic and formal side of the phenomenon, which he named as the direction of action. The researcher noted that action as a dynamic feature of an object in space does not exist independently, so it is necessary to determine or assign the object to which it is directed, based either on the position of the agent (performer) or a patient, and defines intention as a fact when the verb whether the predicate requires or does not require the expression of an agent or patient of its action (Pauliny E.,1981).

J. Ruzhychka, developing E. Paulini's theory of intention, drew attention to its syntactic aspect, in particular to such points as the discrepancy between the intentional type and sentence structure and the possibility of modifying certain intentional types of verbs. A little later, the Czech syntaxists J. Bauer, M. Greple, and V. Schmilauer, mostly agreeing with the well-founded notions of valence theory and the expediency of its use in linguistic Slavic studies, noted that all obligatory 
components that have constitutive character should be considered valence-bound (Bauer J., Grepl M., 1980; Danesh F.,1997; Schmilauer V.,1969).

The main intentional types of minimal sentence structures are constituted from the verb action and its participants participatory (functional-semantic positions, which have a generalized character of agent, carrier of action or state, patient, adverbializer and qualifier.

These observations also apply to Slavic one-syllable sentences of the verb type, which preserve the nature of the intentional verb action, the ability to open a certain number of functionalsemantic positions to be filled by the corresponding participants.

As noted in linguistic bohemianism, intentional and valence structures correlate with each other, forming complex minimal sentence structures (Andersh J., 1987). The correlation of the components of valence and intentional structures with each other indicates a close connection between the semantic and formal-syntactic organization of the sentence. Accordingly, the violation of the direct correspondence between the components of intentional and valence structures involves modifications of the minimum sentence structures. In Czech syntax, morphological-syntactic implementations of the main valence types of minimal sentence structures and lexical-semantic implementations of the main intentional types of minimal sentence structures are consistently determined at a specific level of syntactic-semantic sentence modeling.

According to Slavic researchers, the establishment of qualitative and quantitative structural characteristics of sentence models in Slavic languages should take into account the morphological and categorical design of the components of minimal sentence structures, as some morphological categories are syntactically relevant and affect the establishment and distinction of models, for example, case category. noun, and others - noun categories of gender and number, verb categories of person, number, gender, type, method, time, etc. - only lead to intra-model changes, without violating the unity of the model.

Used together with prepositions and without them, case forms of nouns are the main means of realization and differentiation of minimal structures and their modifications, and the nominative case as a direct formalizes the left-handed component, and genitive, dative, accusative, instrumental and local as indirect - valid. An important element of the interaction-valence theory of sentence members is the fact that in addition to case and prepositional-case forms, adverbs, adjectives, infinitives and subjunctives of complex sentences can also take part in the design and distinction of structural models of a sentence.

After all, the categorical nature of some statements about the special role of cases in the formation of minimal sentence structures is not always convincing, because the structural model can impose restrictions on specific lexical material that fills its functional and syntactic positions, in particular, for example, the verb promotes the formation of semantic groups one or another case.

Such theoretical generalizations of Czech grammarians are consistent with the opinion of I.R Vykhovanets, who, on the basis of the Ukrainian language, substantiates and defends the thesis that verbs are the main carriers of valence in a sentence, while other carriers of valence - adjectives, adverbs and nouns - acquire valence properties only in connection with the verb, ie due to their movement into the primary predicative position for the verb (Vykhovanets, 1993).

Recall that in Czech and Ukrainian languages, as in other Slavic, semantic-syntactic valence of the predicate means its ability to combine with other words, to have a number of open positions that can or should be filled with units of the corresponding semantic nature, and the ability of the verb to set a certain number of functional-semantic positions for their participants to fill the action at the semantic-syntactic level - its intention, ie the predicate determines the quantitative composition of the components of the sentence and their semantic functions.

Based on the valence-intentional properties of predicate verbs, researchers determine a set of sentence models, or minimal sentence structures (základová větná struktura), which form minimal, but sufficient in structural and informative terms sentences.

According to most Slavic scholars Andersh (1987), Belichova (1982), Danesh (1997), Vykhovanets (1983) it is advisable to distinguish two levels of syntactic-semantic modeling of the 
sentence, including impersonal - abstract and concrete: the first level highlights abstract valence and intentional types of minimal sentence structures, and the second - their specific morphologicalsyntactic and lexical-semantic realizations, ie specific structural and semantic models.

Czech syntactists define an impersonal sentence as a simple syntactic construction with a predicative basis that expresses the action (being), state (sign) of reality regardless of or indirectly relative to the figure, the bearer of the state.

The specificity of impersonal sentences in relation to other monosillabic sentences is defined by researchers of Czech syntax as a way of expressing an action or state as independent of the actor, the bearer of the state, which provides two plans: irrelevance to the subject of action, state and indirect relativity to it.

It is necessary to emphasize the need to take into account the meaning of a person in the predicates of impersonal sentences, because in modern linguistics the category of person is mainly interpreted as a category of predicative type, which is inherent in each sentence of language, based on the ontological nature of speech in general.

\section{THE STRUCTURAL CHARACTERISTICS OF SINGLE- SYLLABLE IMPERSONAL SENTENCES IN THE CZECH LANGUAGE}

In the linguistic literature it is noted that the superficial structure of an impersonal sentence in Slavic languages is determined by two positions - the position of the main member and the position of the secondary member and respectively two members of the sentence - the main and secondary. The existing secondary member of an impersonal sentence extends the predicative core of the sentence or secondary members of the sentence, which are divided into determinant and adverbial secondary members.

Analyzing the corresponding syntactic units in the Ukrainian language, I. R. Vykhovanets affirms that the position of the determinant in impersonal sentences is characterized by the connection with the transformation of a complex sentence by folding one of the predicative parts, and complicated by determinants impersonal sentence is a semantically complecated construction with two or more predicates (Vykhovanets I.R.,1993).

In our opinion, the theoretical generalizations of the famous Ukrainian syntactist are fully consistent with the results of studies of Czech impersonal sentences, in which determinants are combined with the main member of an impersonal sentence by a weak subjunctive connection by means of adjoin, and the position of the determinant is mostly syntactic and analytical adverbs. After all, determinants in Czech, as well as in Ukrainian impersonal sentences do not have a fixed position and can indicate the characteristics of the subject. If there are several determinants, the position of each of them is determined by the proximity or remoteness from the main member of the impersonal sentence.

It is known that the specificity of the subordinate connection in the Slavic languages is reflected by the strong nature of the connection with its typical form-management, which is manifested in the fact that the supporting component by its lexical and grammatical nature requires a dependent component in some form to reveal its content, ie the base component contains the control potential (Danesh F., 1997). Comparison: Zatmělo se jí v očich (L. Ziková: 22); Sklaplo mu v hlavě (K. Mašek:70); Na chvíli jí blesklo mozkem (K.Sezima:160).

The study of impersonal sentences against the background of other Czech monosyllabic structures revealed a strong nature of the subordinate connection in cases where the position of the dependent component is occupied by the accusative case. In this case, the semi-peripheral position is occupied by components that are combined not only with the reference component itself, but also with the words that depend on it. For example, in a sentence Množství jablek, broskví a mukyni strženo bylo se stromi tíhou a dozrálostí (J.Opolský:235) the component se stromů depends on the complex Množství jablek, broskví a mukyní strženo bylo.

In the peripheral position of the dependent component of the phrase there is an instrumental case, which is combined with the base component together with the dependent words in the form of 
weak control. In the sentence Množství jablek, broskví a mukyni strženo bylo se stromů tíhou a dozrálostí component tíhou a dozrálostí depends on the complex Množství jablek, broskví a mukyní strženo bylo se stromů.

The implementation of a weak subordinate connection in word-combinations with a projection on the structure of the Czech impersonal sentence occurs by means of concord, the choice of which is determined by morphological factors: komu se dostane čeho od koho. Comparison: Vždyt' se vám dostalo výhodného pozadí (F.Šrámek:288). This phenomenon can be traced in other Slavic languages when the expressed adjective with syntactic forms of the genus, number and case of the adjective dependent member of the word-combination is combined with the base noun, and the forms of the genus, number and case of the adjective are determined by the forms of the genus, number and case of the base noun.

In Czech impersonal units, in addition to the main member, secondary members of the sentence (determinant and adverbial secondary member) in the positional structure of the sentence are also positions of the supporting member and indirect secondary member of the sentence, which do not change the qualitative structure of the impersonal sentence, changing it only quantitatively. The supporting members in the structure of an impersonal sentence are connected by a coherent connection, which does not make qualitative changes, but only spreads the sentence through the introduction of new members, homogeneous in form and grammar.

This feature of the structure of Czech impersonal sentences, obviously, can be qualified as common Slavic, as it can be traced in East Slavic languages, in particular in Ukrainian, when the indirect subjunctive is characterized by inequality of its combined sentence members, one of which (dependent) is subordinate to the basic, on the one hand, and through the mediation of the reference correlates with the predicative core of the impersonal sentence. The comparison is Czech Bylo mu uloženo vyplatit oslovenému dlůh, vlastně jen dvacet korun (V.Dyk:262).

At the formal-grammatical level, the predicate in Czech impersonal sentences can be complicated by phase verbs. The predicative base necessarily includes a conjugative or auxiliary verb, although in determining the categorical affiliation of the main predicative member, predicative bases with proper impersonal and impersonal impersonal verbs, predicative adverbs, predicative forms on -no, -to, combinations of modal components with infinitive.

According to structural features, impersonal sentences of the Czech language are divided into simple, complex and compound predicative units. The main structural types of Czech impersonal sentences presented in the article take into account the valence of verb predicates, in particular those functional load of which can be traced both at the level of frequency of constructions in the analyzed texts and at the level of intentional parameters of predicative units.

Therefore, the structural model of the Czech impersonal sentence, in addition to the core, includes all the semantic components necessary for the realization of the communicative completeness of a particular impersonal unit without taking into account the species differentiation of predicates, because not always coincidence of structural characteristics.

At a specific level of syntactic-semantic modeling of a sentence, morphological-syntactic realizations of the main valence types of minimal sentence structures, ie structural models of a sentence, are determined. Determination of structural models of sentences is carried out taking into account the peculiarities of morphological and categorical design of the components of minimal sentence structures. The fact is taken into account that different morphological categories take part in the design of the components of minimal sentence structures, some of which are syntactically relevant, and others only lead to intramodel changes without violating the unity of the model.

Basic elementary impersonal predicative units in the Czech language are constructions with the main member expressed by an impersonal verb or a personal verb used in an impersonal form. Such structures in which the verb predicate is self-sufficient, ie does not open any additional functional-syntactic positions, in Czech linguistics are called structures with valence-free predicates (struktury s predikáty bezvalečními). One of the characteristic structures of impersonal predicative units in the Czech language is the impersonal sentences (12.5\% of the total number of analyzed constructions). 
Such sentences have a stable and at the same time limited morphological expression, because the function of the main member in them is performed only by an impersonal verb - without the particle se or with this particle.

In the Czech language, impersonal verbs are characterized by a narrow paradigm in terms of modal and temporal characteristics: Svitá. Dosud ještě nesvitalo. Musí už svítat etc; in species oppositions: sněži - zasněží therefore the number of impersonal verbs without the particle se is limited (sněžit, svitat, pršet etc.). This type of one-syllable sentences in the Czech language is the only sentence structure of the impersonal type, based on the avalence of the verb (structural model Vf imp); predicates here are usually verbs that call atmospheric phenomena Mrzlo, až praštělo; Venku sněži; To se práší!; Zavři, táhne!

Such predicates do not require any direct action or intervention by any object. If we are talking about the subject, then it is mainly a carrier of inertial action, although from the standpoint of valence bohemians describe such structures as twofold. Comparison: Uhodilo - Uhodil blesk. Zatahuje se Obloha se zatahuje. Rather, here you can predict the circumstance of the place, comparison: Odpoledne prši (Mája Z.); Smrákalo se, mžilo (B. Hrabal); Už svítalo (K. Sezima). Venku přestáválo pršet (O. Bočková).

In verbs denoting the motion of matter, alternatively, the possible spread of the structure due to the circumstances of the place, clarifying \&quot; kde \& quot: Prši - Venku prši - Do stanu prší Na horách fouká - Od hor fouká. Tady práši - Práśí se sem okny. Important for the theory of impersonal sentence in the Czech language are the views on the problem of Czech grammarians F. Danes and Z. Glavsa, who believe that the use of circumstances in such a simple sentence model can not be qualified as a normative phenomenon. Therefore, such cases of using the circumstance in the actual impersonal sentences, in our opinion, are obligatory, because in the Czech literary language Táhne used only in combination Tady / pode dveře táhne etc.

The second group of impersonal sentences in the Czech language is formed by impersonal constructions built on the structural model $\mathrm{V}$ fimp refl, where the formative element is inverse verbs without constructive determinants. Unlike the first group of sentences, built in the Czech language on the structural model Vfimp, which is quantitatively limited, impersonal sentences with the particle se are widely represented in all Slavic languages, although the range of their semantic meanings is not wide mostly an indication of weather, change of day, the value of success or failure and the state of beings, for example: Zetmélo se (R.Jesenská); Podařilo se (K.Sezima); Neozvalo se (V.Dyk); Myslilo se (O.Theer); Zdálo se (K. Mašek); Stalo se (J. Hilbert); Jelo se (J. Durych); Tvrdilo se (K.Sezima); Pílo se a jedlo (J. Durych); Podařilo se! (J. Opolský); Hrálo se (V. Dyk); Filmuje se (K. Čapek). Such Czech impersonal sentences can be transformed into two-syllable constructions in which the verb-predicate is used without the particle se, losing the meaning of the generalized action, comparison: O tom se ještě dodnes vypravuje - O tom ještě dodnes vypravují - Lidé/Všichni o tom ještě dodnes vypravují. The possibility of such a transformation is explained by the fact that in the Czech language the reflexive form can be formed from almost any verb, including modal verbs moci, mit, smět, musit/muset.

Sentences in which the verb predicate reveals the positions of the object, the adverb, or both minor members are qualified in bohemianism as structures with valence predicates (struktury s predikáty valečnimi). They form a fairly large group of constructions in the Czech language $(50.6 \%$ of the total number of analyzed sentences) with verb predicates that express physical feelings, experiences, moods or mental state of a person and are represented by monovalent or divalent structural models. Such predicative units refer to an action when a person does not act as its direct performer, but rather experiences the action, and the fact of connection with a person of a certain event, mood or state always corresponds to one of the positions of the valence field, but never the position of the subject.

In the structural model of the impersonal sentence of the Czech language Vfimp - Adv the constitutive component is an adverb that has the value of the localizer of action $(5.6 \%$ of the total number of analyzed constructions). Such impersonal sentences indicate the localization of the action in a particular object or place. Accordingly, there are two versions of the model - ADV "kde", for example: Huči $v$ komině (F. Šrámek); Straší v zámku (O. Theer); V podrostech harašilo (K.Sezima) and ADV"kam”, for example: Nateklo do síně (V.Dyk); Zaklepano slabě na dveře (J.Hilbert); Uhodilo do stodoly (V.Dyk). 
In the Czech language, the syntactic noun in the form of the genitive case is a mandatory component of the model is Vfimp - Sg (3.8\% of the total number of analyzed constructions), for example: Stačilo však jenom trochu sebevlády (F. Šrámek); Nezbývalo nic jiného než čekat (I.Klíma); Připadalo sněhu ale pozdéji se vyjasnilo (J. Durych). Researchers note that the number of Czech verbs that can act as an impersonal predicate of constructions with a genitive case is limited. In fact, these are verbs that have the meaning of increasing or decreasing the number, volume or size of something, such as ubývat, pribývat, napadat, pripadat. As our observations show, the meaning of complete, absolute absence can be expressed by specialized morphological means, in particular the use of a noun with a diminutive suffix in the form of the genitive case, comparison: Nebilo ani človička (I. Klíma).

It is known that the analyzed type of impersonal sentences can be correlated with the corresponding Czech two-syllable constructions, comparison: Připadalo sněhu - Sníh pripadal. The difference between these sentences is that impersonal construction takes as a special reading connected with more uncertainty, generalization of the concept which will be able to be a subject.

According to the structural model Vf imp refl - Sd in the Czech language a significant number of sentences is formed (16.9\% of the total number of analyzed constructions), for example: Mně se stalo! (J. Hilbert); Zdálo se mu (J. Hilbert); Nelíbilo se mi (J. Matějka); Připadalo jí (Jan z Wojkowiez); Připadalo $m i$ (O. Theer). The object in the form of the dative case, used in an impersonal sentence that conveys the action or state of the object (person), is close to the nominal subject in two-part constructions, comparison: Rodiče mu zemřeli - (Jeho) rodiče zemřeli; Ztratilse mi pes - Ztratil se můj pes. In cases where the predicate expresses not physical but mental actions, the semantic difference between one-syllable impersonal and two-syllable personal sentences is minimal, the comparison: Spát se mi nechtělo-Nechtěl jsem spát; Nechtělo se mi věřit-Nechtěl jsem věrit; Chtělo se jí střašlivé zasmát-Chtěla střašlivé zasmát.

A constitutive component of another structural model Vf imp - Sa is the accusative case of a noun or pronoun in state predicates $(6.2 \%$ of the total number of analyzed constructions. Such a model forms sentences that express the physical or mental state of a person. For example: Mrazí ho (K. Sezima); Štvalo mne (O. Theer); Mrzelo mě, že s naší chystané cesty sešlo (I. Klíma); Mne kručelo (O. Bočková).

The accusative case, in contrast to the genitive, dative and instrumental cases, Czech syntaxists qualify as a peripheral morphological means of expression of the subject syntax, noting that the semantic variants of the accusative case can be replaced by syntagmatic, which, in turn, does not clearly define the place of accusative case on the axis of personality / impersonality. Therefore, the only function of the accusative case as one of the two object actants is the actant function, which is somehow caused by external action.

The study of the specifics of divalent structures of impersonal sentences in modern Slavic works on syntax is presented using a systematic approach to the study of linguistic phenomena, which involves the analysis of relevant syntactic units both at the level of language and at the level of speech. This allows us to identify models by which impersonal syntactic constructions are formed, anticipating their structuralsemantic interaction. Thus, in the Czech language divalent structures are represented by structural models Vf imp - Sd - Adv; Vf imp refl - Sd - AdvQual; Vf imp - Sa - Adv; Vf imp - Si - Adv; Vf imp - Sa - Si organizational center of which is predicate syntaxes with the semantics of the state, which, according to researchers, can indicate the proper-state and the improper-state.

According to our observations, in quantitative equivalent, divalent structures account for $18.1 \%$ of the total number of analyzed structures, and predicates that convey the value of physical, physiological and mental state of a man, in addition to the position of the carrier of this state open the position of the state object, physiological or mental state, and the position of the valence field coincides with the object of the place. Comparison: V hlavě se mu zamžilo (H. Malířová); Hrobnika bolelo skoro všude (B. Ríha); V hlavě mu hučelo rychlými a bolestnými tepy (K.Čapek).

Researchers note that in the Czech language there is a large group of impersonal sentences (according to our observations $28.1 \%$ of the total number of analyzed constructions), in which the verb být can act as a formal grammatical predicate. Like any other verb, the verb být in such sentences is a carrier of grammatical categories, but is not a real, "responsible" center of the sentence in the literal sense of the word, because the function of the semantic predicate is performed by the whole complex být + 
predicate, although in Czech the verb být does not always act only in the function of the verb-connection (terminologically - spona) as we have in impersonal constructions, and as stated in the syntactic studies of Czech linguists (Havránek B., Jedlička A., 1981). Comparison: Je student - Není student i Je mi lito Není mi líto.

Sentences with the predicative center být + predicate in Slavic languages usually indicate static meanings. Thus, among the studied Czech impersonal sentences, sentences with the predicative center být + predicate indicate the characteristics of atmospheric phenomena: Bylo dusno, žrejmě na déśt' (I. Klíma); Venku pršselo a bylo dost chladno (P.Tigrid); Tady bylo spíš vlhko a dopoledne pršselo (H.Malírová); express a subjective-objective assessment of the situation or environment: Je pěkně (K. Mašek); Bylo tak ticho v domě a venku (Mája Z.); Zase bylo ticho (Bočková O.) or are used to indicate the physical or mental state of a person: Není vám nevolno? (K. Žák); Ráno jí bylo hưre (K. Sezima); Jeli vámteplo, odložte si kabát (H. Malířová).Among the analyzed impersonal sentences of the Czech language with a compound predicative base, predicative units with the main member-verb in the form of an infinitive and the auxiliary verb být most often function, for example: Bylo mi často mírniti jeho prudký hněv (V.Vančura); Bylo cítit, že země chvěje (K.Sezima); Bylo slyšet výbuchy (I.Klíma); Nebylo těžké je nalézti (F.Šrámek); adjective forms on -no, -to together with the auxiliary verb být, for example: Pod stromy už plničko listů napadáno (Maja Z.); Bylo mi dovoleno býti hněvivým (V.Vančura); Mnoho spisovatelu bylo umlčeno a pronásledováno (P.Tigrid); Zaklepano slabě na dveře (J.Hilbert); adverbs together with the auxiliary verb být, for example: Tenkráte mu bylo úzko (P. Kles); A tady je dusno (I. Klíma); Nebylo nám volno v pařižském vzduchu (M. Jiránek); Ale bylo mu v ní úzko a smutno (H.Malírová); infinitive forms together with modal verbs and auxiliary verb být, for example: Kéž by bylo možno zapomenuti (Jiři K. ze Lvovic); Jak bylo možno jíti v náhlém šeru (V. Dyk); K vưli rodičů už bylo možno oko primhouřit (K. Sezima).

Our observations on the structural characteristics of single- syllable impersonal sentences in the Czech language allowed us to identify the main features that determine this structural type of sentence among other single- syllable and the possibility of its modification. The most important structural feature of impersonal sentences in the Czech language is the presence of only one main predicative component, which subordinates the other components, if they are in the sentence, for example: Zdálo se (B. Říha:144); Prší (H. Pavlovská:40); Zetmělo se (R. Jesenská:53); Sněži (M. Majerová:61); Hřimalo (V.Vančura:102); Tmělo se a tmélo (K.Sezima:127). Unlike other types of one-syllable sentences, such an impersonal structural-grammatical center does not allow the introduction of the second polar component into the structural scheme.

The second very important differentiating feature of an impersonal sentence in the Czech language is the transposition of a potential subject in addition, most often in the form of the dative case, for example: Ulevilo se mi (R.Jesenská:57); Bylo jí souzeno se státi světicí (J. K. zeLvovic:13); Zatmělo se ji vočích (L. Ziková:22); or generic, for example: Hrobníka bolelo skoro všude (B.Říha:75); Zkratek se užívalo nejčastěji u názvi̊ spolků (D.Šlosar:97); or a finder, for example: Ráno mě boli v břiše (B.Řiha:61); Mrzelo mě ... (I.Klíma:212); or the inventive one, for example: Vonélo tu pochybem větrů (M.Majerová:100); Dýchalo tu zmarem (I.Klíma: 76); or local, for example: V následných procesech bylo odsouzeno přes 600 lidí (P.Tigrid:54); Ve všech třech tábořech se umíralo snadno a rychle (B.Ŕíha:14). In such constructions, the main member of an impersonal sentence does not depend on other members of the sentence and forms the structural basis of the sentence without their help. 


\section{THE SEMANTIC CHARACTERISTICS OF SINGLE- SYLLABLE IMPERSONAL SENTENCES IN THE CZECH LANGUAGE}

In Czech linguistics, the problems of semantic syntax were studied by J.F. Andersch, J. Bauer, G. Belichova, F. Danesh, M., M. Grepl and other linguists, but despite the great list of researchers of this problem, in the reviewed works the synonymous of syntactists views is not traced. Moreover, almost each of them in their own way considered the issue of categorical concepts of semantic syntax using their own methodology of syntactic semantics, given the complex nature of sentence content and distinguishing three levels of representation - denotative, logical-semantic and linguisticsemantic.

If scientists correlate the denotative level of a sentence with real situations, ie real objects and relations between them, logical-semantic - with logical structures, concepts and relations between them, then linguistic-semantic is connected with semantic-syntactic structures, ie lexical components and relations between them.

The principles of research of syntactic semantics in the presented theories allowed to establish certain hierarchical relations, because the denotative level is the basis for the logical-semantic, on which, in turn, the linguistic-semantic is based. It is within the latter that the semantic structure of a sentence is established in close connection with its formal-syntactic organization.

In Ukrainian linguistics, the semantic approach to the study of impersonal sentences, taking into account both semantic and structural features, was initiated by N. M. Arvat. The researcher defines the semantic structure of a sentence as a semantic complex organized on a predicative basis, which is the result of the interaction of semantic components and reflects the relationship of the elements of reality. According to her, sentence semantics is realized in two ways: structural- semantic model, which reflects the morphological expression of sentence components and their semantic function, and semantic model, which is reproduced only by the component composition of the semantic structure of the sentence (Arvat N. M., 1976). Unfortunately, the well-known syntaxist ignored the complex relationship between the semantic model of a sentence and its formalgrammatical expression, as well as the issue of a complex impersonal sentence.

An original approach to the study of semantic characteristics of sentence units was proposed by Ukrainian syntaxist I. R. Vykhovanets, who studies the implementation of semantics in the formalgrammatical structure of a sentence based on the fact that a sentence is a multidimensional unit and should be analyzed taking into account its specifics. The scientist distinguishes four tiers in the sentence structure: formal-grammatical, semantic-syntactic, proper-semantic and propercommunicative, which, being in different relationships, have different relations to the content and form of the sentence (Vykhovanets I.R., 1993).

At the level of the actual semantic structure of the sentence, which conveys

the logical structure of thought, the units are semantics, in particular the semantic predicate and dependent arguments. The researcher argues that it is the predicate that determines the number of non-predicate signs and together with them forms an elementary sentence, because the nature of the predicate, its semantic quality predicts what arguments will accompany it (Vykhovanets I.R., 1993).

The lack of unambiguous interpretation of the term "impersonal sentences" in Slavic science, in our opinion, is primarily due to the fact that on the categorical axis "personality / impersonality" intersect with "subjectivity / impersonality", "monosyllabic/disyllabic", "activity / passivity" (Vykhovanets I.R., Horodenska K.G., Rusanivsky B.M., 1983). The imperfection of the classifications made according to the degree of personality (personal, generalized-personal, indefinite-personal, impersonal) or structure (monosyllable, disyllable sentences) is noted by J.F. Andersh (Andersh J.f., 1987).

The most significant of these shortcomings, in his opinion, is the inconsistency of formal features with semantic opposition, as a result of which heterogeneous phenomena are united and homogeneous are separated (Andersh J.f.,1987). Therefore, an important result of our study is the 
description of all possible projections of the universal category of personality / impersonality at the syntactic level of language, the study of its interaction and relationship with syntactic categories "subjectivity / subjectiveness", "monosyllabic / disyllabic", "activity / passivity" and etc.

Our study actively uses the theory of semantic syntax of Czech linguists (works of P. Adamets, G. Belichova, F. Danes, R. Mrazek), who believe that the semantic structure of a sentence should take into account the meaning of the predicate and its semantic-syntactic valence, which predicts qualitative and quantitative composition of left and right syntaxes. This approach made it possible to determine the semantic parameters of structures with proper impersonal verbs as predicates. It is noted that the quantitative limitation of predicates in the actual impersonal constructions of the Czech language is due to the specifics of the denotative characteristics of the sentence, ie the range of natural phenomena that, we think are outside the subject, is quite limited and has no tendency to spread.

Since the verbs-predicates of the impersonal group of sentences in the Czech language, as in most Slavic, are transitive, often monovalent, the semantic structure involves only one direct object, in fact - a passive subject, in particular, the semantics of a possible sub in such sentences is identical to the semantics of the predicate. Therefore, the subject in such structures is not only not perceived, but also perceived as superfluous, although semantically associated with the predicate and often has a common root with it. Comparison: Zetmělo se; Tmělo se a tmělo; Stmívá se // Tma se stmívá; Nastává tma. Dosud se nesvítilo // Světlo se nesvitilo. Sněží // Pádá sníh. Leje // Lijak leje.

The analyzed group of impersonal sentences in the Czech language mainly includes constructions that convey the names of natural phenomena, the state of the environment $(8.1 \%$ of the total number of analyzed constructions). Therefore, the predicates that form the basis of these constructions are of appropriate importance, e.g: Pršet; Šeřit; Mokvat; Smrákat se; Mžit; Vyjasnit se; Oteplit se; Vanout; Snězit. The class of actually impersonal in the Czech language also partially includes constructions that denote the state of man, being (general meaning - a painful condition) (7.5\% of the total number of analyzed constructions). In such sentences, the degree of subjectivity is slightly lower than in the previous type.

This is due to the fact that in the structure of the actual impersonal constructions that indicate the state of man, being, there is an indication of a person expressed by a specific name, which corresponds to the passive subject. The syncretism, integrity, inarticulateness of the subject-predicate semantics of such constructions come to the fore. For example: Třáslo se jeho (J. Hilbert); Chytlo mne a už nepustilo (J. Matělka); Mně kručelo v žaludku (O. Bočková); Štvalo mne z jedněch snů do druhých, bez ustání, bez milosrdenství (O.Theer).

Among the Czech impersonal constructions, the predicative core of which consists of personal verbs that have acquired impersonality due to linguistic actualization, it is worth noting sentences that reflect the state of nature, environment, nature of the situation, as well as sentences that reflect the state of man, being. In particular, this group includes impersonal sentences in which the predicative nucleus is associated with verbs of thermoregulatory or olfactory semantics: vonět, smrdit, táhnout, foukat, vanout etc. ( $8.1 \%$ of all analyzed impersonal sentences).

In one-syllable predicative constructions, such personal verbs are used in the sense of impersonal and function in the "impersonal shell" - in the third person of singular of the present tense or in the form of the singular of the middle gender of the past tense. Because the semantics of these verbs does not foresee necessary impersonality, so obligate distributors are used to convey the impersonal meaning. Example: V kuchyni vonělo kávou (H.Malířová); V jídelně vonělo jablky (J.Hilbert); Vonělo tu velikonočním mazancem, ruměným a křǐzem pukajícím (M.Majerová).

It should be noted that this semantic specificity of Czech predicate verbs of this group, obviously, gives grounds for the formation on the basis of the same verbs used in the impersonal sense, metaphorical clichés such as Vane (dychá) starobylostí; Tady smrdí kriminálem. for example: Ve světnici bylo teplo, vonělo tu úklidem (M. Majerová); Tahlo mne kženám (O.Theer); Tahlo tam jakousi ztuchlinou bytu dlouho neuživaného a skoro odemřelého (K.Čapek). The structure of these constructions, which conveys the meaning of generalization, objectivity and involuntaryness, allows without expressing additional structural elements to express the necessary emotional and evaluative 
meaning in the form of a statement of fact, which, in our opinion, only reinforces the metaphorical nature of such clichés.

The next semantic subtype of impersonal sentences in the Czech language is formed by constructions that denote the state, the situation, which arose, as a rule, as a result of a natural disaster and led to negative, destructive consequences (6.3\% of all analyzed impersonal sentences). In this model, the constructive component is a circumstance that has the value of the localizer of action, for example: V podrostech harašilo (K.Sezima); Celé odpoledne se z ordinace jen kouřilo (B. Ř́ha). The predicative core of such sentences consists of verbs (or verb forms on - no, - to) of the corresponding semantics: uhodit, zanést, zasypat, vytlačit, hučet, prasknout, etc.

In other cases, there are impersonal constructions that indicate the state of man, being $(46.3 \%$ of all analyzed impersonal sentences). Example: Všem bylo trapno (H.Malírová); Bylo mi mdlo (O.Theer); Sklaplo mu v hlavě (K.Mašek); Chytlo mne a už nepustilo (K. Sezima). The constructions that are part of this group, mainly indicate the state of the creature as caused from the outside, regardless of its will. In this case, the subject with the meaning of perception of a state is expressed by a syntax in the form of the dative case, it is removed from the position of the nominative, which is associated with the meaning of the active figure.

A separate group is formed by impersonal sentences, the predicative core of which consists of modal verbs that characterize the situational behavior of man $(15.6 \%$ of all analyzed impersonal sentences). In the Czech language, as in other Slavic languages, the modal characteristics of the predicate are actually determined by the modal features of the verb. The imposition of an additional modal characteristic on the predicate of a sentence excludes the possibility of its imposition on a logical predicate, which can be traced when dividing a sentence into a subject and a rhyme.

For impersonal sentences of this group, a component with the meaning of a passive subject is obligatory, their semantics are completely connected with the characteristics of a person, a living being. The peculiarity of these impersonal sentences is that they convey a person attitude to any action, state or situation, which are not determined by the person himself, but by external causes and circumstances that do not depend on the will of the person. Example: $K$ vuili rodičů už bylo možno oko přimhouřit (K.Sezima); Je nutno s tím zacházet opatrně (L.Vaculík); Chtělo se jí najednou střašlivé se zasmát (F.Šrámek); Na to se mu sí brát ohled (L.Vaculík).

Negative impersonal constructions (1.3\% of the total number of analyzed constructions) deserve special attention. Example: Po ráně nezůstalo ani památky (V.Dyk); Ale myslivci se také lépe nevedlo (B.Hrabal); Nestalo ani za řeč (K. Sezima).

It is established that in Czech impersonal constructions with a genitive negative predicate is expressed mainly by a personal existential verb in the forms of present, past or future tense, as well as verbs such as nezbýt, nezůstat, neminout, nechybět and some others, for example: Nebylo však vyloučeno (I. Klíma); Ale na tom nedalo se mnoho ménit (V.Dyk). Each form of the verb paradigm can be used both as an independent sentence and as a component of a complex sentence.

Negative one-syllable impersonal sentences in the Czech language are semantically correlated with the corresponding two-syllable sentences, which function in the artistic style quite actively. When transforming such one-syllable sentences of the Czech language into two-syllables, the indirect case (genitive or dative) is replaced by a noun. The noun component in the genitive case can be qualified as a genitive partitive or a genitive negative.

As the analysis of the scientific literature on the researched question shows in Slavic languages the dependence of semantic-syntactic characteristics of a single-sentence on the possibilities of transformation of its structural units is traced. The selection of the semantic-syntactic tier of the sentence and its structural components - syntax gives linguistic science an additional opportunity to establish the specifics of the grammatical structure of any (in our case - Czech) language against the background of universal logical-semantic structures. Syntaxemes are the connecting link between semantems and members of a sentence and are the main semantic-syntactic projection of the corresponding language on its own semantic and formal-grammatical structure. 


\section{CONCLUSIONS}

Thus, the universal category "personality / impersonality"; in the Czech language is based on the reflection of the extralinguistic semantic construct "absence or elimination of the subject (object, person) of action or state". The absence of the subject or its elimination is qualified as heterogeneous phenomena that arise at the conceptual level as a result of interaction of different tiers of the language system and affect the functional perspective and semantic-grammatical status of a single sentence as a syntactic unit.

In the conditions of impersonal functioning of personal verbs in the Czech language there is an implicit expression of the semantic subject, i.e. its successive reduction is traced both on formalgrammatical, and on semantic-syntactic levels of the sentence, and, consequently, impersonal use of personal verbs. units that differ from the relative two-syllable personal indirect expression or lack of expression, the implicitness of the subjective component.

The semantic structure of the predicative core of an impersonal sentence in the Czech language is determined by the qualitative level of impersonality: such constructions with the meaning of absence, impossibility of the person causing the action form a group of so-called impersonal constructions, for example: Tmělo se a tmělo; Stmívá se; Smrákalo se a mžilo, and constructions with the meaning of removing a person create a group of sentences, the impersonality of which arose as a result of linguistic actualization, the realization of linguistic semantics, e.g: Mžiklo mi hlavou. If the first group of constructions is quantitatively limited, and the units that are part of it can be listed with some reliability, the second group of sentences is an open value that can be supplemented taking into account the morphological features of the Czech language.

The transition from the personal structure of the sentence to the impersonal in the Czech language occurs: 1) under the condition of vague perception and differentiation of the actor and action as a result of the total impression of the action and the actor - stmívá se; 2) in cases where the figure himself is an instrument of some force - uhodilo (bleskem); 3) in cases when instead of the figure the situation suggests what was not expressed in speech - hoři, zvoní; 4) in cases when different modal verbs with the meaning of necessity, coercion form an impersonal sentence, which is aimed at everyone and no one - Je nutno s tím zacházet opatrně; 5) in cases where there is a need to assess the internal psychological state - V̌sem bylo trapno.

The predicative base of impersonal sentences in the Czech language necessarily includes a full or auxiliary verb, which indicate the categorical characteristics of impersonality; structural and semantic features of impersonal units are most noticeable in sentences with proper and impersonal impersonal verbs, predicative adverbs, adjective forms on -no, -to and others.

\section{REFERENCES}

Andersh J.f. (1987). Typology of simple verb sentences in the Czech language in comparison with Ukrainian.

Arvat N. M. (1976). Component analysis of the semantic structure of a simple sentence.

Bauer J., Grepl M. (1980). Composition of standart Czech.

Belichova G. (1982). Semantic structure of the sentence and case category.

Danesh F. (1997) Czech language at the turn of the millennium.

Diachok, N., Chernukha, N., Tokaruk, L., Udovenko, I., Petrova, M. 2020. Practical-oriented concept as a principle of professional education of the future professionals. International Journal of Higher Education, Vol. 9, No. 4, August 2020, pp.272-282, https://doi.org/10.5430/ijhe.v9n4p272

Ivanchuk, S., Voznik, A., Dronova, O., Girenko, N., Arsova, D. (2020). Preparation of Future Preschool Education Specialists for the Use of Modern Educational Technologies. International Journal of Higher Education, Vol. 9, No. 5, August 2020, pp.28-35, https://doi.org/10.5430/ijhe.v9n5P28 
Galskova N. D. \& Gez N.I. (2006). Teoriia obucheniia inostrannym iazykam. Lingvodidaktika i metodika [Theory of teaching foreign languages. Linguodidactics and methods]. M.: Izdatelskii tsentr «Akademiia».

Grammar of the Czech language. Syntax (1987).

Havranek B., Jedlichka A. (1981). Grammar of the Czech language.

Pauliny E. (1981). Slovak grammar. Description of the language system.

Schmilauer W. (1969). Novočeská skladba.

Shakhmatov O. (1941). Essay on the modern Russian literary ladguage.

Tesnie're L. (1959). E'le'ments de Syntaxe Structurale.

Vykhovanets I.R., Horodenska K.G., Rusanivsky B.M. (1983). Semantic-syntactic structure of the sentence.

Vykhovanets I.R. (1993). Grammar of the Ukrainian language. Syntax. 


\title{
SOCIAL CAPITAL: VECTORS OF DEVELOPMENT OF BEHAVIORAL ECONOMICS
}

Collective monograph

Copying of content is not permitted except for personal and internal use, to the extent permitted by national copyright law, or under the terms of a CC BY-NC 4.0 License.

\author{
English \\ First Edition \\ free publication \\ Editor: Prof. Dr. Mariana Petrova, DSc \\ Pages: 184 \\ Format: $60 x 84 / 8$
}

Publisher: ACCESS Press Publishing house, Bulgaria, 2021

32 Alexander Burmov Str., 5000 Veliko Tarnovo, Bulgaria

Email: office@access-bg.org

http://www.access-bg.org

\section{ISBN 978-619-91511-4-3}

The publisher remains neutral with regard to jurisdictional claims in published materials and institutional affiliations. Neither the publisher nor the authors or the editors give a warranty, express or implied, with respect to the material contained herein or for any errors or omissions that may have been made.

Veliko Tarnovo, Bulgaria, 2021 